\title{
A REAPPRAISAL OF NEOTROPICAL VANILLA. WITH A NOTE ON TAXONOMIC INFLATION AND THE IMPORTANCE OF ALPHA TAXONOMY IN BIOLOGICAL STUDIES
}

\author{
Adam P. Karremans ${ }^{1,2,6}$, Isler F. Chinchilla ${ }^{1,3}$, Gustavo Rojas-Alvarado, \\ Marco Cedeño-Fonseca ${ }^{1,3}$, Alexander Damián ${ }^{4} \&$ Guillaume Léotard ${ }^{5}$ \\ ${ }^{1}$ Lankester Botanical Garden, University of Costa Rica. P.O. Box 302-7050 Cartago, Costa Rica \\ ${ }^{2}$ Naturalis Biodiversity Center, Endless Forms Group, Leiden, The Netherlands \\ ${ }^{3}$ Herbario Luis Fournier Origgi (USJ), Universidad de Costa Rica, Costa Rica \\ ${ }^{4}$ Facultad de Ciencias Ambientales. Universidad Científica del Sur, Lima, Peru \\ ${ }^{5}$ PK1, chemin du mont Paramana, 97351 Matoury, French Guiana \\ ${ }^{6}$ Author for correspondence: adam.karremans@ucr.ac.cr
}

\begin{abstract}
Despite the long-standing cultural importance and botanical interest in Vanilla, many taxa belonging to the genus remain poorly understood. Vanilla species generally have broad geographical and ecological distributions. Most species are found in multiple countries, while local endemics are rare. Many names proposed in the eighteen and nineteenth centuries remain cryptic and unused despite having priority over more recently proposed names. Relatively few Vanilla species have been well-documented, both locally and across their entire distribution range, while a significant portion of novelties have been proposed on the basis of very few specimens that are compared only with local floras. After careful inspection of the type materials, living plants, botanical illustrations, photographs and hundreds of additional herbarium specimens of Vanilla we tentatively recognize 62 species for the Neotropics. The taxonomy of Vanilla columbiana, $V$. hartii, V. inodora, V. karen-christianae, V. marowynensis, V. mexicana, V. odorata, V. phaeantha, V. planifolia, and $V$. pompona is revised. An updated typification, description, photographs, illustrations, list of studied specimens, distribution map, extent of occurrence and discussion is provided for each of the ten species. Taxonomic proposals include 28 new synonyms, 14 lectotypifications, and one neotypification. We stress on the importance of alpha-taxonomy for biological studies, emphasizing on the detrimental effects of taxonomic inflation and incorrect species determination on the inference of speciation rates, the understanding of biogeographical patterns, the correct estimation of ecological niches, seed dispersal studies, phylogenetic and genomic studies, and the assessments of conservation priorities, among others. Finally, the recently proposed genus Miguelia is placed under the synonymy of Vanilla.

Key Words: Conservation, distribution, Miguelia, typification, Vanilla columbiana, V. hartii, V. inodora, V. karen-christianae, V. marowynensis, V. mexicana, V. odorata, V. phaeantha, V. planifolia, V. pompona
\end{abstract}

Introduction. The pantropical genus Vanilla Plumier ex Miller is probably the most well-known and widely appreciated of all orchids thanks to the famous flavoring that is found in its fruits (Bouétard et al. 2010). Vanilla species, nonetheless, are taxonomically challenging due to the sparsity and poor state of flower material (Lubinsky et al. 2008, Soto Arenas \& Dressler 2010). In the first monograph of the genus, Rolfe (1896) recognized 52 Vanilla species worldwide. Portères (1954) increased the number to 110 accepted species, while more modern treatments report lower numbers. Especially noteworthy are the accounts of Soto Arenas \& Cribb (2010) and Cameron (2011), who estimate that the genus includes 106 and 101 species, respectively. However, many additional novelties have been proposed since, elevating the number of Vanilla species to almost 140 .

Despite the long-standing cultural importance and botanical interest in the genus, a disproportionately large number of Vanilla species have been recognized and proposed in recent years. Only fifty species had been described in the $18^{\text {th }}$ and $19^{\text {th }}$ centuries, and 
a similar number of species was added in the $20^{\text {th }}$ century. In the first 250 years of existence of the genus about 100 different Vanilla species were recognized in the world's Tropics. In contrast, interest in Vanilla has seen a dramatic renewal in the last decade (i.e. since the publication of the studies of the late Miguel Soto Arenas). In the last ten years, 32 Vanilla species have been proposed as novelties, of which 26 are Neotropical. These figures are not suspicious per se, as species discovery in highly diverse orchid groups occurring in Tropical countries has increased in recent years. The vast majority of species belonging to very large genera (i.e. Bulbophyllum Thouars, Epidendrum L., Lepanthes Sw. and Stelis Sw.) have been described in relatively recent times (Karremans \& Davin 2017). However, Vanilla differs from those genera in four key aspects: a) Vanilla is a highly valued crop and has historically been given much attention botanically, horticulturally and commercially; b) Vanilla species are very conspicuous, they have massive plants with large showy flowers; c) Vanilla species are found in the lowlands, augmenting connectivity and reducing isolation; d) And most importantly, Vanilla belongs to one of the oldest orchid lineages, which have conserved an extremely slow diversification rate (Givnish et al. 2015). Contrary to many other Neotropical orchid groups, the vast majority of Vanilla species are relatively old and broadly distributed, mostly not restricted to a single country or area. Cases of narrow endemism and local radiations are very exceptional in the genus.

As part of an ongoing study on Vanilla diversity, the types and original materials of dozens taxa have been studied carefully. As a result, it has become apparent that several recently proposed species represent only range extensions of previously described entities. A total of 28 species names, six of them unpublished, and one generic name are placed under synonymy of previously described taxa. Consequently the number of accepted Vanilla species is reduced to 118 , a significant decrease of about $15 \%$; and the number of recognized Neotropical Vanilla species is shrunk by about a quarter, from 81 to 62 . Furthermore, we are certain that careful revision of additional taxa will result in more reductions in the future. Proposing multiple names for a species may appear like a harmless, merely taxonomic, affair, and reducing species is certainly not as popular and welcomed as describing new ones (Geiger 2020, Geiger et al. 2020). However, recognizing more species than there actually are found in nature may have unexpected consequences. Species are the fundamental units in macroecology, and tests of biogeographical patterns, such as ranges being larger at higher latitudes or the abundance being greater in the center rather than the edges of a range, may be significantly hampered by regional inflation (Isaac et al. 2004). Over-splitting of taxa may also have serious implications for conservation biology (Zachos et al. 2013, Garnett \& Christidis 2017). On the latter, Isaac et al. (2004) find that as species numbers increase, taxonomic inflation could potentially mask extinction rates and, at the same time, due to a reduction in the average geographical range and population size, will result in a higher proportion of threatened or extinct species. As a consequence, the assessments of species loss rates and of conservation priorities become unreliable.

Watteyn et al. (2020) offer an example of a nontaxonomical study on Vanilla where taxonomical inflation is highly detrimental. The authors use species distribution modeling to identify areas for conservation and sustainable cultivation of wild relatives of the vanilla crop. When using species distribution modeling, including the complete range is very important to assess the full environmental variation under which a species occurs. It is extremely important to have enough different data points to analyze, which is not possible when species have very narrow ranges and are known from a few specimens only. Studies on the natural dispersal of Vanilla seeds (Karremans et al. unpub.) may be seriously hindered by the large differences in recorded geographical ranges among Vanilla species. While the unusually broad distribution of members of the genus, as compared with other orchids, is masked by the restricted distributions reported in literature. Due to the narrow distribution, small populations and anthropological disturbance, conservation concerns for the recently described Vanilla denshikoira Flanagan \& Ospina-Calderón and $V$. karenchristianae Karremans \& P.Lehm. were raised by authors (Flanagan et al. 2018, Karremans \& Lehmann 2018). However, the taxonomical status of both of those species is discussed here and although their 
conservation status is not re-assessed, their ranges are significantly broadened, which could reduce the level of concern for their conservation initially indicated. Similarly, a population study of Vanilla bahiana Hoehne and $V$. pompona Schiede in Brazil finds that despite being widespread across their distribution the two species are mostly found in fragmented habitats and both are given a preliminary status of 'Endangered' (Ferreira et al. 2017). Nevertheless, the large number of specimens cited for both species, in addition to the their very broad distribution as shown here, certainly suggests that perhaps they are not of the highest concern for conservation among Vanilla species, let alone Orchidaceae.

Most novel plant species are discovered either by exploring remote areas or by carefully re-examining previously collected specimens. It is expected that a large part of those novelties belong to groups that are either of lesser interest, of complicated taxonomy, or are intrinsically highly diverse (Pupulin \& Karremans 2017). The odds of finding an undescribed species of Lepanthes (Pleurothallidinae) in an unexplored area is high (Pupulin \& Bogarín 2012), the odds of finding an undescribed species of Vanilla anywhere, on the other hand, are quite slim. This does not mean that all of them have been discovered and described. However, it is quite likely that there is already an available name among the many historically poorly understood taxa. Despite the availability of the seminal papers by Soto Arenas \& Cribb (2010) and Soto Arenas \& Dressler (2010), Vanilla is especially difficult taxonomically due to the obscurity of many names and the poor preservation of flowers. The broad distribution of Vanilla species also presents a challenge. When $V$. karen-christianae from Costa Rica was described, the types of Vanilla species from Mexico, Central America, Colombia and Ecuador were revised. Unfortunately, the name $V$. uncinata Huber ex Hoehne, based on a specimen from Brazil and placed in the synonymy of another species, was overlooked. The two are obviously conspecific which means that the species has a distribution range of at least $5000 \mathrm{~km}$. Such broad distributions are very uncommon in Orchidaceae in general, but relatively frequent in Vanilla. In fact, out of the 1281 orchid species reported from Mexico (data from AMO) and the 1600 species reported from Costa Rica (data from
JBL), some 30-35 species are shared with Brazil, or about $2.0-2.5 \%$. In contrast, more than half of the Vanilla species found in either country is also reported from Brazil.

By no means are we suggesting that there are no novelties to be discovered in Vanilla, there surely must still be a few. However, this number is probably limited given that the group is not particularly speciesrich, as compared to other orchids, and species are mostly lowland growers with a broad geographical distribution, reducing the opportunities for isolation. Contrary to what one may do when studying other orchids, in the case of Vanilla it is highly advisable to carefully review floras from distant regions as well as old names that apply to cryptic taxa, before proposing novelties. Having good records of the unusually broad distribution of Vanilla species may be even more valuable than describing poorly known and narrowly endemic new species.

Materials and methods. The original materials, including protologues, illustrations and specimens of dozens of Neotropical Vanilla species and their proposed synonyms were analyzed. Historical literature was accessed at the JBL library, online repositories (Biodiversity Heritage Library; Tropicos) or requested from private sources. Relevant specimens were photographed by us, accessed via the original depositories (GBIF-Global Biodiversity Information Facility; Harvard University Herbaria; INCTHerbário Virtual da Flora e dos Fungos; Muséum national d'histoire naturelle; Reflora-Herbário Virtual; The Herbarium Catalogue, Royal Botanic Gardens, Kew) or requested from the curators. We revised +650 specimens, either electronically or physically, from the following herbaria: ALCB, AMES, AMO, ASE, B, BM, BO, BRIT, CEN, CEPEC, CICY, COL, CR, CUZ, F, FLAS, G, GH, GOET, HAL, HB, HOXA, HUEFS, HUFU, HUPCH, HUT, IAN, JBL, K, L, LE, LL, MA, MBM, MG, MO, MOL, MW, NY, P, PR, PRC, RB, REU, SEL, SP, TEX, U, UB, UFRN, URP, US, USF, USJ, USM, VIES and W. The taxonomic status and nomenclature of these taxa is reevaluated to determine the adequate name usage through the application of the International Code of Nomenclature for algae, fungi, and plants (Turland $e t$ al. 2018). 
Vegetative and floral structures of living plants were photographed with a Nikon ${ }^{\circledR} 7100$ and Nikon ${ }^{\circledR}$ 810 camera using a AF-S VR Micro-NIKKOR 105 $\mathrm{mm} \mathrm{f} / 2.8 \mathrm{G}$ IF-ED lens. Those photographs were used to prepare Lankester Composite Dissection Plates (LCDP) using Adobe Photoshop ${ }^{\circledR}$. Plates include habit, flower, dissected perianth, column, anther cap and pollinarium, as well as other taxonomically informative characters depending on the taxa illustrated. LCDPs are prepared in such a way that

\section{TAXONOMIC TREATMENT}

Vanilla Plum. ex Mill., Gard. Dict. Abr. ed. 4: s.p. 1754. Lectotype:-Vanilla mexicana Mill., Gard. Dict. (ed. 8), no. 1. 1768. Replaced synonym: Epidendrum vanilla L., Sp. Pl. ed. 1, 2: 952. 1753.

Syn.: Vanillophorum Neck., Elem. Bot. 3: 134. 1790, nom. inval., opus utique oppr.

Syn.: Myrobroma Salisb., Parad. Lond. 2: t. 82. 1807.

Type:-Myrobroma fragrans Salisb., Parad. Lond.

2: t. 82. 1897, nom. illeg. E Epidendrum rubrum

Lam., Encycl. 1: 178. 1783 = Vanilla rubra (Lam.)

Urb., Repert. Spec. Nov. Regni Veg. Beih. 5: 157. 1920.

Syn.: Dictyophyllaria Garay, Bot. Mus. Leafl. 30:

231. 1986. Type:-Dictyophyllaria dietschiana (Edwall) Garay, Bot. Mus. Leafl. 30: 231. $1986=$ Vanilla dietschiana Edwall, Revista Centro Sci. Campinas 2: 192. 1903.

Syn.: Miguelia Aver., Turczaninowia 14(2): 45. 2011, syn. nov. Type:-Miguelia somae (Hayata) Aver., Turczaninowia 14(2): 49. 2011 = Vanilla somae Hayata, Icon. Pl. Formosan. 6: 88. 1916.

Averyanov \& Vuong (2015) segregated four species from southern and south-eastern China, Vietnam and Laos from Vanilla into the newly proposed Miguelia (Averyanov 2011). The species belonging to the proposed genus differ from Vanilla in the "sympodial, branched, cymose inflorescence". However rare, branching inflorescences can be occasionally found in many Vanilla species including V. palmarum (Salzm. ex Lindl.) Lindl. and V. planifolia Andrews, and seems to be the predominant condition of the inflorescences of, for example, $V$. costaricensis Soto Arenas and $V$. armoriquensis Damian \& Mitidieri (Fig. 1), both of which belong to Vanilla subgen. Vanilla. What has been defined by the authors as a cymose inflorescence they are easily comparable among the diverse taxa. All photographs are by the authors except when indicated otherwise. Distribution maps based on a world Imagery updated to July 1, 2020 from Esri, Maxar, Earthstar Geographics, CNES/Airbus DS, USDA FSA, USGS, Aerogrid, IGN, IGP, and the GIS User Community. The Extent of Occurrence (EOO) was assessed using the studied specimens with the Geospatial Conservation Assessment Tool (GeoCAT; Royal Botanic Gardens, Kew: http://geocat.kew.org).

with two terminal flowers in Miguelia, is in fact a strongly compacted racemose inflorescence, with distichous flowers, placed almost, not exactly, at the same height, terminating in a distichous vestige (see Fig. 1 in Averyanov \& Vuong 2015). DNA data is not yet available for the species included in Miguelia, but there is no doubt they belong within Vanilla.

Vanilla cruenta (Aver. \& Vuong) Karremans, Damian \& Léotard, comb. nov.

Bas.: Miguelia cruenta Aver. \& Vuong, Taiwania 60: 36. 2015.

Selected Neotropical Taxa

1. Vanilla columbiana Rolfe, J. Linn. Soc., Bot. 32: 468. 1896. Fis. 2-5, 6 a.

TYPE: [COLOMBIA]. New Granada: Valley of the Magdalena, Goudot s.n. (holotype, K!; isotype, P!, Fig. 2)

Syn.: Vanilla calyculata Schltr., Repert. Spec. Nov. Regni Veg. Beih. 7: 42. 1920, syn. nov.

TYPE: COLOMBIA. Cauca: 1000 m, M. Madero s.n. (holotype, B, destroyed). Neotype (designated by Soto Arenas \& Dressler 2010): Colombia. Valle: Municipio de Tulúa, Corregimiento Mateguadua, Jardín Botánico, laderas en vía de repoblación natural, altura 1100 m, 29 Sept. 1984, W. Devia 815 (MO-3245054, not located; illustration in Soto Arenas \& Dressler, Fig. 3).

Syn.: Vanilla hameri Soto Arenas, nom. nud. in sched., syn. nov.

Syn.: Vanilla esquipulensis Archila \& Chiron, Richardiana 13: 6. 2012, syn. nov.

TYPE: GUATEMALA. Collecté par Fredy Archila, avril 2012, La aldea el barrial, poussant sur une plante d'anone, Esquipulas, Chiquimula, $900 \mathrm{~m}$ 


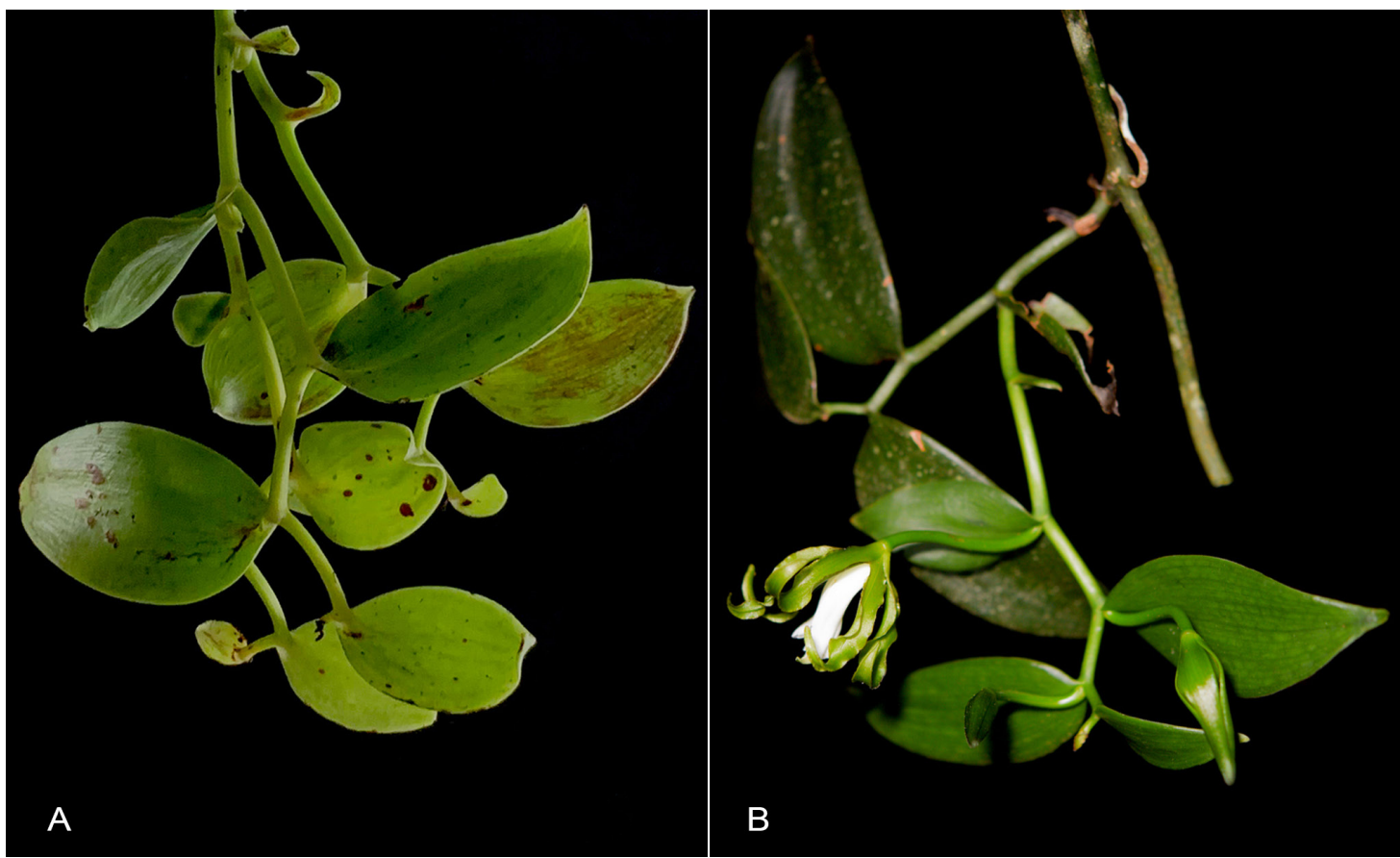

FIGURE 1. The racemose inflorescences of certain Vanilla species become branched over time. A. Vanilla costaricensis Soto Arenas. B. Vanilla armoriquensis Damian \& Mitidieri. Photos by APK based on Karremans 7308 (A) and AD based on Damían et al. 904 (B).

d'altitude, FA-1300 (holotype: BIGU, USAC; isotype: BIGU, USAC; illustration!).

Hemiepiphytic vine, branching, leafy vine, up to 4 $\mathrm{m}$ high. Stems flexuose, terete, furrowed and lustrous, green, 6-12 $\mathrm{mm}$ in diameter; internodes $7.0-15.5 \mathrm{~cm}$ long. Aerial roots terete, one per internode emerging laterally to the leaf, up to $8.2 \mathrm{~cm}$ long, $2-3 \mathrm{~mm}$ in diameter. Leaves sessile to subpetiolate, the petiole up to $7-10 \mathrm{~mm}$ long; the blade oblong to ligulate, the base rounded, the apex obtuse, shortly apiculate, coriaceous fleshy, apparently stiff and xerophytic, the margins slightly revolute, $7.5-21 \times 1.7-4.0 \mathrm{~cm}$. Inflorescence a 12-14 successive flower raceme, 2-4-opened simultaneously, 4.2-6.0 cm long; peduncle fleshy, subterete, ca. $1 \mathrm{~cm}$ long; rachis terete, green, ca. 4-6 cm long. Floral bracts widely ovate, obtuse, green, concave, progressively smaller, up to $10 \times$ $6 \mathrm{~mm}$. Flowers pendant, very showy, sepals and petals whitish green to yellowish green, in the apex more dark green, lip white with deep yellow in the center and green in the apex, ca. $9 \mathrm{~cm}$ long; strongly fragrant. Ovary terete, smooth, sulcate, ca. 4.0-4.5 $\times 4 \mathrm{~mm}$. Dorsal sepal oblanceolate to narrowly elliptic, recurved above the middle, apex subacute to obtuse, somewhat thickened, subcalyptrate, basally canaliculate, smooth, base attenuate sub-unguiculate, ca. $12-13$ veined, $66-80 \times 8.0-17 \mathrm{~mm}$. Lateral sepals oblong to narrowly elliptic, oblique, recurved above the middle, the lower margin more incurved, apex subacute to obtuse, somewhat thickened, subcalyptrate, basally attenuate sub-unguiculate, smooth, ca. 12-13 veined, $67-80 \times 12-17 \mathrm{~mm}$. Petals obliquely oblanceolate, deeply recurved above the middle, lower margin more incurved, apex attenuate, rounded, very attenuate at base, acute, with a flat keel on the abaxial surface, 1 $\mathrm{mm}$ wide, ending in a free, conic, blunt, short, $1 \mathrm{~mm}$ long apicule; ca. 11-12 veined, 65-80 × 9-16 mm. Lip attached to the column along the margins of the basal half ca. 41-46 mm, tubular, bell-shaped, trilobed; abaxially deeply grooved along on the midvein; when spread out 78-90 × 36-45 mm; long unguiculate, the claw apically rugose, papillose on the inner surface, 26 $\times 3.0-3.8 \mathrm{~mm}$; the blade cymbiform, when spread out approximately obovate in outline, ca. 36 veined, veins branched; the lateral lobes rounded, incurved forming 


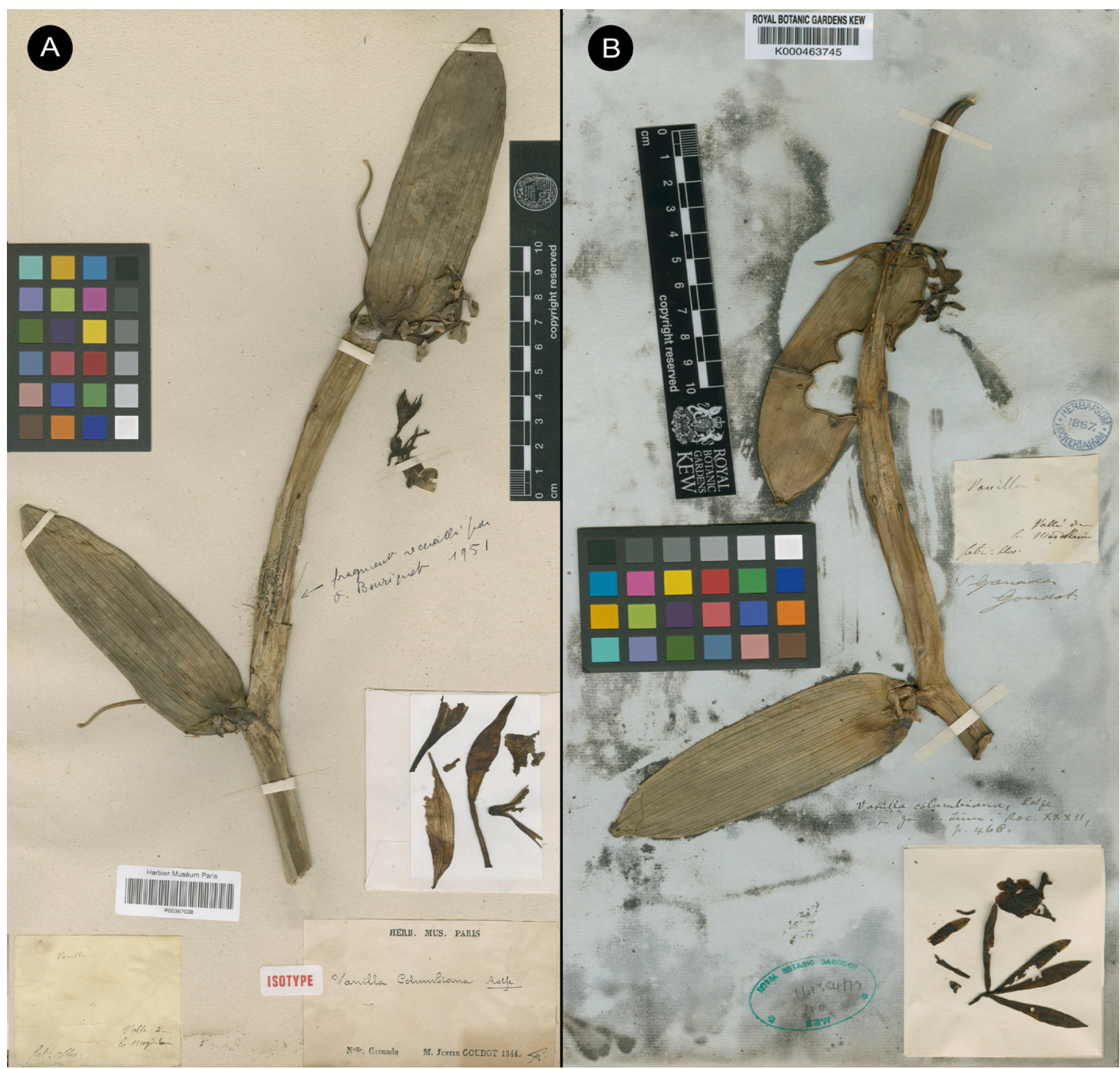

Figure 2. Type material of Vanilla columbiana Rolfe. A. Holotype K-000463745 (c) copyright of the Board of Trustees of the

Royal Botanic Gardens, Kew. B. Isotype P-00367038 @ copyright of the Muséum national d'histoire naturelle, Paris.

a gullet around the column, margins entire to crenulate, apically overlapping, constricted near the midlobe base, 37-39 $\times 14 \mathrm{~mm}$; the midlobe spreading, subquadrate, deeply emarginate to bilobed, recurved, margins dentate, undulate, veins conspicuously thickened, 14$16 \times 21-26 \mathrm{~mm}$; penicillate callus at ca. $41 \mathrm{~mm}$ from the base, $4.5 \times 3.8 \mathrm{~mm}$, made up by $8-10$ flabellate, shortly lacerate, retrorse, scales, some of them united to each other along the lateral margins; extending for about $25-27 \mathrm{~mm}$ to the apex, ca. $6 \mathrm{~mm}$ wide, $2-3 \mathrm{~mm}$ high, progressively more thickened towards the apex of the lip, forming an apical, swollen, low cushion, convex, rugose, papillose, with yellowish-orange hairs in the basal part. Column subterete, subclavate, slender, slightly sigmoid, $51-55 \times 4 \mathrm{~mm}$; ventrally flattened and lanuginose at the distal half; apex with two vertical wings, narrow, triangular, flabellate, undulate, ca. $4 \times$ $1 \mathrm{~mm}$. Stigma trilobed, the lobes emergent; rostellum trapezoid, flabellate, $2.0 \times 4.5 \mathrm{~mm}$; lateral lobes transversely oblong, flabellate, $1.2 \times 1.8 \mathrm{~mm}$. Anther versatile, attached to the wide clinandrium margin by a broad filament, triangular to ovate, truncate emarginate, $5 \times 5 \mathrm{~mm}$. Fruit bright brown when mature, fragrant, trigonous, $8-15 \mathrm{~cm}$ long. 


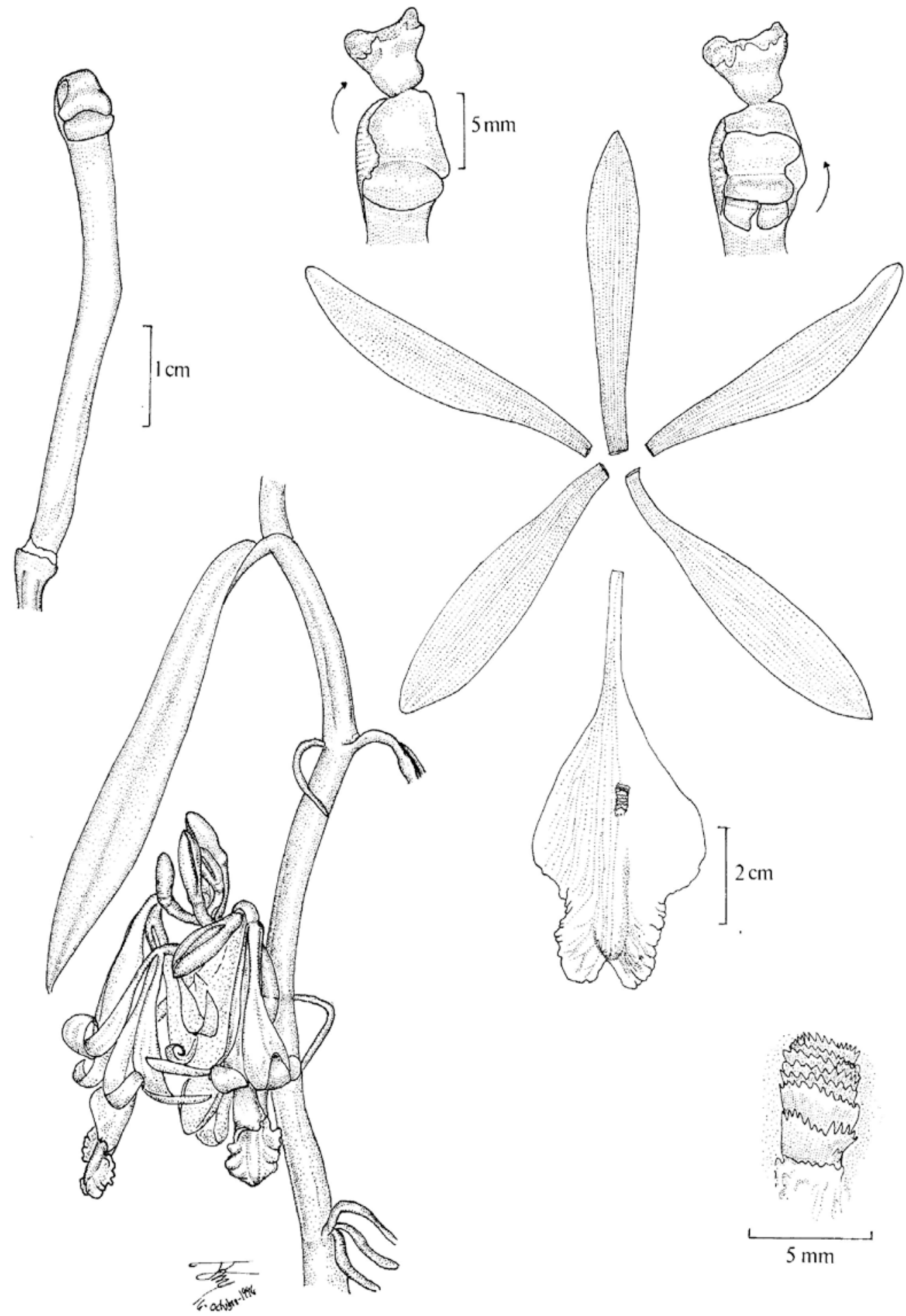

FIgURE 3. Vanilla columbiana. Illustration of Devia 815, the neotype of V. calyculata Schltr. selected by Soto Arenas \& Dressler (2010) and published therein. 


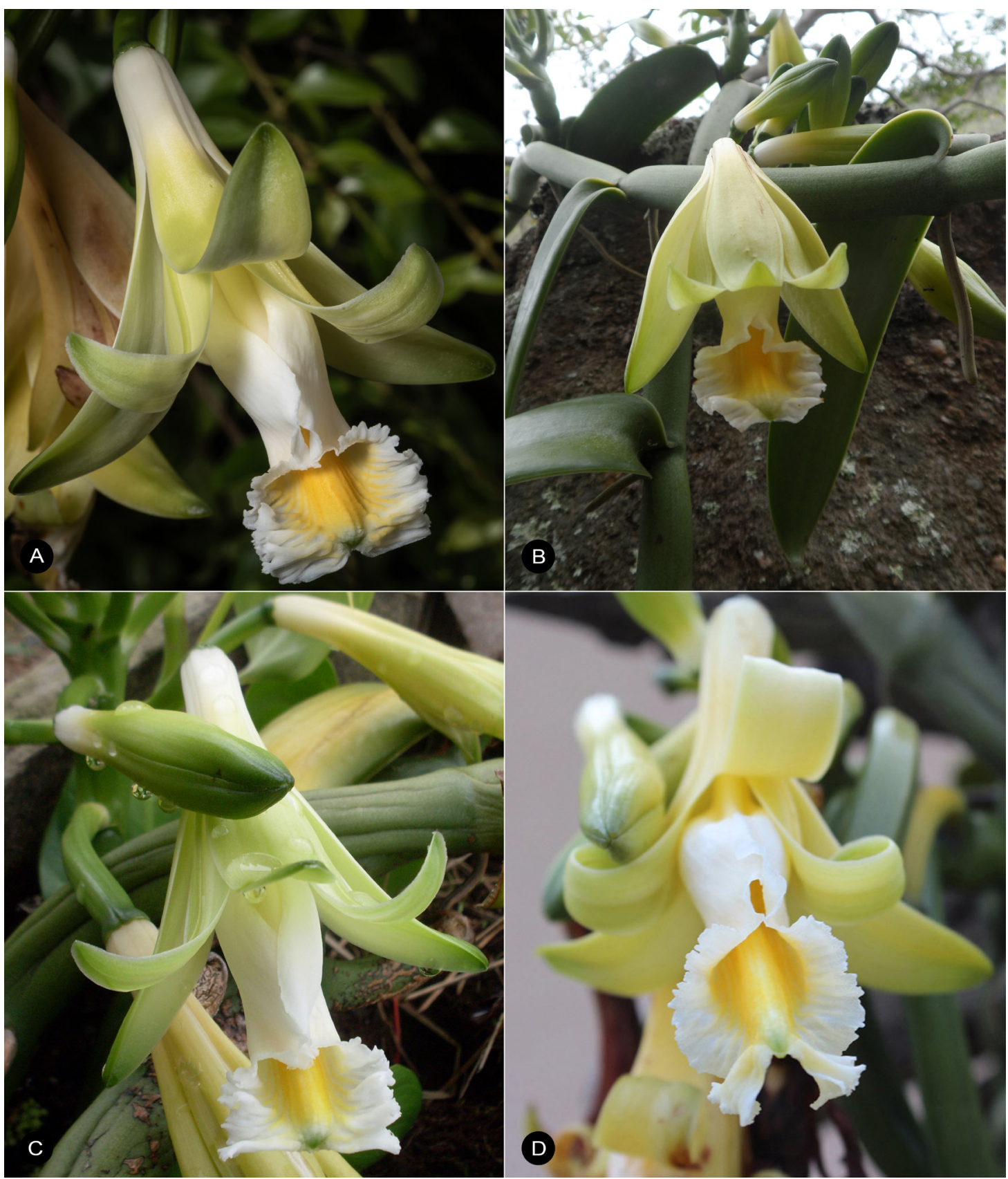

Figure 4. Vanilla columbiana flowering specimens from different localities across its distribution. A. Colombia, Moreno s.n.

B. Colombia, Díaz 1369. C. Colombia, González s.n. D. Honduras, Vega s.n. Photographs by the collectors kept at JBL.

SPECIMENS STUDIED: HONDURAS: Comayagua: Thicket along river, plain near Sihuatepeque. $1050 \mathrm{~m}$ altitude. 23 Jul. 1936, T.G. Yuncker, R.F. Dawson \& H.R. Youse 6045 (AMES-46667!; G; K!; MO-1115382; NY!). Unknown locality, H. Vega s.n. (JBL-photograph!; Fig. 4D). EL SALVADOR: La Palma-Finca El Refugio, Río Nanuapa,
1000 m, 4 Mar. 1969. 11 Apr. 1969, O. Pank \& F. Hamer 203 (AMES-112862!; AMES-113837!). COLOMBIA: Cundinamarca, Fusagasuga, vereda "Chinauta", finca "El descanso", 1200 m, 3 Abr. 1988, F. Sarmiento 2140 (COL!). Cauca: Dagua, 960 m, S. Moreno s.n. (JBL-photograph!; Fig. 4A, 5B). Santander: Zapatoca, D. Díaz 1369 (JBL- 

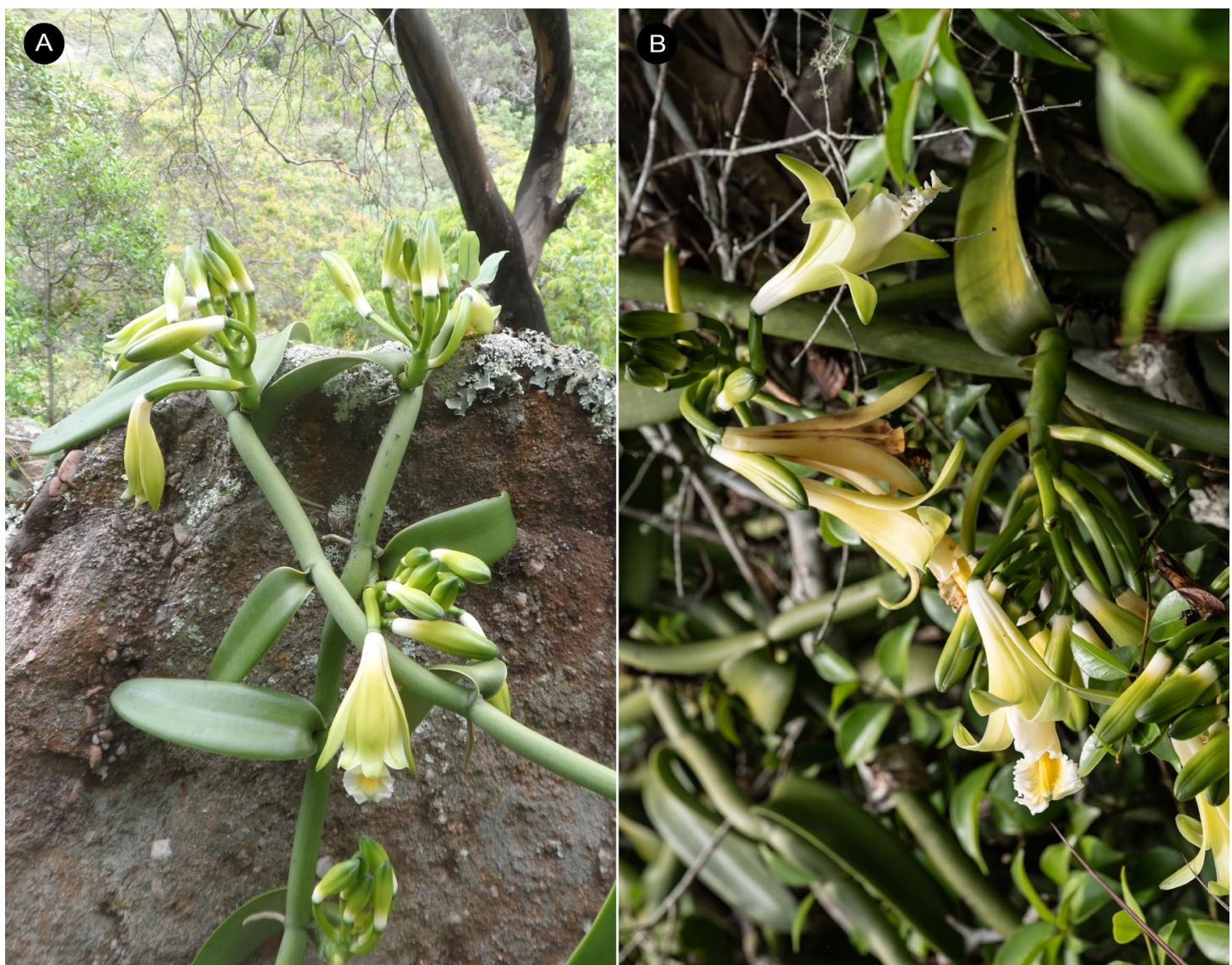

Figure 5. Vanilla columbiana growing in situ in Colombia. A. Cauca: Dagua, Moreno s.n. B. Santander: Zapatoca, Díaz 1369. Photographs by the collectors kept at JBL.

photograph!; Fig. 4B, 5A). Without collecting data, R.T. González s.n. (JBL-photograph!; Fig. 4C).

OTHER SPECIMENS: MEXICO: Michoacan: Hacienda de Coahuayula, Feb. 1901, G.M. Emrick 16 (F-95476). GUATEMALA: Esquipulas, Chiquimula, dans des zones proches du mirador de Esquipulas, 600 m, Fredy Archila, Mar. 1999, FA s.n. (BIGU); Affluent du Río Jocotan Chiquimula, dans un ruisseau proche, $500 \mathrm{~m}$, Fredy Archila, Apr. 2000, FA s.n. (BIGU). HONDURAS: Morazan: Aguas abajo de la Quebrada de Sta. Clara, 850 m, 28 Apr. 1948, A. Molina 808 (F-1676153); Quebrada Santa Clara, ca. 2 $\mathrm{km}$ al norte del Zamorano, $800 \mathrm{~m}$. Mpio de San Antonio de Oriente. 19 Jun. 1996. J.L. Linares 3386 (MEXU). El Paraíso: Mpio. Morocelí, Quebrada El Cajocote conocida también como El Terrero, $8.7 \mathrm{~km}$ al $\mathrm{N}$ de Morocelí, por el camino a Mata de Plátano, 14 $10^{\prime} 10^{\prime \prime} \mathrm{N}, 86^{\circ} 51^{\prime} 06^{\prime \prime} \mathrm{W}, 680$ m, 29 Apr. 2004, J.L. Linares 7313 ( MEXU). Barranco de las Mesas, 900 m, 1 Ago. 1957, L.O. Williams \& A. Molina 8575 (F-1590341), Open savannah, Las Mesas region near
Yuscarán, Aug. 1960, H.W. Pfeifer 1454 (US-2563382). COLOMBIA: Tolima: Auf äumen in Zavannen-Wäldern bei La Plata, 800-1500 m. 3 Dec.1882. F.C. Lehmann 2263 (BM; G). [Unknown locality] Cultivated, E. Dryander 2379 (BM). "Columbien” Lehmann s.n. (W-59043).

Distribution: Mexico, Guatemala, El Salvador, Honduras and Colombia (Fig. 6A).

EXTENT OF OCCURRENCE:-288,210.392 km².

Vanilla columbiana can be especially recognized by the thick, fleshy stems, that can be up to half the width of coriaceous leaves. It is well adapted to drought, with the fleshy stems and leaves becoming sulcate or corrugated under extreme conditions. The leaves are oblong to ligulate, the inflorescence is also typically thick, short in relation to the leaf and notoriously multi-flowered with one to a few flowers open at once. The flowers have non-spreading, slightly recurved 
segments, the sepals and petals are yellowish green, the lip is white with a deep yellow middle and green ape. The ovary has an apical thickening (calyculate), which is more evident in dried material. The lip is bell-shaped, trilobed, the midlobe is subquadrate, with the apex emarginate and the margins undulate, and the central veins conspicuously thickened forming a longitudinal 'cushion' from the penicillate callus to the apex.

Rolfe described Vanilla columbiana on the basis of material collected by Goudot in the Valley of the Magdalena, Colombia. The identity of this species has remained cryptic, and the name virtually unused. The thick stem, coriaceous leaves that are shorter than the internodes, and undulate, trilobate lip with a quadrate apex and thickened central veins characterize the species. Soto Arenas \& Cribb (2010) suspected an affinity with $V$. calyculata, which was also described on the basis of Colombian material, but the poor state of the type material prevented a definitive decision. We find that the vegetative features observed in the holotype and isotype specimens, as well as the floral features described in the protologue, are congruent with our current concept of $V$. calyculata. As such Vanilla columbiana, which has priority, replaces the concept of $V$. calyculata as circumscribed by Soto Arenas \& Dressler (2010).

Vanilla columbiana has not been reported in countries south of Colombia. However, some of the Brazilian materials determined as Vanilla chamissonis Klotzsch and $V$. vellozii Rolfe are extremely similar to $V$. columbiana. The species currently treated as $V$. chamissonis in Brazil, as illustrated for example by Hoehne in Flora Brasilica (Hoehne 1945), is similar but different from our concept $V$. columbiana. However, the illustration of $V$. chamissonis published by Cogniaux in Flora Brasilensis is virtually indistinguishable from $V$. columbiana. In Brazil, two forms of $V$. chamissonis have been recognized by several authors, perhaps one of is conspecific with $V$. columbiana. Careful study of living material and the type specimens of $V$. chamissonis and $V$. vellozii, as well as the closely related Vanilla argentina Hicken and V. carinata Rolfe, is necessary to definitively resolve their identity and the relationships among these taxa.

When proposing V. esquipulensis, Archila Morales \& Chiron (2012) cited a few superficial differences from Vanilla calyculata $(=$ V. columbiana), essentially a thicker stem, a wider, petiolate leaf, and the noncalyculate ovary. Nevertheless, specimens of $V$. columbiana from Colombia (Figs. 4A-C, 5) show a thick stem and broad leaves, and flowers that are indistinguishable in every aspect from the northern Central American material described as V. esquipulensis (Fig. 4D), including the calyculate ovary, a feature that is variable and depends on the hydration of the material (inconspicuous in living plants and becoming more evident as the specimen becomes dehydrated).

Soto Arenas used the name "Vanilla hameri Soto Arenas" on herbarium specimens from El Salvador and Honduras that he later identified as $V$. columbiana. A few authors have cited this name as an accepted species of Vanilla, but it was never formally published and its use should be avoided.

2. Vanilla hartii Rolfe, Bull. Misc. Inform. Kew 1899(151-152): 133. 1901. Fig. 6B, 7-9.

TYPE: TRINIDAD [TRINIDAD \& TOBAGO]. Cabasterre Arima, Apr. 1898, J.H. Hart 6355 (holotype: K-000463205!, Fig. 7; isotype: AMES-67784!).

Syn.: Vanilla leprieurii Portères, Bull. Soc. Bot. France 98: 94. 1951, syn. nov.

TYPE: FRENCH GUIANA. Cayenne: dans les forêst humides, en 1846, Leprieur s.n. (holotype: P-04026348!, Fig. 8).

Syn.: Vanilla perplexa Soto Arenas, nom. nud. in sched., syn. nov.

Hemiepiphytic, branching, leafy vine, up to several meters high. Stems dark green, subterete, smooth, up to $6 \mathrm{~mm}$ in diameter; internodes straight to arched, $3.9-12.5 \mathrm{~cm}$ long. Aerial roots subterete, $1.0-3.5 \mathrm{~mm}$ in diameter, flexuous, one per internode emerging laterally to the leaf. Leaves usually shorter than the internodes; the petiole 4-11 mm long; blade elliptic, acuminate, lightly recurved to the apex, 5.0-15.0 $\times$ 1.1-4.4 cm, 9-17-veined. Inflorescence a raceme, lateral, simple, producing up to 8 successive flowers per raceme, 1-2- opened simultaneously; peduncle short, subterete, up to $0.7 \mathrm{~cm}$ long; rachis up to $1.5 \mathrm{~cm}$ long. Floral bracts dark green, sessile, ovate, acute, concave, $3.5-9 \times 2.5-8 \mathrm{~mm}$. Flowers ephemeral, segments spreading, the ovary whitish, apically greenish, sepals 


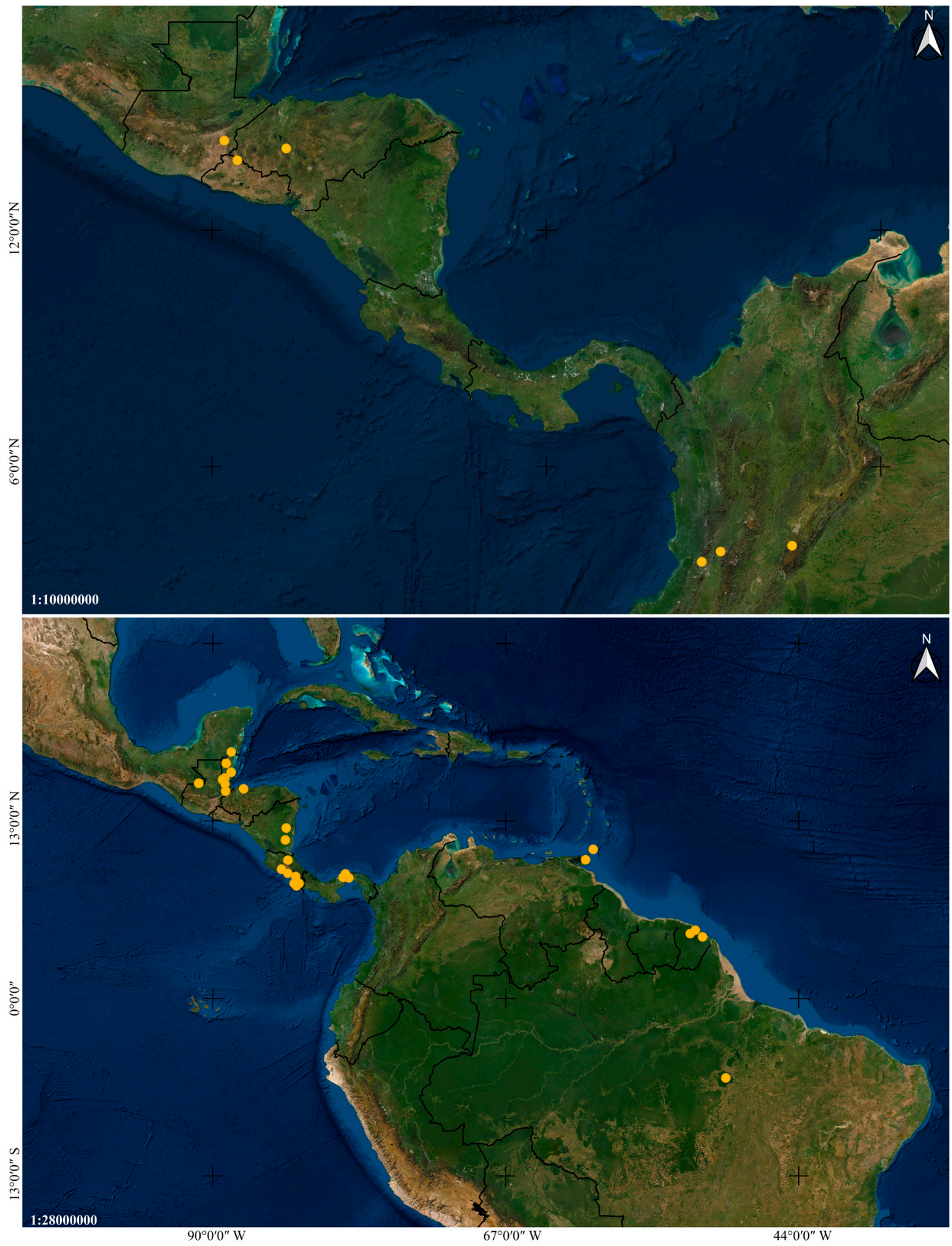

FIgURE 6. Distribution maps of Vanilla species based on studied specimens. A. Vanilla columbiana Rolfe. B. Vanilla hartii Rolfe. Images by IC. 


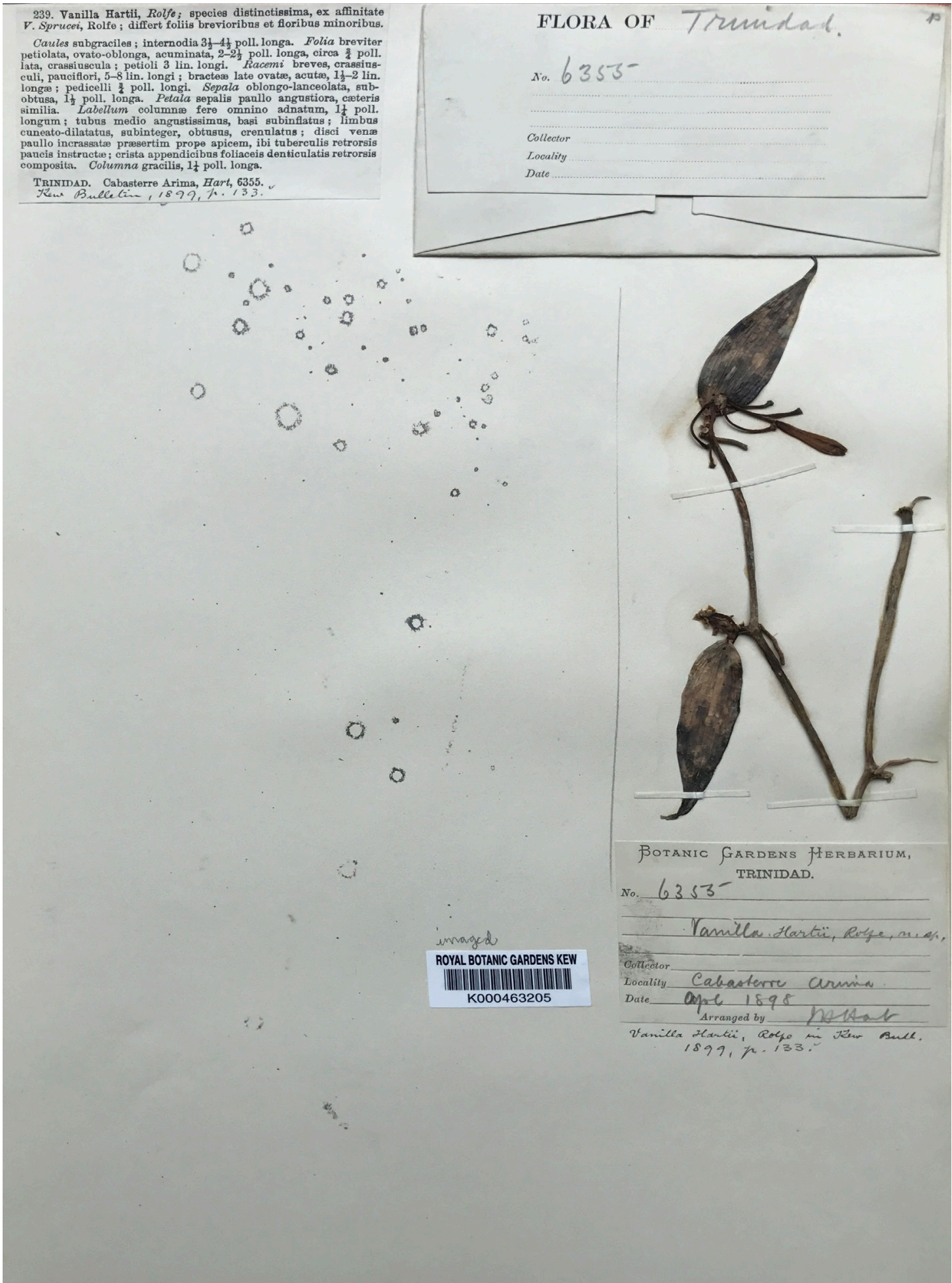

FIGURE 7. Holotype of Vanilla hartii Rolfe, J.H. Hart 6355 (K-000463205). Photograph by APK. 


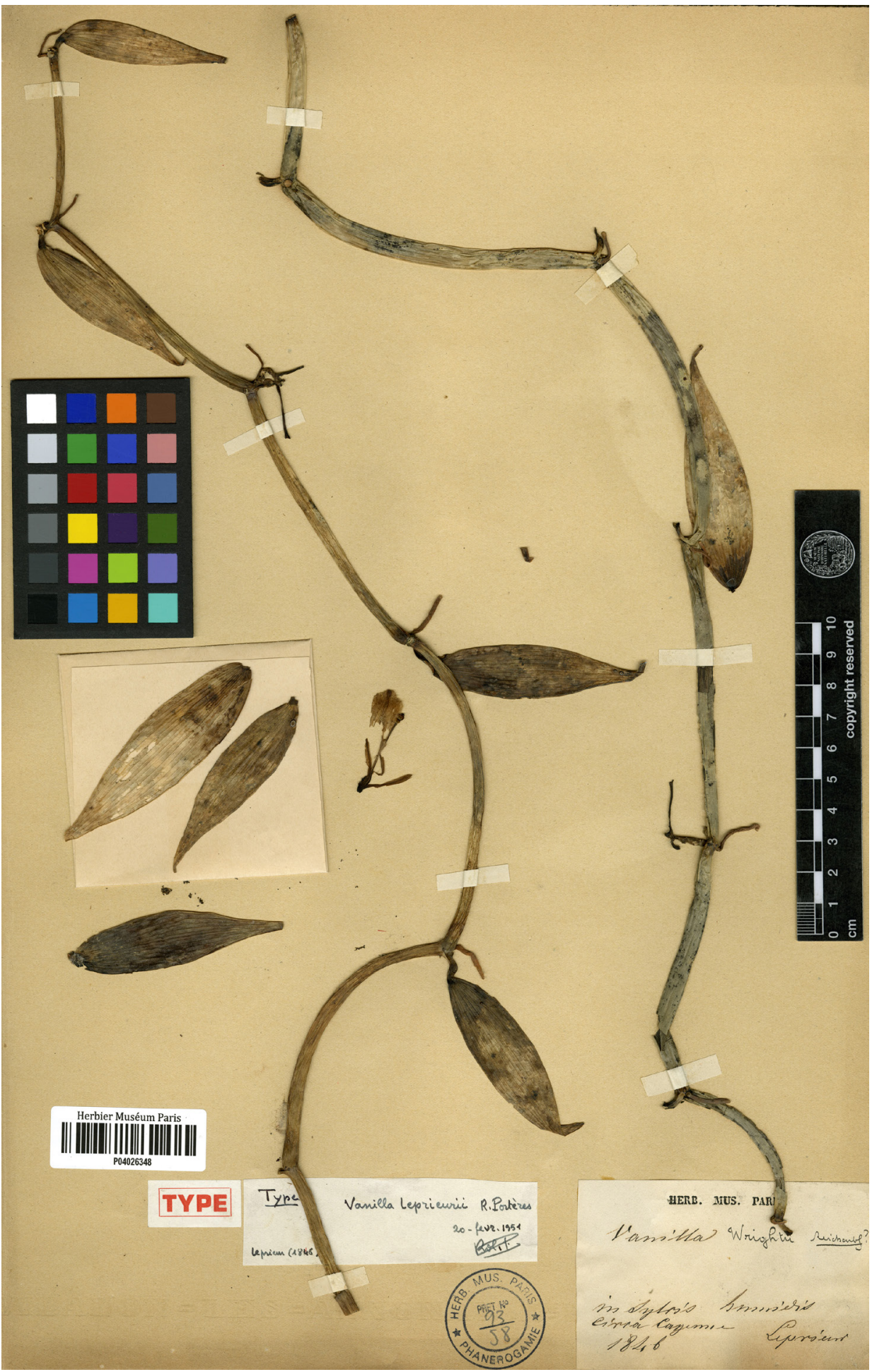

Figure 8. Vanilla hartii, holotype of Vanilla leprieurii Portères, Leprieur s.n. (P-04026348) C) copyright of the Muséum national d'histoire naturelle, Paris. 
white, abaxially greenish, petals white, abaxially greenish on the midvein, lip white, lightly greenish at the penicellate callus apex, and column white, with the rostellum yellowish, anther cap greenish to yellowish; fragrance imperceptible. Ovary subterete, smooth, lightly arcuate, $14.0-31.0 \times 2.5-3.3 \mathrm{~mm}$, green, basally whitish. Dorsal sepal oblanceolate, obcuneate, acute, somewhat concave, arcuate, almost porrect, fleshy, 11-13-veined, $30-50 \times 7-10 \mathrm{~mm}$. Lateral sepals oblanceolate, obcuneate, acute, somewhat arcuate, divergent, recurved, fleshy, 11-13-veined, 36-49 × 5-12 mm. Petals oblanceolate, attenuate, obtuse, almost porrect; abaxially with a longitudinal prominent keel, 9-11-veined, 34-48 $\times 4-10 \mathrm{~mm}$. Lip fused to the column base along the margins for $18-26 \mathrm{~mm}$; tubular, trumpet-shaped, basally gibbous, trilobed; when spread out $37-43 \times 14-25 \mathrm{~mm}$; narrowly unguiculate, the claw slightly sigmoid, minutely papillose, 15.0-16.0 $\times 2.5-3.0 \mathrm{~mm}$; the blade cymbiform, when spread out obovate in outline, 21-29-veined, the veins progressively thickened towards the apex forming grooves, minutely papillose; the lateral lobes rounded, margins dentate to denticulate, undulate, with teeth up to $3.5 \mathrm{~mm}$ long; the midlobe emarginate, recurved, margins denticulate to crenate, undulate; penicillate callus $26-30 \mathrm{~mm}$ from the base, $4-5 \times 3 \mathrm{~mm}$, made up by $5-7$ imbricate, flabellate, retrorse, laciniate scales; extending for about $15-17 \mathrm{~mm}$ to the apex, 3.0-3.5 $\mathrm{mm}$ wide, progressively thickened towards the apex, oblanceolate, obtuse, fleshy, inconspicuously papillose. Column subterete, lightly arcuate, $3.0-3.8 \times 0.3 \mathrm{~cm}$, from similar width along, ventrally flattened, slightly pubescent below the stigma, apex with 2 obliquely obtuse, retrorse wings, 2.5-3.0 × 1.5-2.0 mm. Stigma trilobed, the lobes conspicuous. Rostellum subquadrate, convex blade. Anther basally hinged to the column, movable, obovate, 2.7-2.9 × 1.6-1.8 mm. Pollen a sticky, granular mass. Fruit green, terete, dehiscent, fragrant, $5.3-15.9 \times 0.4-1.5 \mathrm{~cm}$.

SPecimens STUdied: GUATEMALA. Izabal: Quebradas, 19-22 May 1919, H. Pittier 8589A (NY!, US-1013493, AMO-photo!). Swamps of Salomón Creek, 1/2-1 mi. south of Bananera, 50 m. 6 Apr. 1940. J.A. Steyermark 38944 (F1043051, AMO-photo!). BELIZE: Toledo District. Southern Maya Mountains, Bladen Nature Reserve, mountains 1.7 airline north of the Ek Xux archeological site, $16^{\circ} 31^{\prime} 05^{\prime \prime}$ N, 88 54'11" W, 500-600 m, 24 May 1996, G. Davidse 36251 (BM!, MO!, SEL!). Camp 3, 6-8 km southeast of Union Camp. Trail from camp 3 toward Cabro on the Jimmy cut trail, $16^{\circ} 23^{\prime} 14^{\prime \prime} \mathrm{N}, 89^{\circ} 04^{\prime} 37^{\prime \prime} \mathrm{W}, 665-700 \mathrm{~m}, 17$ Feb. 1997, T. Hawkins 1462 (SEL!). Cayo. Pine Ridge, Bull Run Overseas estate, near one of the small creeks, outlet of the lake, 17.6033, -88.90583, $530 \mathrm{~m}, 29$ Apr. 2014, B. Holst, E. Baron, L. Birch, D. Troxell 9896 (SEL-photo!). Toledo. Pine Hill Property across Rio Grande River from Belcampo Estate, $5 \mathrm{~km}$ by air $\left(20^{\circ}\right.$ true north bearing) NNE of Forest Home, Punta Gorda, 16.1866, -88.8213, 25 m, 29 May 2014, E. Baron et al. 38 (SEL-photo!). Stann Creek, Outlier, along trail on slopes to summit, 16.81233, -88.50135305, 370 m, 11 Apr. 2018, B.K. Holst et al. 11306 (SEL-photo!). HONDURAS: Atlántida: Lancetilla valley, near Tela; 20 to $600 \mathrm{~m}, 6$ Dec. 1927-20 Mar. 1928, P.C. Standley 52824 (AMES!, F!, US!). NICARAGUA: Río Kukarawara, Región Autónoma Atlántica Sur. Approx. $1 \mathrm{~km}$ up river from Tortuguero, $2-3 \mathrm{~km}$ into forest on right-hand side of river, $12^{\circ} 50^{\prime} \mathrm{N}, 84^{\circ} 12^{\prime} \mathrm{W}$ [24 m], 4 Jul. 1991, L.H. Pendleton 8 (MO!). Zelaya: Caño Zamora on Río Rama; ca. $11^{\circ} 57^{\prime} \mathrm{N}, 84^{\circ} 16^{\prime} \mathrm{W}, 10 \mathrm{~m}, 16$ May 1978 , W.D. Stevens 8835 \& B.A. Krukoff (SEL!). COSTA RICA: Heredia: Sarapiquí, Chilamate. Finca El Bejuco, $\mathrm{S}$ end of Cerros Sardinal (N of Río Sarapiquí), $10^{\circ} 27^{\prime} \mathrm{N}, 84^{\circ} 04^{\prime} \mathrm{W}$, 60 m, 24 Jan.1987. M.H Grayum 7998 \& T. Ray (MO!). Puntarenas: Buenos Aires, Volcán, Cacao, orillas del Río Cacao en bosque secundario bajo el puente de la Carretera Interamericana, $9^{\circ} 13^{\prime} 10.441^{\prime \prime} \mathrm{N}, 83^{\circ} 28^{\prime} 19.002^{\prime \prime} \mathrm{W}, 449 \mathrm{~m}$, 20 Mar. 2013, flowered in cultivation at Jardín Botánico Lankester 7 Dec. 2014, A. Karremans 5828, D. Bogarín, J. Cambronero \& F. Pupulin (JBL-spirit; Fig. 9). Garavito. P. N. Carara. Cuenca del Tárcoles. Saddle between Cerros Quebrada Bonita and Montañas Jamaica, headwaters of Quebrada Bonita, and ridge to N, $9^{\circ} 46^{\prime} 00.0000^{\prime \prime} \mathrm{N}$, $84^{\circ} 34^{\prime} 00.0002^{\prime \prime} \mathrm{W}, 420$ to $585 \mathrm{~m}, 27$ Jul. 1995, M.H. Grayum 1752 (MO!). Golfito. Refugio Nacional de Vida Silvestre Golfito. Cerro Nicuesa. Común en la parte alta de la ladera oeste del Refugio, $8^{\circ} 41^{\prime} 30^{\prime \prime} \mathrm{N}, 83^{\circ} 12^{\prime} 50^{\prime \prime} \mathrm{W}$, 345 m, 7 Abr. 1994, G. Rivera 2281 \& G. Herrera (CR!). Cantón de Osa, Aguabuena. Cuenca superior de Quebrada Aguabuena, 18 Jan. 1991, G. Herrera 4846 (CR!, MO!). Eastern Osa peninsula. Understory vegetation on the ridge of forest bordering cattle pasture, within $1 \mathrm{~km}$ of $8.70686 \mathrm{~N}$, $-83.59142 \mathrm{~W}$ [8 $\left.8^{\circ} 42^{\prime} 24.696^{\prime \prime} \mathrm{N}, 83^{\circ} 35^{\prime} 29.111^{\prime \prime} \mathrm{W}, 379 \mathrm{~m}\right]$, M.M. Mayfield 81-03-81-3117 (MO-6133305!). Eastern Osa peninsula. More than $500 \mathrm{~m}$ from edge of primary moist tropical forest, $8.51677 \mathrm{~N},-83.40693 \mathrm{~W}$ [8 $8^{\circ} 31^{\prime} 0.372^{\prime \prime}$ N, 324'24.948" W, 246 m], M.M. Mayfield 1480-14801603 (MO-6133300!). Hilly slopes west of Villa Nueva, just northwest of Londres and the Río Naranjo, ca. $9^{\circ} 28^{\prime}$ N, $84^{\circ} 5^{\prime}$ W, 200 m, 10 Feb. 1988, W.C. Burger 12251 \& J. Gómez-Laurito (USJ!, F-2009056!, AMO-photo!). San José: Pérez Zeledón. Rolectada por Gabriel Barboza. $A$. Karremans 7262 (JBL!). PANAMA: Barro Colorado Island. 


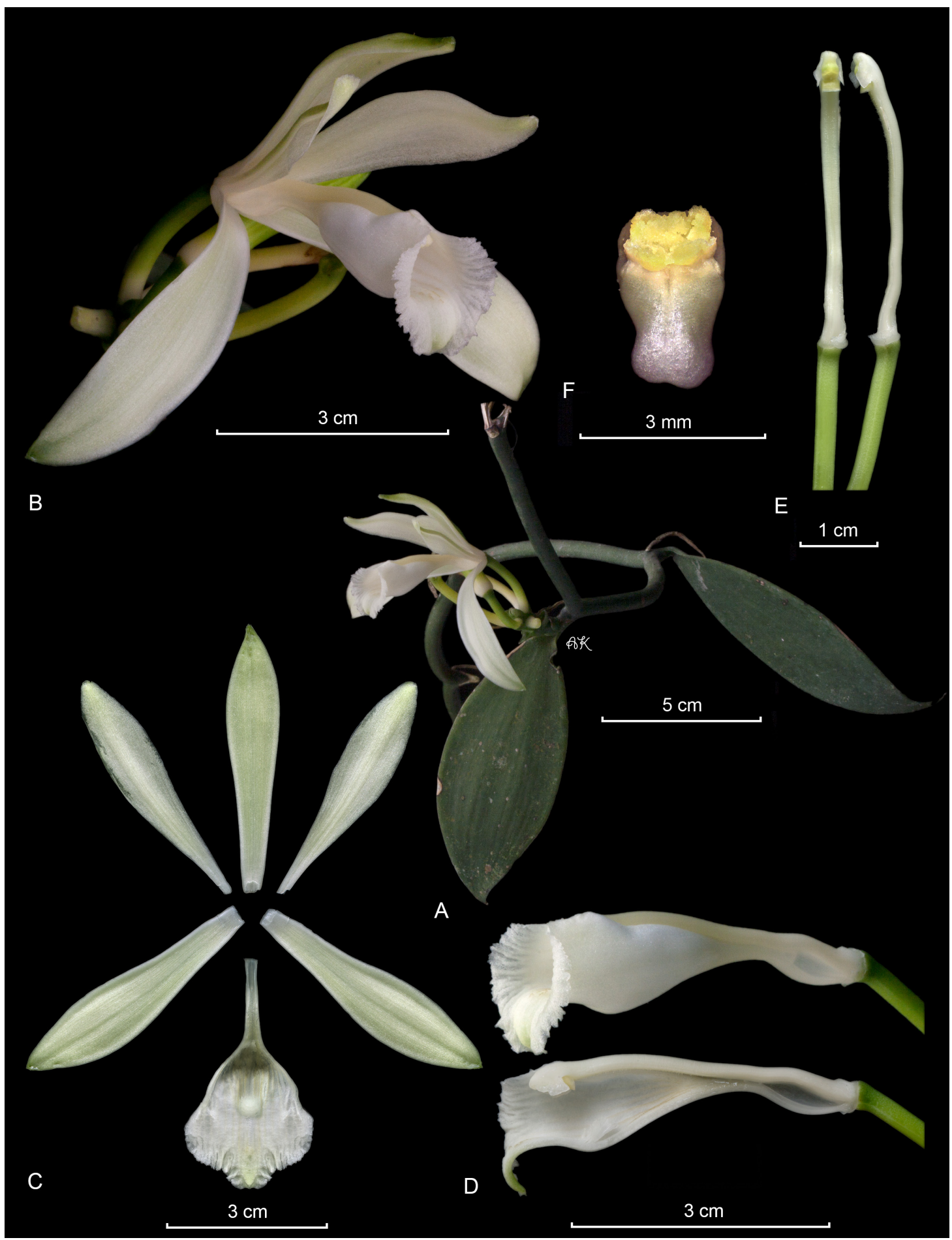

Figure 9. Lankester Composite Dissection Plate (LCDP) of Vanilla hartii. A. Habit. B. Flower. C. Dissected perianth. D. Lip and column lateral view. E. Column, ventral and lateral view. F. Anther cap and pollinia. By APK based on Karremans 5828 (JBL-spirit). 
Cana zone, 10 Jan. 1940, F.W. Hunnewell 16433 (AMES!, AMO-photo!). Colón: Santa Rita ridge road; ca. $22 \mathrm{~km}$ from transistmian highway, $9^{\circ} 25^{\prime} \mathrm{N}, 79^{\circ} 40^{\prime} \mathrm{W}, 500 \mathrm{~m}, 17-18 \mathrm{Feb}$. 1986, B. E. Hammel 14502, G. McPherson \& D. Roubik (MO!). Panamá: Río Tecumen, 3 Jan. 1924, P.C. Standley 29353 (AMES!). FRENCH GUIANA: Crique tigre. Bassin

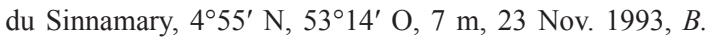
Bordenave $512(\mathrm{P}$ !). Forêt sur la rive gauche du Yaroupi, entre son embouchure et le Saut Couéki, 30 Abr. 1970, R.A.A. Oldeman T-614 (P-1!. P-2! [2 duplicates]). Camp Caiman - Asarco - Mt de Kaw, 4³1'720" N, 52 ${ }^{\circ} 13^{\prime} 386^{\prime \prime}$ W, 10 m, 17 Jan. 2000, B. Bordenave, N. Raes \& L. Betian 4961 (U!).TRINIDAD \& TOBAGO: Tobago, 6 Mar. 1911, W. E. Broadway s.n. (P-00128676!, P-00128677!; U!). Trinidad, A. Fendler 1007 (P!). Trinidad, 13 Nov. 1925, W.E. Broadway s.n. (K!). Mora fores, east of Sangre Grande, 10 Apr. 1921, E.G. Britton 2841 (NY!).BRAZIL: Pará, Parauapebas, Serra dos Carajás, entorno da Mina do Alemão; 603' 40" N, 50³2'53" W, 590 m; 15 Dec. 2019 (fl), E.R. Pansarin 1557 (LBMBP, illustration!).

Other SPECIMENS: MEXICO: Chiapas: Estación de Biología de Chajul, sobre el camino a Arroyo Miranda, 200 m, 16 $7^{\prime} 35^{\prime \prime}$ N, 9054'35" W, 12 Abr. 1997, M. Soto 8347 (AMO); same data, M. Soto 8350 (AMO); same locality, 14 Abr. 2000, M. Soto 9727 (AMO); same data, M. Soto 9729 (AMO); same locality, M. Soto 9730, S. Maldonado, L. López y P. Schlütter (AMO); Sobre la Vereda La Granja, Estación de Biología de Chajul, ca. $16^{\circ} 7^{\prime} \mathrm{N}, 90^{\circ} 54^{\prime} \mathrm{W}$, 200 m, 15 Abr. 2000, M. Soto 9731 \& P. Schlütter (AMO). Estación de Biología de Chajul, sobre el camino a Arroyo Miranda, S. Maldonado s.n., L. López \& P. Schlütter (AMO). BELIZE: Corozal: P.H. Gentle 328 (F-713628). Toledo: Broken Cohune Ridge, between Orange Point and Moho River, 28 Apr. 1952, P.H. Gentle 7673 (MEXU-511492).

Distribution: A broadly distributed species found in Mexico, Belize, Guatemala, Honduras, Nicaragua, Costa Rica, Panama, French Guiana, Trinidad and Tobago, and Brazil (Fig. 6B).

EXTENT OF OCCURRENCE: 4,874,345.189 km².

Vanilla hartii plants are easily recognized by the opaque, dark green stems, with internodes usually longer than the leaves, elliptical, acuminate leaf blades, whitish flowers, the lip gibbous at the base, apically with the dentate to denticulate margin, the callus inconspicuously papillose, apically triangular, fleshy, thickened and raised. It is also a typical species in the shady understory of rain forests.

Portères (1951a) described Vanilla leprieurii Portères from a specimen collected in the French
Guiana. The protologue stated that the vegetative and floral morphology of $V$. leprieurii are very similar to that of $V$. hartii, but $V$. leprieurii can be distinguished by the penicillate callus of the lip with denser nervation, flesher and with more imbricate scales, and the apex of the lip is more emarginated, apiculate and plicate. Soto Arenas \& Cribb (2010) and Soto Arenas \& Dressler (2010) considered the species a synonym of $V$. hartii. However, Szlachetko, Veyret, MytnikEjsmont, Sawicka, Rutkowski \& Baranow (2012) and Szlachetko, Nowak, Baranow \& Kolanowska (2016) recognized $V$. leprieurii as a distinct species, without arguing how it is to be distinguished from $V$. hartii. Furthermore, Szlachetko et al. (2016) include Vanilla inornata Sambin \& Chiron under the synonym of $V$. leprieurii. Nevertheless, we agree with the previous interpretation by Soto Arenas and Cribb (2010) and Soto Arenas and Dressler (2010) that the type specimen of $V$. leprieurii is indistinguishable from $V$. hartii, and are therefore synonyms. Whereas $V$. inornata, with its green, slightly granulose (vs. dark green, glabrous) stem, narrowly lanceolate (vs. elliptic) leaves, yellowish-green, larger flowers (vs. white, smaller), crenulate-undulate (vs. denticulate) lip margin, is a completely different species.

Soto Arenas used the name "Vanilla perplexa Soto Arenas" on a specimen from Costa Rica that he later determined as $V$. hartii at MO (Grayum \& Ray 7998). The name was never formally published and its use should be avoided.

3. Vanilla inodora Schiede, Linnaea 4: 574. 1829. Fig. 10-13, 14A.

TYPE: [MEXICO]. "Baynilla de puerco Misantlensium. Species distinctissima. Hab. Misantlae. Schiede s.n. (lectotype designated here: W-ESP70160!, Fig. 10; isolectotypes: W-ESP70159!, Fig. 11b; BM000062769!, Fig. 11C; LE-00001364!).

Syn.: Vanilla pfaviana Rchb.f., Gard. Chron., n.s., 20: 230. 1883.

TYPE: "MEXICO” [COSTA RICA]: R. Pfau 269 (holotype: W!; Fig. 11D).

Syn.: Vanilla preussii Kraenzl., Notizbl. Bot. Gart. Berlin-Dahlem 7: 320. 1919.

TYPE: GUATEMALA. Bei der Planzung El Baúl im Buschwald, Heisst bei den Eingeborenen 


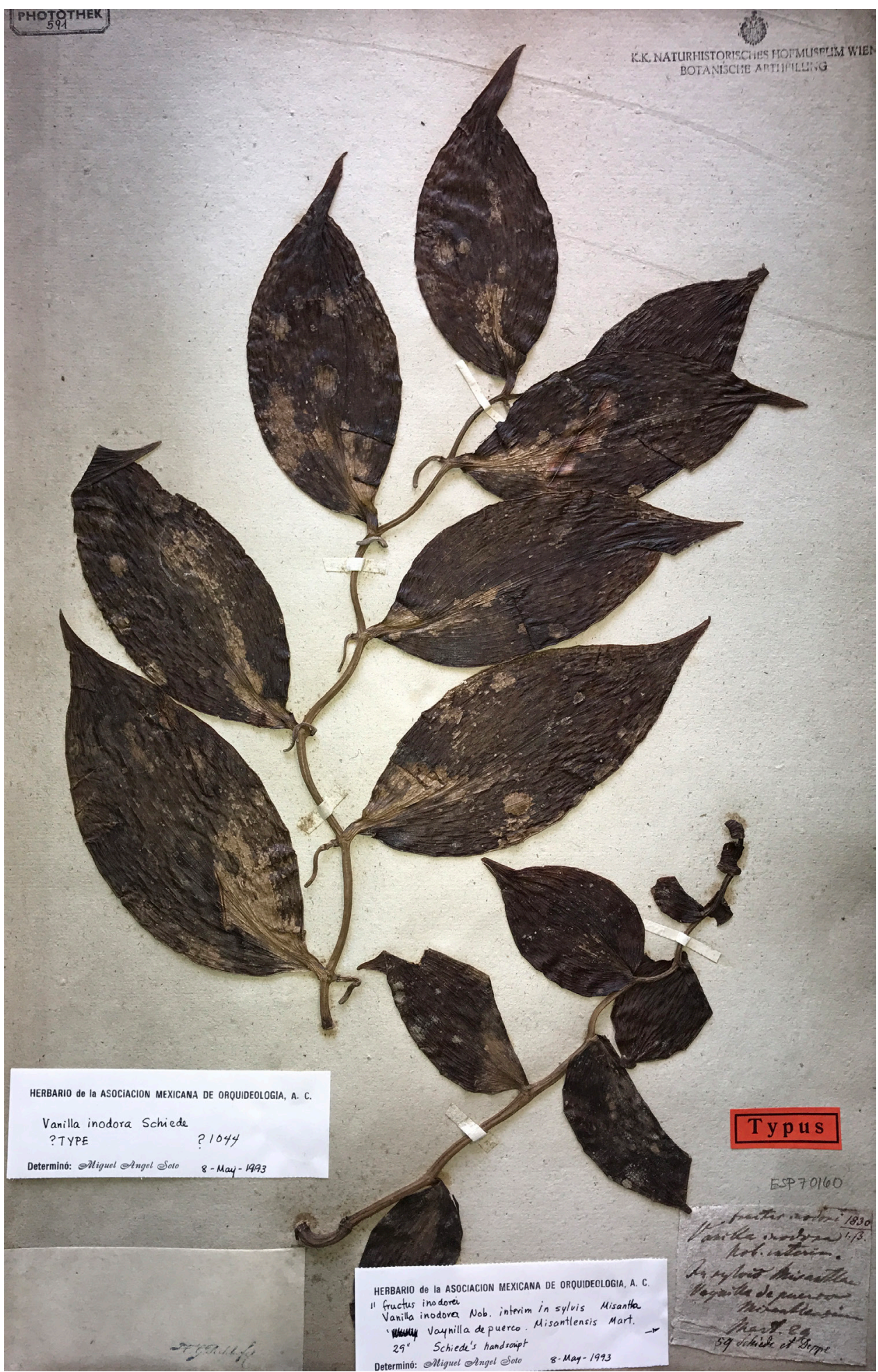

FIGURE 10. Lectotype of Vanilla inodora Schiede, Schiede s.n. (W-ESP70160). Photograph by APK. 


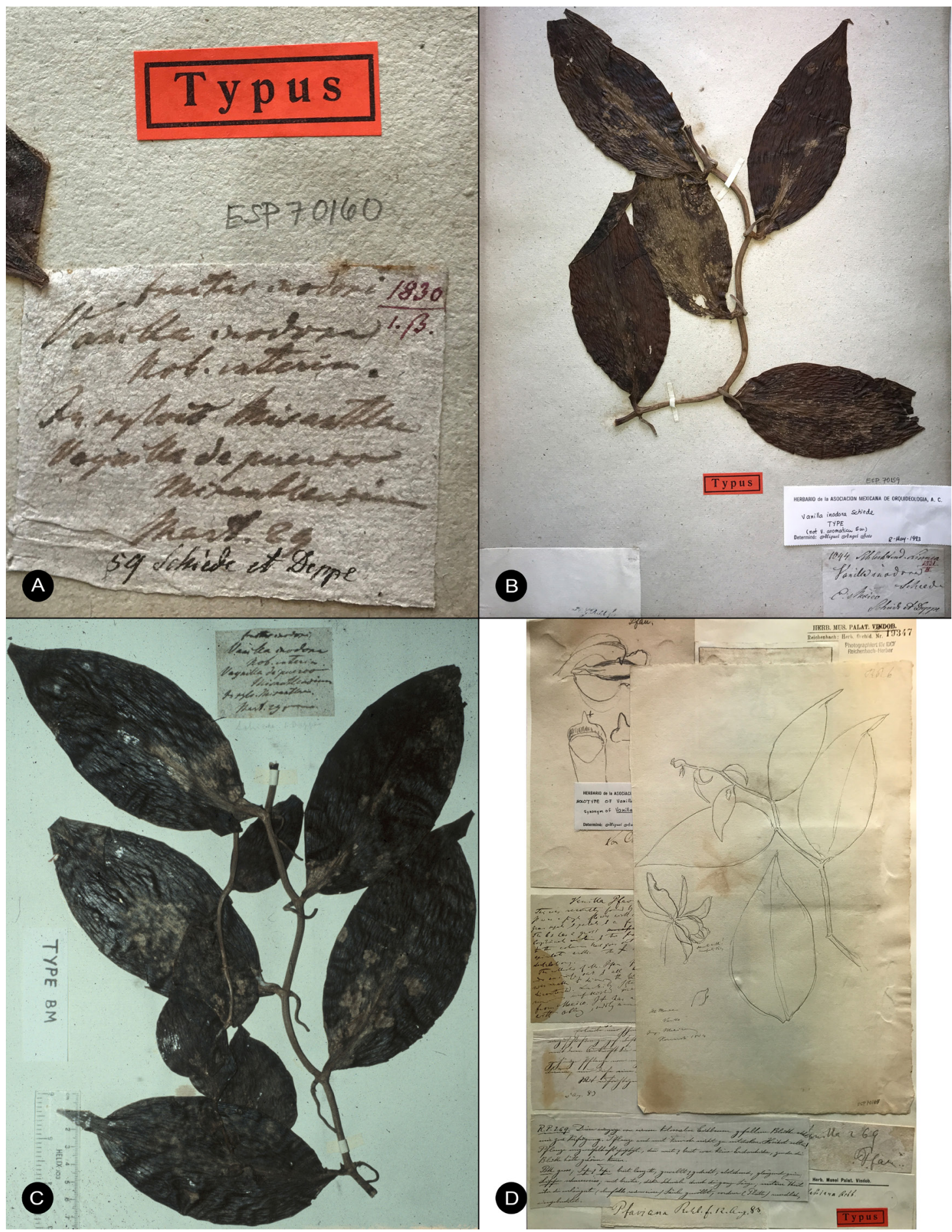

FIGURE 11. Type material of Vanilla inodora Schiede. A. Handwritten note by Schiede on the lectotype of $V$. inodora Schiede (W-ESP70160). B. Isolectotype of $V$. inodora at W-ESP70159. C. Isolectotype of $V$. inodora at BM-000062769. D. Illustration of type of $V$. pfaviana Rchb.f. at W. Photographs by APK (A, B, D) and Miguel Soto Arenas (C). 
"Vainilla silvestre", Preuss n. 1445 (holotype: B, destroyed).

Syn.: Vanilla rebecae Archila \& Chiron, Richardiana, N.S. 3: 74. 2019, syn. nov.

TYPE: GUATEMALA. Alta Verapaz: municipio de Cobán, $800 \mathrm{~m}$ asl, col. Fredy Archila, flowered in Sept. 2010, FA-sn (holotype: BIGU, illustration!).

Hemiepiphytic herb, leafy vine, up to several meters high. Stems branching, terete, fleshy, up to $6 \mathrm{~mm}$ in diameter; internodes 4-7 cm long. Aerial roots velamentous, semicylindric, one per internode emerging opposite to the leaf, $1.5-4.0 \mathrm{~cm}$ long. Leaves subsessile; blade elliptic, acuminate, membranaceous to chartaceous, 9-21 × 4.5-7.5 cm. Inflorescence lateral, similar to the vegetative shoot, axillary, erect, racemose, up to $30 \mathrm{~cm}$ long, with successive flowers, 2-3-opened simultaneously; peduncle up to $3 \mathrm{~cm}$ long, rachis terete, internodes up to $5 \mathrm{~cm}$ long; floral bracts similar to the leaves in shape, sessile, lustrous, 3-12 × $1-6 \mathrm{~cm}$, basal one, and apical ones shorter. Ovary (plus pedicel) terete, $4.5-6.0 \mathrm{~cm}$ long in open flowers, $3-4 \mathrm{~mm}$ in diameter, straight to curved at the apex. Flowers with ovary dark green, sepals and petals pale green to yellowish, lip white, apex lightly greenish and column white, with the stigma yellowish; petals and sepals more or less flat at anthesis, turning conspicuously reflexed with undulate margins, apically deeply recurved, sometimes become uncinate, and lateral sepals dextrorse, rolled outwards. Dorsal sepal narrowly elliptic, obtuse to acute, 11-veined, 3.8-5.0 × 1.1-1.6 cm. Lateral sepals narrowly elliptic to oblanceolate, obtuse, 9-veined, 3.5$4.5 \times 1.0-1.6 \mathrm{~cm}$. Petals elliptic to narrowly lanceolate, acute to obtuse, 10-veined, $4.0-4.7 \times 0.9-1.1 \mathrm{~cm}$, abaxially sulcate along the midvein. Lip fused to the column base along the margins for ca. $5 \mathrm{~mm}$, bell-shape, trilobed; when spread out 2.8-3.6 $\times 2.7-3.4 \mathrm{~cm}$; the base unguiculate, the claw $4 \times 4 \mathrm{~mm}$; the blade cucullate, when spread out approximately pandurate in outline; the lateral lobes broad, rounded, incurved forming a gullet around the column, margins not overlapping; the midlobe spreading, subcuadrate, deeply emarginated, lightly recurved, margins undulate, $1.2-1.7 \times 1.3-1.9$ $\mathrm{cm}$; the disc, the midlobe and part of the disc with a massive, ovate, fleshy, elevated, cushion-like callus, 16$20 \mathrm{~mm} \times 5-8 \mathrm{~mm}$; the disc basally with a sulcate callus attenuating towards the center of the blade, then rises apically forming a massive, ovoid, fleshy, low cushion. Column subterete, arcuate, $2.2-3.0 \times 0.4-0.5 \mathrm{~cm}$, wider at the apex, ventrally canaliculate, apex obtuse. Stigma transversely oblong with thickened margins. Rostellum inconspicuous. Anther broadly cordiform, attached to the clinandrium, and forming together with it, a couple of lateral horn-shaped projections, $5 \mathrm{~mm}$ wide, clinandrium undulate. Pollen not forming a clear pollinarium but a sticky, tow soft, sticky granular mass. Fruit cylindric, attenuate at both ends, non-aromatic, $18.0 \times 0.8 \mathrm{~cm}$.

Specimens Studied: MeXiCO. Chiapas: Libertad Acacoyagua, 01 Jun. 1948, E. Matuda 17912 (AMES!). Guerrero: System of Teotepec, near San Vicente, N.E. of Atoyac, 850 m, 10 Jan. 1933, O. Nagel 1984 (AMES51815!; AMES-41396!). Puebla: Vicinity of Puebla, Venant des sierras, 8 Déc. 197, B.G. Arsène 1682 (NY!). Veracruz: Hacienda de Java, 18 May 1841, Liebmann 295/296 (W13537!; W-13538!). Mirador, Aug. 1841, Liebmann 294 b (P00128666!). Zacuapan, Jun. 1919, C.A. Purpus 8481 (NY!; AMES!). Near Zacuapan, 12 Feb. 1932, 96 $52^{\prime}$ W, $19^{\circ} 12^{\prime}$ N, ca. 900 m, O. Nagel 2683 (AMES-41475!). Region of Zacuapan, near Rancho Viejo, climbing on tree trunks, ca. 700 m, 10 Jul 1935, C.A. Purpus 4876 (AMES-51843!). Region of Zacuapan, 8 Oct. 1935, ca. 800 m, C.A. Purpus 5045 (AMES-51838!). Hueytamalco, Campo experimental "Las Margaritas" (INIFAP), 23 Abr. 2008, G. Ibarra Manríquez et al. 5600 (NY!). Misantla et Tlapacoya, Jun. 1866, L. Hahn s.n. (P-00128662!; P-00128665!). Veracruz, foret humide du Chiguihuit, 16 Aug. 1866, L. Hahn 271. (P00128663!; P-00128664!). BELIZE. Toledo District: Gracie Rock, Sibun River, 01 May 1935, P.H. Gentle 1672 (AMES42338!). Near river beyond Columbia, 31 Jan. 1947, P.H., Gentle 6152 (NY-00984259!, NY-00984260!). Near river beyond Columbia, 31 Jan. 1947, P.H. Gentle 6152 (F1599367!). Toledo. In acahual, near Ocotal Pine Ridge, $3 \mathrm{mi}$ in trail from $7 \mathrm{mi}$, Punta Gorda-San Antonio Road, 20 Jan. 1950, P.H. Gentle 6957 (F!). GUATEMALA. Baja Verapaz: Wald in Paujal, 1000 m, Apr. 197, H. von Türckheim II 1764 (US-825825!). HONDURAS. Colon: Guarunta, Wispernini Camp, 75-100 ft., Mar. 1938, C. \& W. von Hagen 1352 (NY!). COSTA RICA. San José: Vicinity of El General, 1130 m, Feb. 1936, A. Skutch 2592 (AMES-44231!; AMES44232!; AMES-44233!; NY!; USF!; K!). Puntarenas: Osa, Fila Costeña, Río Piedras Blancas, cerca de la casa, Cerro Anguiciana, Fila Cruces, $8^{\circ} 49^{\prime} 02^{\prime \prime} \mathrm{N}, 83^{\circ} 11^{\prime} 23^{\prime \prime} \mathrm{W}, 900 \mathrm{~m}$, 10 Dec. 1993, R. Aguilar 2726 (FLAS!). Tarrazú, cuenca del río Naranjo y Paquita, cerca de San Isidro, sector NE, cabeceras Quebrada Gracias a Dios, 9 $9^{\circ} 31^{\prime} 25^{\prime \prime} \mathrm{N}, 84^{\circ} 02^{\prime} 30^{\prime \prime}$ W, $500 \mathrm{~m}$ (CR-260560!). Puntarenas: Garabito, Jacó, Tárcoles, ca. 7 km camino a Bijagual desde el cruce de la 


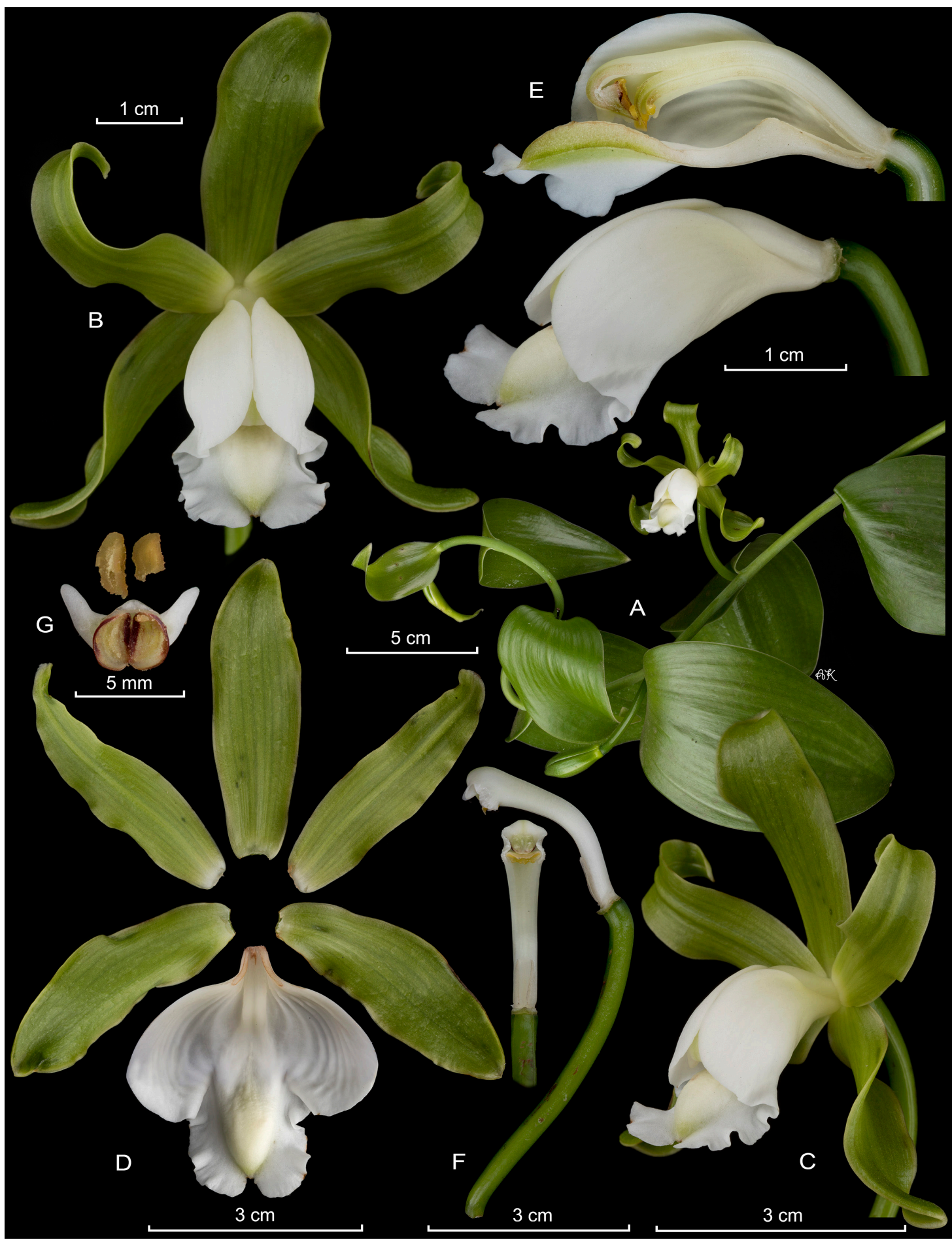

FiguRE 12. Lankester Composite Dissection Plate (LCDP) of Vanilla inodora. A. Inflorescence with foliaceous bracts. B. Flower, frontal view. C. Flower, side view. D. Dissected perianth. E. Lip and column lateral view. F. Column, ventral and lateral view. G. Anther cap and pollinia. By APK based on Karremans 7713 (JBL-spirit). 


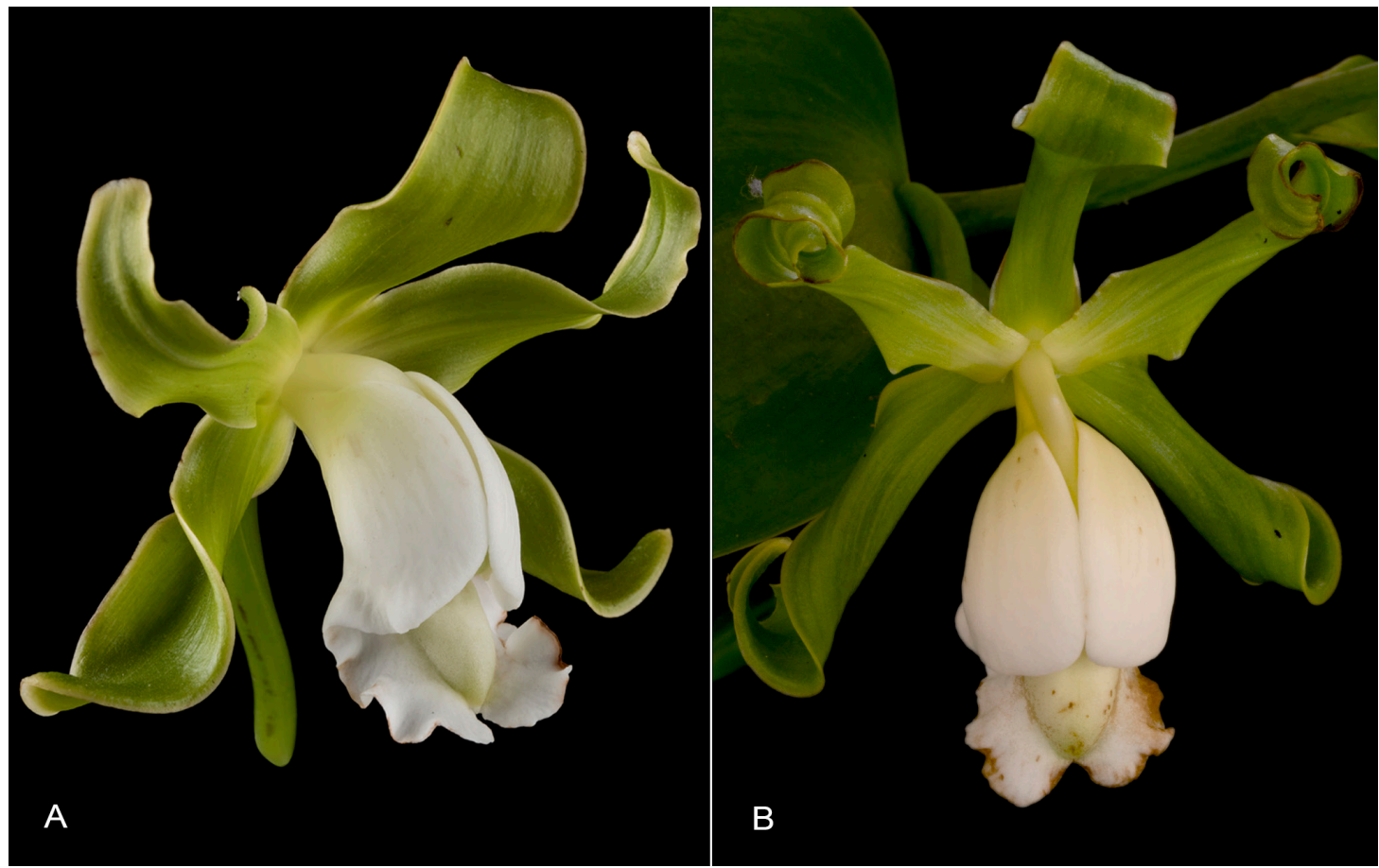

Figure 13. Flowers of Vanilla inodora. A. Flower on the day of anthesis, with flattish perianth segments, A.P. Karremans 7708 (JBL-spirit). B. Flower a few days after anthesis, with conspicuously twisted perianth segments, A.P. Karremans 7701 (JBL-spirit). Photographs by APK.

costanera, 9०44'38.33" N, 84³4'49.70" W, 448 m, 4 Feb. 2017, A. Karremans 7713 \& M. Contreras-Fernández (JBL-spirit!; Fig. 12). San José: Pérez Zeledón, Paramo, La

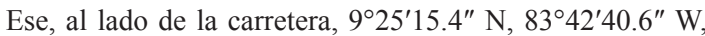
1080 m, 1 Feb. 2017, A.P. Karremans 7708, M. Cedeño, \& I. Chinchilla (JBL-spirit!; Fig. 13A). Coto Brus, San Vito, Fila Tigre, orillas de la calle, poco después del Río Cotón, $8^{\circ} 58^{\prime} 47^{\prime \prime} \mathrm{N}, 82^{\circ} 56^{\prime} 38^{\prime \prime} \mathrm{W}, 1160$ m, 31 Ene. 2017, A.P. Karremans 7701, M. Cedeño, \& I. Chinchilla (JBL-spirit!; Fig. 13B). PANAMA. Bocas del Toro: Epiphyte, flower pale green, Big Bight, Vicinity of Chiriquí Lagoon, 27 Oct. 1940, H. von Wedel 2880 (AMES!). Chiriquí: camino hacia la finca Landau, N.E. del campamento de Fortuna (sitio de prese) 1,100 m, 9 Jun. 1976, M.D. Correa A.N. Escobar \& R. Mendoza 2153 (NY!).

Distribution: Mexico, Belize, Guatemala, Nicaragua, Costa Rica and Panama (Fig. 14A).

EXTENT OF OCCURRENCE: 872,447.770 km².

The identity of Vanilla inodora has been historically somewhat obscure. The protologue is uninformative and none of the original materials collected by Schiede in Misantla, Mexico are known to bear flowers. Therefore the application of the name has followed an exclusion process rather than direct determination. The large, broad leaves and distinct foliaceous bracts clearly indicate that $V$. inodora belongs to Vanilla subgen. Vanilla, known as the membranaceous group. Soto Arenas \& Dressler (2010) argued that as only one species of the group was known to grow in Mexico, other possibilities had been excluded. Even though we here extend the range of $V$. mexicana Mill. well into northern Central America and can't rule out the possibility that it may be recorded in Mexico in the future, we agree in their interpretation of $V$. inodora. The notoriously large foliaceous bracts of $V$. inodora that are clearly visible in the type specimens are absent in $V$. mexicana, distinguishing the two species. It has been unclear where the type specimen of $V$. inodora is kept. We found original material with the annotation "Vanilla inodora Vaynilla de puerco Misantlensium" in Schiede's handwriting at W and BM, and two more specimens at W and LE bearing the annotation "Vanilla inodora Schiede". We select one of the specimens at W, bearing Schiede's annotation, as lectotype and the other three specimens as isolectotypes. 

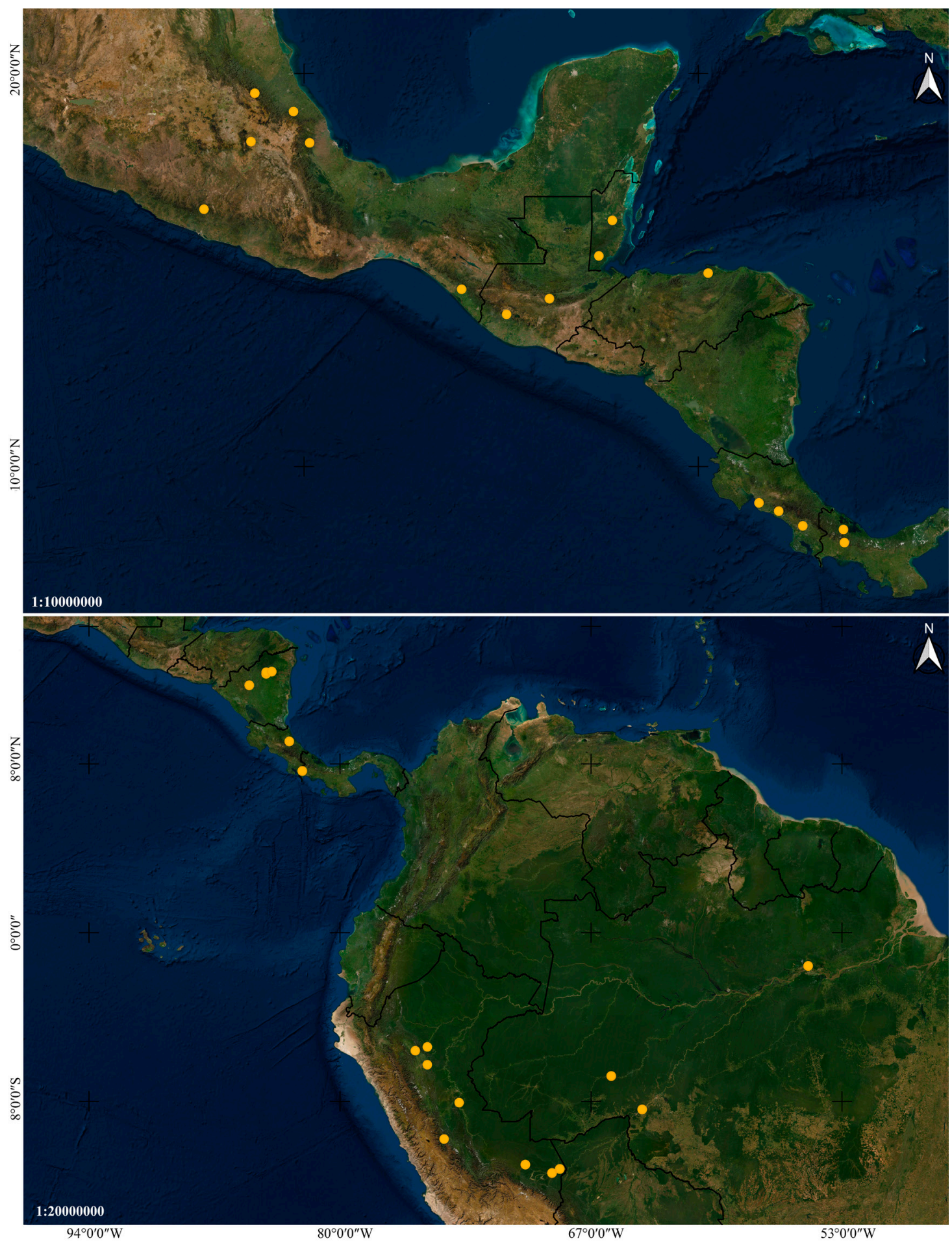

FIgURE 14. Distribution maps of Vanilla species based on studied specimens. A. Vanilla inodora Schiede. B. Vanilla karenchristianae Karremans \& P.Lehm. Images by IC. 
We agree with Soto Arenas \& Dressler (2010) that the name Vanilla pfaviana is conspecific with $V$. inodora. The type specimen at $\mathrm{W}$, the illustration of the type, and the original description by Reichenbach, who mentioned the twisted green tepals and the emarginate lip with a long thick cushion, fit $V$. inodora well. We also agree with the authors in placing Vanilla preussii under the synonymy of $V$. inodora. Even though the type specimen was lost, the foliaceous floral bracts, undulate sepals, and the apically emarginate lip with an elevated disc, as mentioned in the protologue, match $V$. inodora. The recently described Vanilla rebecae from Guatemala is here also considered as a synonym of $V$. inodora. It was said to differ from $V$. inodora by having larger flowers, flat sepals and petals, an elliptic dorsal sepal, lateral sepals strongly veined, petals with rounded apex, lip slightly trilobate, with an apically rounded midlobe, ovary somewhat curved geniculate, and a shorter fruit. However, the floral shape and dimensions cited for $V$. rebecae match the variation documented in $V$. inodora. Other allegedly distinguishing features such as the wider, flat sepals and petals and extension of the lip lobes are variable features even within a single flower of $V$. inodora; varying from wide, flat sepals and petals and non-extended lip lobes at the time of anthesis, to seemingly narrower, conspicuously twisted sepals and petals and extended lip lobes a few days later (Fig. 13).

\section{Vanilla karen-christianae Karremans \& P.Lehm.,} Orchids (West Palm Beach) 87: 305. 2018. Fig. 14B, 15-17.

TYPE: COSTA RICA. Puntarenas: Corredores. Canoas, 27 Sept. 2017, A.P. Karremans et al. 8087 (holotype: USJ!; isotypes: JBL-spirit!; CR!; Fig. 15, 17A).

Syn.: Vanilla uncinata Huber ex Hoehne, Arch. Inst. Biol. (São Paulo) 8: 269. 1937, nom. nud., syn. nov. TYPE: BRAZIL. Cultivado no Horto Botanico od Museu Paraense, fl. em Aug. 1906, vinda do Rio Purús, de onde foi trazida pelo Dr. A. Goeldi em data ignorada. J. Huber s.n. (MG-007302!, Fig. $16 \mathrm{~A})$.

Syn.: Vanilla uncinata Huber ex Hoehne, Fl. Brasilica 12(2): 209. 1945, nom. nud., syn. nov.
SYNTYPES: BRAZIL. Cultivado no Horto Botanico od Museu Paraense, fl. em Aug. 1906, vinda do Rio Purús, de onde foi trazida pelo Dr. A. Goeldi em data ignorada. J. Huber s.n. (MG007302!). Pará: Río Branco de Óbidos, entre Santo Antonio et Salidão, mata de terra firme, 14 Sept. 1927, fl. Escandente; fl. verde, labello branco com pequeno signal amarellado. W.A. Ducke s.n. (RB19446/00260182!; illustration in Fl. Brasilica 12(2): t. 2; Fig. 16B).

Hemiepiphytic, branching, leafy vine, up to several meters high. Stems dark to olive green, flexuous, subterete, with a conspicuous groove along the internodes, one per internode emerging laterally to the leaf, $6-7 \mathrm{~mm}$ in diameter; internodes, 6-12 cm long. Aerial roots semicylindric, ca. 2-3 $\mathrm{mm}$ in diameter. Leaves subsessile; blade obliquely ensiform, shortly acuminate, conspicuously recurved, sometimes becoming uncinate, margins slightly revolute, coriaceous, 9-23 $\times 1.1-2.5$ $\mathrm{cm}$. Inflorescence lateral, simple, axillary, erect, racemose, producing many flowers, more than 25 successive flowers per raceme, 1-opened simultaneously; peduncle abbreviated, fleshy, subterete, ca. $1 \mathrm{~cm}$ long; rachis up to $5 \mathrm{~cm}$ long. Floral bracts sessile, small, ovate, obtuse, concave, fleshy, ca. 4-15 mm long, with an external nectary close to the base, aligned with the midevein. Flowers ephemeral, segments not spreading, basal half of the ovary white, apical half green, tepals light green, shiny, lip white with the side veins and appendages dull yellow, penicillate callus white, column white; fragrance weakly citric. Ovary subterete, smooth, arcuate, 27-43 × 3-4 mm; with three external, apical nectaries, aligned with the mid-vein of each sepal. Dorsal sepal oblanceolate, acute, somewhat concave, fleshy, ca. 7-veined; 39-54 × 9-13 mm. Lateral sepals obliquely oblanceolate, acute, fleshy, ca. 12 veined, $37-54 \times 10-14 \mathrm{~mm}$. Petals obliquely linear to lanceolate, acute, somewhat arcuate, with a conspicuous, elevated dorsal keel; ca. 7-veined, $37-52 \times 5.5-10 \mathrm{~mm}$. Lip fused to the column along the margins for ca. $2.5 \mathrm{~cm}$, tubular, trumpet-shaped, concave, inflated near the middle, becoming deeply saccate, shallowly trilobed; when spread out 39-48 $\times$ 20-35 mm; unguiculate, the claw papillose, ca. 


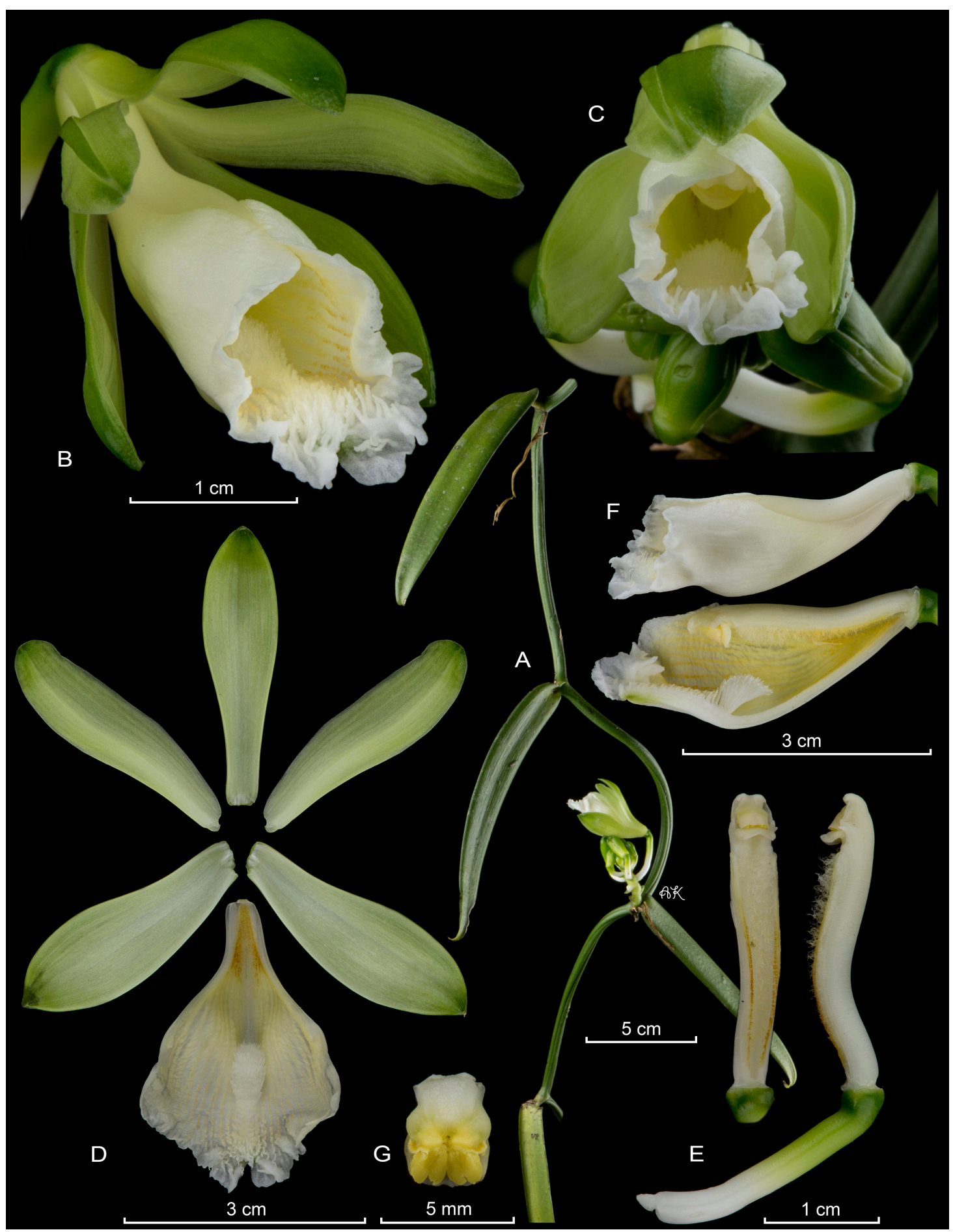

Figure 15. Lankester Composite Dissection Plate (LCDP) of Vanilla karen-christianae Karremans \& P.Lehm. A. habit. B. inflorescence. C. Flower. D. Dissected perianth. E. Column and lip lateral view. F. Column in ventral and lateral view. G. Anther cap and pollinia. Photographs by APK based on Karremans 8087 (JBL, CR, USJ). 
$1 \mathrm{~cm}$ long; the blade approximately obovate in outline, ca. 20-veined, the veins thickened forming low, papillose to verruculose keels, taller towards the apex; the lateral lobes obtuse, incurvated, margins entire to lightly crenate; the midlobe bilobed to emarginate, with a recurved tip, margins irregularly crenate, undulate; penicillate callus 2.5-3.0 $\mathrm{cm}$ from the base, $6-7 \times 3 \mathrm{~mm}$; made up of reclined, flabellate, densely lacerate to lacinate scales; extending for about $15 \mathrm{~mm}$ to the apex, ca. $3.5 \mathrm{~mm}$ wide, gradually lowering towards the apex. Column suterete, obfalciform, 25-39 $\times 4-5 \mathrm{~mm}$, from similar width along, ventrally densely covered by trichomes below stigma, apex with three wings. Stigma trilobed, lateral lobes erect, small, $2 \times 1 \mathrm{~mm}$. Rostellum a large, transversely oblong, convex. Anther basally hinged to the column, movable, subcuadrate, 4-6 × 3-4 mm. Pollen not forming a clear pollinarium but a sticky, granular mass. Fruits $6.7-12 \mathrm{~cm}$, cylindrical, fragrant.

SPECIMENS STUDIED: NICARAGUA. Matagalpa: La Dalia, 13.058 N, 85.72 W, G. Laube s.n. (JBL-photograph!; Fig. 17D). Zelaya: Cerro Waylawas, $10 \mathrm{~km}$ south of Siuna; 250 m, 5 Jun. 1978, D. Neill 4219 (MO!). Cerro Kana Coperna, $30 \mathrm{~km}$ east of Siuna, $250 \mathrm{~m}, 17$ Jun. 1978, D. Neill 457 (MO!). Municipio de Siuna, Río Matis. Elev. menos de 100 m, 16 Set. 1982, F. Ortiz 172 (MO!). Cerro Waylawas, ca. $13^{\circ} 39^{\prime} \mathrm{N}, 84^{\circ} 48-49^{\prime} \mathrm{W}, 100-268 \mathrm{~m}$; sheer dog tooth limestone peak and plain on E side of peak, 16 Mar. 1978, W.D. Stevens 7385 (MO!; AMO!). COSTA RICA. Puntarenas: Corredores. Canoas, floreció en cultivo de P. Lehmann, 16 Abr. 2017, A.P. Karremans 8123 (JBLspirit!). Limón: Siquirres, Germania, entre La Herediana y La Alegría, cercanías del río Vueltas, Finca Las Brisas, $10^{\circ} 07^{\prime} 48.34^{\prime \prime} \mathrm{N} 8^{\circ} 36^{\prime} 15.86^{\prime}$ 'W, 245 m, Ernesto Carman legit, floreció en cultivo el 25 de Oct. 2020, A.P. Karremans 8356 (JBL-spirit!, Figs. 17C, 18). PERU. Ucayali: Prov. Coronel Portillo, Dtto. Iparia, Aguajal comunidad Galilea, Reserva Comunal El Sira (zona de amortiguamiento), -9.13197 -74.4965, 175 m, 15 Mar. 2015, J. Janovec, J. Ushinawa, H. Behar 4009, 4006 (MOL!). Madre de Dios: Prov. Tambopata, carretera Cusco km 37.5 comunidad mercedes, aguajal mercedes, $-12.695-69.4693,200-250$ m, 7 Sep. 2007, J. Householder 14, A. Balarezo \& J. Huinga (USM!, Fig. 17B); Rio alto madre de dios, boca manu, $2 \mathrm{~km}$ north of local school, aguajal boca manu, -12.2566 -70.898, 280-320 m, J. Householder 941, A. Balarezo \& J. Huinga (USM!). Junin: prov. Chanchamayo, Fundo la Génova, $11^{\circ}$ 6'7.17'S 75²0'59.73"O, $1100 \mathrm{~m}$, 29 Oct. 2016, A. Damián \& Estudiantes Botánica UCSUR
905 (USM!); Prov. Chanchamayo, La Merced, cerca al Puente Paucartambo, Jun. 2018, D. Aliaga s.n. (USM!). San Martin: Prov. Picota, Dtto. Picota, bosque seco, 200 m Jul. 2018, A. Damián \& M. Leon 906 (USM!); Prov. San Martin, sin localidad, 2 Oct.1973, 400 m, R. Ferreyra, Rauh \& Bismarck 18265 (USM!). BRAZIL. Amazonas: vinda do Río Purús, de onde foi trazida pelo Dr. André Goeldi [3 May 1904], cultivada no Horto Botanico do Museu Paraense (Belém, Pará), fl. Ago. 1906, J. Huber s.n.(MG-007302!). Rondônia: Cachoeira de Jirau, floresta estacional semidecidual, área de influencia direta (lago), 85 m, 22 Mar. 2010, G. Pereira-Silva 15128 et al. (CEN00078538 !).

OTHER RECORDS: NICARAGUA. The photographs labeled Vanilla inodora in van den Berghe \& van den Berghe (2008), are this species.

Distribution: Broadly distributed in Central and South America, at elevations between 85 and $320 \mathrm{~m}$. Confirmed to occur in Nicaragua, Costa Rica, Peru and Brazil (Fig. 14B).

\section{EXTENT OF OCCURRENCE: 4,443,132.187 km².}

The very narrow, uncinate leaves and presence of a conspicuous tuft of appendages on the lip distinguish Vanilla karen-christianae immediately. Vanilla odorata shares such narrow leaves; however, that species has a yellowish flower, the lip is fimbriate and it lacks the appendages. Vanilla helleri A.D.Hawkes has similar appendages on the lip, but has a broader leaf and white flowers with a bright yellow lip. Vanilla insignis Ames also share this particular lip feature but that species has a much larger, spreading flower and a lacerate lip margin. The Brazilian V. capixaba Fraga \& D.R.Couto and $V$. ribeiroi Hoehne share the narrow leaves and white lip with a dense tuft of appendages, and are likely to be close relatives. The former can be easily distinguished by the non-recurved apex of the leaf, the broader, acute sepals and petals, the transversally oblong midlobe of the lip and the larger appendages disposed in distinct rows (Fraga et al. 2017). The type specimen and illustration of the latter show non-oblique lanceolate leaves, an oblong dorsal sepal, and especially a smaller, narrower lip with a prominently long-fimbriate apex, quite distinct from V. karen-christianae.

When Vanilla karen-christianae was described 


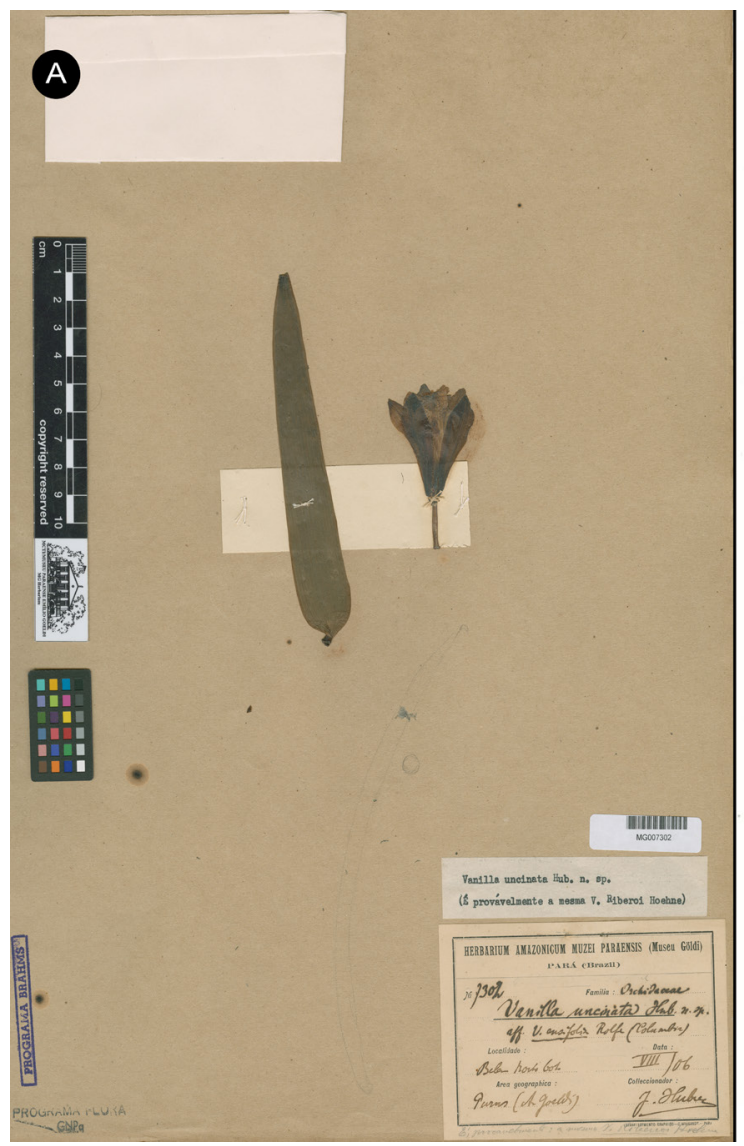

\section{B}

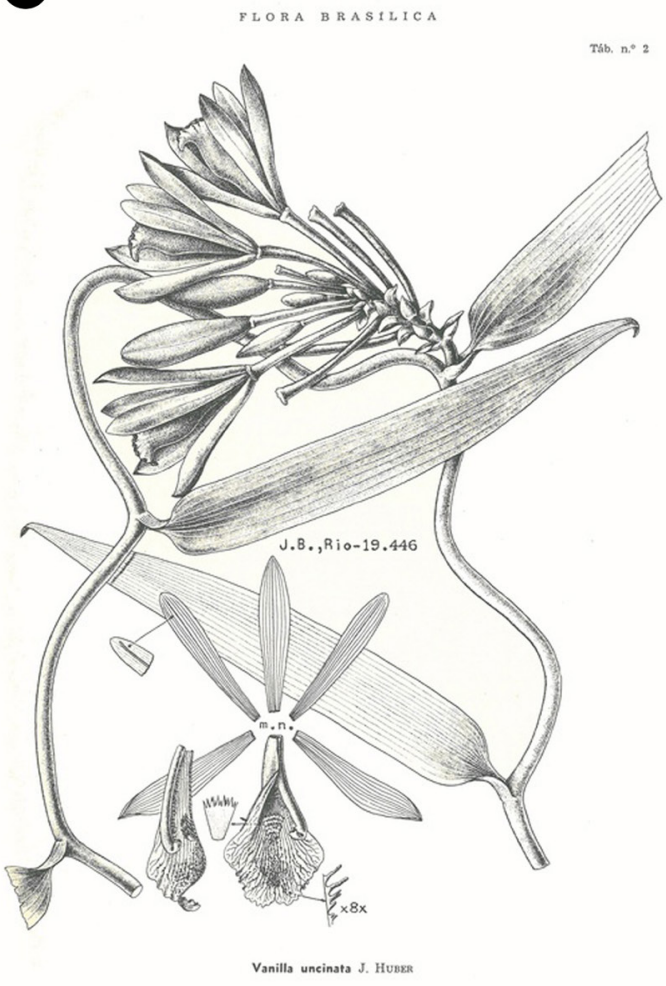

FIGURE 16. Vanilla karen-christianae as Vanilla uncinata Huber ex Hoehne, nom. nud. A. One of the materials intended as type, J. Huber s.n. (MG-007302) @ copyright of Reflora, Brazil. B. Illustration based on Ducke s.n. (RB-19446/00260182) published in Fl. Brasilica 12(2): t. 2. 1945.

no other specimens of the species were found either in Costa Rica or elsewhere. Soon after description, one of the authors of the present manuscript (AD) realized that Brazilian specimens identified as Vanilla uncinata Huber ex Hoehne, including the type, were conspecific with $V$. karen-christianae and not $V$. odorata C.Presl as previously believed. Hoehne cites the name $V$. uncinata twice; once in 1937 and then in 1945 , both times ascribing the authority to Huber. However, the name $V$. uncinata was never formally published by Huber, nor was it validly published by Hoehne. In the first case no description is provided and the author suggests it is conspecific with $V$. ribeiroi Hoehne and therefore invalid, in the second the author considers it a good species and gives an extensive description. In fact it would have fulfilled the requirements for formal publication were it not that the protologue is in Portuguese and therefore does not constitute valid publication. A Latin description became mandatory from 1935 onwards (article 39.1 in Turland et al. 2018). Therefore, even though the two names refer to the same species, V. karen-christianae is retained.

In addition to the Brazilian specimens, the species has also been found in Peru where it had been mistakenly known under the name $V$. ribeiroi (Damián \& Janovec 2018). There it inhabits the Amazonian wetlands dominated by a palm Mauritia flexuosa L.f. (locally known as "aguajales"), at 200-250 $\mathrm{m}$ in elevation in the southeast part of the country. During the preparation of this manuscript, more Costa Rican and Nicaraguan specimens of V. karen-christianae were also located. Proving that this species, initially believed to be narrowly 

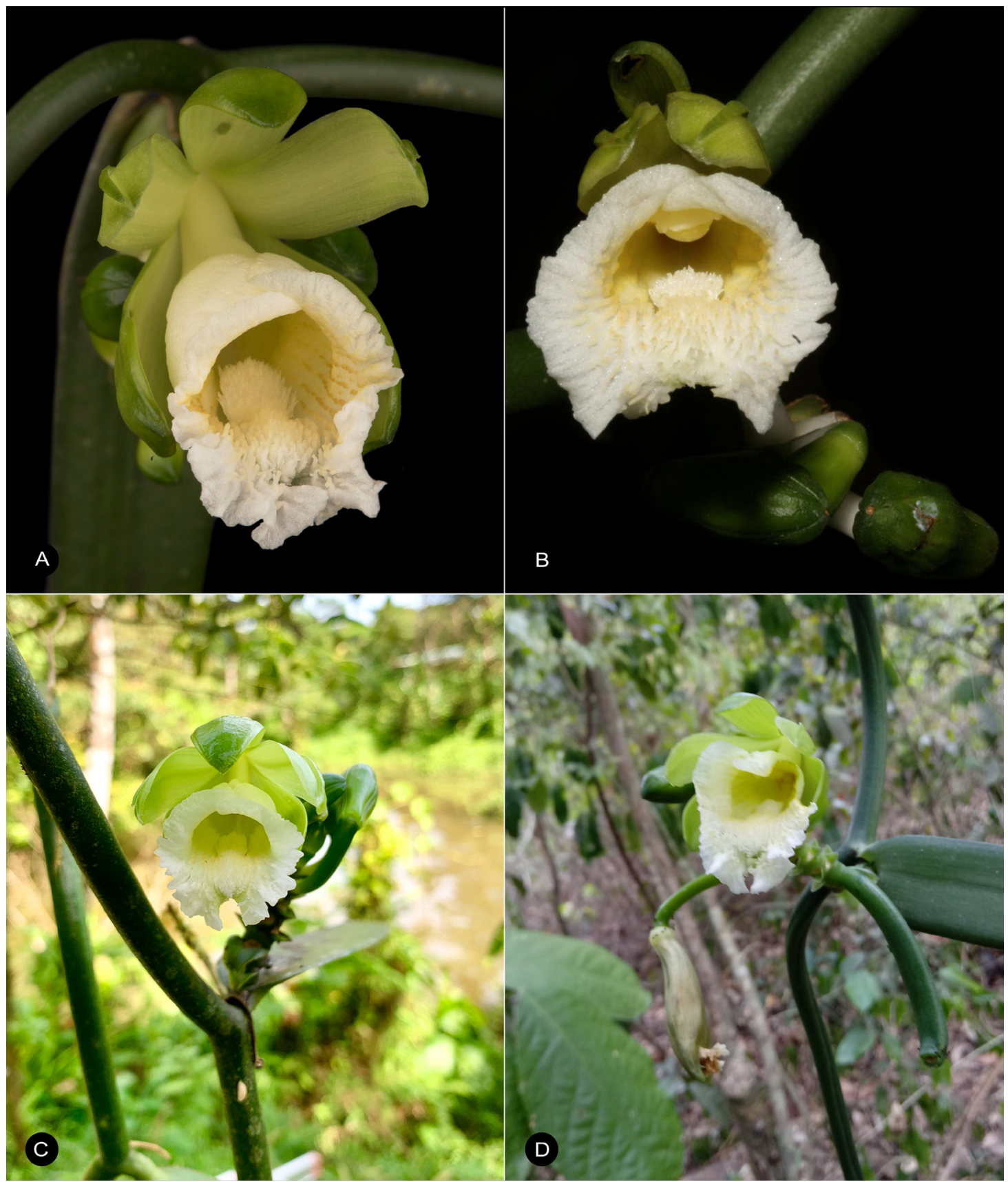

FIGURE 17. Vanilla karen-christianae flowering specimens from different localities across its distribution. A. Costa Rica, from the specimen that served as type Karremans 8087. B. Peru, Madre de Dios, Householder et al. 14. C. Costa Rica, Siquirres, in situ, Karremans 8356. D. Nicaragua, Matagalpa, in situ, Laube s.n. Photographs by the collectors kept at JBL.

distributed, actually has a very broad distribution from Nicaragua to Peru and Brazil, and is likely to show up in neighboring countries in the future, it may not be as highly threatened species as initially believed (Karremans \& Lehmann 2018). However, the species is apparently uncommon across its broad distribution and may still be a conservation priority at a local scale. 


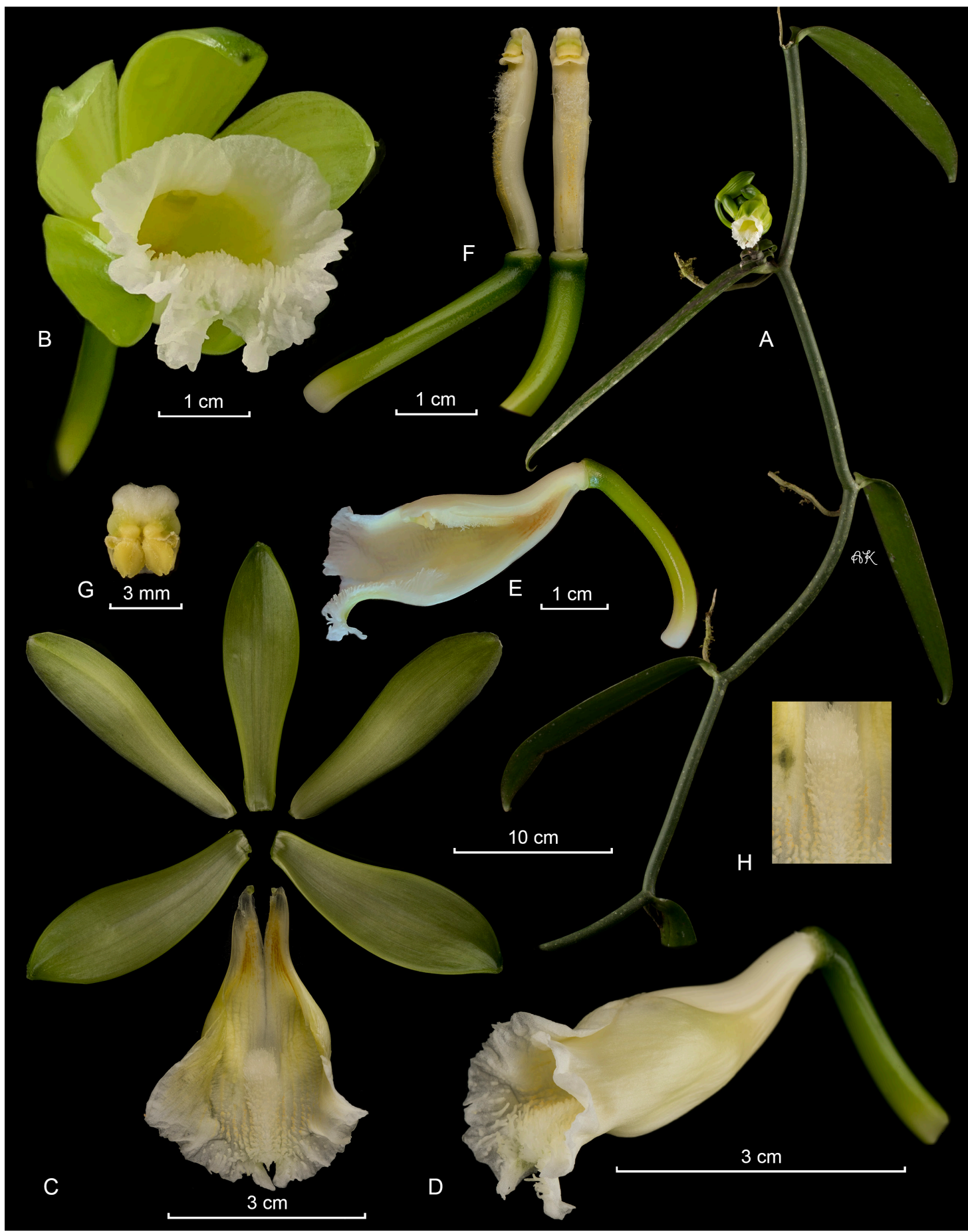

FIgURE 18. Lankester Composite Dissection Plate (LCDP) of Vanilla karen-christianae Karremans \& P.Lehm. A. Habit. B.

Flower. C. Dissected perianth. D. Column and lip lateral view. E. Column and lip in lateral view dissected. F. Column in ventral and lateral view. G. Anther cap and pollinia. H. Callus of the lip. Photographs by APK based on Karremans 8356 (JBL-spirit). 
5. Vanilla marowynensis Pulle, Enum. Vasc. P1. Surinam: 118. 1906. Fig. 19-23, 24A.

TYPE: [SURINAME: Marowijne]: Upper Marowyne River, near Poeloegoedoe, fl. July, Versteeg 623 (holotype U-L, not found; lectotype designated here: illustration of type reproduced by Pulle (1906) in Enum. Vasc. Pl. Surinam t. 4; Fig. 19).

Syn.: Vanilla cristagalli Hoehne, Arq. Bot. Estado São Paulo, n.s., f.m., 1: 125. 1944, syn. nov.

TYPE: BRAZIL. Amazonas: S. Paulo de Olivença. 23 Oct. 1931, A. Ducke s.n. (holotype: RB14512/00542720!, Fig. 20).

Syn.: Vanilla cristato-callosa Hoehne, Arq. Bot. Estado São Paulo, n.s., f.m., 1: 126. 1944, syn. nov. TYPE: BRAZIL. Amazonas: Manaus. 25 Oct. 1935, A. Ducke s.n. (holotype: RB-37468/00542721!, Fig. 21).

Syn.: Vanilla aspericaulis Sambin \& Chiron, Richardiana 15: 311. 2015, syn. nov.

TYPE: FRENCH GUIANA. Sud-est du département, berge de l'Approuague, saut grand Machikou. La plante a été observée et collectée par Vincent Pelletier en décembre 2013 dans le cadre d'une mission de prospection puis observée en fleur au Jardin botanique de Guyane le 25 Jun. 2015, V 066 VP00902 (holotype, CAY; illustration!). Cutting cultivated by P. Silland (JBL-photo!, clonotype, Fig. 22A, B).

\section{Syn.: Vanilla denshikoira Flanagan \& Ospina-} Calderón, Phytotaxa 364: 253. 2018, syn. nov.

TYPE: COLOMBIA. Guainía. Inírida, Resguardo Indígena Remanso-Chorrobocón, mediumdense riparian forest on alluvial ground c. 30 $\mathrm{m}$ from the Inírida River, Elev. 100 m, 16 Apr. 2017, N.S.Flanagan, M.Mendoza, I.T.Garcia Agapito, H.A.Mateus NSF138 (holotype: CUVC; illustration!)

Hemiepiphytic, branching, leafy vine, up to several meters high. Stems dark to olive green with minute whitish spots, rugulose, flexuous, cylindrical, 4-13 $\mathrm{mm}$ in diameter; internodes, $3.8-15 \mathrm{~cm}$ long. Aerial roots semicylindric. Leaves petiolate, generally equal or subequal to the internode; blade obovate to oblanceolate, widest above the middle, abruptly cuspidate to shortly acuminate, coriaceous; 4.5$16.0 \times 2.2-6.0 \mathrm{~cm}$, including the up to $2 \mathrm{~cm}$ long, canaliculate petiole. Inflorescence lateral, simple, axillary, erect, racemose, producing many flowers, more than 16 successive flowers per raceme, typically with 2-opened simultaneously; peduncle abbreviated, fleshy, subterete; rachis thick, up to $4 \mathrm{~cm}$ long; conspicuously shorter than the leaf. Floral bracts sessile, small, triangular to ovate, obtuse, concave, fleshy, 5-10 mm long. Flowers large, ephemeral, segments not spreading widely, ovary white, apically green, tepals greenish-cream to yellowish-orange, shiny, lip white with the apex and appendages dull yellow to orange, penicillate callus white, column white; fragrance not registered. Ovary subterete, arcuate, 35-62 mm. Dorsal sepal elliptic, oblong to narrowly oblanceolate, acute, somewhat concave, fleshy, margin thickened, especially at the apex, 52-67 $\times 10-19 \mathrm{~mm}$. Lateral sepals obliquely elliptic, oblong to narrowly oblanceolate, acute, somewhat concave and falcate, fleshy, margin thickened, especially at the apex, 46-58 $\times 12-22 \mathrm{~mm}$. Petals obliquely elliptic to narrowly oblanceolate, acute, somewhat concave and falcate, with a conspicuous, elevated dorsal, acute keel, $50-63 \times 12-17 \mathrm{~mm}$. Lip fused to the column along the margins for ca. $2.2 \mathrm{~cm}$, tubular, trumpetshaped, concave, apically trilobed, lobes apically incurved towards the appendages; when spread out $41-56 \times 28-40 \mathrm{~mm}$; shortly unguiculate; the blade approximately obovate in outline, ca. 20 -veined; the lateral lobes obtuse, margins irregular, with a few large teeth towards the midlobe; the midlobe bilobed to emarginate, with a recurved tip, margins irregularly undulate to crenate; penicillate callus $2.4 \mathrm{~cm}$ from the base, $4 \times 4 \mathrm{~mm}$; made up of reclined, flabellate, densely lacerate to lacinate scales; extending for about $2.0 \mathrm{~cm}$ to the apex of the lip, ca. $4.5 \mathrm{~mm}$ wide, gradually transforming into thick, finger-like, tuberculous, orange appendages. Column subterete, straight, $30-40 \times 3-4 \mathrm{~mm}$, from similar width along, ventrally densely covered by trichomes below stigma, apex with three wings. Stigma trilobed, lateral lobes erect, small, $2 \times 1 \mathrm{~mm}$. Rostellum large, transversely oblong, convex. Anther basally hinged to the column, movable, subcuadrate, $3-4 \times 3 \mathrm{~mm}$. Pollen not forming a clear pollinarium but a sticky, granular mass. Fruits apparently unknown, likely fragrant. 


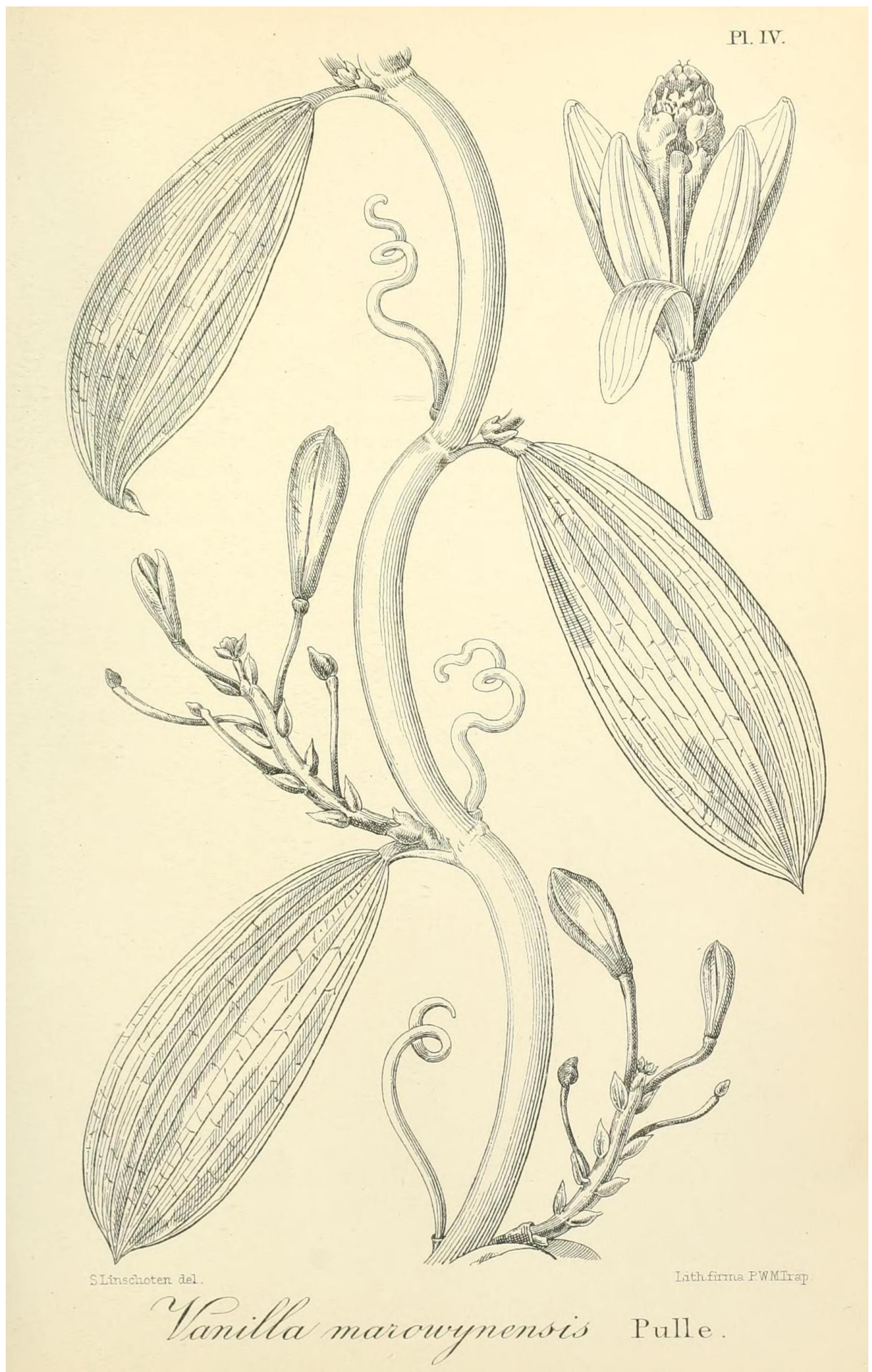

FiguRE 19. Vanilla marowynensis illustration based on Versteeg 623, reproduced by Pulle in Enum. Vasc. P1. Surinam (1906), selected here as lectotype. 

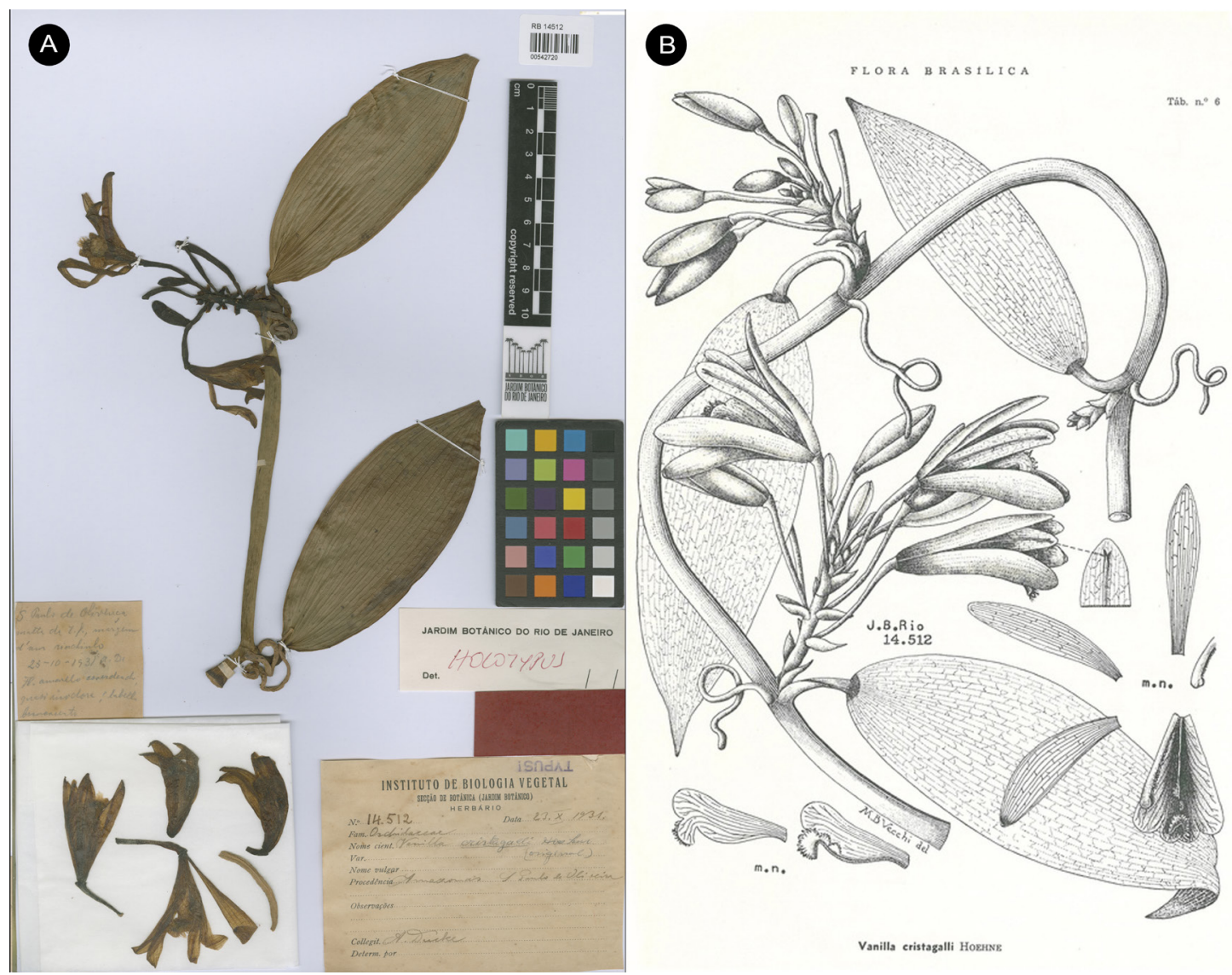

FiguRE 20. Vanilla marowynensis. A, as the holotype of $V$. cristagalli Hoehne, RB-14512/00542720 @ copyright of Reflora,

Brazil. B. Illustration of type published in Fl. Brasilica 12(2): t. 6. 1945.

Specimens STUdied: COLOMBIA. Buenaventura, en el puerto, May 1853, J.J. Triana 1614/1 (COL-000363316!). SURINAME. In montibus, qui dicuntur Nassau Border of Marowijne R., above base camp, 14 Feb. 1949, J. Lanjouw \& J. C. Lindeman 2074 (AMES-02158566!). BRAZIL. Mato Grosso: Itaúba, Resgate de Flora da UHE Colíder, 268 m, 17 May 2017, A.S. Bezerra, L. Souza Neto, J.E.L. Lessa s.n. (MBM-417193!). Mato Grosso: Itaúba, Resgate de Flora da UHE Colíder, fl., 24 Oct. 2016, M.E. Engels 4873 (MBM-417192!). Mato Grosso: Itaúba, Resgate de Flora da UHE Colíder, Lote I de supressão (Ilha), 05 Dec. 2015, fl., M.E. Engels 3913 (HERBAM, MBM, TANG, JBL-photo!, Fig. 23). BOLIVIA. Santa Cruz de la Sierra: Parque Nacional Amboro, backroads

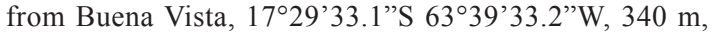
E. Brylle \& M. Nathanson s.n. (JBL, digital photograph!; Fig. 22C).

Other Specimens: COlOMBIA. Guainía. Inírida, Resguardo Indígena Remanso-Chorrobocón, mediumdense riparian forest on granite outcrop. Elev. 265 m, 15
Apr. 2017, N.S.Flanagan, M.Mendoza, l.T.García Agapito, H.A.Mateus NSF90 (CUVC).

Distribution: Broadly distributed in South America, yet apparently rare. Confirmed to occur in Colombia, Suriname, French Guiana, Brazil and Bolivia (Fig. 24A).

EXTENT OF OCCURRENCE: 4,091,165.326 km².

The name Vanilla marowynensis has remained poorly understood and mostly unused. It was described on the basis of a collection by G.M. Versteeg close to Poeloegoedoe on the Marowijne river (Fig. 22D) during the Dutch Tapanahoni expedition to the "unknown interior" of Suriname (Fig. 22E). Versteeg made the medical, botanical and zoological collections for the expedition and most of the collections were kept at Utrecht herbarium (now L). We were not able to locate the type, Versteeg 623, there or elsewhere, but the 


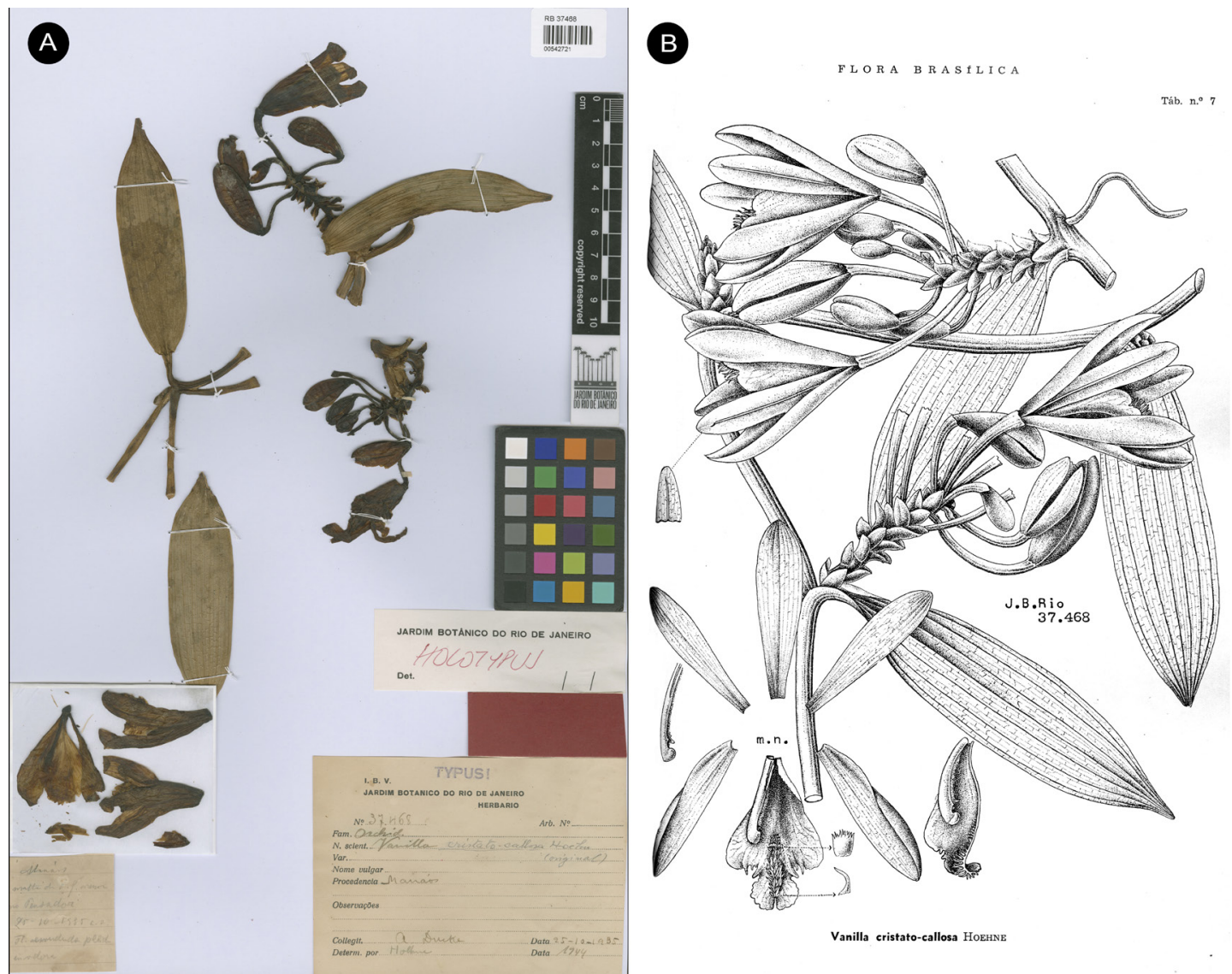

FiguRe 21. Vanilla marowynensis as V. cristato-callosa Hoehne. A. Holotype, RB-37468/00542721 @ copyright of Reflora, Brazil. B. Illustration of type published in Fl. Brasilica 12(2): t. 7. 1945.

excellent illustration of the type reproduced by Pulle (1906) in Enum. Vasc. Pl. Surinam t. 4 (Fig. 19) has here been selected as lectotype.

Soto Arenas \& Cribb (2010) placed V. marowynensis under $V$. appendiculata Rolfe and indicated that the illustration is based on an immature bud (this is not stated in the protologue). Nevertheless, several diagnostic features from the description and illustration separate the two species. According to Pulle $V$. marowynensis has petiolate, coriaceous leaves, a short, thick, axillary, multi-flowered inflorescence, bearing large flowers, oblong petals with a conspicuous dorsal keel, the lip subequal to the sepals, trilobate, with an undulate margin and dense apical appendages. From the illustration it can also be inferred clearly that the leaves are wider above the middle and then abruptly apiculate, that the tepals are thick, especially apically, non-spreading, and the lip has an irregular and incurved margin and thick, and tuberculous appendages on the mid-lobe.

Those features are not found in $V$. appendiculata, which has a terminal, few-flowered inflorescence, and very long, narrow floral segments, but they are found in two species described simultaneously from Brazil, Vanilla cristagallii Hoehne and V. cristato-callosa Hoehne. The two species were since their description suggested to be very closely related to each other and V. marowynensis, from which they were said to differ in certain details of the lip that could be better observed in the illustrations than put into words (Hoehne 1944). The dissected perianth in the illustration of $V$. cristagalli suggests a more regular lip margin and a very reduced callus with a much scarcer presence of appendages on the midlobe of the lip, but the side view of the flowers seems to contradict this interpretation and the appendages are in fact so prominent that they can be 


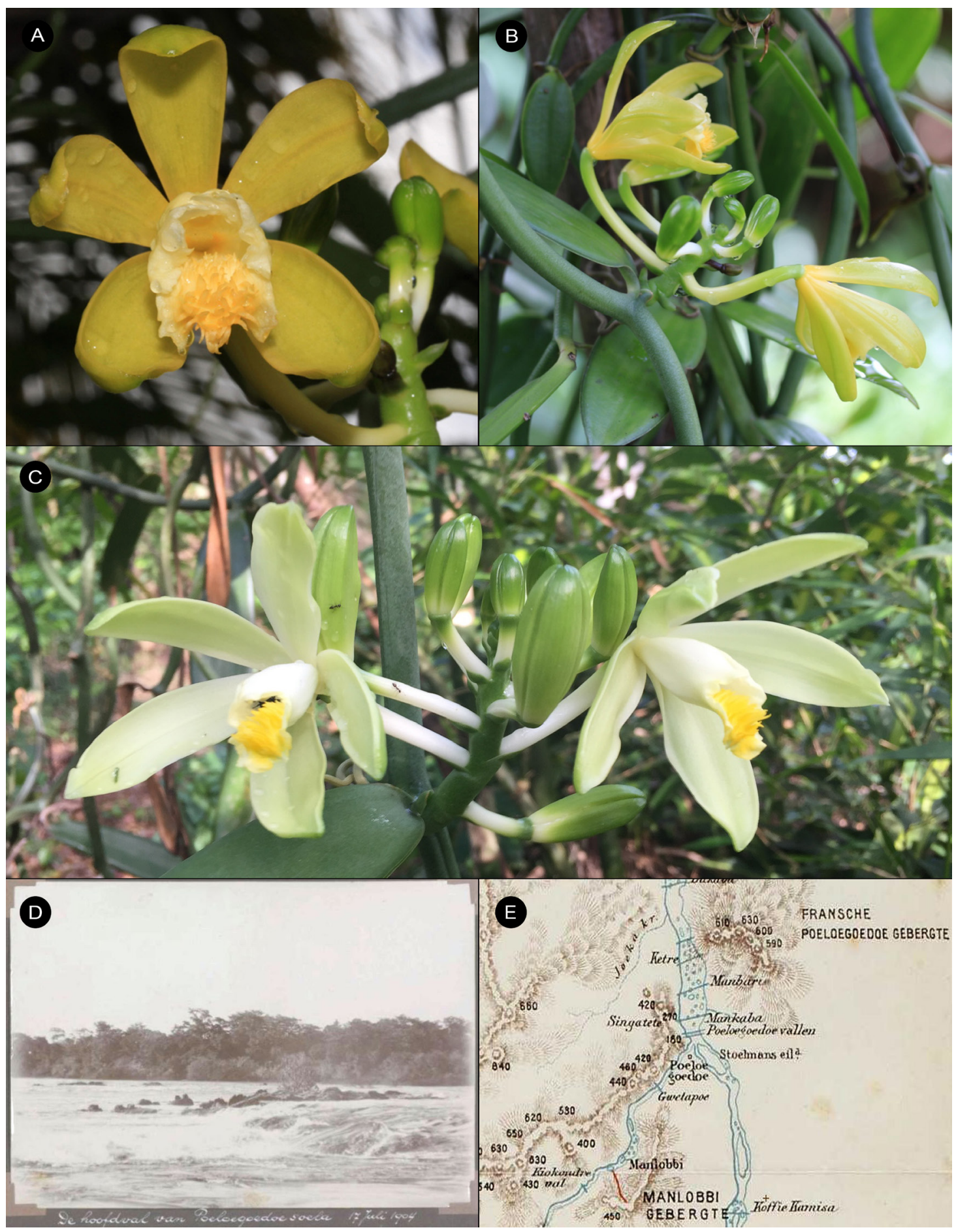

Figure 22. Vanilla marowynensis. A-B. Clonotype of $V$. aspericaulis Sambin \& Chiron cultivated by P. Silland. C. Bolivia, Amboro National Park, in situ, Brylle \& Nathanson s.n. D. Poeloegoedoe on the Marowijne River, type locality of $V$. marowynensis. E. Map of Dutch Tapanahoni expedition to the Marowijne river in the interior of Suriname. 


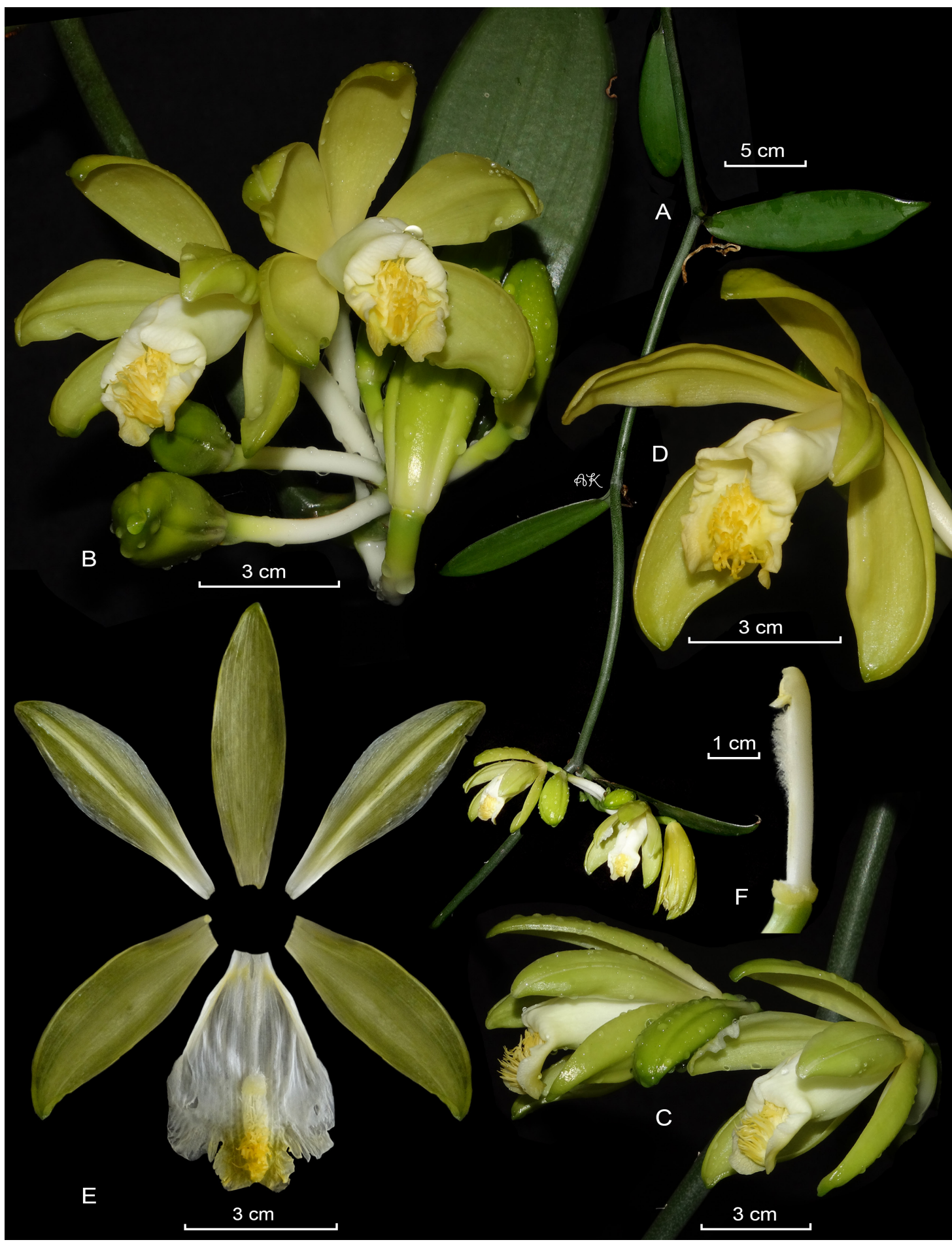

FigURE 23. Lankester Composite Dissection Plate (LCDP) of Vanilla marowynensis Pulle. A. Habit. B. Inflorescence.

C. Inflorescence side view. D. Flower. E. Dissected perianth. F. Column lateral view. By M.E. Engels \& APK based on M.E. Engels 3913 (HERBAM, MBM, TANG). 


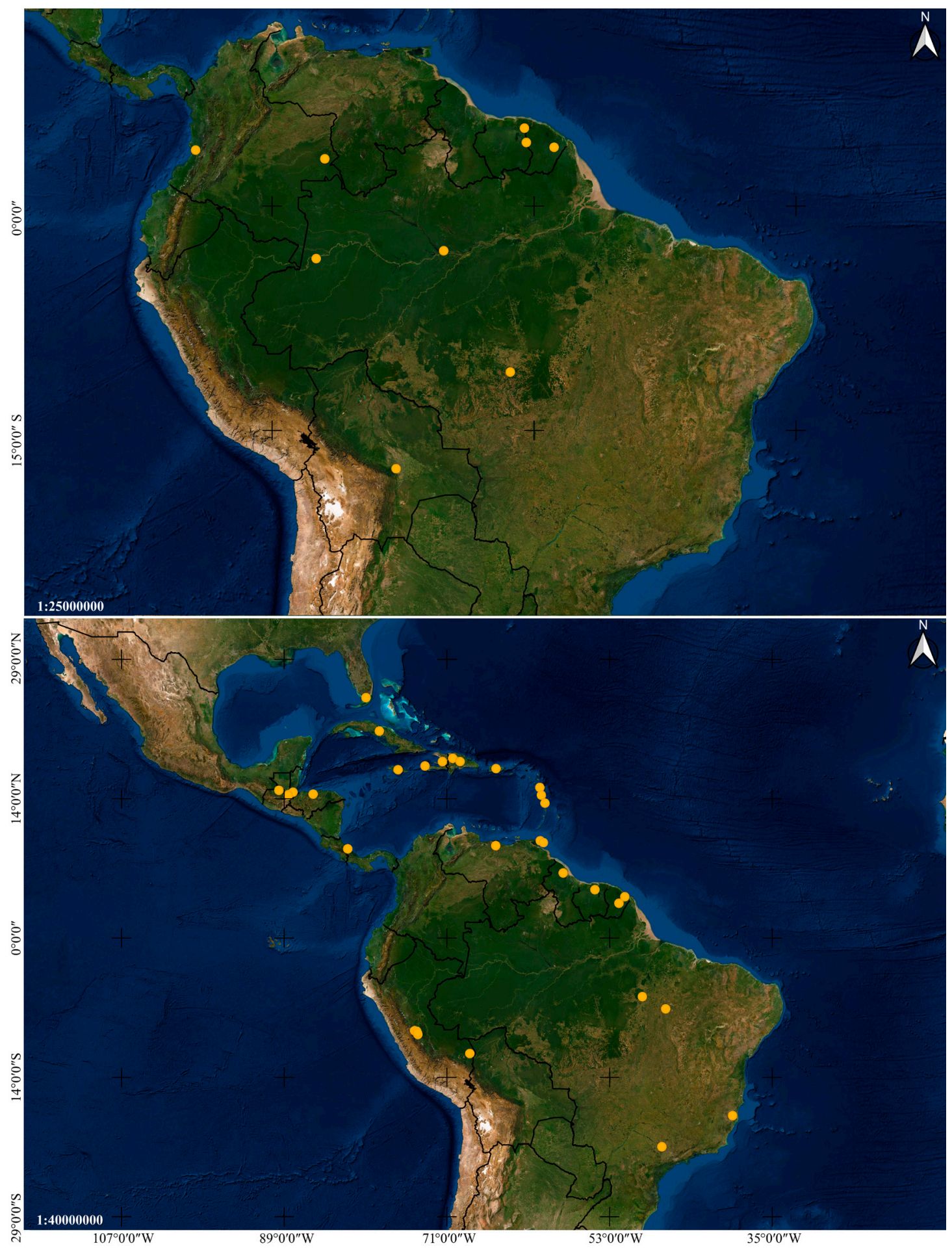

Figure 24. Distribution maps of Vanilla species based on studied specimens. A. Vanilla marowynensis Pulle. B. Vanilla mexicana Mill. Images by IC. 
clearly seen on the dried flowers of the type specimen (Fig. 20). The illustration of $V$. cristato-callosa is virtually identical to the plate based on Engels 3913 (Fig. 23), and although some of the lip features are not easily visible in the type illustration of $V$. marowynensis, they are also quite consistent.

Vanilla aspericaulis described from the French Guiana is said to differ from V. cristagalli in the shorter and broader leaves that are as long as the internodes, the longer ovary, wider sepals, petals and lip and the sub-flabellate lip shape (Sambin \& Chiron 2015). Nevertheless, the original description, illustration and photographs are highly consistent with the type illustration and description of both $V$. marowynensis and V. cristato-callosa. A photo of the clonotype reproduce here (Fig. 22A, B) proves indistinguishable from the materials of those taxa. Similarly, the recently described $V$. denshikoira was said to differ from close relatives mainly in its conspicuously trilobed lip, "external longitudinal canal running from the base to the apex of the reflexed midlobe, and the papillae and elongated trichomes on the ventral lip surface covering the tuberculous keel" (Flanagan et al. 2018). Unfortunately, although the presence of an external longitudinal canal is seldomly noted or illustrated it is a common feature of many Vanilla species, while the remaining characteristics are typical of $V$. marowynensis, and it's synonyms.

Vanilla marowynensis can be recognized by the glaucous, verruculose stems, the internodes similar in length to the coriaceous leaves, which are petiolate, generally broader above the middle and distinctly apiculate. The multi-flowered, successive inflorescence has up to two flowers open at once, it is borne axillarily from a short, thick peduncle, the large, ephemeral flowers, do not open widely, and have thick, greenishcream to yellowish-orange tepals with a white lip bearing dull yellow to orange tuberculate appendages. The lip is three-lobed with the apex of the lobed are conspicuously irregular and incurved, with the margin undulate-crenulate, with a few large teeth, and a dense set of finger-like, tuberculate apical appendages. This distinctive species seems to be rare across its relatively broad distribution, which has prompted its recognition under several names in different countries. Despite not being a narrow endemic this taxon may still be a conservation priority at a local scale as suggested by Flanagan et al. (2018).
6. Vanilla mexicana Mill., Gard. Dict. (ed. 8), no. 1. 1768. Fig. 24B, 25-29.

Replaced synonym: Epidendrum vanilla L., Sp. Pl. ed. 1, 2: 952.1753.

$\equiv$ Vanilla aromatica Sw., Nova Acta Regiae Soc. Sci. Upsal., ser. 2, 6: 66. 1799.

$\equiv$ Epidendrum aromaticum (Sw.) Parm., Cat. Arbr. Parm. 29. 1818.

TYPE: [HAITI]: "Volubilis siliquosa plantaginis folio" in Catesby, Nat. Hist. Carolina 2: app. t. 7.1747 (Fig. $25 \mathrm{~A})$.

Syn.: Vanilla ovata Rolfe, J. Linn. Soc., Bot. 32: 451. 1896, syn. nov.

TYPE: FRENCH GUIANA, J. Martin s.n. (holotype: BM; tracing: K!; isotype: P!; Fig. 26A, 26B)

Syn.: Vanilla martinezii Soto Arenas, Lankesteriana 9(3): 320. 2010, syn. nov.

TYPE: GUATEMALA: Izabal: Mpio. Livingston, El Golfete, a $20.4 \mathrm{~km}$ al NE de Río Dulce por lancha camino a Calix, bejuco herbáceo, flor verde con amarillo y labelo blanco; selva mediana

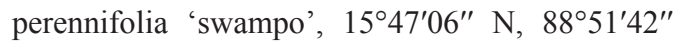
W; E. Martínez S. 36410 y D. Alvarez (holotype: MEXU; isotypes, AMO, BIGUA, MO; illustration of type! Fig. 26C).

Syn.: Vanilla guatemalensis Archila Revista Guatemalensis 2(3): 46. 1999[2012], syn. nov.

TYPE: GUATEMALA. Alta Verapaz: Colectado por Oscar Archila, en pantano de Rubelsanto, cruce para playa grande a $350 \mathrm{~m}$, Junio 1994, FA-sn (holotype: BIGUA; illustration!).

Syn.: Vanilla paludosa Pansarin, J.M.Aguiar \& A.W.C.Ferreira, Brittonia 64(2): 157. 2012, syn. nov.

TYPE: BRAZIL. São Paulo: Msun. Brotas, Fazenda Laranjal, 9 July 2010, E. R. Pansarin, J. M. R. B. V. Aguiar \& A.W.C. Ferreira 1361 (holotype: SPFR; illustration!)

Syn.: Vanilla yanesha Damian, Willdenowia 49(1): 6-8. 2019, syn. nov.

TYPE: PERU. Pasco: Oxapampa, distrito Palcazu, San Francisco de Pichanaz, 10³0'23”S $75^{\circ} 04^{\prime} 19^{\prime \prime} \mathrm{W}, \quad 550 \mathrm{~m}$, bosque secundario, 28 


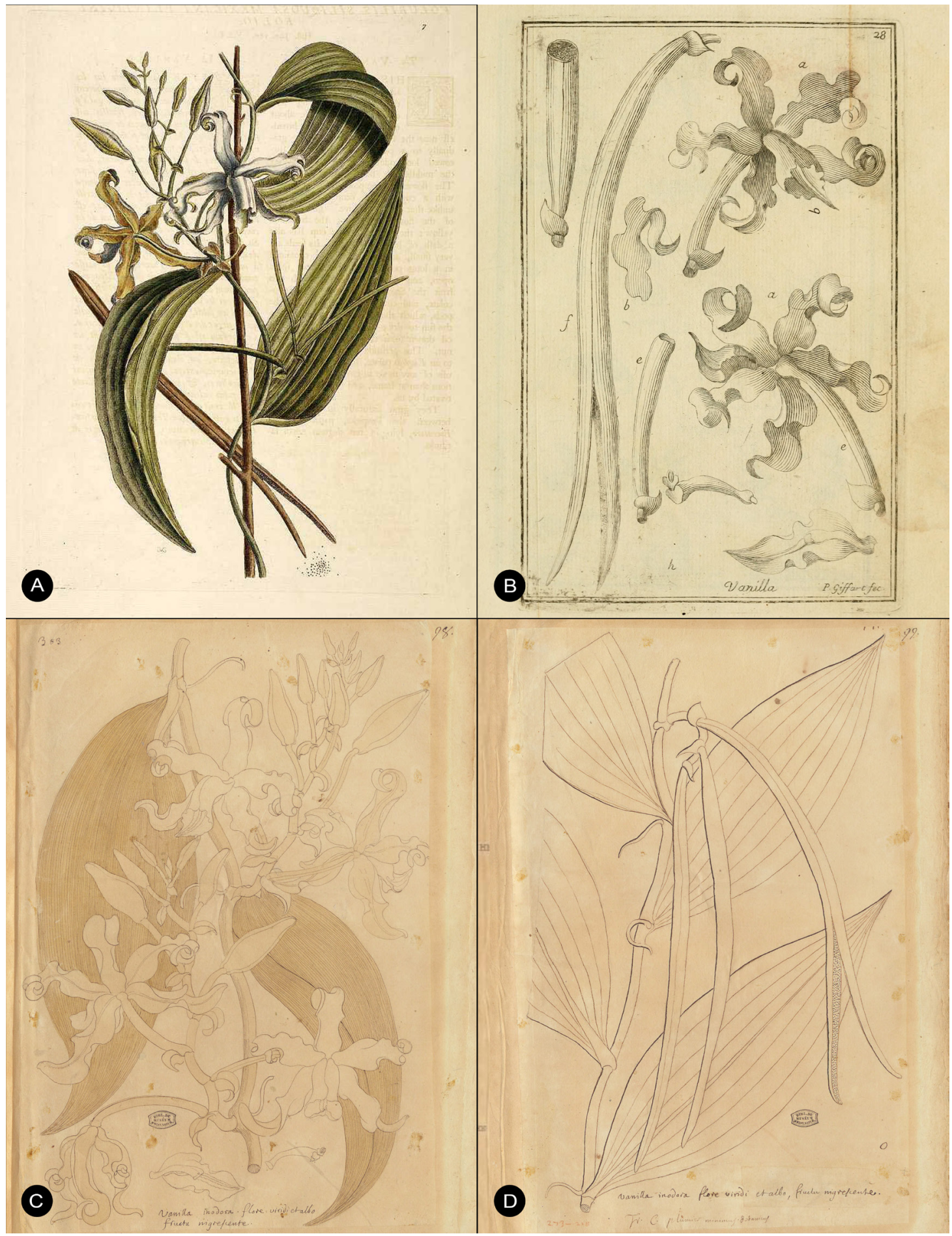

FiguRE 25. Vanilla mexicana Mill. type illustrations. A. "Volubilis siliquosa plantaginis folio" in Catesby, Nat. Hist. Carolina 2: app. t. 7. 1747 (lectotype of V. mexicana). B. Plate 28 in Plumier's Nova plantarum americanarum genera 25. 1703. C-D. Plumier's original illustrations kept at P $\odot$ copyright of the Muséum national d'histoire naturelle, Paris. 
Feb 2006, R. Rojas, J. Mateo \& C. Rojas 3947 (holotype: MO-6049740!, photographs!; isotypes: HOXA-126525!, MO-6049740!, Fig. 27A).

Hemiepiphytic, leafy vine, up to several meters high. Stems branching, terete, fleshy, up to $8 \mathrm{~mm}$ in diameter; internodes 4-9 cm long. Aerial roots, semicylindric, one per internode emerging opposite to the leaf, $15.0-30.0 \times 1.7-2.5 \mathrm{~mm}$. Leaves subsessile; blade broadly elliptic to slight ovate, acute to shortly acuminate, membranaceous to chartaceous, 7.5-30 $\times$ 3.7-12 cm. Inflorescence lateral, axillary, erect, racemose, up to $14 \mathrm{~cm}$ long, with successive flowers, 1-4-opened simultaneously; peduncle abbreviated, rachis terete, internodes up to $5 \mathrm{~cm}$ long, and $5 \mathrm{~mm}$ in diameter; floral bracts small, sessile, ovate, acute, 6-27 $\times 5-20 \mathrm{~mm}$. Ovary (plus pedicel) terete, $4-5 \mathrm{~cm}$ long in open flowers, $3-5 \mathrm{~mm}$ in diameter, arcuate. Flowers with with ovary yellowish-green, lustrous, sepals and petals pale green to yellowish, lip white, yellowish-green to yellowish on the callus, or only above the middle, and column white, with the stigma yellowish to orange; when young, apex of the sepals lightly recurved; petals and sepals more or less flat at anthesis, turning conspicuously reflexed with undulate margins with age, apically deeply recurved, sometimes become uncinate, and lateral sepals dextrorse, rolled outwards. Dorsal sepal elliptic to lanceolate, shortly retuse to obtuse, 11-veined, $3.0-6.5 \times 1.4-1.7 \mathrm{~cm}$. Lateral sepals obliquely elliptic to lanceolate, shortly retuse to obtuse, 11 -veined, $3-6 \times 1.2-2 \mathrm{~cm}$. Petals obliquely elliptic to lanceolate, shortly retuse to obtuse, abaxially sulcate along the midvein, 10 -veined, $3-6 \times 1.0-1.5 \mathrm{~cm}$. Lip fused to the column base along the margins for ca. $8 \mathrm{~mm}$, bell-shape, trilobed; when spread out $2.5-5.0 \times 2.5-4.5 \mathrm{~cm}$; the base obtuse to rounded; the blade cucullate, when spread out widely ovate in outline; the lateral lobes broad rounded, incurved forming a gullet around the column, apically usually overlapping, with raised longitudinal veins forming sulcus; the middle lobe spreading, ovate, acute to obtuse or rounded, porrect, margins flat to undulate, 1-2 $\mathrm{cm}$ wide; the disc with a raised, vertical fleshy callus extending from the base to the apex of the middle lobe, up to $5 \mathrm{~mm}$ wide, formed by 2 vertical keels from the base progressively becoming thicker in the apical $1 / 3$, and a third keel rising in the middle of the disc, the keels sinuous, striate, tapering and rising towards the apex; the distal half of the callus becomes chartaceous, rugulose, and usually with several pseudo-keeled when the flowers are old or dry. Column subterete, slightly sigmoid, arcuate towards the apex, $2.3-3.0 \times 0.3-0.5 \mathrm{~cm}$, wider at the base, with a small keel-like thickening at the base, ventrally canaliculate, apex obtuse, with two lateral short wings. Stigma without lateral lobes. Rostellum oblong and truncate, convex. Anther incumbent, galeate, broadly obovate, $2-4.5 \times 2-4.5 \mathrm{~mm}$. Pollen soft granular not forming a clear pollinarium. Fruit dehiscent, green, dark brown when old, blackish inside, opening by 2 longitudinal valves, non-aromatic, $8.5-15 \times 0.6-1 \mathrm{~cm}$, with ellipsoid black seeds.

Specimens studied: United States. Florida: Cocoplum, Mar. 1960, F.C. Craighead s.n. (FLAS!). Martin Co., Hammock, central Martin county, 29 May 1980, D. Richardson, R.P. Sauleda \& B. Hansen 830 (USF!). Unknown locality, $R$. Coleman s.n. (JBL-photograph!; Fig. 27E). GUATEMALA. Izabal: Creek Lagarto, Ensenada de los Lagartos, El Estor, 2 m, 16 Jul. 1988, E. Martínez 22790, P. Tenorio, H. Droege \& M. Díaz (MEXU, illustration!). Lago Izabal, desembocadura del Río Polochic, Creek Lagarto, al SW de

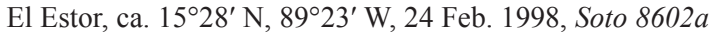
(AMO, illustration!). Cobán: Alta Verapaz, Parque Nacional Laguna Lachua, E.A. Mó s.n. (JBL-photograph!, Fig. 27F). HONDURAS. Atlantida, vicinity of La Ceiba, banks of the Salado river, above the village of Salada, 10 Jul. 1938, T.G. Yunker, J.M. Koepper \& K.A. Wagner 8335 (NY!; AMES!). COSTA RICA. Limón: Talamanca, Cahuita, Parque Nacional Cahuita, Estación de Puerto Vargas, cerca de 300 $\mathrm{m}$ después de la estación hacia Punta Cahuita, $9^{\circ} 44^{\prime} 00.05^{\prime \prime}$ N, 8248'50.01" W, 8 m, 27 Abr. 2012, D. Bogarín 9587, M. Fernández \& F. Pupulin (JBL-spirit!; Fig. 27B). Limón: Talamanca, Cahuita, Parque Nacional Cahuita, Estación de Puerto Vargas, cerca de la estación hacia Punta Cahuita, creciendo a unos pocos metros del mar, 9 $43^{\prime} 53.23^{\prime \prime} \mathrm{N}$, $82^{\circ} 48^{\prime} 53.53^{\prime \prime} \mathrm{W}, 10 \mathrm{~m}, 24 \mathrm{Feb} .2017$, A.P. Karremans 8122 \& I. Chinchilla (JBL-spirit!, Fig. 28, 29). CUBA. Wright 3353 (AMES, K, P-00367030!). JAMAICA. (P-00367031!). 8 May 1903, W. H. Harris 8555 (NY!). Nov. 1885, D. Morris 451 (K!). "Epidendrum 39", De Vriese s.n. (K!). DOMINICAN REPUBLIC. Cordillera Central, Santiago Rodríguez, $2 \mathrm{~km}$. desde la confluencia de los ríos Mao y La Cidra en ruta al Aguacate (de Monción), 12 Jul. 1988, T. Zanoni \& R. García 42003 (NY!). In arboribus scandens ad Jarabacoa, 600 m, 24 May 1887, B. Eggers 2086 (K!). HAITI. 3 milles above Source Chaude on Bras Gauche, Grand Anse River Valley, 12 Jan. 1942, R.J. Seibert 1737 (SEL!). PUERTO RICO. Canovanas: Caribbean National 

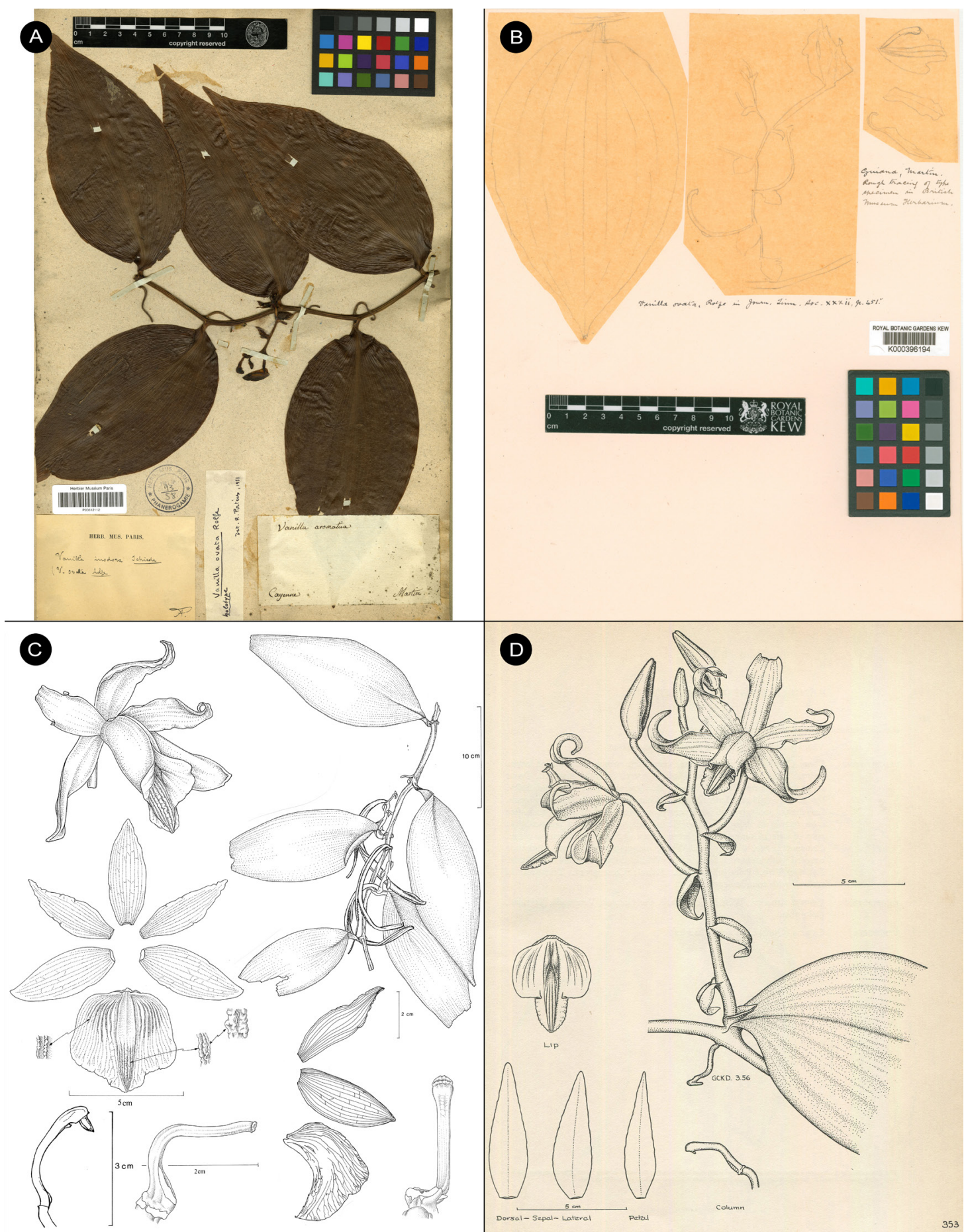

FIGURE 26. Vanilla mexicana specimens and illustrations. A. Isotype of $V$. ovata, Martin s.n. from French Guiana $\odot$ copyright of the Muséum national d'histoire naturelle, Paris. B. Sketches of the type $\mathbb{C}$ copyright of the Board of Trustees of the Royal Botanic Gardens, Kew. C. Type illustration of Vanilla martinezii, Guatemala. D. Illustration by Dunsterville from Venezuela. 
Forest, La Condesa Section, along $2 \mathrm{~km}$ stretch of dirt road off Rt 946, 24 Jan. 1993, F. Axelrod \& Schulz 5639 (NY!). Puerto Rico, Sierra de Luquillo, in monte Jimenes, Jun. 1885, P. Sintenis 1739 (B!; K!). Sierra de Jabucoa, 4 Sep. 1885, Sintenis 2486 (P-00367029!; P-00367028!). Sierra de Luquillo, May 1883, Eggers 1076 (P-00128679!; G 7889/ 178). Sierra de Luquillo, May 1883, B. Eggers 1322 (K!). Prope Yabucoa in sylva primaeva montis Piedra azul, 8 Oct. 1886, P. Sintesis 5469 (K!). GUADELOUPE. Collected between 1882-1900, A. Duss 2081 (NY-32987!). Bois du Bassin Bleu (près du Galion), 1892, P. Duss 238 (P!). Edge of forest, 200 m, 30 Mar. 1956, Smith 10350 (USF!; AMES). Bois Riau, 25 May 1938, A. Questel 2361 bis (P00128682!). Unknown locality, C. \& P. Guezennec s.n. (JBL-photograph!, Fig. 27D). DOMINICA. La Plaine, 18 Jan. 1889, G.A. Ramage s.n. (K!). MARTINIQUE. SainteMarie, Bois La Roche, 16 Apr. 1998, C. Sastra \& G. Pitoulat 9767 (P!). TRINIDAD \& TOBAGO. Arena, less than $50 \mathrm{~m}$, 26 Oct. 1993, P.J.M. Maas, H. Maas \& S. Smith 8147 (U!). Aripo Savanna North, 21 May 1985, J.S. Kenny 29448 (U!). Mora Forest, east of Sangre Grande, 10 Apr. 1921, N.L. Britton \& W. Nowell 2847 (K!). Aripo Savanna, 14 Apr. 1921, N.L. Birtton \& E.G. Britton 2945 (NY!). The Widow near Caledonia, 6 Mar. 1912, W.E. Broadway 3874 (K!). Long Stretch Forest, 18 Mar. 1953, R.E.D. Baker 14732 (K!). M. Crueger s.n. (K!). Arima, 1908, A. Carnegie 1096 (NY04170425!). VENEZUELA. Guatopo, growing profusely at about $1500^{\prime}$ [feet] in rather lighter patch of forest than the average, GCKD. 3.56 (AMES!, illustration; Fig. 26D). French GuIana. Rivière des Cascades. Station des Nouragues, Bassin de l'Approuague, 08 Oct. 2000, Hequet 946 (P-00438751!). Riviere Comté au village Etienne, 19 Dec. 1968, R.A.A. Oldeman B-2080 (P!). La Comté river, P. Silland s.n. (JBL-photograph!, Fig. 27C). SURINAME. Tibiti savanne, along Tibiti R. 17 Jan. 1949, J. Lanjouw \& J.C. Lindeman 1931 (AMES!). PERU. Madre de Dios: Prov. Tambopata, Puerto Maldonado, Carretera Ibera km 18. Aguajal Bello Horizontes, -12.4794 -69.0849, 200-250 m, 20 Jun. 2008, J. Householder, A. Balarezo, J. Huinga 188 (BRIT!). Pasco, Prov. Oxapampa, Dtto. Palcazu. Comunidad Nativa San Francisco de Pichanaz, Bosque secundario, 10³0'48" S, 7504'28" W, 540 m, 27 Jul. 2007, E. Becerra 1611 (USM-252790!, HOXA-041903!, MO632879-photo!, MO-6255510-photo!). Pasco: Oxapampa, distrito Pozuzo, Alto Lagarto a Puente Victoria, $10^{\circ} 06^{\prime} 00^{\prime \prime}$ S, 7526'00" W, 700 m, 28 Dec. 2007, R. Rojas \& G. Ortiz 5146 (USM!, HOXA!, MO-6852664!). BRAZIL. Corcovado: 18 Jan. 1879, A. Glaziou 245 (P-00128684!). Tocantis: Barra do Ouro, Fazenda Santa Rosa, córrego Bacabal, 744'04" S, 4742'17" W, 119 m, 19 Aug. 2010, J.B. Pereira 220 et al. (CEN-00087508!). Espiritu Santo: Linhares, Reserva Natural da CVRD, 29 Mar. 2000, D.A. Folli 3591 (CEN-00060687!). Pará. Rio Itacaiunas, afl. do
Rio Tocantins, serra buritirama (B4), região com minério de manganês, Sept. 1970, J.M. Pires 13072 (IAN-129161!). Amazonas, 20 Mar. 1975, B.G.S. Ribeiro 972 (IAN149662 !).

OTHER SPECIMENS: PUERTO RICO. Kevorkian 6468 (AMES). CUBA. Alain 2295 \& Acuña (AMES); Clemente 2401 (AMES); Britton 5221 \& Wilson (AMES); Schafer 3211 (AMES), 3299 (AMES) \& 7982 (AMES). JAMAICA. Purdie s.n. (K); Wood s.n. (BM, tracing). TRINIDAD \& TOBAGO. Britton s.n. \& Howell (AMES); Freeman s.n. (AMES); Simmonds 334 (AMES); Row \& E.E.C. 11332 (AMES). DOMINCA. Immary 138 (K); W.H. \& B. T. Hodge 3671 (AMES); Ernst 1462 (AMES). Saint Lucia: Proctor 17710 (AMES). HAITI. Eyerdam 395 (AMES) MARTINIQUE. Duss 2081 (AMES).

Distribution: Broadly distributed throughout the Neotropics. Recorded from the U.S.A. (Florida), Guatemala, Honduras, Costa Rica, Cuba, Jamaica, Haiti, Dominican Republic, Puerto Rico, Virgin Islands, Guadeloupe, Grenada, Dominica, Martinique, Saint Lucia, Trinidad \& Tobago, Venezuela, French Guiana, Suriname, Guayana, Peru and Brazil (Fig. 24B).

EXTENT OF OCCURRENCE: $14,481,037.545 \mathrm{~km}^{2}$.

Vanilla mexicana Mill. is the type species of the genus, and the taxonomic history of this species is complex. It has been suggested by some authors (i.e. Soto Arenas \& Dressler 2010), that the name $V$. mexicana is based on Plumier's original illustrations kept at P (Fig. 25C, 25D), on which the Aubriet's and Catesby's (Fig. 25A) are based upon (Reveal 2013), and which was partly reproduced in Plumier's Nova plantarum americanarum genera 25, as plate 28, in 1703 (Fig. 25B). However, Miller (1768) makes reference to a single illustration under the name $V$. mexicana, and it reads "Cat. Car. 3. p. 7." This means that despite being a copy of Plumier, the illustration provided by Catesby is the type of the species. The name Epidendrum vanilla L., published in 1753 , is the first to apply to a species of Vanilla. It has been considered a synonym of $V$. mexicana and as an earlier name would have priority over it. It cannot be used, nevertheless, simply because if combined in genus Vanilla would result in the generic and specific epithets being identical, which is not allowed in plants. When E. vanilla was described, Linnaeus cited six different references without selecting a type. The name was later lectotypified by Cribb (in 


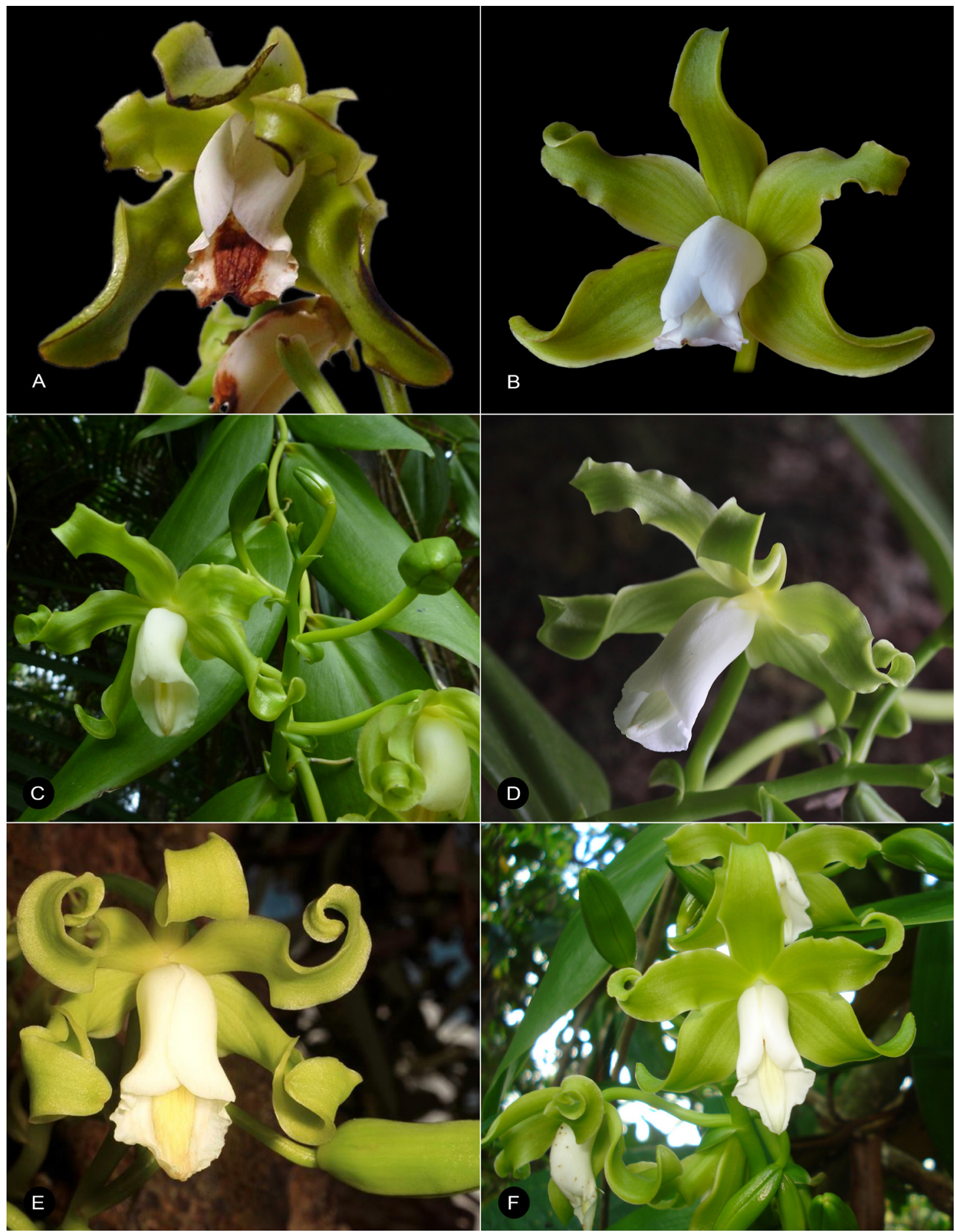

FIgURE 27. Vanilla mexicana flowering specimens from different localities across its distribution. A. Peru, Pasco, from the specimen that served as type of V. yanesha. B. Costa Rica, Cahuita, Bogarín 9587. C. French Guiana, La Comté river, Silland s.n. D. Guadeloupe, C. \& P. Guezennec s.n. E. Florida, photo by Ron Coleman. F. Guatemala, Alta Verapaz, Parque Nacional Laguna Lachua, Mó s.n. Photographs by the collectors. 


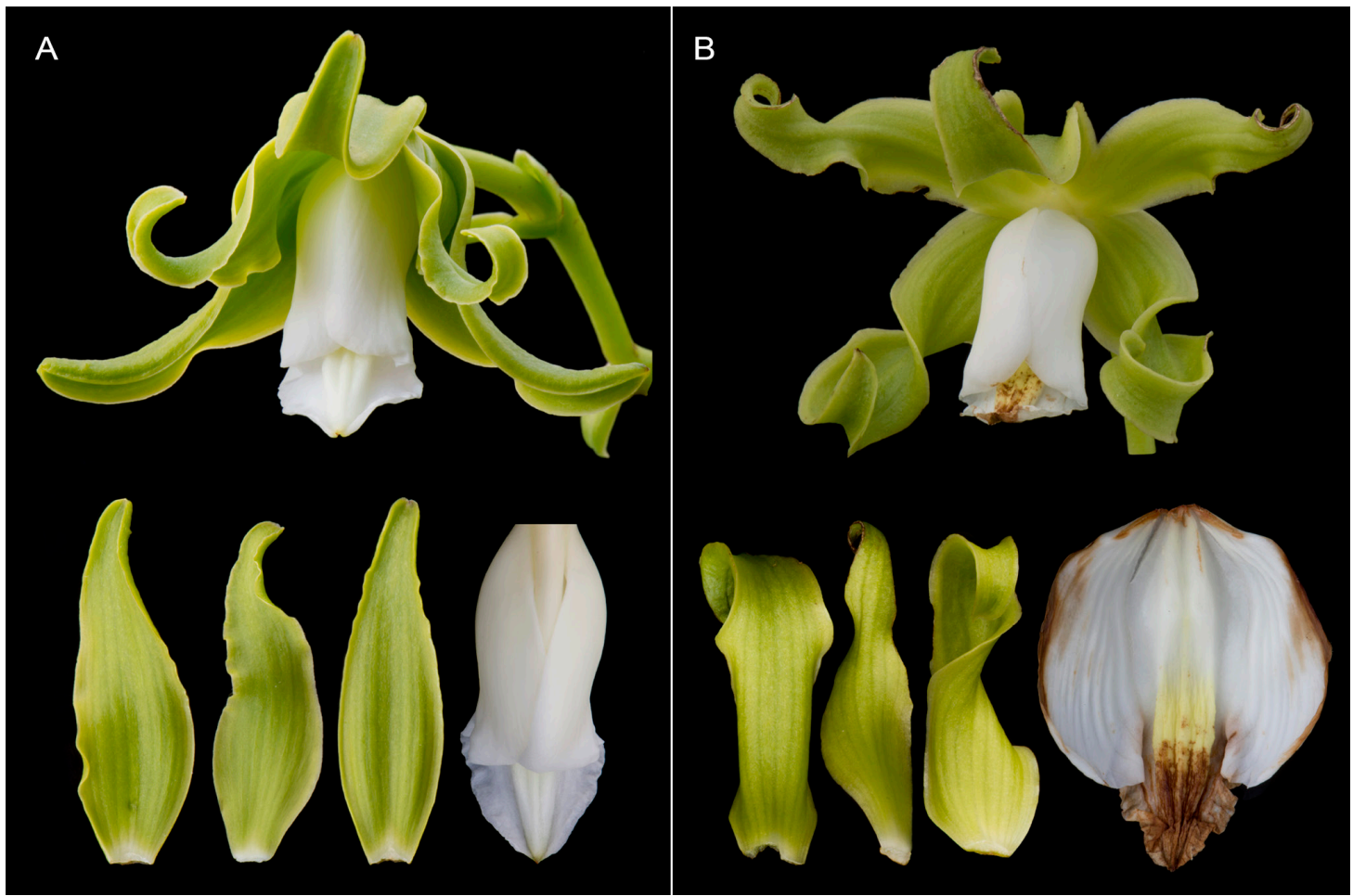

FIGURE 28. Vanilla mexicana showing the morphological transition of flowers within a single inflorescence. A. At anthesis the flower bears almost straight sepals and petals. B. The sepals and petals of a senescent flower that have become fully twisted and undulate. By APK based on Karremans 8122 (JBL-spirit).

Cafferty \& Jarvis 1999), who selected "Catesby, Nat. Hist. Carolina 2: app. t. 7. 1747." Some authors have stated that $V$. mexicana is based on E. vanilla (Garay \& Sweet 1974), while others have pointed out that this is incorrect (Cafferty \& Jarvis 1999). This, however, poses a problem. If the taxa are independent and the types of both $E$. vanilla and $V$. mexicana is Catesby's illustration, then they are not only synonyms but the latter also becomes illegitimate, and a new name needs to be applied to this already quite confused taxon. There is a more harmonious solution. The name $V$. mexicana may simply be considered a nomen novum for E. vanilla, with the citation of Catesby's illustration being an indirect reference as suggested by Art. 41.3 (Turland et al. 2018), which in fact cites other such examples from Miller's work. This would render the name $V$. mexicana legitimate and able to continue in its current usage.

This species is a member of the membranaceous group, which is easily recognized by having membranaceous leaves and the lip without a penicillate callus. This group has species having small scale-like and large leave-like foliaceous floral bracts. Clarifying the type of this taxon is only the tip of the iceberg. Vanilla mexicana is recognized by the broad membranaceous elliptic ovate leaves, a short inflorescence (relative to V. inodora), elongating with time, bearing small floral bracts, long pedicels, pale green to yellowish, twisted, undulate tepals and a white lip, non-unguiculate base, distinctly trilobed, with the lateral lobes rounded, covering the column in natural position, incurved above, and the midlobe rounded to ovate, with a callus formed by two vertical keels from the base progressively becoming thicker in the basal third, and a third keel rising in the middle of the disc extending to the midlobe, the sinuous keels, tapering and rising towards the apex, the callus becoming lower and multi-keeled with age and dehydration. A flower at anthesis (Fig. 28A) and a senescent flower (Fig. 28B) from the same inflorescence show how flowers of $V$. mexicana transition from have almost straight tepals to becoming twisted and undulate, and have a white, three-keeled callus to having a yellowish multi-keeled callus after dehydration. 


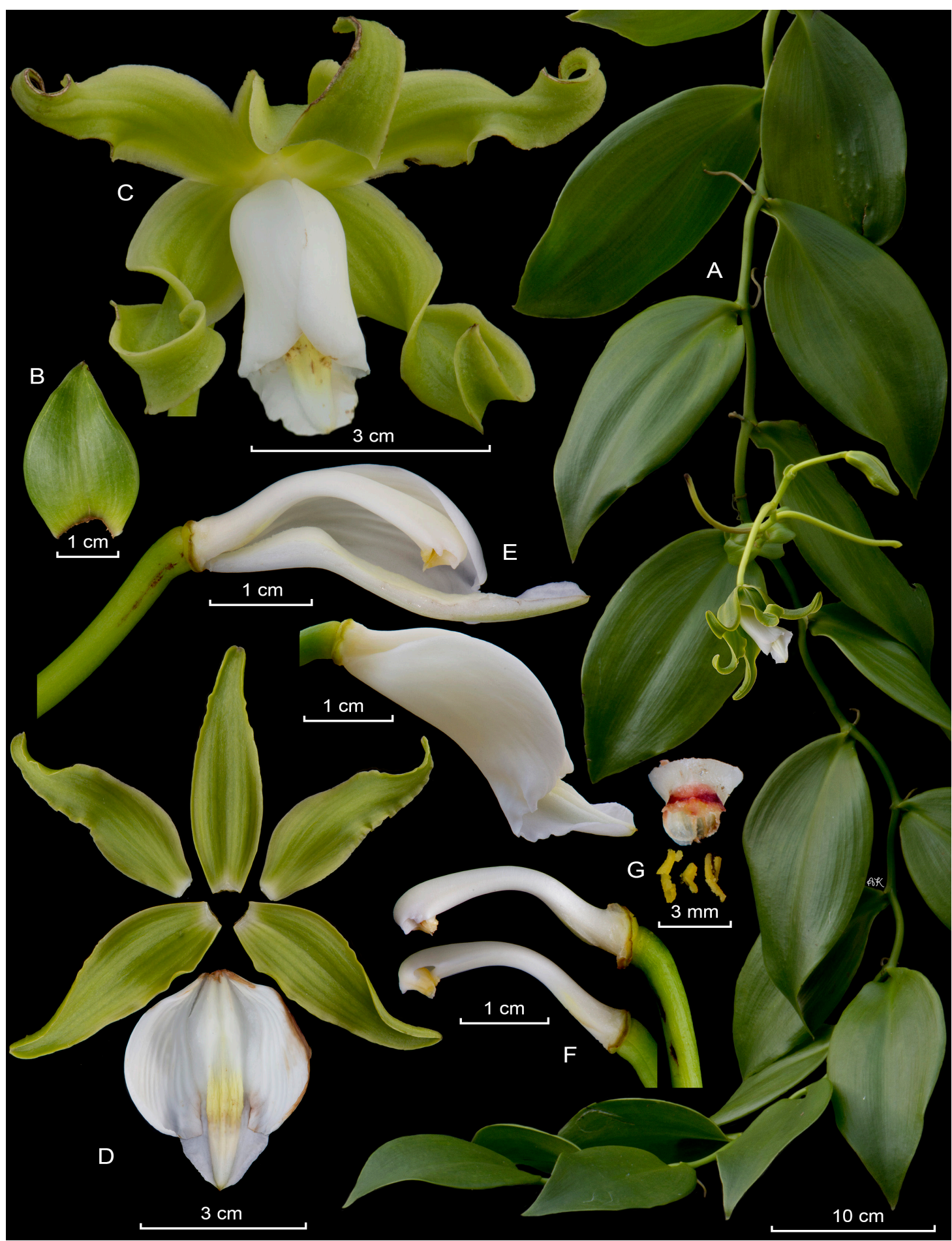

FiguRE 29. LCDP of Vanilla mexicana. A. Habit. B. Inflorescence bract. C. Flower. D. Dissected perianth, flattened. E. Lip and column lateral view. F. Column, side views. G. Anther cap and pollinia. By APK based on Karremans 8122 (JBL-spirit). 
The cryptic name $V$. ovata, based on a plant collected by Martin in French Guiana, is here also placed under $V$. mexicana. The original protologue and sketches (Fig. 26A, 26B) agree with the features of $V$. mexicana, also seen in plants photographed along La Comté river, which is close to the presumed type locality (Fig. 27C). The remaining names discussed here are much more recent. In the past two decades, six species with membranaceous leaves and small floral bracts have been proposed: V. guatemalensis Archila (Archila Morales 2012), V. martinezii Soto Arenas, V. sarapiquensis Soto Arenas (Soto Arenas \& Dressler 2010), V. paludosa Pansarin, J.M.Aguiar \& A.W.C.Ferreira (Pansarin et al. 2012), V. arcuata Pansarin \& M.R.Miranda (Pansarin \& Miranda 2016), and V. yanesha Damian (Damián 2019). Two are clearly distinct. The Costa Rican $V$. sarapiquensis is recognized by its suborbicular, trilobed lip, with a massive callus made up of two elevated, thick, sulcate keels, confluent in the apical part. The Brazilian $V$. arcuata, is recognized by having a column foot, a strongly arched column, with a prominent yellow keel at the base, and a lip with the lateral lobes margin round, recurved and erect forming a gullet only around the distal column section. However, based on the studied of protologues, living and dried herbarium material, illustrations and photos, the other four species are here recognized as conspecific to $V$. mexicana.

Soto Arenas and Dressler (2010) excluded Vanilla mexicana from Central America pointing out that despite the name the species was only known from the West Indies and northeastern South America. Upon proposal, Vanilla guatemalensis wasn't compared with any other species of the genus, and diagnostic characters were not mentioned. Based on the illustration and short description it is inseparable from $V$. mexicana. Also from Guatemala, $V$. martinezii (Fig. 26C) was compared by Soto Arenas and Dressler (2010) to other Central American members of the membranaceous group, $V$. costaricensis Soto Arenas, V. inodora Schiede and $V$. sarapiquensis, and the Amazonian V. guianensis Splitg., but not with $V$. mexicana. The illustration was prepared from a dried specimen and shows more or less straight tepals, the lateral lobes of the lip recurved rather than incurved and the callus multi-keeled, rather than threekeeled. Photographs of living plants from Alta Verapaz, Guatemala (Fig. 27F) show the diagnostic twisted and undulate tepals, the lip forming a gullet around the column, with incurved lateral lobes, and a three-keeled callus on the lip, corresponding well with specimens of V. mexicana from Florida (Fig. 27E) and Guadeloupe in the Antilles (Fig. 27D). The Brazilian V. paludosa, was compared only with the, also Brazilian, $V$. edwallii Hoehne and V. parvifolia Barb.Rodr., both with leaflike floral bracts and easily distinguished by their lip shape. It was not compared with either $V$. mexicana or $V$. martinezii, the two most similar species at the time. The only flower of $V$. paludosa illustrated appears not to have the typical twisted and undulate tepals, however in V. mexicana this feature is age dependent, transitioning from straight at anthesis to highly twisted at senescence (Fig. 28). Otherwise the two taxa are inseparable. The recently published Vanilla yanesha was described from Peru based on dried herbarium specimens belonging to a single collection, as well as photographs of the living plant with senescent flowers (Fig. 27A). It is said to differ from, the sympatric, V. mexicana by having larger leaves, and a lip with more keels. However, examination of multiple specimens of $V$. mexicana shows that leaf size to be variable and that those of $V$. yanesh $a$ are found well within the variation of $V$. mexicana (see Dunsterville \& Garay 1959, p. 432). The callus of $V$. yanesha. is no different from that found in dehydrated specimens of $V$. mexicana, as was suggested for $V$. martinezii. Again here, the taxon is otherwise inseparable from $V$. mexicana.

Vanilla mexicana is a common and widely distributed species from Florida to Peru and Brazil, through Central America and the Caribbean. It is a lowland species and several specimens are annotated as having been collected in coastal mangroves (including the types of $V$. guatemalensis, $V$. martinezii, and $V$. paludosa, and the specimens illustrated from Costa Rica).

7. Vanilla odorata C.Presl, Reliquiae Haenkeanae 1(2): 101. 1827 [1830]. Fig. 30-36, 37A.

TYPE: [ECUADOR:] Hab. in Guayaquil, Haenke s.n. (lectotype designated here: PRC-450948!, two leaves and fruits on the left, Fig. 30; isolectotypes: PR305751!; PR-305752!; PR-305753!, excluding two pseudobulbs of Dimerandra on each side).

Syn.: Vanilla ensifolia Rolfe, Bull. Misc. Inform. Kew, (65/66): 141. 1892. 


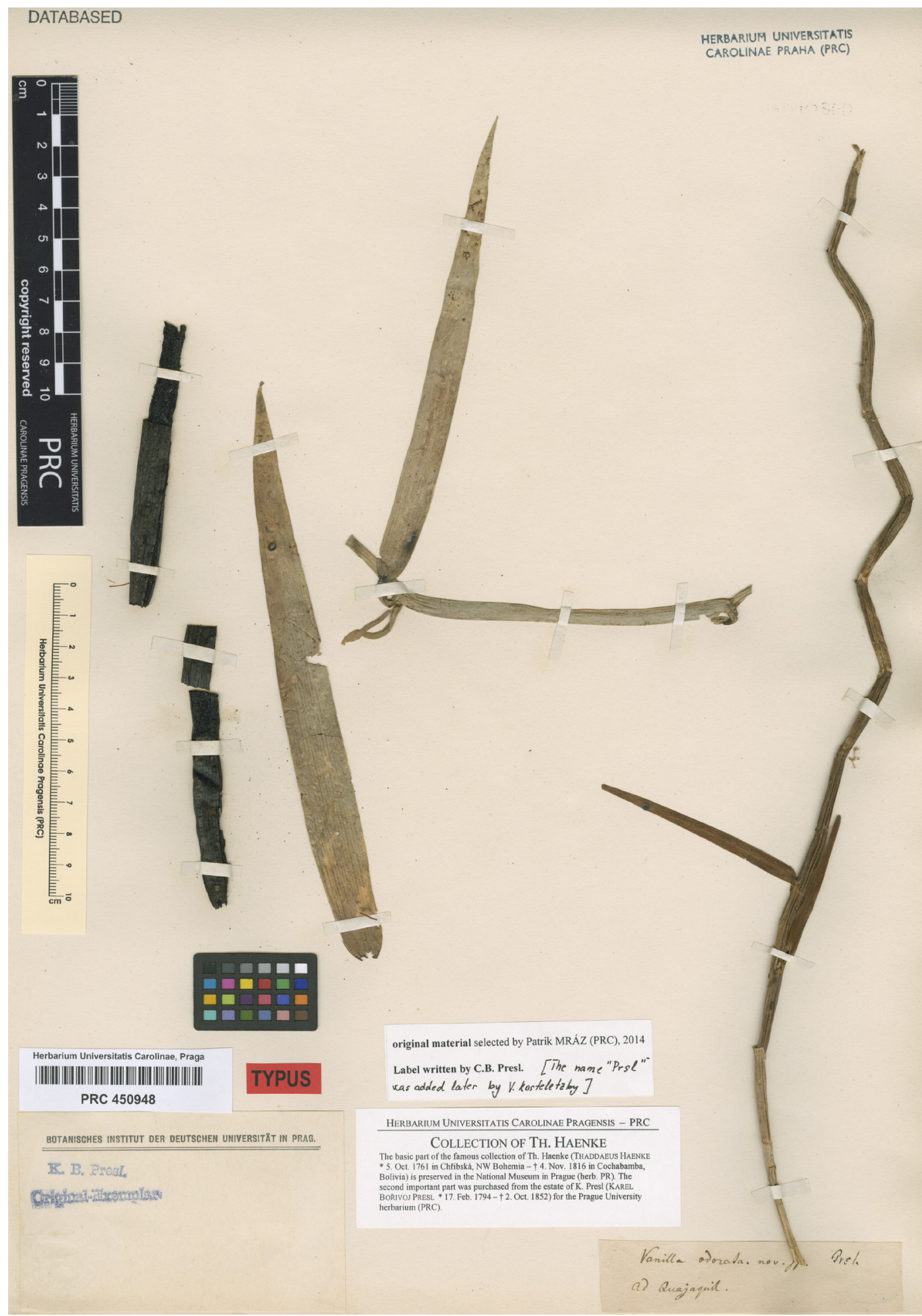

FiguRE 30. Lectotype of Vanilla odorata C.Presl based on Haenke s.n. from Guayaquil (PRC-450948) courtesy of the Charles University in Prague. 


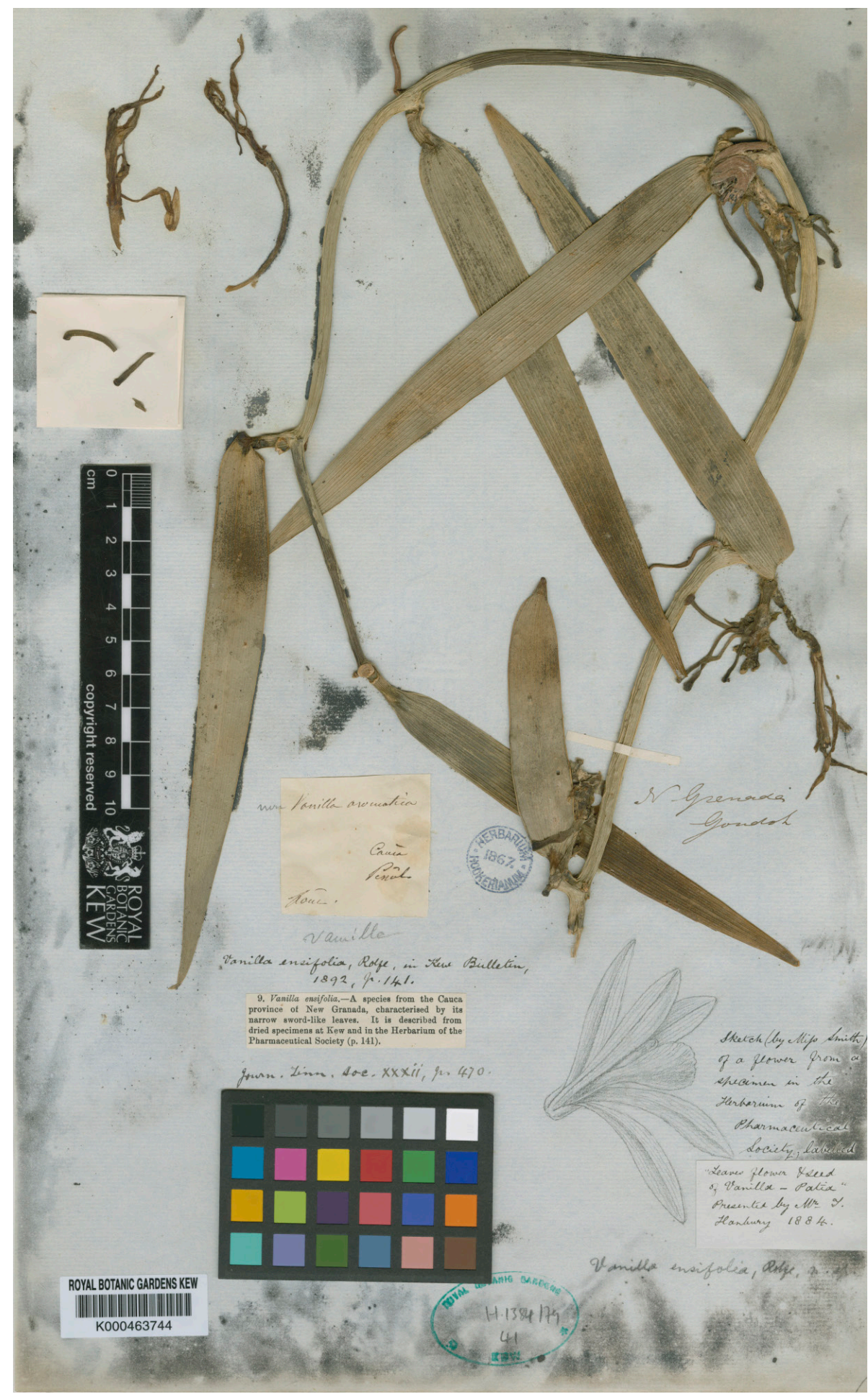

FiguRE 31. Lectotype of Vanilla ensifolia Rolfe based on Hanbury, 1884 from Cauca (K-000463744), (C) copyright of the Board of Trustees of the Royal Botanic Gardens, Kew. 
TYPE: [COLOMBIA:] Cauca, Goudot s.n.; Patia, Her. Pharmaceutical Society, from Mr. T. Hanbury, 1884 (lectotype designated here: K-000463744!, dried specimen, Fig. 31; isolectotype: P-00367037!).

Syn.: Epidendrum vermifugum Sessé \& Moc., Fl. Mex. ed. 2: 201. 1894. Vanilla vermifuga (Sessé \& Moc.) Soto Arenas, nom. nud. in sched.

\section{LECTOTYPE: [MEXICO:] "Epidendrum} vermifugum", Sessé, Mociño, Castillo \& Maldonado 4358 (MA-600496!, Fig. 32A); isolectotypes: "Epidendrum vermifugum de México absque, mounted with "Epidendrum uniflorum" (BM-000923775!; F-848611!).

Syn.: Vanilla denticulata Pabst, Anais Soc. Bot. Brasil, XXIII Congr. Nac. Bot. 109. 1972[1973].

TYPE: BRAZIL: Pernambuco, Engenho Conceição, P. Ferreira 37-67 (holotype: HB-000057667!, Fig. 32B).

Syn.: Vanilla nevermannii Schltr., nom. nud. in sched., syn. nov.

Syn.: Vanilla lancifolia Diar., nom. nud. in sched., syn. nov.

Hemiepiphytic herb, leafy vine, up to several meters high. Stems terete, fleshy, up to $6 \mathrm{~mm}$ in diameter; internodes 6-12 cm long. Aerial roots semicylindric, one per internode emerging laterally to the leaf, 1.5-4.0 $\times 0.2 \mathrm{~cm}$. Leaves subsessile to petiolate, petiole 0.5 $1.0 \mathrm{~cm}$ long; blade lanceolate to narrowly lanceolate, acute to shortly acuminate, coriaceous, $7-23 \times 1-3$ $\mathrm{cm}$. Inflorescence lateral, simple, axillary, racemose, 6-10 successive flowers, 1-2-opened simultaneously; peduncle abbreviated, up to $5 \mathrm{~mm}$ long, rachis terete, up to $4 \mathrm{~cm}$ long. Floral bracts sessile, ovate, acute to obtuse, concave, 5-15 $\times 5-7 \mathrm{~mm}$. Ovary (plus pedicel) terete, lustrous, $2.5-6.0 \mathrm{~cm}$ long in open flowers, 3-4 $\mathrm{mm}$ in diameter, whitish basally. Flowers with the ovary whitish in the basal $1 / 3$, apically dark green, sepals and petals pale whitish-green to yellowish, petals abaxially greenish on the midvein, lip adaxially yellowish, abaxially whitish, column white, whitish to yellowish above the middle, rostellum and anther cap greenish-yellow. Dorsal sepal oblanceolate to elliptic, obtuse to acute, 11-veined, $4.5-6.0 \times 0.8-1.3 \mathrm{~cm}$. Lateral sepals oblanceolate to elliptic, obtuse to acute, $4.5-5.7 \times 0.9-1.5 \mathrm{~cm}, 11$-veined. Petals narrowly oblanceolate to elliptic, obtuse to acute, 4.8-6.0 × 0.9$1.1 \mathrm{~cm}, 9$-veined, abaxially with a vertical keel along the midvein. Lip with the margins fused to the column base for ca. $2.5 \mathrm{~cm}$, tubular, trumpet-shape, shallowly trilobed; when spread 4.1-5.5 $\times 2.2-2.5 \mathrm{~cm}$; the base long unguiculate, the narrow ca. 14-15 × 4-4.5 mm, adaxially lanate in the base; the blade cymbiform, when spread obovate in outline, with warty veins; the lateral lobes rounded, incurved, margins laciniate to fimbriate; the midlobe semi-ovate to semi-quadrate, shortly emarginated, sometimes shortly apiculate in the center, recurved, margins lacerate to laciniate; penicillate callus $2.5-3.5 \mathrm{~cm}$ from the base, ca. 3-4 $\times$ $3 \mathrm{~mm}$; made up by ca. 9 imbricate, flabellate, retrorse, laciniate scales, sometimes united each to other along the lateral margins; continuing for around $20 \mathrm{~mm}$ to the apex, 3-4 mm wide, with 3 keels progressively thickened and confluent towards the apex, forming a fleshy, papillose and warty low cushion, with some prominent conical warts. Column subterete, almost straight, $2.5-3.9 \times 0.25-0.4 \mathrm{~cm}$, from similar width along, ventrally flattened, and lanate, papillose in the apical $1 / 2$, apex with 2 obliquely obtuse, retrorse wings; clinandrium, concave, margins long forming subtriangular to ovate wings. Stigma trilobate, lateral lobes erect, small, $1.5 \times 1 \mathrm{~mm}$. Rostellum subrectangular, convex. Anther versatile, attached to the clinandrium margin, ovoid to quadrate, $3-4 \times$ $3 \mathrm{~mm}$. Pollen not forming a clear pollinarium but a sticky, tow soft, sticky granular mass. Fruit cylindric with attenuate at both ends, aromatic, $15-20 \times 1 \mathrm{~cm}$.

Specimens Studied: MEXICO. Oaxaca: Dto. Tuxtepec, Usila, Arroyo Iguana, vainillal de Silvano Bautista, ca. 250 m, 24 Abr. 1992, M. Soto 6617 \& M. Hernández (AMO; illustration!). Oaxaca: Liebman 294 (W-R-11759!). Quintana Roo: Othón P. Blanco, camino Calderón-Tres Garantías, km 25, 18 $01^{\prime} 15^{\prime \prime} \mathrm{N}, 89^{\circ} 01^{\prime} 00^{\prime \prime} \mathrm{W}, 11$ Abr. 2002, F. May 2167 (CICY!). Quintana Roo: Othón P. Blanco, Paso del Danto, $150 \mathrm{~m}$ al N del rancho de Don Crescencio Cruz, cuenta alrededor de un gran cenote $5 \mathrm{~km}$ al N de La Unión, $17^{\circ} 57^{\prime} 30^{\prime \prime}$ N, 88 $53^{\prime} 06^{\prime \prime}$ W, ca. 0-50 m, 4 Dec. 1997, G. Carnevali, F. May, M. Gómez \& J.C. Chab 4805 (CICY!). Quintana Roo: Othón P. Blanco, Ejido Caobas, Zona general de la Sabana del Jaguactal, un desvío dde $11.5 \mathrm{~km}$ por carretera de terracería al este de la carretera Crucero Nuevo Becal-Tres Garantía, unos $22 \mathrm{~km}$ al sure en línea recta desde la carretera Xpujil-Chetumal, apox, $18^{\circ} 15^{\prime} 34.10^{\prime \prime} \mathrm{N}$, $88^{\circ} 56^{\prime} 39.60^{\prime \prime}$ W, ca. $141 \mathrm{~m}, 8$ Dec. 2016, G. Carnevali, et al. 7991 (CICY!). BELIZE. Trail through light jungle, near 


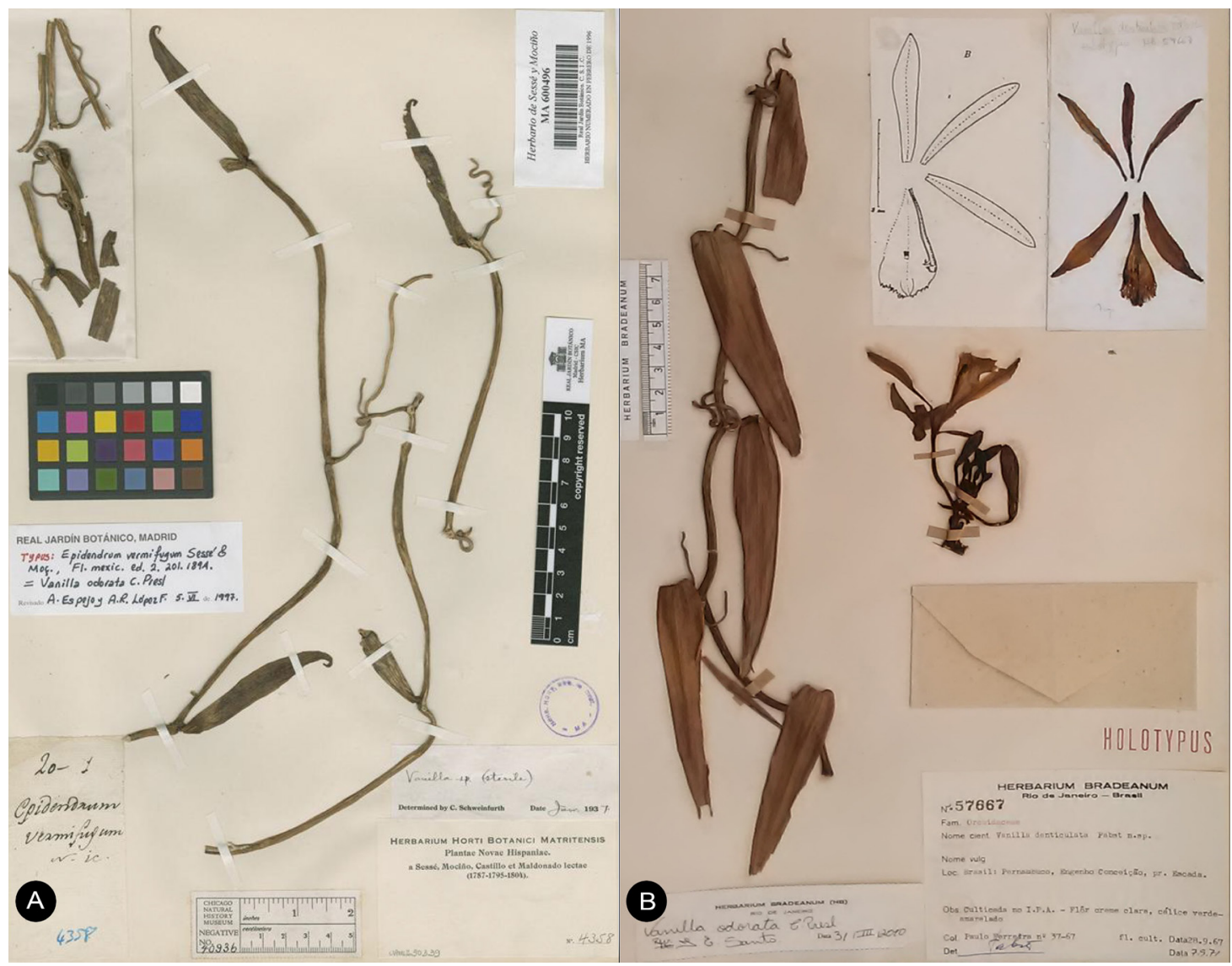

FiguRE 32. Vanilla odorata. A. Lectotype of Epidendrum vermifugum Sessé \& Moc., Sessé, Mociño, Castillo \& Maldonado 4358 (MA-600496), (C) copyright of the Real Jardín Botánico, Madrid. B. Holotype of Vanilla denticulata Pabst, $P$. Ferreira 37-67 (HB-000057667), courtesy of Herbarium Bradeanum.

camp. 2, elev. 2000 ft., 20 Aug.1976, C. Whitefoord 1316 (MO-2584013!). Toledo: Sarstoon Temash National Park, Sarstoon River, 15 m, 15.89528333333333, -89.02, 3 Dec. 2014, B.K. Holst et al. 10000 (SEL-photo!). GUATEMALA. Alta Vera Paz: Mar. 1881, Türckheim 586 (W-R-12951!). Peten: Libertad and vecinity, Aug-Nov. 1933, H. Mercedes Aguilar 164 (AMES-40519!; AMO-photo!). Tikal, in botonal north of hotel, 20 Jan 1961, E. Contreras 1841 (LL!). HONDURAS. Lancetilla, 150 ft., T.G. Yuncker 4993 (NY00984265!). Colón: $1.8 \mathrm{~min}$. Strip on the north bank of rio Guaimoreto between old bridge and opening of Laguna Guaimoreto $4.5 \mathrm{~min}$. NE of Trujillo on old roal to Castilla, $15^{\circ} 57^{\prime} 30^{\prime \prime}$ N, 8554'30" W, 2 Feb. 1981, J. Saunders 1008 (SEL!, TEX!; AMO-photo!). Atlantida: Campamento Quebrada Grande, $10 \mathrm{~km} \mathrm{SW}$ of La Ceiba, $15^{\circ} 42^{\prime} \mathrm{N}, 86^{\circ} 51^{\prime}$ W, 80-200 m, 15 May 1993, R.L. Liesner \& D. Mejia 26360(MO-04649983!). NICARAGUA. Segovia: E of Jalapa, elev. 1600 ft., May-Jun., A.H. Heller 6106 [SEL013289!; SEL-003851!; F-003851; AMO-photo!; illustration in Hamer (1984)!]. COSTA RICA. Alajuela. Los Chiles, Los Chiles, camino a Bandera, al lado del camino, 10 $53^{\prime} 25.35^{\prime \prime}$ N, 84²30'03.96" W, 66 m, 30 Set. 2017, A. Karremans 8101, I. Chinchilla \& M. Cedeño (JBL-spirit!, Fig. 33). Limón: Hamburg Finca, on the Río Reventazón below Cairo, 55 m, 19. Feb. 1926, P.C. Standley \& J. Valerio 48917 (AMES32665!; US-1309433!; AMO-photo!). Golfito, Jiménez, camino a Agua Buena. Estación Biológica Piro, 8²4'03.83" N, 8320'09.51" W, 24 m, 28 Oct. 2014, A. Karremans 6440, J. Geml, M. Lopez, J. Murillo, L. Parra, Carlos Rojo, Marisa Vázquez (JBL-spirit!, Fig. 34). COLOMBIA. Antioquia: Carretera Mutatá-Pavarandó, entre hacienda La Esperanza y Mocarí, 150 m, 6 Mar. 1987, R. Fonnegra, F.J. Roldán, J. Betancourt, B. Echeverry, O. Escobar 1784 (MO-3592235!1 AMO-photo!). Valle: Zarazal, Hacienda El Medio, carretera Panamericana entre La Paila y Zarazal, valle del Río Cauca, 950 m, (hay fotos), 16 Abr. 1987, F.A. Silverstone-Sopkin 3105 (MO-05015894!). Santa Marta, Wallis 4.68 (W-R21188!). Cauca, Goudot s.n. (W-R-21426!). Medellín, Wallis 
s.n. (W-R-21454!). Llano de San Martín, Villavicencio, 100 m, Jan. 1856, J.J. Triana 1614/2 (COL-000363315!; P-00367024!; W-19373!). 20 Mar. 1858, A.C.V. Schott 12 (F!; NY!). VENEZUELA. Territorio Federal Amazonas, Atabapo, forest slope of Marahuaca, 1 to $2 \mathrm{~km}$ north of Sima Camp, 343' N, 65³1' W, 1100 m, 8-9 Mar. 1985, R.L. Liesner 18444 (NY!). Bolívar, Falcón, La Tabla, Sierra de San Luis, M. Speckmaier s.n. (JBL-photo!, Fig. 35A). ECUADOR. Napo: Collected near Tena, oritente del norte, $2000 \mathrm{ft}$., AprMay 1923, F. Williams s.n. (AMES-26313!). Hacienda la Virginia, Wallis 181 (W-R-21194!). Without locality, $30 \mathrm{Apr}$. 1897, Eggers 15138 (F-143393!). FRENCH GUIANA. Route Régina-Saint Georges, Bassin de L'Approuague, $4^{\circ} 2^{\prime}$ N, 52॰1' W, 100 m, G. Cremers \& J.J. De Granville 14281 (P-00367047!). Saint Georges, RN 2, à $100 \mathrm{~m}$ de la savane 14 Juillet, 09 Nov. 1998, O. Poncy, F. Crozier \& P. Grenand 1141 (P-00166858!). Crique tigre. Bassin du Sinnamary, 23 Nov. 1993, B. Bordenave 512 (P-00224525!). G. Leotard s.n. (JBL-photo!, Fig. 35B). SURINAME. Bakhuis, concession BMS: Zone 21, 4²3'57" N, 5704'49" W, 200 m, 15 Apr. 2006, B.G. Bordenave 8517, F. Van Troon, I. Van Troon \& J. James (MO-04799286!). PERU. On the Amazon River, Sep. 1929, L. Williams 3161 (AMES-43483!; AMO-photo!). Amazonas: Prov. Bagua, Chiriaco, al borde de tributario del rio Chiriaco cerca a la Comunidad Nativa Pakuy, propiedad de Damián Shakai, 24 Abr. 2016, 302 m, A. Damián, L. Rimarachin, D. Shakai, A. Uwek ADP008-1 (MOL!, Fig. 36), ibid. ADP008-2 (MOL!); Prov. Bagua, Dist. Bagua, Centro poblado Naranjos, 23 Abr. 2016, 767 m, A. Damián, L. Rimarachin, G. Becerra, M. Villalobos ADP002-39 (MOL!); Prov. Bagua, Yamayakat, Trocha Putuim bosque primario, 500 m, 17 Oct. 1996, R. Vásquez, N. Jaramillo 20316 (SEL!, MO-05097620!). Loreto: Lower Rio Huallaga, Yurimaguas, 133 m, 23 Aug. 7 Sep. 1929, E.P. Killip 29065 \& A.C. Smith (AMES!; NY!; AMO-photo!). Lower Rio Huallaga, Yurimaguas, 155-210 m, 4 Nov. 1929, L. Williams 4539 (F618740!). Lower Rio Huallaga, Río Mayo, 360-900 m, 14 Dec. 1929, L. Williams 6272 (F-621011!). Prov. Maynas, Caserio Mishana, forest on white sand soil, 1-2 hr. walk from river, vine, 4-6 Sep. 1974, R.B. \& W.A. Foster 4090 (USM 45900!, F 1893719!); Prov. Maynas, Dtto. Las Amazonas, Yanayacu, 808788962123596 m, Aug. 2016, A. Damián, N. Mitidieri ADP4016-1 (MOL!); Prov. Maynas, Dtto. Belén, 2 de mayo de Muyuy, 6924919572309108 m, Aug. 2016, A. Damián, N. Mitidieri 4001 (MOL!); Prov. Maynas, Dtto. Iquitos, Quistococha, 6870829576191103 m, Aug. 2016, A. Damián, N. Mitidieri 4026 (MOL!); Prov. Maynas, Rio Yubineto, 72.20 W 1 S, 150 m, Jan. 1978, S. Barrier 272 (MO-4315231!). Ucayali: Prov. Coronel Portillo, Leoncio Prado, Yarinacocha, 08 $20^{\circ} \mathrm{S} 074^{\circ} 35^{\prime} \mathrm{W}, 200$ m, 15 May 1984, R. Vásquez 4995 (MO-3303424!, NY-04170436!); Prov. Coronel Portillo, Dtto. Iparia Reserva Comunal el Sira (zona de amortiguamiento), -9.13076, -74.4984, 172 m., 30
Nov. 2015, J. Janovec, J. Ushiñawa, H. Behar 4002, 4004 (MOL!). Cajamarca: San Ignacio, Dtto. Namballe, bosque el pacashal, bosque primario, margen derecho del rio Canchis, 0501 ' S 79 01' W, 650-800 m, 10 Jul. 1997, E. Rodríguez \& O. Pesantes 1656 (HUT!, MO!, USM!); Dtto. Namballe, de la colmena a morero, vegetación secundaria. 05 00’30" S 79 04' 00”, 1000-1150 m, 12 Jan. 1997, J. Campos, G. Pezantes 3305 (MO-5579312!, SEL!, USM!); Prov. San Ignacio, Nuevo Perú, 900 m, 14 May 1996, R. Vásquez, A. Vásquez 20842 (SEL!, MO-05098926!). CUSCO, Prov. La Convención, en Serjali, Rio Mishagua, 11¹'58.18'S 7258'26.31'O, G. Shepard, R. Foster 730 (USM!). San Martin: Prov. Mariscal Cáceres, Dtto. Tocache Nuevo, 08¹1'03'S 076³0'45"W, 400-700 m, J. Schunke 11060 (MO-5569374!, SEL!); Prov. Moyobamba, Dtto. Moyobamba, Reserva Ecológica de Tingana, 553'52”S, 7707'12”W, 26 Jan. 2019, D. Cabrera \& M. Leon s.n. (MOL!); prov. San Martin, Dtto. Tarapoto, Instituto de Investigación Biológica de las Cordilleras Orientales (INIBICO), 351873.26 m E 9283680.67 m S 500 m, Jun. 2019, A Damián \& M. Leon s.n. (USM!). Madre de Dios: Parque Nacional Bahuaja Sonene, Rio Heath, 527882 8601719, 24 Jun. 1999, P. Núñez, A. Monteagudo 26245 (CUZ!); Prov. Manu, Manu Park, Cocha Cashu uplands, Collpa Guacamayo vicinity, $11^{\circ} 45^{\prime} \mathrm{S} 071^{\circ} 10^{\prime} \mathrm{W}, 400 \mathrm{~m}, 7$ Sep. 1986, P. Núñez 6015 (MO-3430874!); Puerto Maldonado, Rio Alto Madre de Dios-Boca Manu, -12.2566, -70.898, 280-320 m, 21 Aug. 2009, probablemente J. Householder et al. 940 (USM!). BOLIVIA. Beni: Rurrenabaque, elev. 900-1000 ft., 3 Dec. 1921, O.E. White 1821 (AMES-28026!, NY-04170434!; AMO-photo!). La Paz: Ixiamas, 13 Dec. 1921, 1000-1500 ft., O.E. White 1115 (AMES-28024!; AMO-photo!). Guarayos. Reserva de vida silvestre ríos Blanco y Negro. Campamento sobre Río Negro de Caimanes, unos $4 \mathrm{~km}$ al SE de las Juntas con el Río San

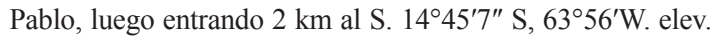
ca. 250 m, 18 Jun. 1993, I. G. Vargas, J. Balcazar \& N. Tagua 2617 (F-2295772!). Dept. Beni, Prov. of Vaca Diez, vicinity of the Chácobo village Alto Ivon, $11^{\circ} 45^{\prime} \mathrm{S}, 66^{\circ} 02^{\prime} \mathrm{W}$, ca. 200 m, 31 Mar. 1984, B.M. Boom 4893 (NY!). BRAZIL. Pará:

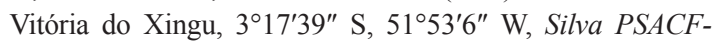
EX05383 (RB-01031586!). Tucuruí, $12 \mathrm{~km} \mathrm{~N}$ of town of Tucuruí along road to Cametá, aprox. $3^{\circ} 36^{\prime} \mathrm{S}, 49^{\circ} 44^{\prime} \mathrm{W}, 50$ m, 21 Mar. 1980, T. Plowman 9868 \& N.A. Rosa, C.S. Rosario (NY-02695612!). Amapá: cultivated in the orquidario of IAN, J.S. Rodrigues 218 (IAN-102239!). Mato Grosso, 18911892, S.L.M. Moore 657 a (NY-00910932!).

OTHER SPECIMENS: Without locality, "Vanilla lancifolia Diar.”, Feb 1833, Poeppig s.n (W-R-19352!). Without locality, Splitgerber 1174 (W-R-19375!). NICARAGUA. Zelaya: [sterile]" Vainilla", bejuco, sobre árboles, Guamil de segunda clase. Area de Ocotal, Río Grande, Alt. 0-15 m, Abril 23, 1949, A. Molina 2312 (F-1364505). 


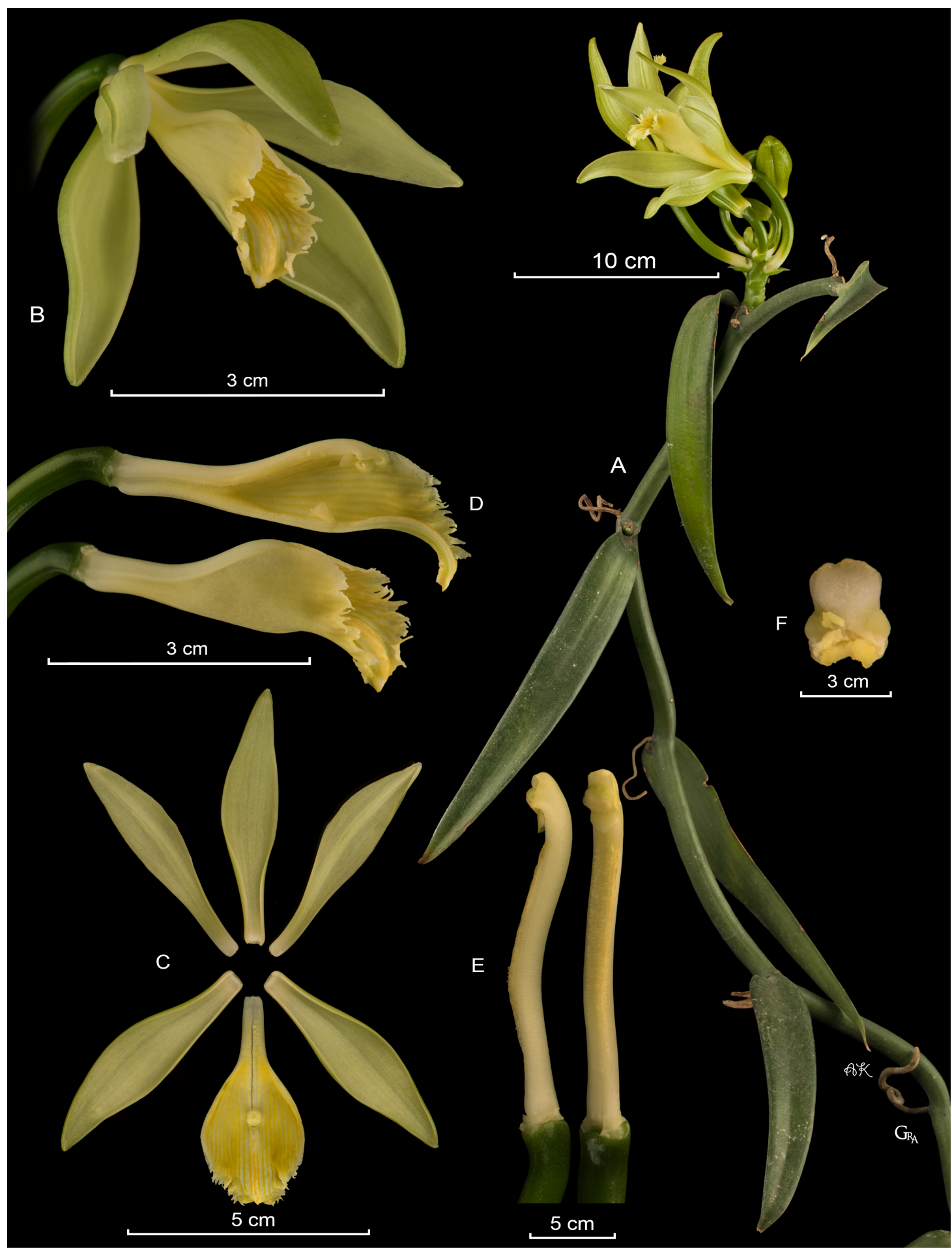

Figure 33. LCDP of Vanilla odorata. A. Habit. B. Flower. C. Dissected perianth, flattened. D. Lip and column lateral view. E. Column, side and ventral views. G. Anther cap and pollinia. By APK and GRA based on Karremans 8101 (JBL- 


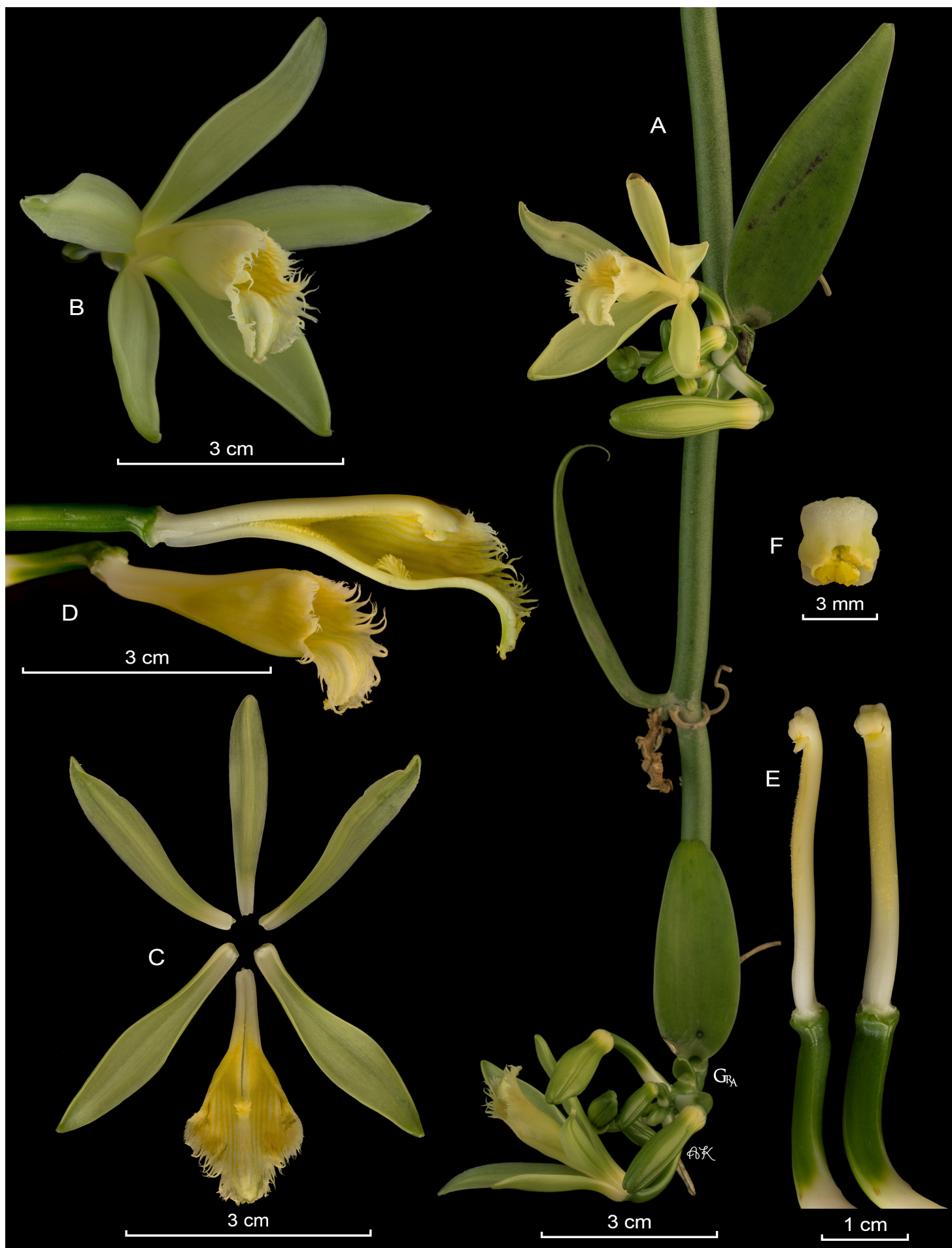

FiguRe 34. LCDP of Vanilla odorata. A. Habit. B. Flower. C. Dissected perianth, flattened. D. Lip and column lateral view. E. Column, side and ventral views. G. Anther cap and pollinia. By APK and GRA based on Karremans 6440 (JBL-spirit). 


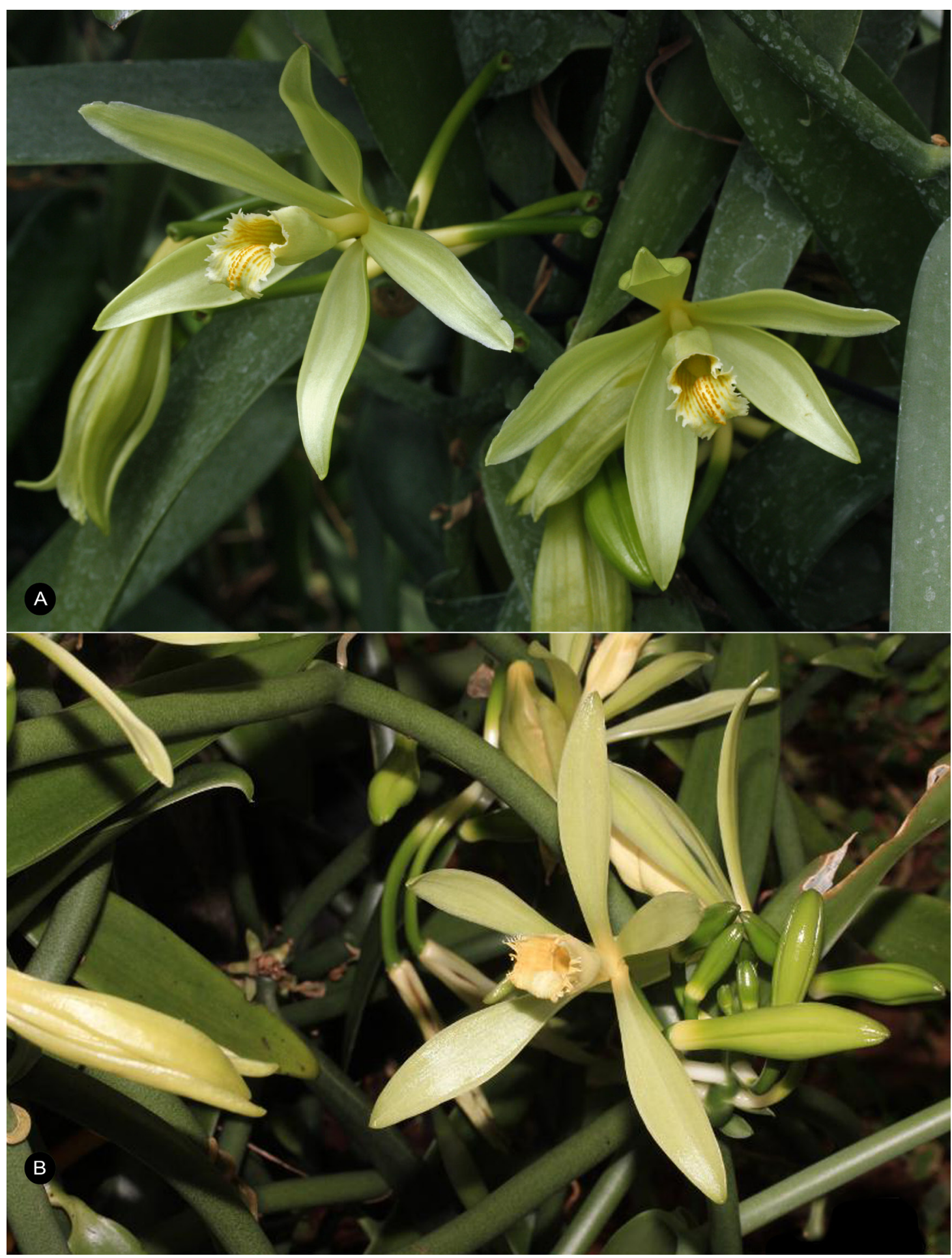

Figure 35. Vanilla odorata. A. Venezuela, M. Speckmaier s.n. B. French Guiana, L. Leotard s.n. Photographs by the collectors kept at JBL. 


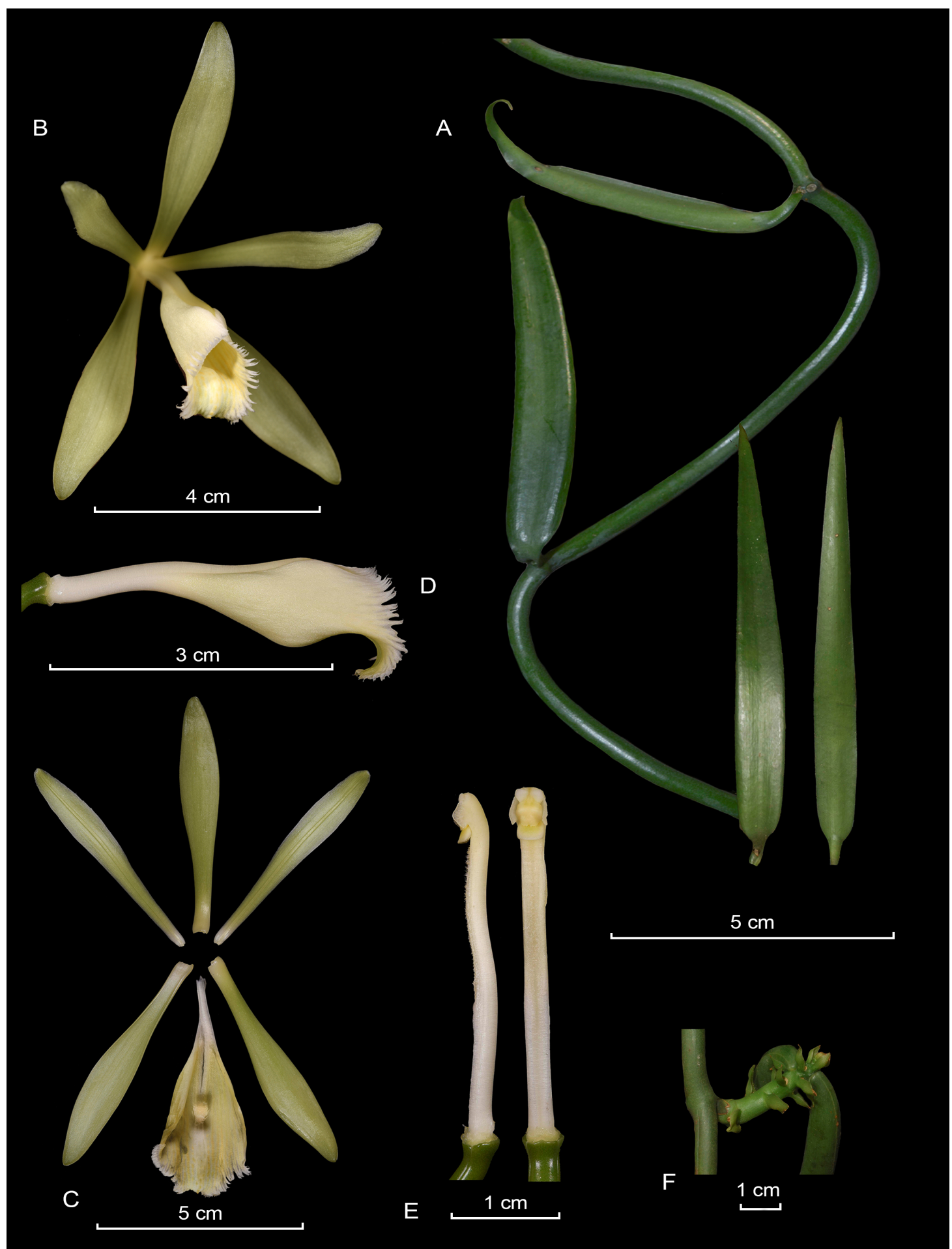

Figure 36. LCDP of Vanilla odorata. A. Habit. B. Flower. C. Dissected perianth, flattened. D. Lip and column lateral view. E. Column, side and ventral views. G. Anther cap and pollinia. By AD based on ADP008-1 (MOL). 


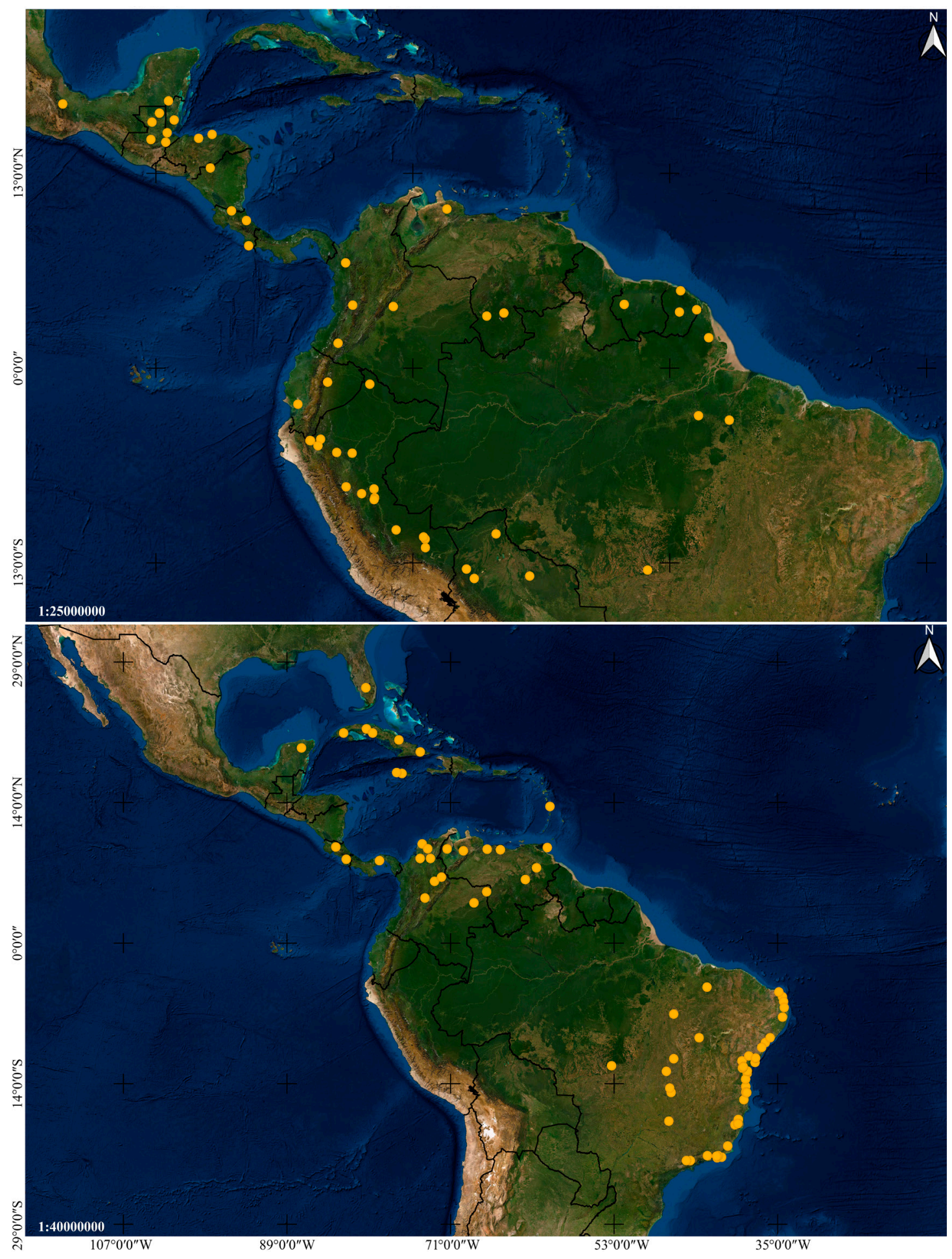

Figure 37. Distribution maps of Vanilla species based on studied specimens. A. Vanilla odorata C.Presl. B. Vanilla phaeantha Rchb.f. Images by IC. 
Distribution: Broadly distributed in the Neotropics, reported from Mexico, Guatemala, Belize, Honduras, Nicaragua, Costa Rica, Panama, Colombia, Ecuador, Peru, Bolivia and Brazil (Fig. 37A).

EXTENT OF OCCURRENCE: 9,800,665.659 km².

Vanilla odorata is characterized by its narrowly lanceolate, acute to shortly acuminate leaves (Fig. 30, $31,32 \mathrm{~A}, 33,35)$, although shorter, broader leaves are present in some populations (Figs. 32B, 34). The pale green to yellowish sepals and petals, yellowish-white lip with the throat stripped with yellow and lacerate to fimbriate margins, are diagnostic of the species. Vanilla odorata is similar to Vanilla insignis Ames, but, the latter has thicker, sulcate, rugose to papillose stems, broader, xeromorphic oblong leaves, and the retrorse appendages of the lip apex are much more numerous, bigger and orange-yellow, both species share a lacerate to fimbriate lip margin. Flowers of $V$. odorata are also similar to $V$. planifolia Andrews, but the latter has an undulate, crenate, dentate or serrate lip margin ( $v s$. lacerate to fimbriate). The lanceolate to narrowly lanceolate leaves of $V$. odorata set the two apart easily. Plants of $V$. karen-chistianae Karremans \& P.Lehm. are vegetatively very similar to $V$. odorata and dried specimens are difficult to tell apart. However, V. karen-chistianae has falcate leaves, with the apex recurved, sometimes becoming uncinate, thus appearing truncate, whilst $V$. odorata has leaves mostly with parallel margins and an acuminate apex. The two species are easily distinguished florally, $V$. karen-chistianae has a deeply emarginated lip apex (vs. shortly emarginated to acute), a conspicuously taller penicillate callus, $>6 \mathrm{~mm}$ tall $(v s .<5 \mathrm{~mm})$, the veins of the lip thickened with long, papillose hairs, taller towards the apex (vs. veins glabrous to warty), margins irregularly crenate ( $v s$. lacerate to fimbriate).

After the death of Thaddeous Haenke (1761-1816), the specimens collected during his expeditions in America were bought by Kaspar Maria von Sternberg, founder of the Czech National Museum in Prague (housing the PR herbarium). The collection of Haenke was mainly processed by Carl Borivoj Presl (17941852), who brought some of the Haenke's material to his home for studying. After his death, the collection kept at Presl's home was bought by the Charles University (housing the PRC herbarium) (Mráz, pers. comm. 2020). Haenke's original collection therefore ended up preserved in two different herbaria; PR and PRC. We were able to locate four specimens with Haenke's original material of Vanilla odorata, three at PR and one at PRC. Garay (1978) attempted to lectotypify Vanilla odorata selecting material at PR, but without specifying which of the three specimens currently kept there. Two specimens are determined as V. odorata in Presl's handwriting, PR-305753 and PRC-450948. Both sheets bear mixed collections made up of $V$. odorata mixed with what appears to be a species of genus Dimeranda Schltr. We select the two leaves and fruits on the left side of the sheet at PRC as lectotype (Fig. 30).

Garay (1978) also typified V. ensifolia, a synonym of $V$. odorata, citing material at $\mathrm{K}$ and $\mathrm{P}$. But again failed to specify which specimen he selected as lectotype precisely. The sheet of $V$. ensifolia at K (K000463744; Fig. 31) includes two different collections, a dried plant collected by Goudot in Cauca, Colombia (with a duplicate at P), and a drawing of a flower from a specimen in the herbarium of the Pharmaceutical Society. Both elements are cited in the protologue, but we are unable to confirm that the illustration, which was done afterwards by a third party, is indeed based on Goudot's original material. Considering that the author explicitly states he described the species based on dried specimens and that the sketch was not made by him, we designate Goudot's dried specimen of as lectotype, considering the illustration as material form a different collection.

Vanilla fimbriata Rolfe resembles $V$. odorata, $V$. insignis Ames and $V$. labellopapillata A.K.Koch, Fraga J.U.Santos \& Ilk.-Borg. It is excluded from the synonymy of $V$. odorata pending a thorough inspection of the original materials.

8. Vanilla phaeantha Rchb.f., Flora 48: 274. 1865. Fig. 37B, 38-42. Vanilla planifolia var. macrantha Grisebach, Vcat. Pl. Cub. 267. 1866.

TYPE: CUBA. C. Wright 3351 (lectotype designated here: K-000463762!, Fig. 38, specimen on the left; isolectotypes: W-43472!, illustration; AMES00090738!, specimen on the left; MO-2056007!, segment in top left corner; G-00190805!, specimen on the far right; GOET-008712!, flower; MA-607142!, top, center segment; BM-000062803!; Fig. 39). 


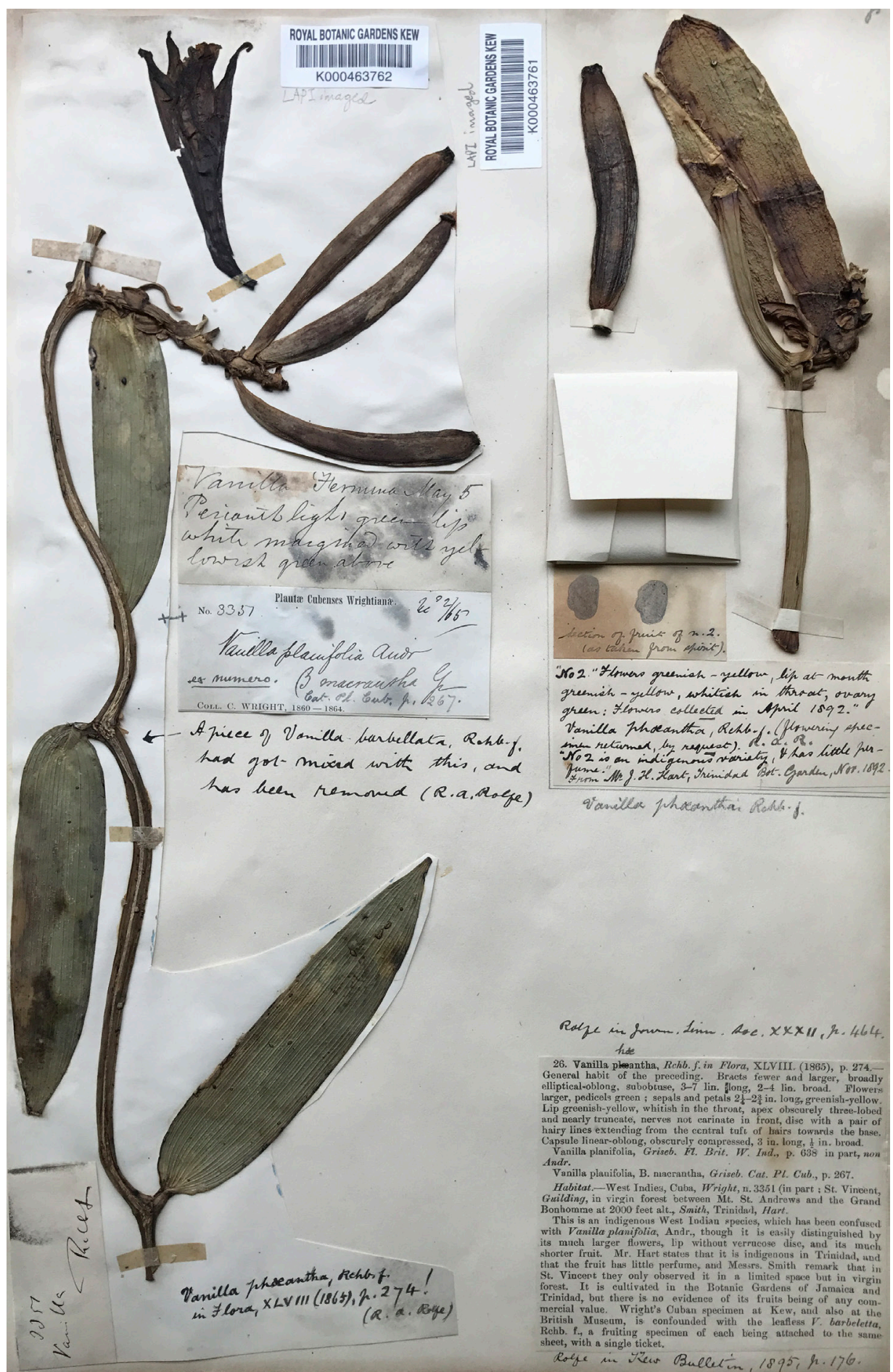

FigURE 38. The type of Vanilla phaeantha Rchb.f. is a mixed collection based on Wright 3351. A handwritten note by Rolfe explains he has removed a piece of $V$. barbellata from the sheet K-000463762 at Kew. The specimen on the left is here selected as lectotype. Photograph by APK. 


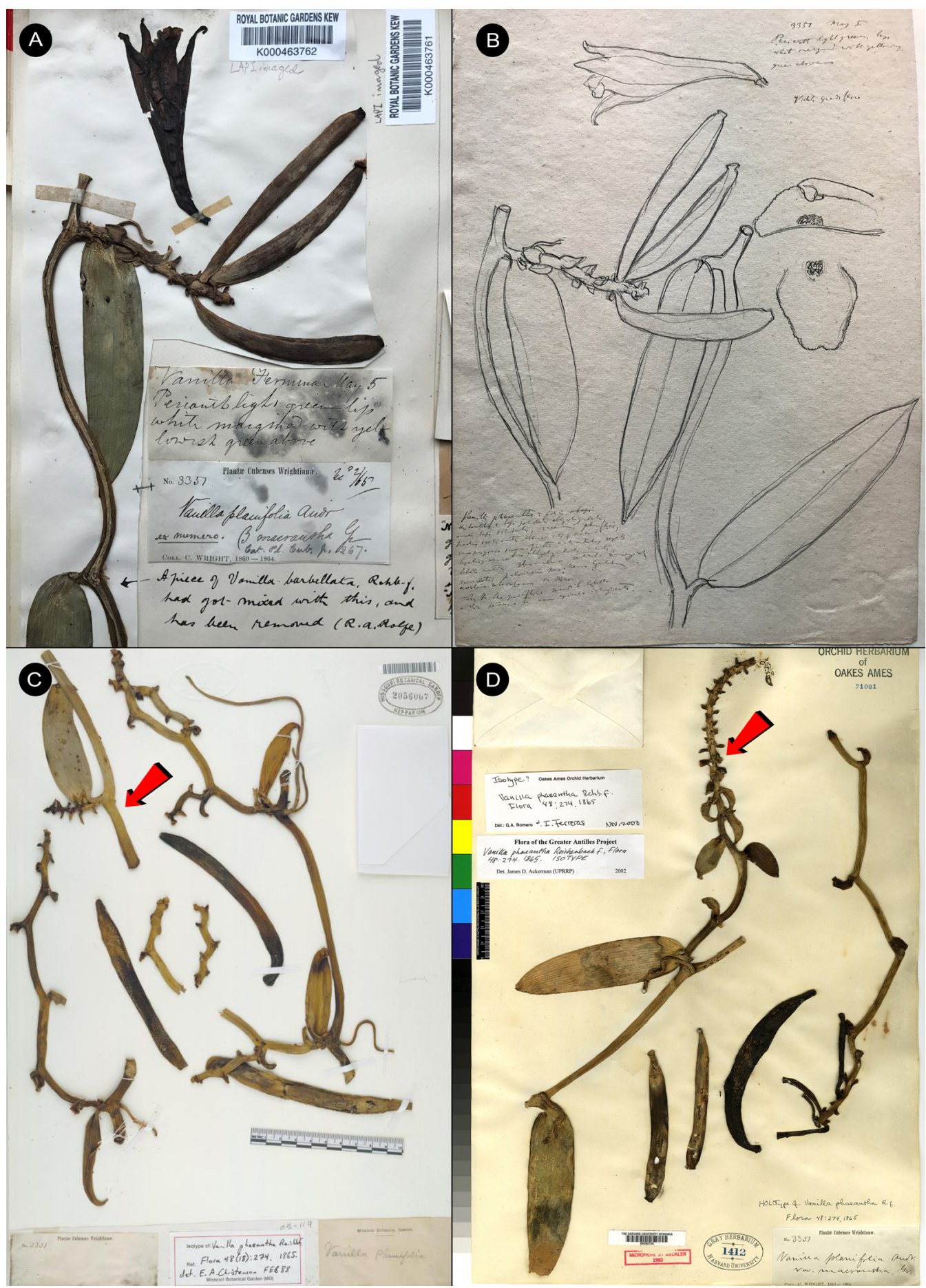

Figure 39. Type material of Vanilla phaeantha based on Wright 3351. A. Lectotype at Kew (K). B. Sketch of $V$. phaeantha at Vienna (W). C. Isotype at MO, the red arrow indicates the piece that belongs to this species. D. Isotype at AMES, the red arrow indicates the piece that belongs to this species. A-B photographs by APK; C, C copyright of Missouri Botanical Garden, Saint Louis; D, (c) copyright of Harvard University, Cambridge. 


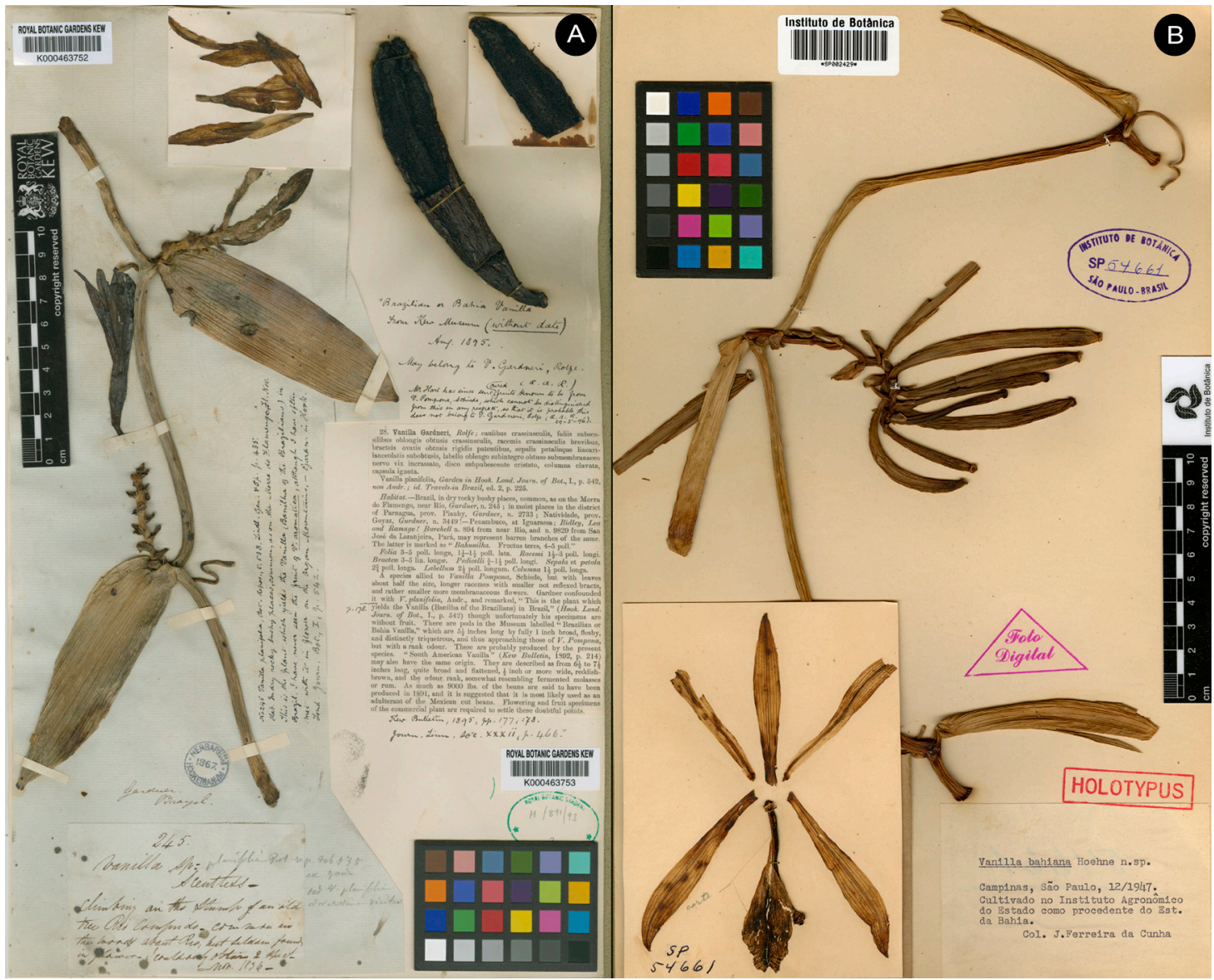

FiguRE 40. Vanilla phaeantha. A. Lectotype of Vanilla gardneri Rolfe based on Gardner 245 at K (C) copyright of the Board of Trustees of the Royal Botanic Gardens, Kew. B. Type of Vanilla bahiana Hoehne based on Ferreira da Cunha s.n. courtesy of the Herbário do Instituto de Botânica (SP).

Syn.: Vanilla gardneri Rolfe, Bull. Misc. Inform. Kew 1895: 177. 1895, syn. nov.

LECTOTYPE: BRAZIL. Morro do Flamengo, near Rio de Janeiro, Gardner 245 (K!, Fig. 40aA; SYNTYPES: BRAZIL. Parnagua District, Piauhy Prov., Gardner 2733 (K!); Natividade, Goyaz, Gardner 3449 (K!). Pernambuco, at Igarassu, Ridley, Lea \& Ramage s.n. (K, not found); near Río, Burchell 894 (K!); San José da Laranjeira, Pará, Burchell 9829 (K!).

Syn.: Vanilla bahiana Hoehne, Arq. Bot. Estado São Paulo, 2(5): 108, pl. 43. 1950, syn. nov.

TYPE: BRAZIL. Zona litorânea da Bahia, Nov 1947, Ferreira da Cunha s.n. (SP-54661!, Fig. 40B).
Hemiepiphytic vine, branching, leafy. Stems waxy, terete, smooth, green, 5-12 mm; internodes $8-15 \mathrm{~cm}$ long. Aerial free roots terete, pale brownish, up to $10 \mathrm{~cm}$ long, ca. $3 \mathrm{~mm}$ thick; attaching roots strongly flattened up to ca. $5 \mathrm{~mm}$ wide. Leaves subsessile, the petiole twisted, canaliculate, up to $8 \mathrm{~mm}$ long; blade oblong to narrowly oblong, base rounded-subcordate, apex acute-apiculate to obtuse, chartaceous (xeromorphic), green, margins revolute, $10.3-19.0 \times 2.2-5.0 \mathrm{~cm}$. Inflorescence a raceme of 2.5-4.5 cm long, ca. 4-6 mm thick, peduncle 15-29 mm long, rachis $11-15 \mathrm{~mm}$ long, producing 4-6 flowers sucessive, 1 open at once, ephemeral. Flowers with the segments spreading; tepals greenish-white, lip white yellowish to white greenish stained with yellowish, greenish or brownish at edges. Ovary straight to arcuate, subterete, smooth, 
$42-50 \times 4-5 \mathrm{~mm}$. Dorsal sepal long oblanceolate, 62-74 × 10.5-14.0 mm, blade concave, ca. 12-veined, smooth, fleshy; base long unguiculate, attenuate, canaliculate, the claw 20-25.0 $\times 3.0-5.0 \mathrm{~mm}$, apex acute-subacute, subcalyptrate. Lateral sepals strongly oblique, long oblanceolate, arcuate, $58-74 \times 12.0-15.0$ $\mathrm{mm}$, blade concave smooth, fleshy, ca. 14-veined, base long unguiculate, attenuate, canaliculated, claw ca. 22 $\times 5 \mathrm{~mm}$; apex acute, subcalyptrate and minutely warty abaxially to the apex. Petals long linear, arcuate, slightly sigmoid, $61.0-75.0 \times 8.5-14.0 \mathrm{~mm}$, ca. 10-veined; base long attenuate, canaliculated distally, with an elevated axial, flat keel abaxially ending in a triangular, acute, terminal process ca. $1 \mathrm{~mm}$ long; apex subacuteobtuse. Lip attached to the column along the margins of the basal half (42-52 mm), tubular, trumpet-shaped, conspicuously cymbiform, deepest near the middle, axially grooved on the lower surface, $70-85 \times 40-45$ $\mathrm{mm}$; unguiculate, the claw canaliculate, minute lanate, 26-35 × 3-5 mm; the blade flabellate, ca. 36-veined, somewhat trilobed, lateral lobes rounded, oblique, elevated surrounding the de column, overlapping, margins slightly undulate; mid lobe small, 5-8 $\times 11-$ $15 \mathrm{~mm}$, conspicuously reflexed, transversally oblong, revolute, margins slightly undulate, apex emarginate; penicillate callus at $40-60 \mathrm{~mm}$ from the base, made up by ca. 12 congested, retrorse, approximately trapezoidal, fimbriate scales, the scales regularly united each to other along the lateral margins, ca. $9.0 \times 5.5-$ $6.0 \mathrm{~mm}$, followed by apical thickened and warty veins forming a low inconspicuous callus. Column elongate, conspicuously sigmoid, $51-70 \times 5 \mathrm{~mm}$; ventral surface lanuginose towards the apex, below the stigma; apex dilated, vertical wings somewhat bilobed, the lower lobe falcate, ca. $2.0 \times 3.5 \mathrm{~mm}$. Stigma trilobed, with a convex, midlobe, ca. $3.0 \times 4.5 \mathrm{~mm}$, lateral lobes transversely oblong. Anther versatile, attached to the clinandrium margin, yellowish, $4 \times 5 \mathrm{~mm}$, subquadrate Pollen not forming a clear pollinarium but a sticky, tow soft, granular mass.

SPECIMENS STUDIED: UNITED STATES OF AMERICA. Florida, Fahakahatchie [Fakahatchee], 10 Jun. 1904, A.A. Eaton 1129 (AMES-02031237!; AMES-02031238!; AMES-02031239!; AMES-02031240!; AMES-02031241!; AMES-02031242!; AMES-02031243!; NY!; BM; K). Everglades, K. Bradley s.n. (JBL, photograph!; Fig. 41A). MEXICO: Yucatán, S. Villanueva-Viramontes s.n. (Photograph in Villanueva-Viramontes et al. 2017!). CUBA:
Camagüey, Sierra de Cubitas, 27 Abr. 1986, Еленевская Л. 1480 (MW-0572988!). Santa Clara, Soledad, Cienfuegos, 21 Sep. 1927, J.G. Jack 5474 (NY!). Santa Clara, Soledad, Cienfuegos, 20 Feb. 1927, J.G. Jack 4775 (NY!; AMES). Ranchuelo, pueblo entre Cienfuegos y Santa Clara, Dec. 1902, E. Cuesta 611 (NY!). Santa Clara, near Guanabana, 260 m, 28 Feb, 1 Mar. 1910, N.L. Britton, F.S. Earle \& P. Wilson 4740 (NY!). Oriente, Bayate, Sabana Miranda, 1 Jun. 1915, E.L. Ekman 5853 (NY!). Oriente, forest about Paso Estancia, Apr. 1909, J.A. Shafer 1567 (NY!). Pinar del Río, Río Guao, 26, 27, Feb. 1911, N.L. Britton, E.G. Britton \& J.F. Cowell 9639 (NY!; AMES). Pinar del Río, Sierra de Cabra, on Guane Road, 9, 11, Sep. 1910, N.L. Britton, E.G. Britton \& C.S. Gager 7274 (NY!). Pinar del Río, 24 Apr. 1903, J.A. Shafer 316 (NY!). Camaguey, vicinity of La Gloria, Feb. 1909, J.A. Shafer 201 (NY!). Matanzas, Valley of the San Juan, 18 Mar. 1903, N.L. Britton, E.G. Britton \& J.A. Shafer 407 (NY!). JAMAICA: December 4, 1891, W. Faucett 2 (K!). Dolphin head and vicinity, 200 m, 17 Mar. 1908, N.L. Britton \& A. Hollick 2201 (NY!). TRINIDAD \& TOBAGO: Aripo Savannah. December 12, 1952, R.E.D. Baker 14733 (K!). July 4, 1911, W.E. Broadway 4427 (K!). Trinidad, Nov. 1892, Hart 2 (K-000463761!). Gasparee Island, 13 Mar. 1920, E.G. Britton \& D. Coker 555 (NY!; AMES). MARTINIQUE: (BM-000062803!). COSTA RICA: Puntarenas, Buenos Aires, Potrero Grande. Clavera, Camino a la Quebrada Palacios y regiones de Sabanas, $A$. Karremans 7045 (JBL-spirit!, Fig. 42). Alajuela, April 15, 1925, O.F. Cook s.n (SEL!). PANAMA: Brushy slope; large herbaceous vine, common, Tumba Muerto Road, near Panamá, January 6, 1924, P.C. Standley 29731 (AMES31439!). Balboa, "Tapia", alt sea level, grows out in much sunlight, sepals \& petals pale green; lip white with stain of brownish color at edge, flowers in April, 1924, C.W. Powell 412 (AMES-28219!). Common, sea level, February 1924, epiphyte, Hort. Powell 137, C.W. Powell 3507 (AMES28290!). Bismark above Panama, Fls. nearly white except greenish apex; climbing on trees several yards, March 12, 1908, R.S. Williams 588 (NY!; US-678159!). Ancon Hill, June 4, 1923, W.R. Maxon 6779 (AMES-33689!; US1180005). COLOMBIA. Santander, Girón, 1000 m, 20 Jan. 2007, J.F. Caroprese 007 (COL-000257401!; COL000430711 !, stem with small leaves, the second stem with large leaves is $V$. pompona). Bucaramanga, Universidad Industrial de Santander, cultivos experimentales del Centro de Excelencia CENIVAM, 1010 m, 30 Abr. 2014, L. Sierra \& Y. Córdoba 004 (COL!). Cundinamarca, Guaduas, por la carretera a Dindal, $3 \mathrm{~km}$ abajo del puente sobre el Río Negro, 400-450 m, 5 Mar. 1981, R. Jaramillo, H. Bernal \& G. Chavarro 6772 (COL-000430712!; COL-000430891!). Magdalena, Tucurinca, 100-200 m, 28 Abr. 1948, R. Romero-Castañeda 1069 (COL!). Magdalena, Tucurinca, 28 Feb. 1950, R. Romero-Castañeda 2143 (COL!). Sucre, 
San Pedro, entre Juan Arias y San Pedro, 10 Sep. 1963, $R$. Romero-Castañeda 9868 (COL!). Departamento del Cesar, Chimichagua, Candelaria, Finca La Belleza, $38 \mathrm{~m}$, $9^{\circ} 11^{\prime} 57.6^{\prime \prime} \mathrm{N}, 73^{\circ} 52^{\prime 24} .8^{\prime \prime} \mathrm{W}, 2$ Jul. 2007, N. Sánchez Gómez et al. 022 (COL!). Comisaría del Vichada, entrada de raudal San Borja, Ventanas, ca. 100 m, 17 Mar. 1971, P. Pinto \& C. Sastre 1315 (COL-000430892!; COL000430808!). Bolívar, $7 \mathrm{~km}$ de Arenal, cerca de Carrizal, 21 Abr. 1966, E. Forero \& R. Jamarillo 472 (COL!). Santander, highway between Bucaramanga and Surata (km 8), $730 \mathrm{~m}$, 20 Jul. 1965, F.A. Barkley \& M. Valderama 35275 (AMES!). Vichada, Parque Nacional Natural "El Tuparro", Centro Administrativo, $5^{\circ} 20^{\prime} \mathrm{N}, 67^{\circ} 51^{\prime} \mathrm{W}$, ca. $90 \mathrm{~m}, 8 \mathrm{Mar}$. 1985, J.L. Zarucchi \& C.E. Barbosa 3637 (GH!). Cundinamarca, Tocaima, Quebrada Cachimbulo, sobre la carretera a Girardot, 500 m, 9 Jun. 1955, H. García-Barriga 15373 (AMES!). Barranquilla, Bro. Elias 1523 (F-876223!). Unknown locality, Y. Alomía s.n. (JBL, photograph!; Fig. 41C). Santander, Chicamocha, R.T. González s.n. (JBL, photograph!; Fig. 41D). VENEZUELA. Lara: Selva de galería a lo largo del río, afluente del Río Diquiva, vecindades de Puricaure, Distrito Torres. Lat. $10^{\circ} 3^{\prime} \mathrm{N}$, $70^{\circ} 25^{\prime} \mathrm{W}$, al sur de la carretera 5. Alt. 500 m, 27 Mar. 1975, J.A. Steyermark \& V. Carreño Espinosa 111705 (F1804735!). Bolívar: woods 1-10 km. NW of Upata, on road to San Felix, between Upata and Altagracia, alt. 700 m, 31 Jul. - 1 Aug. 1944, J.A. Steyermark 57723 (F-1250116!). La Paragua, riachuelo Surama, alt. 70 m, 8 Mar. 1940, L. Williams 12514 (F-1079459!). Zulia: Ecoparque "Ojo de Agua El Cardón", J.J. Ferrer-Paris s.n. (JBL-photo!, Fig. 41B). BRAZIL: Schott 4684 (W!). Brazil (W-21468; W-3472!). Distrito Federal, Brasília. Estação Ecológica do Jardim Botânico de Brasília. Centro Oeste, 22 Sept. 2006, A.H.Salles, 4268 (RB-00672307!). Espírito Santo, São Mateus. Ilha de Guriri, 15 Dec. 1996, M.C.F. Jesus 90 (VIES-016203!). Bahia, ILHÉUS. Estrad de acesso a Vil Brasil. Livença/Vila Brasil.acesso a esquerda pelo areial que passa por um depósito de lixo. Área antropizada, 30 Jun. 2000, F. S. Juchum 42 (CEPEC-00085923!). Brejões. Rod. Amargosa/Brejões ca. 28Km. Margem da Rodovia, 25 Feb. 2000, J. Jardim 2917 (CEPEC-00088412!). Bahia, PORTO SEGURO. Praia de Taípe. Ca. 10Km de Arraial d'Ajuda,, 02 Mar. 1981, S. C. Sant'Ana 1044 (CEPEC-00093777!). Bahia, Entre Rios. Fazenda Rio do Negro. Residual stands of the Atlantic Forest of the Rio do Negro valley, ca. $15 \mathrm{~km}$ southeast of Entre Rios. 08 Feb. 2012, A.V. Popovkin 1054 (HUEFS-182533!). Espírito Santo, Linhares. Pontal do Ipiranga, 16 Jan. 1996, A.M. Assis 37 (VIES-016254!). Same locality, 18 Apr. 1996, A.M. Assis 123 (VIES-016260!). Espírito Santo, Vitória. Reserva Biológica de Camburi, 21 Jan. 1998, A.M. Assis 377 (VIES016257!). Same locality, 09 Feb. 1998, A.M. Assis 412 (VIES-016259!). Bahia, Salvador. Parque das Dunas, trilha interpretativa. Ponto $1.200 \mathrm{~m}, 15$ Nov. 2014, F.F.V.A. Barberena 334 (ALCB-008300!). Bahia, Mata de São João. Reserva Florestal de Sapiranga, 17 Dec. 2016, F.F.V.A. Barberena 395 (ALCB-038827!). Bahia, Salvador. Parque das Dunas, caminho para a Lagoa Vitória, 25 Oct. 2014, F.F.V.A. Barberena 331 (ALCB-008301!). Bahía, Santa Cruz Cabrália, 31 Oct. 1966, R.P. Belém 2811 (UB0019154 !). Rio de Janeiro, Rio de Janeiro. Capoeira velha na mata abaixo do Sumaré, 05 Apr. 1929, A. Ducke s.n. (RB-00260120!). Bahia, Nova Viçosa. Estrada para Nova Viçosa, 22 Sept. 1979, G. Martinelli 6009 (RB-00260083!; CEPEC-00017627!). Bahia, Maraú. km 14 da estrada Maraú - Ubaituba, 18 May 1985, G. Martinelli 11060 (RB00260106!). Rio de Janeiro, Rio de Janeiro. Restinga de Sernambetiba, 02 Nov. 1952, Markgraf s.n. (RB00260111 !). Rio de Janeiro, Maricá. Restinga da Barra de Maricá, 29 Mar. 1989, M.F. Freitas 34 (RB-00260098!). Bahia, Porto Seguro. Km 18 da BR-367 liga Porto Seguro/ Cabralia, 04 Dec. 1980, A. Eupunino 555 (CEPEC-00024681!). Bahia, Itacaré. Entre a praia do Farol e a Ribeira, 01 Jan. 1992, A.M. Amorim 957 (CEPEC-00056936!). Rio de Janeiro, São Francisco de Itabapoana. Gargaú, Abatedouro. Restinga de moitas, 21 Ago. 2003, C.N. Fraga 1042 (RB-00550200!). Espírito Santo, Conceição da Barra. Pontal do Sul - Ilha de Guriri, 12 Mar. 1997, M.C.F. Jesus 176 (VIES-016202!). Rio de Janeiro, Cabo Frio. Sept. 2013, D. Hottz s.n. (RB01094255!). Bahia, Valença. Ramal a esquerda da Rod. liga Valença/Guaibim, entrada Km 9, 11 Dec. 1980, L.A.M. Silva 1245 (CEPEC-00022966!). Bahia, BELMONTE. 24Km SW Belmonte, Rod. p/ Itapebi, 28 Apr. 1980, R.M. Harley 17366 (CEPEC-00010807!). Rio de Janeiro, Rio de Janeiro. Grumari, formação de restinga Pós-Praia, pista principal da praia Parque Natural Municipal de Grumari, 02 Mar. 2016, R. Linhares s.n. (RB-01111540!). Bahía, Feira de Santana. Maria Quitéria, Serra de São José, 25 Nov. 2001, C. van den Berg 857 (HUEFS-069701!). Bahia, Santa Terezinha. Serra da Jibóia, 10 Jan. 2006, C. van den Berg 1558 (HUEFS-161515!). Bahia, Santa Terezinha. Morro da Pioneira, Serra da Jibóia, 13 Dec. 2009, C. van den Berg 1954 (HUEFS-161348!). Bahia, Inhambupe. BR-110, R.P. Orlandi 152 (RB-00260149!). Rio Grande do Norte, Parnamirim, Loteamento Caminho do Sol, estrada Nova Paranamirim/Pium, 24 Nov. 2007, A. Ribeiro \& M. Araújo 282 (HUEFS!). Rio Grande do Norte, Pedro Velho, APA Piquiri-Una, Mata do Pilão, prox. trilha, no chão, sob o bosque, $6^{\circ} 23^{\prime} 10^{\prime \prime} \mathrm{S}, 35^{\circ} 15^{\prime} 52^{\prime \prime} \mathrm{W}, 105 \mathrm{~m}, 08$ Oct. 2017, G.S. Garcia 603 (UFRN!). Nísia Floresta, Sete Lagoas, Restinga, $6^{\circ} 00^{\prime} 46^{\prime \prime} \mathrm{S}, 35^{\circ} 07^{\prime} 03^{\prime \prime} \mathrm{W}, 21 \mathrm{~m}, 18$ Aug. 2016, V.F. Sousa 461 (UFRN!). São Gonçalo do Amarante, Área próxima ao aeroporto. Fragmento de Floresta Estacional Decidual, solo arenoso, 545'49" S, 35²3'36" W, 80 m, 23 Oct. 2016, E.O. Moura \& P.H.D. Marinho 1014 (UFRN!). Canguaretama, 


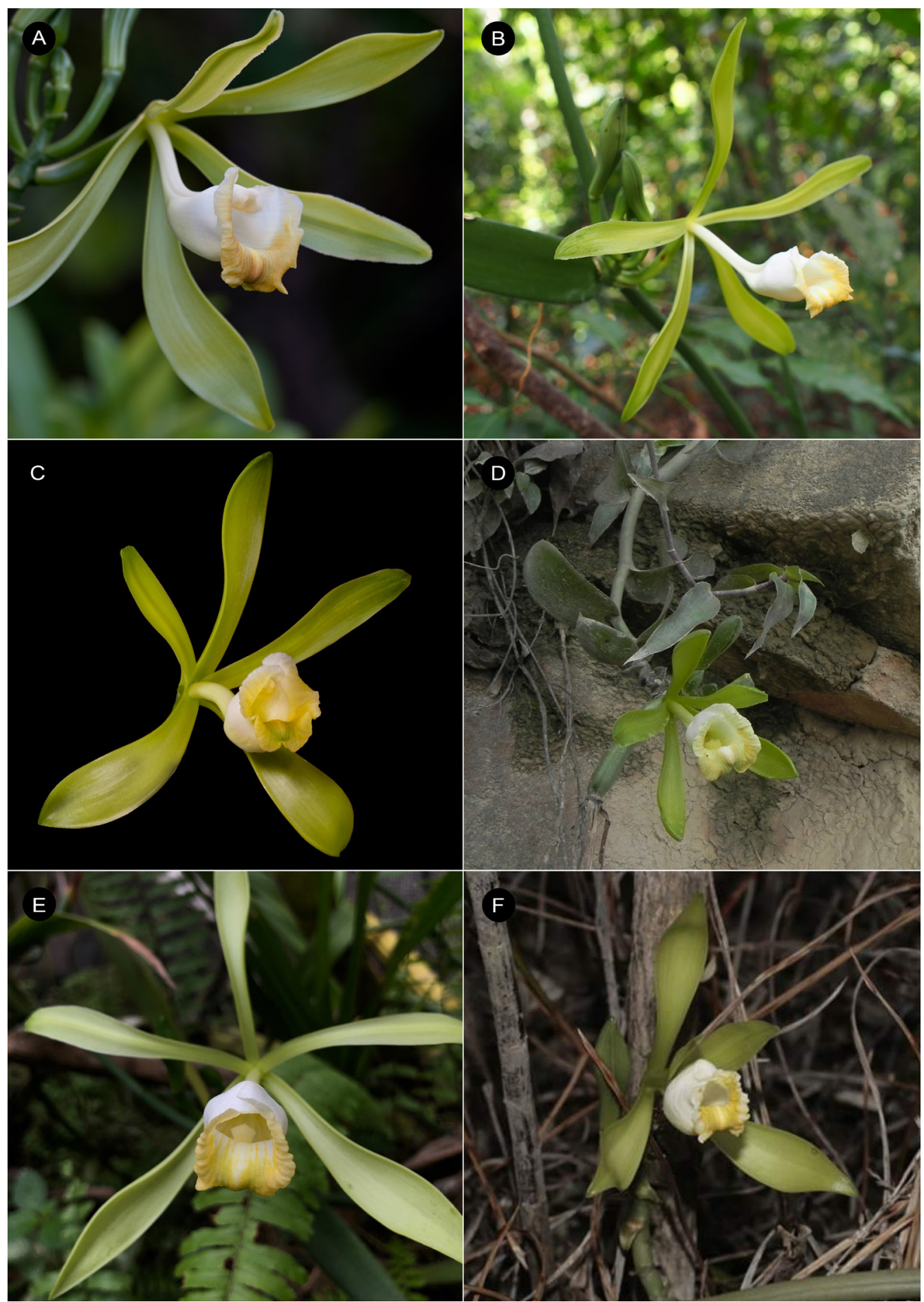

FIgURE 41. Vanilla phaeantha flowering specimens from different localities across its distribution. A. Florida, K. Bradley s.n. B. Venezuela, J. Ferrer-Paris s.n. C. Colombia, Y. Alomía s.n. D. Colombia, Santander, R.T. González s.n. E. Brazil, C. van den Berg s.n. F. Brazil, C. van den Berg s.n. Photographs by the collectors kept at JBL. 
Rod. BR 101, CA. 1,5 km N da cidadde. Tabuleiro, Mata Atlantica, 6 $20^{\prime} 37^{\prime \prime}$ S, 3510'04" W, 82 m, 19 Dec. 2010 , Jardim et al. 5864 (UFRN!). Ceará Mirim, Rod. 064, entrada na RN 309 para Pureza, ca. 4,3 km da entrada, ca. 3 $\mathrm{km}$ a leste seguindo pelo canarial, Fácie de Cerrado, $5^{\circ} 35^{\prime} 59^{\prime \prime} \mathrm{S}, 35^{\circ} 25^{\prime} 58^{\prime \prime} \mathrm{W}, 55 \mathrm{~m}, 14$ Dec. 2011, Jardim et al. 6169 (UFRN!). São Gonçalo do Amarante, Fazenda Arvoredo, ca. De $5 \mathrm{~km}$ a margem dda área do Aeroporto São Gonçalo do Amarante, em direção a comunidade Califórnia,

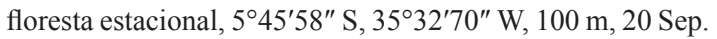
2011, J.L. Costa-Lima et al. 597 (UFRN!). Macaíba, Escola Agrícola de Jundiaí, Trilhas no tabuleiro ao lado do açude, 5०53'16" S, 35²1'21" W, 48 m, 10 Dec. 2019, V.P. Moreira 687 (UFRN!). Sergipe, São Cristóvão, $11^{\circ} 00^{\prime} 53^{\prime \prime} \mathrm{S}$, $37^{\circ} 12^{\prime} 23^{\prime \prime} \mathrm{W}, 30$ Abr. 2015, B.V. Pereira 24 (ASE!). Sergipe, São Cristóvão, $11^{\circ} 21^{\prime} 03^{\prime \prime}$ S, 37²6'54" W, 4 Mar. 2016, B.D. Silva \& E. Santos 67 (ASE!). Sergipe, Pacatuba, Rebio de Santa Isabel, $3^{\circ}$ barreta após a sede, restinga, 10³9'17" S, 36 $6^{\circ} 5^{\prime} 11^{\prime \prime}$ W, 21 Feb. 2013, E.V.S. Oliveira \& E.S. Ferreira 168 (ASE!). Pernambuco, Igarassu, Mata Atlantica, Fragmento Chavem 24 Nov. 2009, E. Pessoa \& J.A.N. Souza 150 (RB!). Goiás, Colinas do Sul. Estrada de acesso ao rio Preto, $\mathrm{km} \mathrm{6}$, a partir da entrada da fazenda Vale das Araras, $13^{\circ} 42^{\prime} 50^{\prime \prime} \mathrm{S}, 48^{\circ} 08^{\prime} 07^{\prime \prime} \mathrm{W}, 320$ m, 15 Oct. 2001, G. Pereira-Silva 5572 (CEN-43860!; CEN-51335!). Goiás, Luziania, Fazenda Corumbá (Prop. João Mariano Machado), margem direita do rio Corumbá, 11 Jun. 2003, G. PereiraSilva 7912 (CEN-78536!). Goiás, Luziania, Fazenda Corumbá (Prop. João Mariano Machado), margem direita do rio Corumbá, 11 Jun. 2003, G. Pereira-Silva 7913 (CEN63255!). Tocantins, Palmeirante, Estrada Palmeirante Itacajá, 07³6'34" S, 4752'36" W, 211 m, 28 Aug. 2008, A.A. Santos et al. 3025 (CEN!). Minas Gerais, UNAI, Mata à direita da ponte de madeira (acesso para Palmital), margem esquerda do rio Preto, $16^{\circ} 12^{\prime} 14^{\prime \prime} \mathrm{S}, 47^{\circ} 20^{\prime} 03^{\prime \prime} \mathrm{W}, 17$ May 2002, A.A. Santos et al. 1241 (CEN!). Minas Gerais, UNAI, Ilha a montante do túnel de desvio, cerca de $500 \mathrm{~m}$ da ponte de madeira. Margem esquerda do rio Preto, $16^{\circ} 12^{\prime} 18^{\prime \prime} \mathrm{S}$, 47²0'11" W, 12 Sep. 2002, A.A. Santos et al. 1508 (CEN!). Minas Gerais, Araguari, próximo a região do Córrego do Salto, estrada Araguari - Indianópolis, 5 Oct. 2016, W.M. Silva, C.F. Francisco \& S.C. Augusto s.n. (HUFU!). Mato Grosso: Itaúba, Resgate de Flora da UHE Colíder, Lote G de supressão, 10 Oct. 2015, fl., M.E. Engels 3755 [HERBAM, MBM, illustration and photographs in Engels et al. (2020)!]. Bahia, Salvador, Área de Proteção Ambiental das Lagoas e Dunas do Abaeté, F.F.V.A Barberena \& L.V. Aguiar 334 [ALCB, photographs in Anjos et al. (2016)!]. Maranhão: Caxias, Área de Proteção Ambiental Municipal do Inhamum (APA Inhamum), M.S. de Oliveira et al. s.n. [photographs in Ferreira et al. (2017)!]. Bahía, C. Van den Berg s.n. (JBL, photograph!; Fig. 39E). Bahía, C. Van den Berg s.n. (JBL, photograph!; Fig. 41F).
OTHER SPECIMENS: MEXICO: Yucatan. Cenote Mucul, Cerca de Sotuta, selva baja caducifolia, ca. $100 \mathrm{~m}$, G. Carnevali 4885 (cultivated specimen, not preserved). Quintana Roo: Mpio. Othón P. Blanco, Ejido Caobas, alrededores de la Sabana del Jaguactal, unos $21 \mathrm{~km}$ al sur de la carretera principal Xpujil-Chetumal, A. Cibrián, R. Jiménez, G. Carnevali 21, 23 (AMO-sterile). CUBA: Limones, 8 May 1926, W.R. Singleton s.n. (AMES). Limones, 8 Jun. 1926, W.R. Singleton s.n. (AMES). Limones, 14 Apr. 1926, W.R. Singleton 862 (AMES). Soledad, 1904, R.M. Grey s.n. (AMES). Pinar del Rio La Cajálbana, La Mulata, 14 Apr. 1953, J. B. Acuña Galé et al. 18508 (AMES). ST. VINCENT: Guilding s.n. (K); H.H. \& G.W. Smith 1336 (K). PANAMA: Panama. Vine climbering up trees in low thicket. Farfan Beach; roadside thicket adjacent to beach. 30 March 1969, J.D. Dwyer, L.N. Durkee \& J.R. Castillón 4691 (MO-980689). Climbing vinelike on the Farfán Beach area, forward dune-high beach community, 18 June 1971, R.L. Lazor 5358 (SCZ-2262; sterile), Veraguas: Carretera Panamericana, $4.3 \mathrm{~km}$ al $\mathrm{W}$ de El Higo, ca. $20 \mathrm{~km}$ al $\mathrm{W}$ de La Mesa, sabana de Curatella, Clethra y Roupala con selva riparia de Andira, Pithecellobium, Enterolobium y Acacia, bejuco con frutos jóvenes, extendido sobre algunos arbolitos de la sabana, hojas muy pequeñas, tallos delgados, M. Soto 9920 (PMA). BRAZIL. Maranhão: Caxias, Área de Proteção Ambiental Municipal do Inhamum (APA Inhamum), near the Inhamum stream (gallery forest),

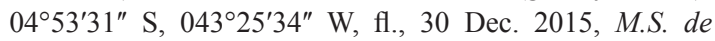
Oliveira \& E.O. Silva 02 (HENAC 151); ibid., Primavera

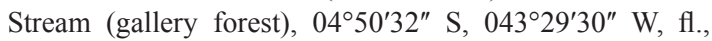
27 Oct. 2016, M.S. de Oliveira \& E.O. Silva 05 (HENAC 154); ibid., fr., 31-Dec. 2016, M.S. de Oliveira; E.O. Silva \& A.W.C. Ferreira 07 (HENAC 156).

Distribution: Very broadly distributed in the Neotropics, where it is known from U.S.A. (Florida), Mexico, Costa Rica, Panama, Cuba, Jamaica, Dominican Republic, Martinique, Trinidad \& Tobago, Colombia, Venezuela and Brazil (Fig. 37b).

\section{EXTENT OF OCCURRENCE: 14,046,406.026 km².}

Vegetatively, Vanilla phaeantha can be recognized by the robust plants with internodes generally longer than the leaves. The leaf is typically oblong to narrowly oblong, with the margins and apicule revolute. The large flowers, with their long, spreading segments, are very characteristic; the tepals are yellowish-green, with a white lip, that is stained with yellow, green or brown apically. The column has a conspicuous bend above the middle, which can be easily observed even in dried specimens. The trumpet-shaped lip has a broad obovate-rhomboid blade with undulate margins. 


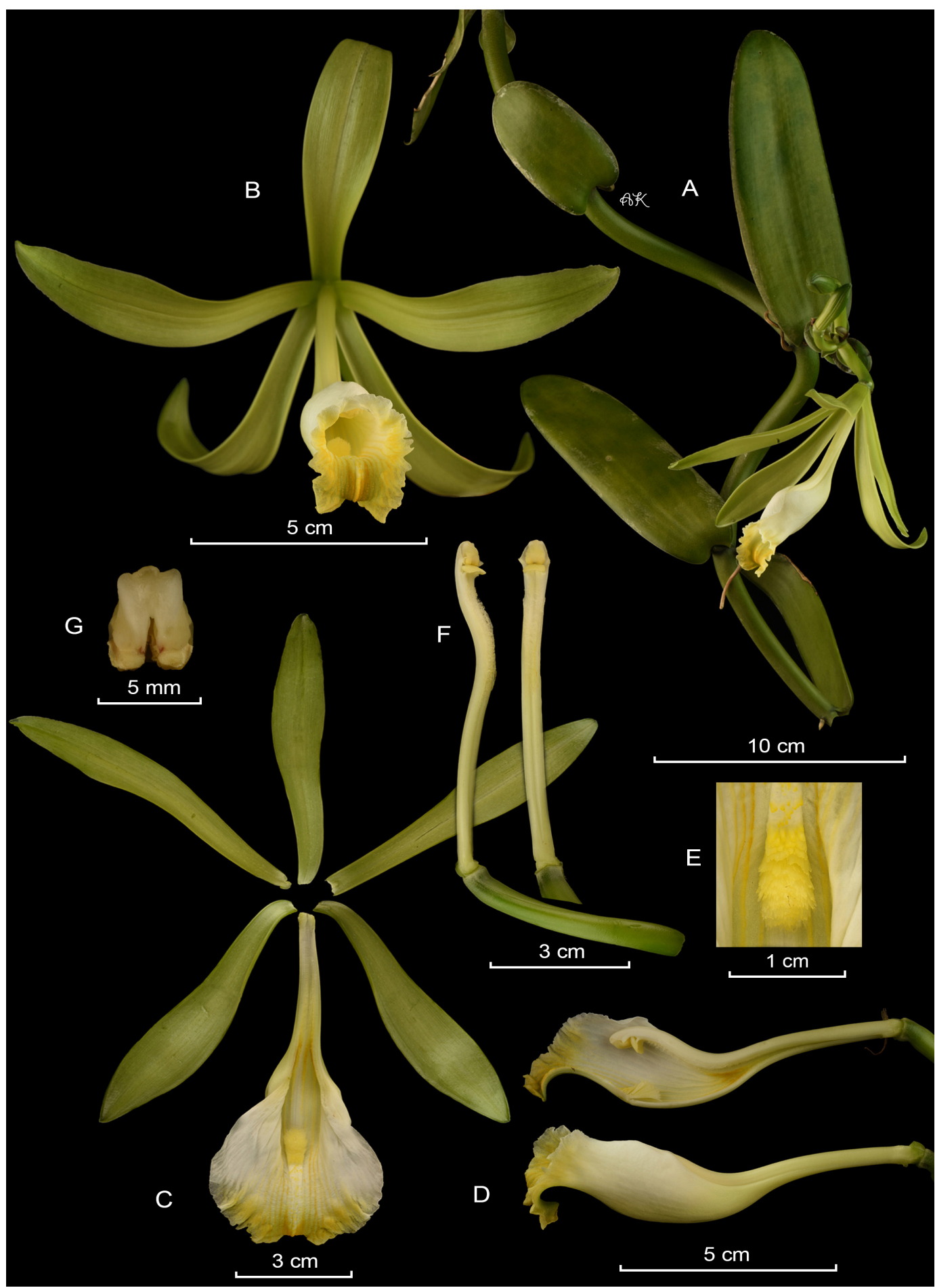

Figure 42. LCDP of Vanilla phaeantha. A. Habit. B. Flower. C. Dissected perianth, flattened. D. Lip and column lateral view. E. Callus. F. Column, ventral and lateral view.G. Anther cap and pollinia. By AK based on Karremans 7045 (JBL-spirit) from Costa Rica. 
Reichenbach described $V$. phaeantha on the basis of Wright 3351. Unfortunately, different Vanilla species from Cuba were distributed under that number to diverse herbaria. However brief, the description corresponds well with the sketch determined as $V$. phaeantha in his herbarium (W-43472, Fig. 39B), and which was clearly based on the specimen at Kew (K-000463762, Fig. 38, 39A). The latter is therefore selected as lectotype. On the specimen is a note by Rolfe indicating that "A piece of Vanilla barbellata Rchb.f. had got mixed with this, and has been removed". Indeed, the isolectotypes at AMES (Fig. 39D) and MO (Fig. 39C) consist of two different species of which only parts are $V$. phaeantha (indicated with an arrow); also mixed are the specimens at $\mathrm{G}$, GOET and MA (MA-607142). None of the elements found on the Wright 3351 specimen kept in Paris (P00128658) and Madrid (MA-607143) seem to belong to Vanilla phaeantha and that material is therefore excluded.

Vanilla gardneri is another cryptic taxon that has long been a source of confusion. Rolfe (1895) cited six different collections as syntypes of this taxon. Four of them, Gardner 245, Gardner 2733, Gardner 3499 and Burchell 894 are conspecific with the Brazilian taxon that was later described Vanilla bahiana (= Vanilla phaeantha). Whereas, Burchell 9829 belongs to a completely unrelated taxon in the Vanilla hostmannii Rolfe group. This has caused great confusion as to the identity of Vanilla gardneri, a species that has been generally treated as a member of the $V$. hostmannii group. Nonetheless, Rolfe included Burchell 9829 with doubt and his concept of $V$. gardneri clearly refers to V. phaeantha. Soto Arenas \& Cribb (2010) selected Gardner 245 as lectotype, which is congruent with Rolfe's concept of this species. As such we find the taxon to be an earlier name for $V$. bahiana, and thus conspecific with $V$. phaeantha.

Vanilla bahiana has been commonly considered a distinct species restricted to the xerophytic coastal caatinga habitats around Bahía in Brazil, whereas $V$. phaeantha has been generally believed to be restricted to North and Central America and the Antilles. It is said to differ from $V$. phaeantha in the smaller flowers and more well defined three-lobed lip (Soto Arenas \& Cribb 2010). Nevertheless, we find that the morphological features found in plants and flowers of different populations of $V$. phaeantha and $V$. bahiana fully overlap and can't find any feature that consistently distinguish the two (Fig. 41). It has now been amply confirmed that in Brazil the species is not confined to the coastal caatinga, and the species can be found growing in both xerophytic areas as semidecidous forests across its distribution. As the $V$. phaeantha range grows further south, now including Colombia and Venezuela, and the Brazilian populations keep appearing more inland the alleged gap in its distribution gets narrower (Fig. 37b). The two population are probably not as isolated as it once seemed to appear.

9. Vanilla planifolia Andrews, Bot. Repos. 8: t. 538. 1808. Fig. 43-54, 55A.

Vanilla aromatica var. planifolia (Andrews) F.Buyss., L'orchidophile; Traité Théor. \& Prat.: 513. 1878. Notylia planifolia (Andrews) Conz., Fl. Taxon. Mex. 3: 151.1947.

LECTOTYPE: WEST INDIES. The finest specimen in England, and the only one that has blossomed, is in the choice collection of the Right Hon. Charles Greville, at Paddington, from which our drawing was taken. We are informed that it is a native of the West Indies, and was introduced to this country by the Marquis of Blandford, illustration published by Andrews in Bot. Repos. 8, 1808: pl. 538 (designated by Garay \& Sweet 1974; Fig. 43).

Syn.: Araco aromaticus "Tlilxochitl seu flore nigro" [Tlilxochitl or black flower] in Rerum Medicarum Novae Hispaniae Thesaurus: 38. 1651 (Fig. 44).

Syn.: Vanilla viridiflora Blume, Bijdr. Fl. Ned. Ind.: 422. 1825.

TYPE: "Crescit: in horto botanico Buitenzorg. culta, et ex America australi allata. Floret: Septembri, Octobri" (lectotype designated here: L-0063885!, Fig. 45A)

Syn.: Vanilla sativa Schiede, Linnaea 4: 573. 1829.

TYPE: [MEXICO] Misantla, "Baynilla mansa Hispano-Mexicanorum. Hab. sponte Papantlae, Misantlae, Nautlae et Colipae inque iisdem pagis colitur", Schiede s.n. (lectotype designated here: HAL-111289!, Fig. 45B; isolectotypes: HAL110974!, Fig. 45C; BM!).

Syn.: Vanilla sylvestris Schiede, Linnaea 4: 573. 1829. TYPE: [MEXICO]. Papantla, "Baynilla cimarrona, Hispano-Mexicanorum. Hab. Papantlae, Nautlae, 


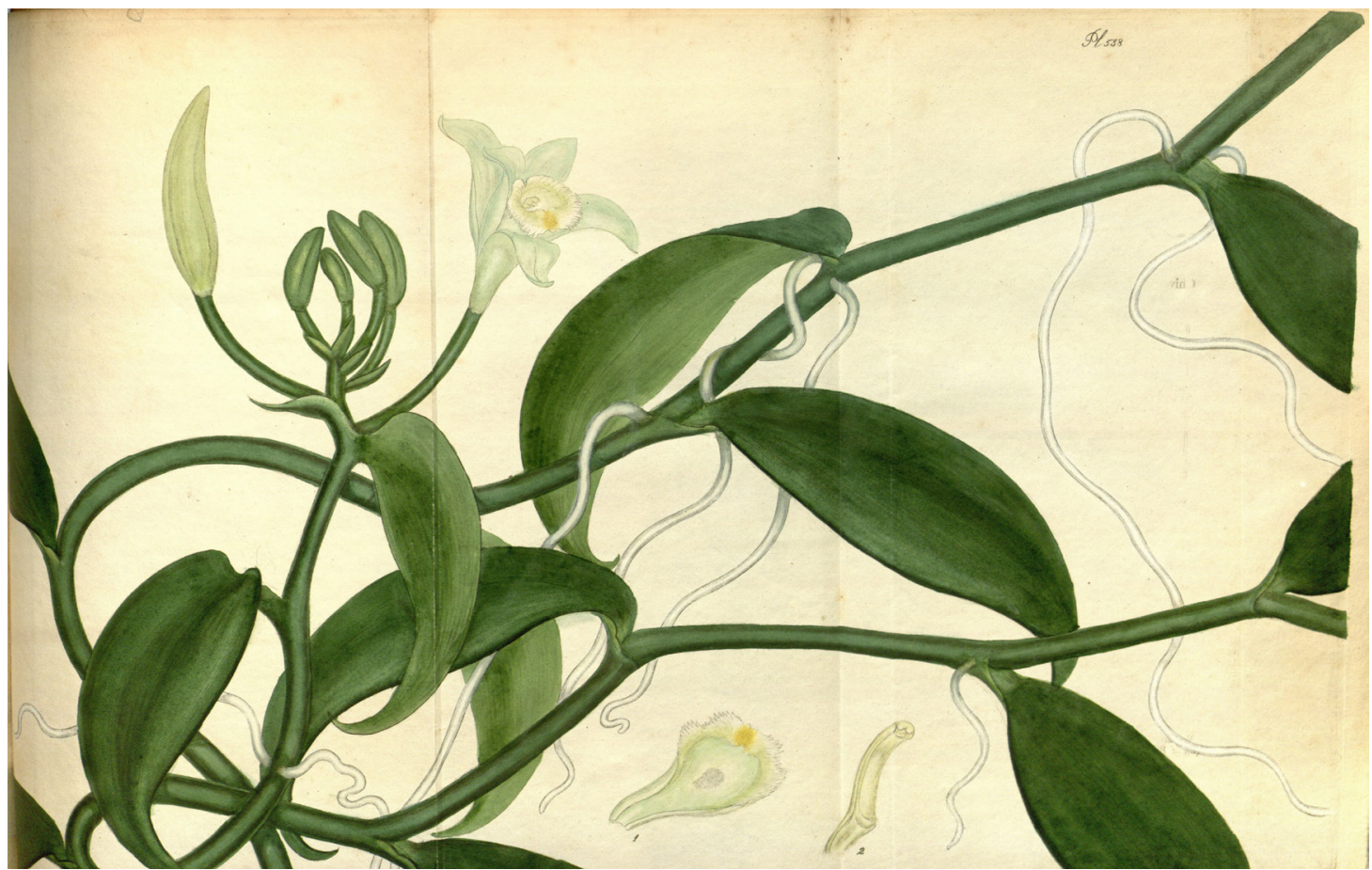

FIgURE 43. Vanilla planifolia Andrews plate 538 based on a specimen from Charles Greville, selected as lectotype by Garay \& Sweet (1974).

Colipae", Jan. 1829, Schiede s.n. (lectotype designated here: HAL-111290!, Fig. 45D).

Syn.: Vanilla schwackeana Hoehne, Arq. Bot. Estado São Paulo, n.s., f.m., 1: 125. 1944, syn. nov.

TYPE: BRAZIL. Belo-Horizonte, Minas, sem indicações e procedencia e data, Schwancke 11106 (lectotype designated here: RB-37015!, dissected flower on upper right corner, Figs. 46A, 46B).

Syn.: Vanilla bampsiana Geerinck, Bull. Jard. Bot. Nat. Belg. 52: 345. 1982.

TYPE: ZAIRE. District du Forestier central: Bikoro, forêt sèche, Lebrun 1459 (holotype, BR-840615!, Fig. 46C; isotypes, BR-840616!, K-000306647!, WAG-0002582!, WAG-0002581!).

Syn.: Vanilla sotoarenasii M. Pignal, Azof.-Bolaños \& Grisoni, Eur. J. Taxon. 284: 17-22. 2017, syn. nov. TYPE: COSTA RICA. Cahuita (ex hort. parc E. Liais, from plants collected by B. Gosselin in 1993), 8 Oct. 1996, M. Pignal $396 b$ (holotype: P-00075132!, Fig. 46D).

Hemiepiphytic, branching, leafy vine, up to several meters high. Stems dark green, subterete, smooth, flexuous, one per internode emerging laterally to the leaf, 4.5-10.0 $\mathrm{mm}$ in diameter; internodes smooth or sulcate, $1-13 \mathrm{~cm}$ long. Aerial roots subterete, 1.5-3.0 $\mathrm{mm}$ in diameter. Leaves shortly petioled; the petiole 3-13 mm long; blade elliptic to oblong or ovate, acute, acuminate, porrect to deeply recurved, sometimes becoming uncinate, coriaceous, 2.0-20.0 $\times$ 0.8-6.2 $\mathrm{cm}, 9-23$-veined. Inflorescence axillary or terminal, producing up to 26 successive flowers per raceme, 1-opened simultaneously; peduncle subterete, 0.5-7.0 $\mathrm{cm}$ long; rachis up to $1.5-10.0 \mathrm{~cm}$ long. Floral bracts green, sessile, ovate, obtuse to acuminate, concave, 4-15 $\times 3-8 \mathrm{~mm}$. Flowers with the ovary basally whitish, apically green to yellowish-green, sepals, petals and lip greenish-white to pale yellowish-green, sometimes adaxially more yellowish-green or yellowish in the apical $1 / 3$, penicillate callus whitish with the yellowish apex, column dorsally white, ventrally greenish to yellowish-white or whitish, anther dorsally yellowishgreen to yellowish, ventrally whitish, and rostellum dorsally greenish to yellowish-white, ventrally whitish; fragrance sweet. Ovary subterete, papillose, arcuate, 25-62 × 3-4 mm. Dorsal sepal oblanceolate, cuneate, 


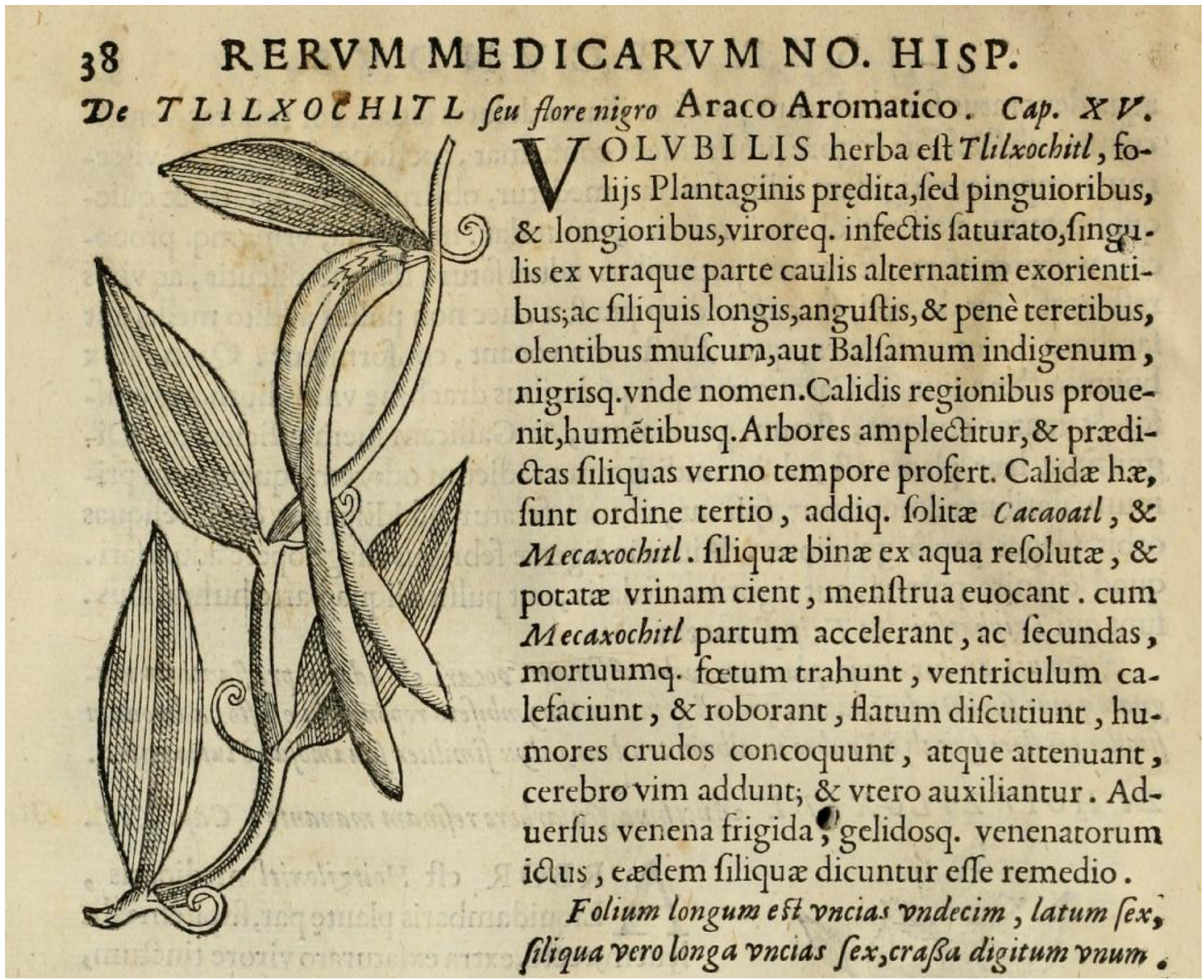

FigURE 44. Araco aromaticus "Tlilxochitl seu flore nigro" [Tlilxochitl or black flower] in Rerum Medicarum Novae

Hispaniae Thesaurus: 38 published in 1651 is one of the earliest illustrations of Vanilla planifolia.

acute, lightly concave, lightly arcuate, straight or porrect, fleshy, 7-9-veined, 40-60 × 7-12 mm. Lateral sepals obliquely oblanceolate, cuneate, acute, lightly concave, arcuate, fleshy, 7-9-veined, 43-58 × 9-12 $\mathrm{mm}$. Petals obliquely elliptic, cuneate, obtuse, lightly concave, arcuate, abaxially with an raised dorsal keel, 9-11-veined, 41-58 $\times 7-10 \mathrm{~mm}$. Lip fused to the column along the margins for $24-28 \mathrm{~mm}$, tubular, trumpetshaped, trilobed; when spread out 41-55 × 21-28 mm; unguiculate, the claw lightly arched, pubescent, 11-20 $\times$ 3-7 mm long; the blade cymbiform, when spread out flabellate in outline, 27-31-veined, the veins papillose, progressively thickened towards the apex forming grooves, branched; the lateral lobes obtuse, margins undulate, crenate to dentate or lacerate, with teeth up to $2 \mathrm{~mm}$ long; the midlobe subrectangular, emarginate to bilobed, recurved, margins undulate, laciniate to lacerate, $2-9 \times 11-12 \mathrm{~mm}$; disc with a penicillate callus 25-35 $\mathrm{mm}$ from the base, 4-6 $\times 3-4 \mathrm{~mm}$, made up by 5-7 imbricate, flabellate, lacerate scales, the proximal ones bigger, sometimes united each to other along the lateral margins; continuing apically with 5-7 rows of papillae or warts, progressively thickened and raised towards the apex. Column subterete, arcuate inward, 32$39 \times 2.7-3.0 \mathrm{~mm}$, ventrally flattened, densely pubescent below stigma, basally glabrous, smooth, lustrous, apex

Right, Figure 45. Vanilla planifolia. A. Lectotype of $V$. viridiflora Blume (L-0063885), (C) copyright of the Naturalis Biodiversity Center, Leiden. B. Lectotype of $V$. sativa Schiede (HAL-111289). C. Isolectotype of $V$. sativa Schiede (HAL-110974). D. Lectotype of V. sylvestris Schiede (HAL-111290). B-D, (C) copyright of the Martin-LutherUniversität, Halle. 


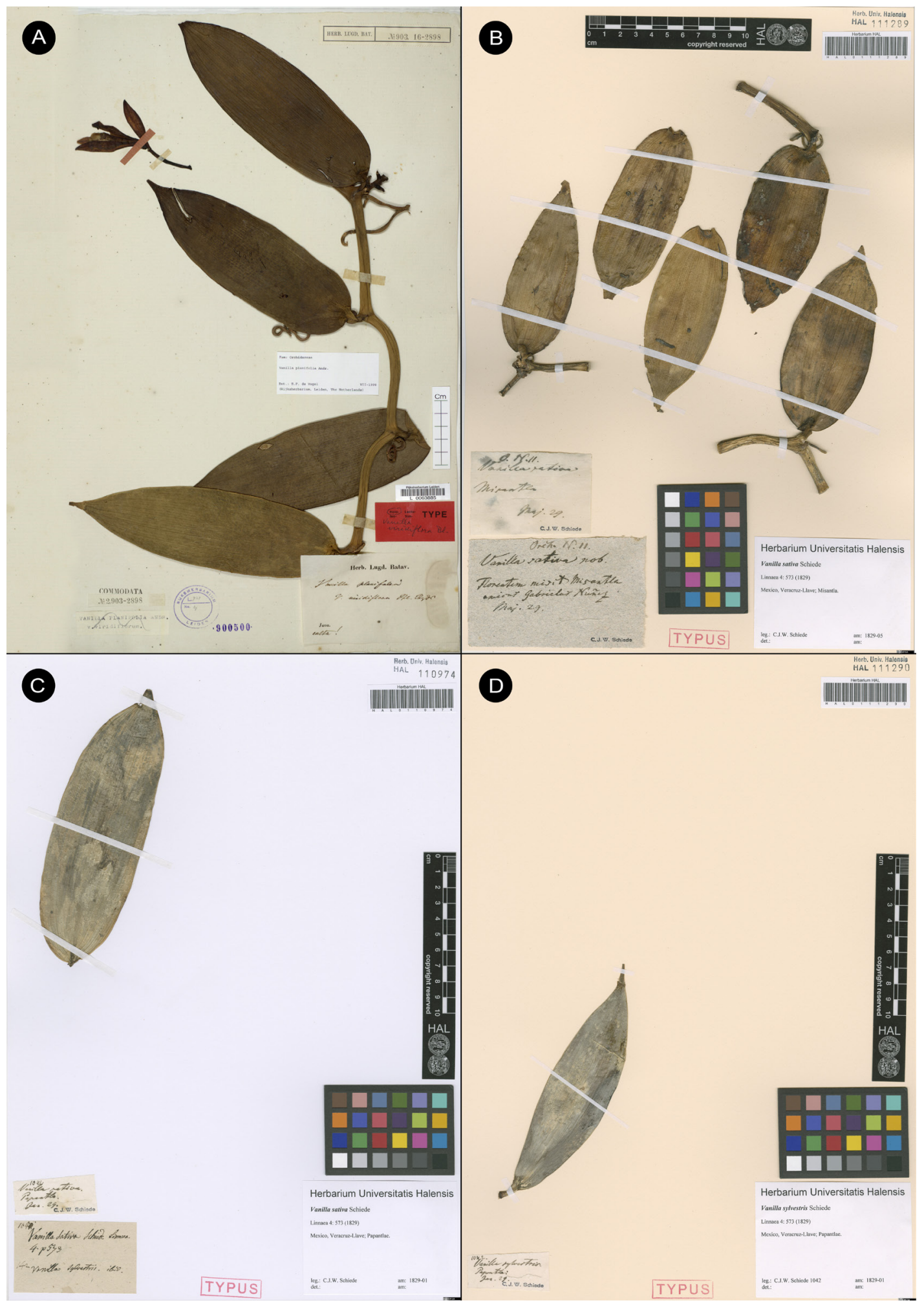



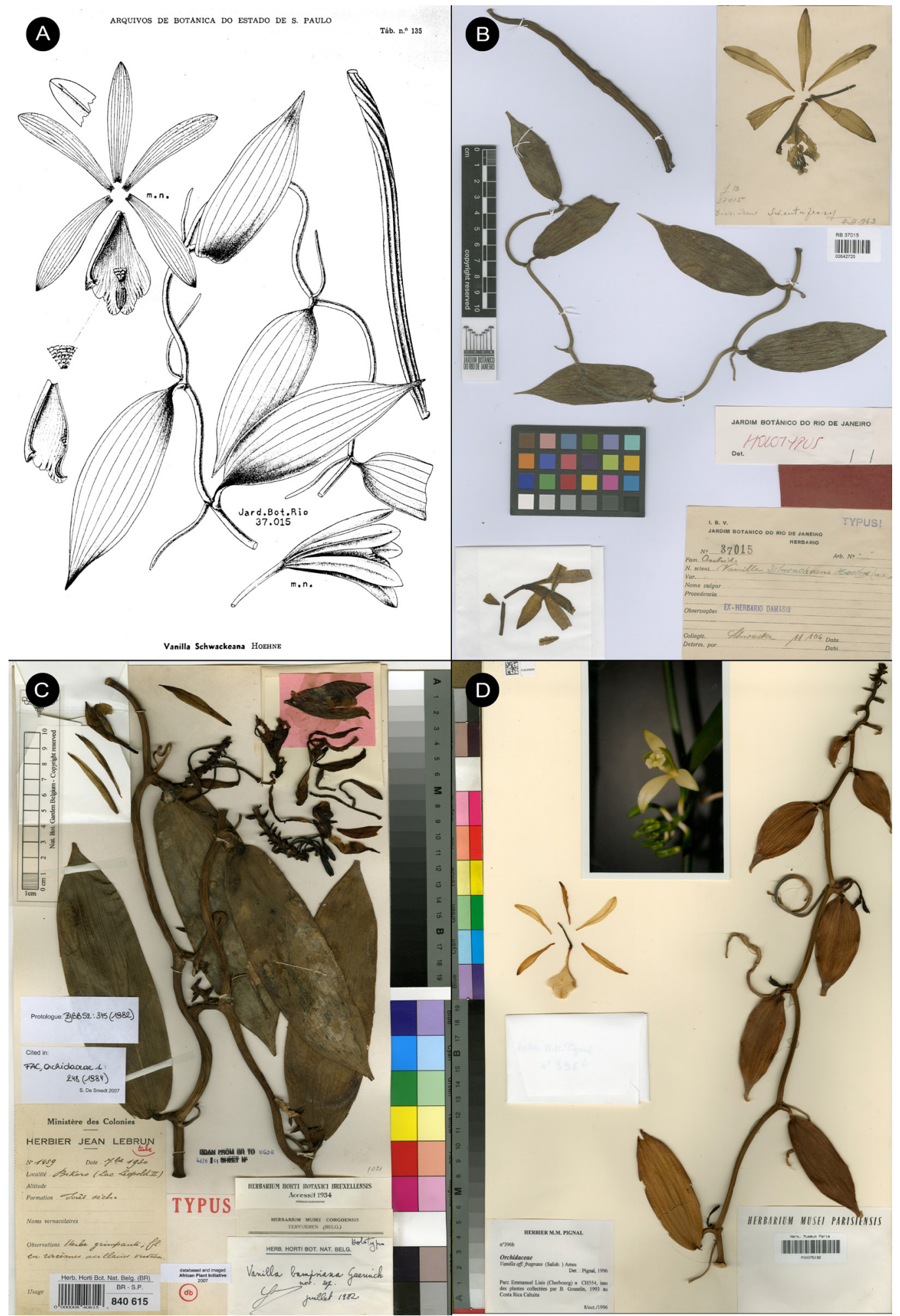
tri-winged, lateral wings obliquely flabellate, retrorse, mid-wing cucullate, rounded, $5 \times 4 \mathrm{~mm}$. Stigma trilobed, with raised lobes. Rostellum subquadrate, convex blade. Anther cap basally hinged to the clinandrium margin by a laminar, broad filament, movable, obovate, 3.0-4.2 $\times 3.1-3.5 \mathrm{~mm}$. Pollen a sticky, granular mass. Fruit green, turning yellow and then dark brown when ripe, subterete, subclavate, sometimes slightly angulate or sulcate, straight to arcuate, dehiscent, very fragrant, $6.5-30.0 \times 0.7-1.5 \mathrm{~cm}$.

SPECIMENS STUdied: UNITED STATES OF AMERICA. Hawaii: [Cultivated] Harold L. Lyon Arboretum-Middle Lawn Makai, 31 May 1968, K. Nagata 378 (L!). MEXICO: Mexico, W-Indië; Tropen, 28 May 1969, H.J. van Hattum 2290 (L!). In virgin xerophytic forests, Izamal, Apr. 1917, G.F. Gaumer \& Sons 23909 (F-466398, US-1268044, AMOphoto!). GUATEMALA: Petén. Dolores, in low forest about $2 \mathrm{~km}$. $100 \mathrm{~m}$ south of village, 3 May 1961, E. Contreras 2239 (LL; AMO-photo!). BELIZE. British Honduras. Orange Walk District. $9.9 \mathrm{~km} \mathrm{~S}$ of Program for Belize Camp., 17045 N, 8909' W, 16 May 1991, R. Arvigo 545, P. Cocom. R. Cocom, N. Romero, G. Shropshire \& J. Woodland (AMES!). Maskall, pine ridge road high ridge, collected for C.L Lundell, 3 Mar. 1934, P.H. Gentle 1234 (AMES-41360!, AMES41361!). Machasa, 50 ft. [15 m], 16 May 1934, W.A. Schipp 8-844 (AMES!). Toledo District. Temansh River, along river bank here in wet swampy places, $100 \mathrm{ft}$. [40 m], 13 Mar. 1935, W.A. Schipp S-971 (AMES!). HONDURAS. Lancetilla Valley, 150 ft. [46 m], 8 Dec. 1934, T.G. Yuncker 4993 (AMES-02158434!). EL SALVADOR. San Salvador, in garden, 15 Dec. 1922, S. Calderón 518 (AMES!, US!). NICARAGUA. Zelaya. Logging camp near Quebrada La Talolinga, ca. $11^{\circ} 51-52^{\prime} \mathrm{N}, 84^{\circ} 26-27^{\prime} \mathrm{W}, 170 \mathrm{~m}, 18$ Aug. 1983, J. Miller 1138 \& J. Sandino (MO!, SEL!). Ibo Tingni, drainage of Caño Sung Sung, N of road between Puerto Cabezas and Río Wawa; approx. $14^{\circ} 9-11^{\prime} \mathrm{N}, 83^{\circ} 29-31^{\prime} \mathrm{W}$, less than $10 \mathrm{~m}, 6$ Oct. 1978, W.D. Stevens $10667 \&$ B.A. Krukoff (SEL!). Monkey Point; beach and bluff near village, ca. $11^{\circ} 35^{\prime}$ N, $83^{\circ} 39^{\prime}$ W, 0-20 m, 7 Apr. 1981, W.D. Stevens 20021 \& B.A. Krukoff (SEL!). COSTA RICA. Cartago: Very common in forest on ridges, seen also by riverside, May 1924, C.H. Lankester 847 (AMES!). Limón: Siquirres. Barra de Parismina, $10^{\circ} 16^{\prime} 53.03^{\prime \prime} \mathrm{N}, 83^{\circ} 19^{\prime} 43.21^{\prime \prime} \mathrm{W}, 18 \mathrm{~m}, 8$ Feb. 2013, B. Azofeifa, J. Garcia and A. Paniagua 2 (CR!). Hamburg Finca, on the Río Reventazón below Cairo, $55 \mathrm{~m}$, 19 Feb. 1926, P.C. Standley 48904 \& J. Valerio (AMES!, US-
1309657!). In regione Atlantica: "Hamburg", 9 km. ab ore fluminis Reventazon inter Musas cultas, 15 m, 2 May 1930, G. Cufodontis 735 (AMES-02158453!, W-1!, W-2! [2 sheets]). Camino a Portete, 30 Jun. 1945, M. Quirós 4254 \& V. Sáenz (CR!). Talamanca, Sixaola. R.V.S. GandocaManzanillo. Sendero hacia Laguna de Gandoca. Aprox. 400 $\mathrm{m}$ de la entrada del sendero hacia la laguna, $9^{\circ} 35^{\prime} 40.9^{\prime \prime} \mathrm{N}$, $82^{\circ} 36^{\prime} 9.0^{\prime \prime} \mathrm{W}, 3 \mathrm{~m}, 11 \mathrm{Abr} .2012$, A. Estrada 5331, J. Sánchez, A. Ruiz-Boyer, S.E. Bolaños \& J. Solano (CR!). Talamanca, Cahuita. P.N. Cahuita. Sector Puerto Vargas. Sendero entre casa de administración del parque punta Cahuita. Aprox. 900 $\mathrm{m}$ de la administración, $9^{\circ} 44^{\prime} 12.6^{\prime \prime} \mathrm{N}, 8^{\circ} 48^{\prime} 38.8^{\prime \prime} \mathrm{W}, 1 \mathrm{~m}, 9$ May 2012, A. Estrada 5378, J. Sánchez, A. Ruiz-Boyer \& R. Chacón (CR!). Talamanca. Refugio de Vida Silvestre Gandoca-Manzanillo, 9॰35'41.05" N, 82 $2^{\circ} 36^{\prime} 10.30^{\prime \prime} \mathrm{W}, 16 \mathrm{~m}$, 14 Nov. 2013, B. Azofeifa \& J. García 47 (CR!). Parque Nac. Cahuita, Puerto Vargas, 12 Abr., B. Morera s.n. (USJ!). P. N. Cahuita. Faja Costeña de Limón. Sendero a Puerto Vargas, 944'20" N, 8249'30" W, 2 m, 9 Dec. 1993, E. Lépiz 87, J.L. Poveda \& V.H. Ramírez (CR-1!, CR-2! [2 duplicates]). Talamanca, Cahuita, Cahuita National Park, sector Puerto Vargas, trail from the Rangers Administrative building to Punta Puerto Vargas, $9^{\circ} 43^{\prime} 54.4^{\prime \prime} \mathrm{N} 82^{\circ} 48^{\prime} 53.5^{\prime \prime}$ W $9^{\circ} 44^{\prime} 48.9^{\prime \prime} \mathrm{N} 82^{\circ} 48^{\prime} 42.4^{\prime \prime} \mathrm{W}$, sea level, 26 Apr. 2012, F. Pupulin 8274, D. Bogarín \& M. Fernández (JBL!, Fig. 47, 51B-D). Talamanca, Cahuita, Cahuita National Park, sector Puerto Vargas, trail from the Rangers Administrative building to Punta Puerto Vargas, $9^{\circ} 43^{\prime} 54.4^{\prime \prime} \mathrm{N} 8^{\circ} 48^{\prime} 53.5^{\prime \prime} \mathrm{W}$ $9^{\circ} 44^{\prime} 48.9^{\prime \prime} \mathrm{N} 82^{\circ} 48^{\prime} 42.4^{\prime \prime}$ W, sea level, 26 Apr. 2012, F. Pupulin 8276, D. Bogarín \& M. Fernández (JBL!, Figs. 48, 51A). Talamanca, Sixaola. Área no protegida. Gandoca.

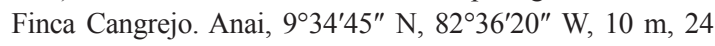
Mar. 1995, G. Herrera 7550 (CR-1!, CR-2! [2 duplicates]). Talamanca. R. V. S. Gandoca-Manzanillo. Puerto Viejo. Punta Uva, peñon innominado adyacente a la Quebrada Ernesto, $9^{\circ} 38^{\prime} 30^{\prime \prime} \mathrm{N}, 82^{\circ} 41^{\prime} 20^{\prime \prime} \mathrm{W}, 0$ a $10 \mathrm{~m}, 4$ May 2001, J.F. Morales 7967 (CR!). Pto. Vargas, Parque Nac. Cahuita, 16 Abr. 1978, J. Gómez-Laurito 3674 (USJ!). Pto. Vargas. Parque Nac. De Cahuita, 3 Set. 1978, J. Gómez-Laurito 3925 (CR!). A la orilla del bosque anegado, entre Pto. Vargas y la Punta, Parque Nac. Cahuita, ca. nivel del mar, 21 Jun. 1980, J. Gómez-Laurito 5563 (CR!). Forest between Punta Manzanillo and Punta Mona, E. of Manzanillo de Talamanca. ca. $8-12$ m, $9^{\circ} 38^{\prime} \mathrm{N}, 82^{\circ} 38^{\prime} \mathrm{W}, 2$ May 1985, M.H. Grayum 5257 \& G. Schatz (CR!, SEL!). Pococí. Refugio de Vida Silvestre Barra del Colorado, Cerro del Tortuguero, summit ridge. $10^{\circ} 35^{\prime} \mathrm{N}, 83^{\circ} 32^{\prime} \mathrm{W}$, ca. $100-119 \mathrm{~m}, 22$ Jan. 1997, M.H. Grayum 11141, B. Hammel, J. Schipper \& L. Merrill (CR!).

Left, FIGURE 46. Vanilla planifolia. A. Illustration of type of V. schwackeana Hoehne, based on Schwancke 11106. B. Lectotype dissected flower on upper right corner of RB-37015 (C) copyright of Reflora, Brazil. C. Holotype of V. bampsiana Geerinck, based on Lebrun 1459 (BR-840615), (C) copyright of Meise Botanic Garden, Belgium. D. Holotype of V. sotoarenasii M. Pignal, Azof.-Bolaños \& Grisoni, based on M. Pignal 396b (P-00075132), C copyright of the Muséum national d'histoire naturelle, Paris. 
Talamanca, Refugio Nacional Mixto de Vida Silvestre Gandoca- Manzanillo, $9.594^{\circ} \mathrm{N}, 82.602^{\circ} \mathrm{W}\left[9^{\circ} 35^{\prime} 38.4^{\prime \prime} \mathrm{N}\right.$, $82^{\circ} 36^{\prime} 7.2^{\prime \prime} \mathrm{W}$ ], altitude $2 \mathrm{~m}, 14 \mathrm{Nov} .2013$, cultivated in BRC Vatel, Saint Pierre, La Réunion, France CRV2180, 28 Feb. 2016, M. Grisoni JJMM 01 \& J.B. Azofeifa-Bolaños (REU!). Talamanca. Refugio de Vida Silvestre Gandoca-Manzanillo, 9॰35'38.4" N, 82³6'7.2" W, 14 m, 14 Nov. 2013, M. Grisoni 2180, B. Azofeifa \& J. García (CR!). Manglar de Gandoca, Limón, 24 Jun. 1983, R. Soto s.n. (CR!). Puntarenas: Aguirre [canton Quepos], Savegre. Área no protegida. Finca Rafiki, 9²6'47" N, 8359'14" W, 250 m, 7 May 2002, J. Sández 1219 (CR!). Cantón Golfito. Valle de Coto Colorado. Ribera del Río Esquinas. Boca Río Esquinas. $8^{\circ} 44^{\prime} 00^{\prime \prime} \mathrm{N}, 83^{\circ} 20^{\prime} 00^{\prime \prime}$ W, 30 m, 22 Dec. 1993, M. Segura 264 \& F. Quesada (CR!). [Canton Osa, district Sierpe] Area between the Rio Esquinas and Palmar, sea level, 2 May 1950, P.H. Allen 5532 (SEL011362!). Hamburg Finca on the Río Reventazón, 1925, F. Nevermann s.n. (MO, AMO-photo!). Heredia: Sarapiquí, La Virgen, La Tirimbina, $180 \mathrm{~m}$, planta probablemente cultivada,11 de Abril 2016, A.P. Karremans 7042, M. Cedeño, I. Chinchilla \& G. Villalobos (JBL-spirit!, Fig. 49, 51E). PANAMÁ. Barro Colorado Island. Gross-Lathrops trail, 26 Jun. 1931, L.H. Bailey 374 \& E.Z. Bailey (AMES-02158452!). San Blas District, Perme, 28 Apr. 1933, G. Cooper III 287 (AMES-02158438!, AMES-02158461!, F-771391! NY!, US-1557502!). Barro Colorado Island. Cana zone. Wheeler Trail, 26 Oct. 1931, O. Shattuck 230 (AMES!). Along the old Las Cruces Trail, between Fort Clayton and Corozal, 31 Dec. 1923, P.C. Standley 29103 (AMES!). COLOMBIA. Córdoba, Buenaventura, $70 \mathrm{~m}$, secondary tropical rain forest, 10 Oct 2016, J.T. Otero 1486 (VALLE!, Fig. 50). Guadeloupe. Monts Caraïbes, Houelmont; forêt semi-décidue, 400 m, 24 Apr. 1979, A. Raynal-Roques 21297 \& J. Jérémie (AMES!). PERU. Huanuco: Prov. Leoncio Prado, tingo maría, 79.59.52 09.17.08, 652 m, 27 Sep. 2010, R. Fernández 3585 (USM!). Pasco: Prov. Oxapampa, Dtto. Pozuzo, $10^{\circ} 4^{\prime} 6.47^{\prime} \mathrm{S}$ 75³3'6.38”O, 1000 m. a.s.1, 25-28 Aug. 1991. D. Bennet, $A$. Bennett \& A. Vargas P. 5256 (MOL!). Junin: Prov. Chanchamayo, La Merced, cascada el tyrol, Mar. 2005, C. Hajeck 2063 (USM!). Localidad desconocida, cultivada en invernadero UCSUR, Lima, A. Damián s.n. (USM!, Fig. 49F). BRAZIL: State of Pará: BR 163, Cuiabá-Santarém Highway; BR 163, Km 1414, Rio Itapacurá, Várzea forest, 24 Nov. 1977, G.T. Prance 25739, A. Henderson, B. Nelson, R. Bahia \& M. Santos (U-1468978!). FRENCH POLYNESIA. Austral Islands; Rimatara; Anapoto, 3 m, 4 Sep. 1934, H. St. John 16884 \& F.R. Fosberg (AMES!). SAMOA. Insel Upolu, 1905, K. u. L. Rechinger 933 (W!). FIJI. Viti Levu. Serua: Hills between Waininggere and Waisese Creeks, between Ngaloa and Wainiyambia, dry forest, 50-100 m, 30 Nov.-23 Dec. 1953, A.C Smith 9633 (AMES!, L!). INDONESIA. Archipel. Ind. Borneo, Res. w. Afd. v. Borneo. Pontianak4 Aug. 1931, Mondi 289 (L-0597916!). [Celebes Island] South
Celebes: Danau Towuti, Timampu, Kec. Nuha, 320 m, 12 Apr. 1984, R. Ram. 163 (L!). [Sulawesi Utara, N. Sulawesi] Im Muskabnuss-Plantugen bei Ayermadidi, $150 \mathrm{~m}, 14 \mathrm{Dec}$. 1914, R. Schlechter 20523 (AMES!). Unknown origin: [without more data] 4 Jan. 1909 (L-4170735!); [without data] (L-4175486!). [without more data] Cult. In Hort. Bog. (U1468932 !).

OTHER SPECIMENS: UNITED STATES OF AMERICA. Florida: Dade Co. growing on trees in an extensive area in Cutler Hammock, on Biscayne Bay, 15 May 1976, D.S. Correll 47216 \& J. Popenoe (NY); Brickell Hammock, Miami, Dade County, J.K. Small s.n., 19 Feb.-22 Mar. 1915 (NY). MEXICO: Unknown locality: "1815 de Mexico, Epidendrum vanilla" [Sessé and Mociño collection] Pavón s.n. (G); "Mexico", Mr. Cowan (G). Chiapas: Nahá, Mpio. de Ocosingo; $27 \mathrm{~km}$ al SE de Palenque por la carretera fronteriza hasta el Crucero Chancalá, después $55.6 \mathrm{~km}$ por el camino de terracería hacia Monte Líbano, $16^{\circ} 56^{\prime}-17^{\circ} 01^{\prime} \mathrm{N}$, 91³3'-91³8' W; 900 m, 6 May 1999, A. Durán Fernández 1166 (MEXU). [Reserva Ecológica "El Ocote", Mpio. Ocozocuautla, 750 m, 14 Feb. 1986, M. Palacios-Ríos 2823 (XAL). Alrededores de la Laguna Ocotalito, cerca de Monte Líbano, 950 m, M. Soto 2836 (AMO-spirit); same locality, M. Soto 2840 (AMO-spirit). Estación de Biología de Chajul, montículo 1, ruinas El Zapote, ca. $1 \mathrm{~km}$ de la estación, $16^{\circ} 08^{\prime}$ N, 9053’ W, 200 m, 20 Jun. 1996. M. Soto 7947 (AMO). Mpio. Ocosingo, Estación de Biología de Chajul, vereda que conecta la vereda a La Granja con la de la Sabana I, a unos $500 \mathrm{~m}$ del Río Lacantúm, ca. $200 \mathrm{~m}, 16^{\circ} 08^{\prime} \mathrm{N}, 90^{\circ} 53^{\prime} \mathrm{O}$, 13 Abr. 1997, M. Soto 8355 (AMO). Estación de Biología de Chajul, junto al Río Lacantun.. montículo 1, Ruinas El Zapote, 15 Abr. 2000, M. Soto 9728, S. Maldonado, L. López \& P. Schluetter (AMO). Selva del Ocote, $\mathrm{km} 44.7$ de la carretera Ocozocuautla-Malpaso, cerca de la presa, $275 \mathrm{~m}$, 21 Abr. 2000, M. Soto 9922, S. Maldonado, P. Schluetter, L. López \& M. Soto (AMO). Palenque, Abr. 1892, 450 m, R.M. Comisión Geográfico-Exploradora, Sección de Historia Natural 7725 (AMES-21309). 6 km al E de Emilio Rabasa, $1 \mathrm{~km}$ al NE de La Reyna, Ocozocuautla, $16^{\circ} 55^{\prime} \mathrm{N}, 93^{\circ} 38^{\prime} 40^{\prime \prime}$ W, 720 m, S. Ochoa 3659 (CHIP). Oaxaca: Cerro Machete, Distr. Pochutla, 800 m, Feb. 1941. B.P. Reko 6279 (AMES60425). 3 km al W de La Esperanza, Mpio. Ixtlán de Juárez, Sierra Norte, E. Morales 1 (AMO-16697). Usila, Mpio. Usila, cultivada en los vainillales de la familia Bautista, cerca de la pista de aterrizaje, 90 m, 25 Abr. 1992, M. Soto 6672 \& M. Hernández (AMO-exssicata, AMO-spirit); same data, $M$. Soto 6673 \& M. Hernández (AMO); same data, M. Soto 6674 \& M. Hernández (AMO). Dto. Tuxtepec, Mpio. San José Independencia, Cerro Clarín, en el extremo SW de la Presa Temascal, ca. 120 m,1 May 1994. M. Soto 7630, U. Guzmán \& Carlos (AMO). Instituto Tecnológico Agropecuario, San Bartolo Tuxtepec, plantación a cargo de Jesús Pérez Meza, Abr. 1996, M Soto 8040 (AMO). Ejido La Gran Lucha, 


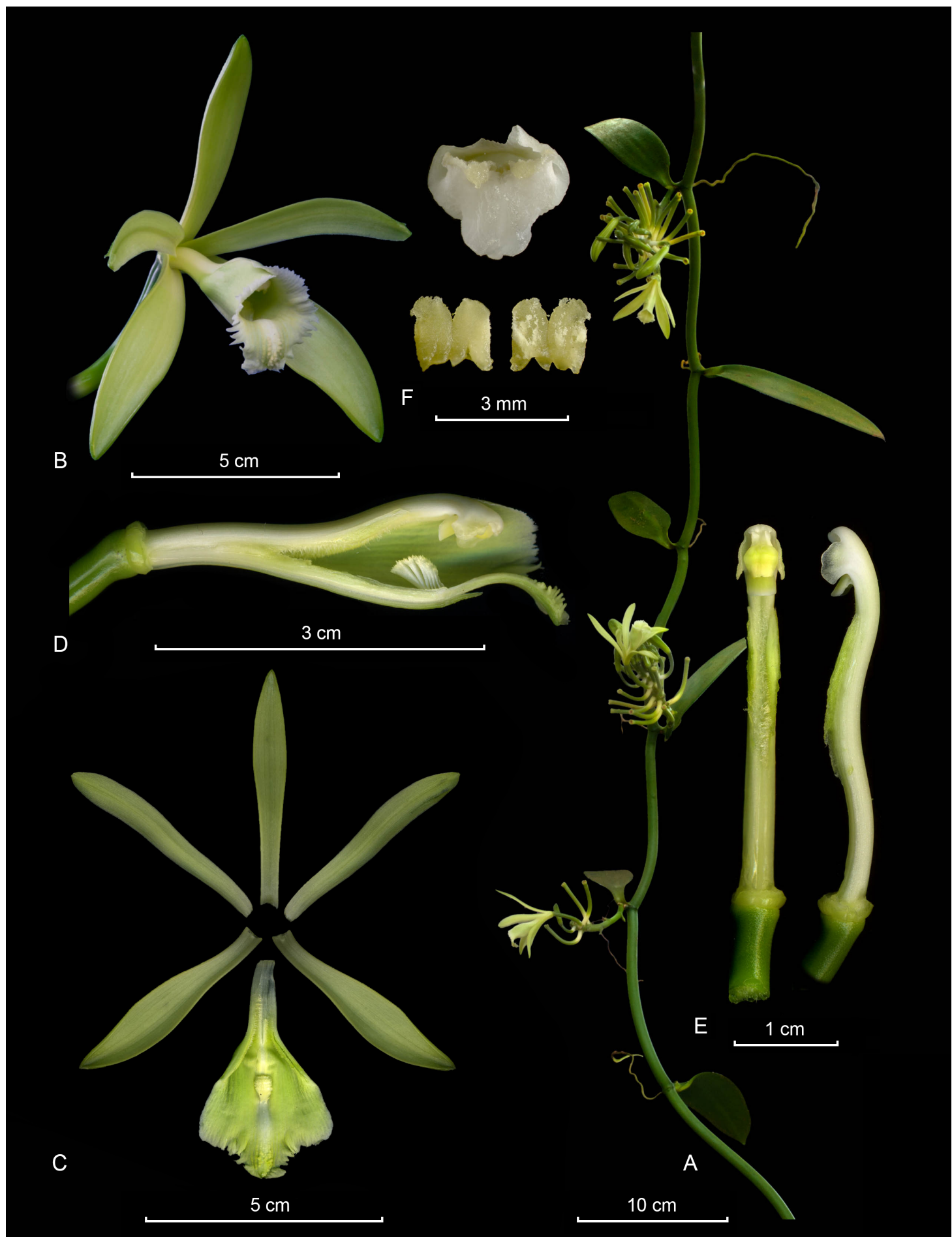

Figure 47. LCDP of Vanilla planifolia. A. Habit. B. Flower. C. Dissected perianth, flattened. D. Lip and column lateral view. E. Column, ventral and lateral view. F. Anther cap and pollinia. By D. Bogarín based on F. Pupulin 8274 (JBL-spirit) from Cahuita, Costa Rica. 


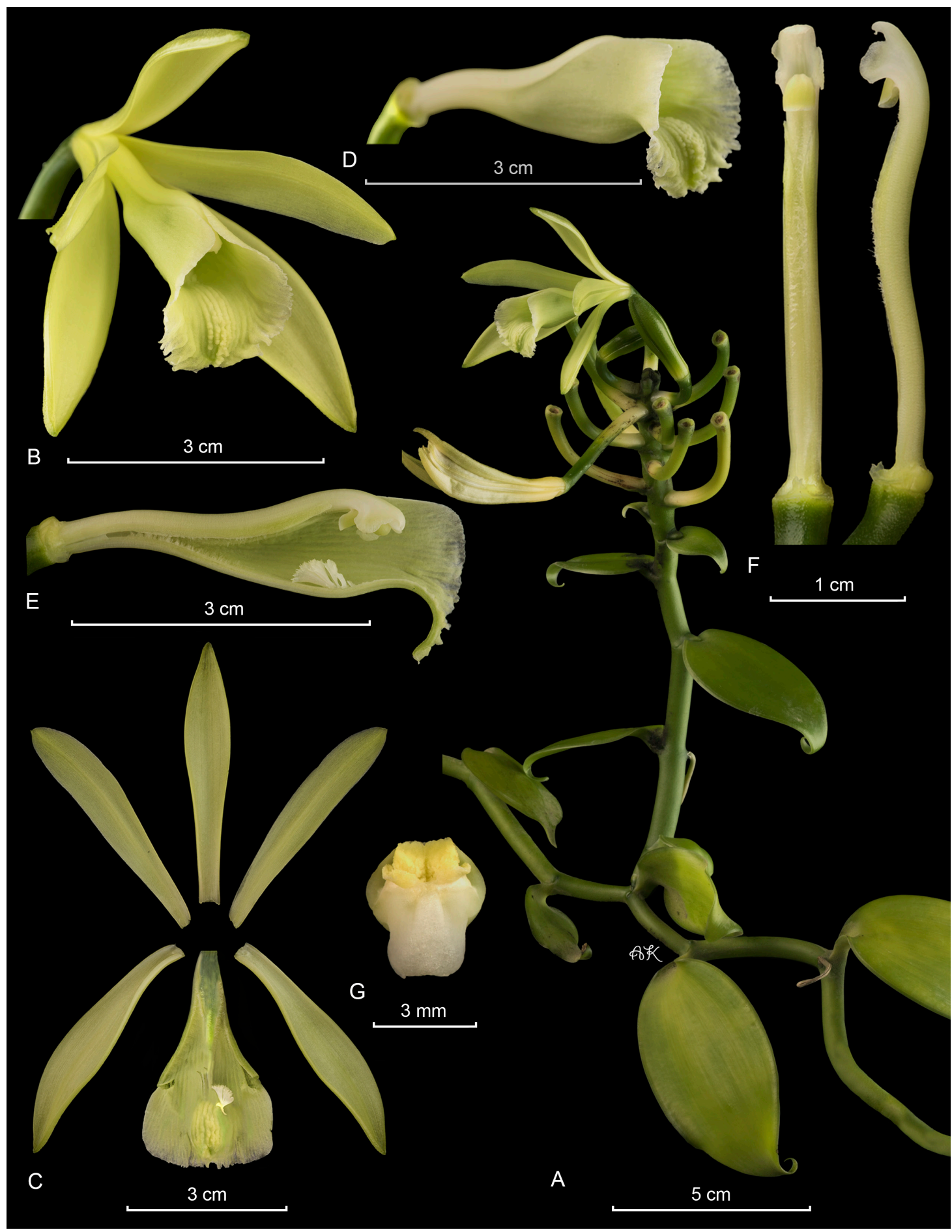

Figure 48. LCDP of Vanilla planifoila. A. Habit. B. Flower. C. Dissected perianth, flattened. D. Lip lateral view. E. Lip and column lateral view. F. Column, ventral and lateral view. G. Anther cap and pollinia. By IC \& APK based on F. Pupulin 8276 (JBL-spirit) from Cahuita, Costa Rica. 


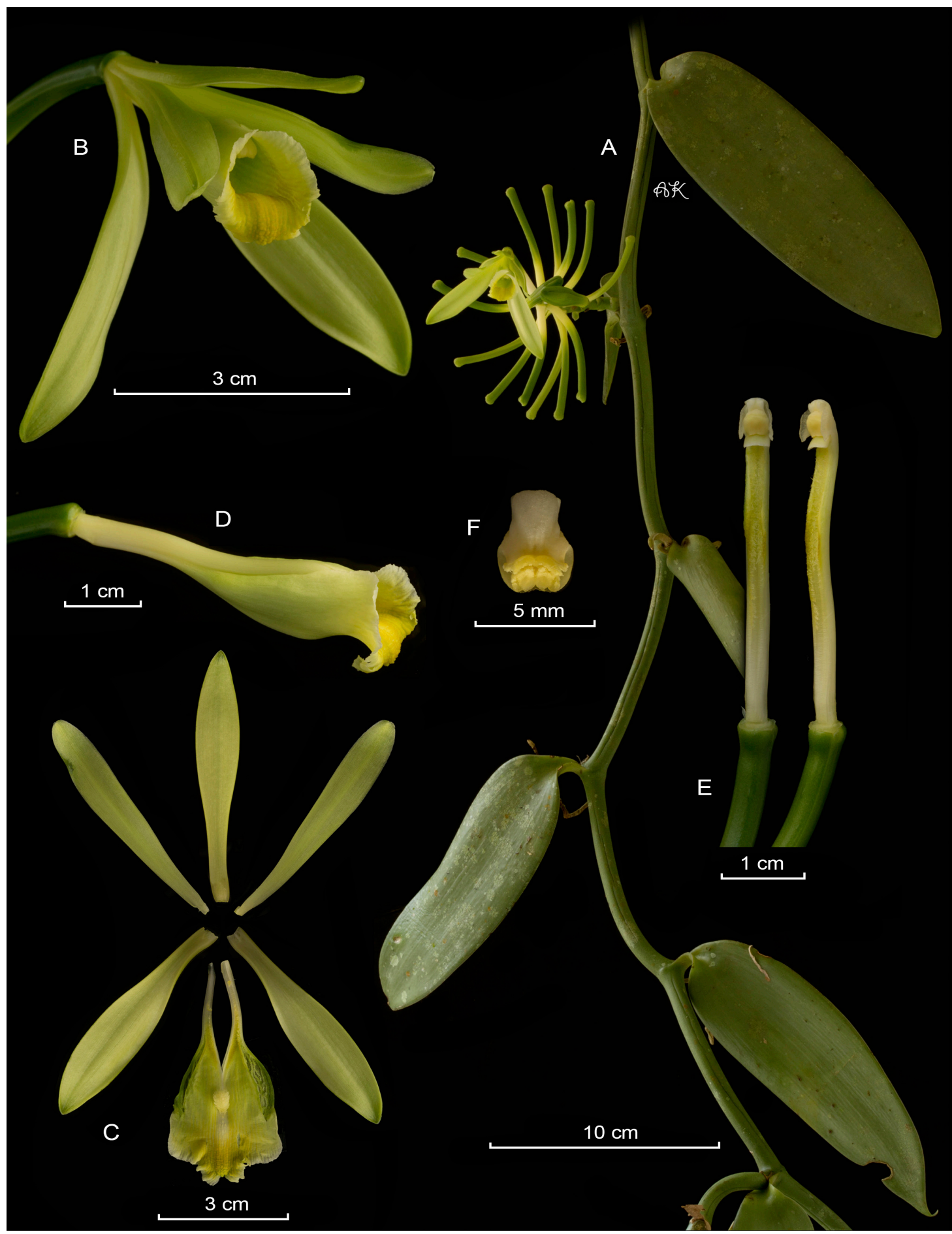

Figure 49. LCDP of Vanilla planifoila. A. Habit. B. Flower. C. Dissected perianth, flattened. D. Lip and column lateral view. E. Column, ventral and lateral view. F. Anther cap and pollinia. By APK based on A.P. Karremans 7042 (JBL-spirit), cultivated at La Tirimbina, Costa Rica. 


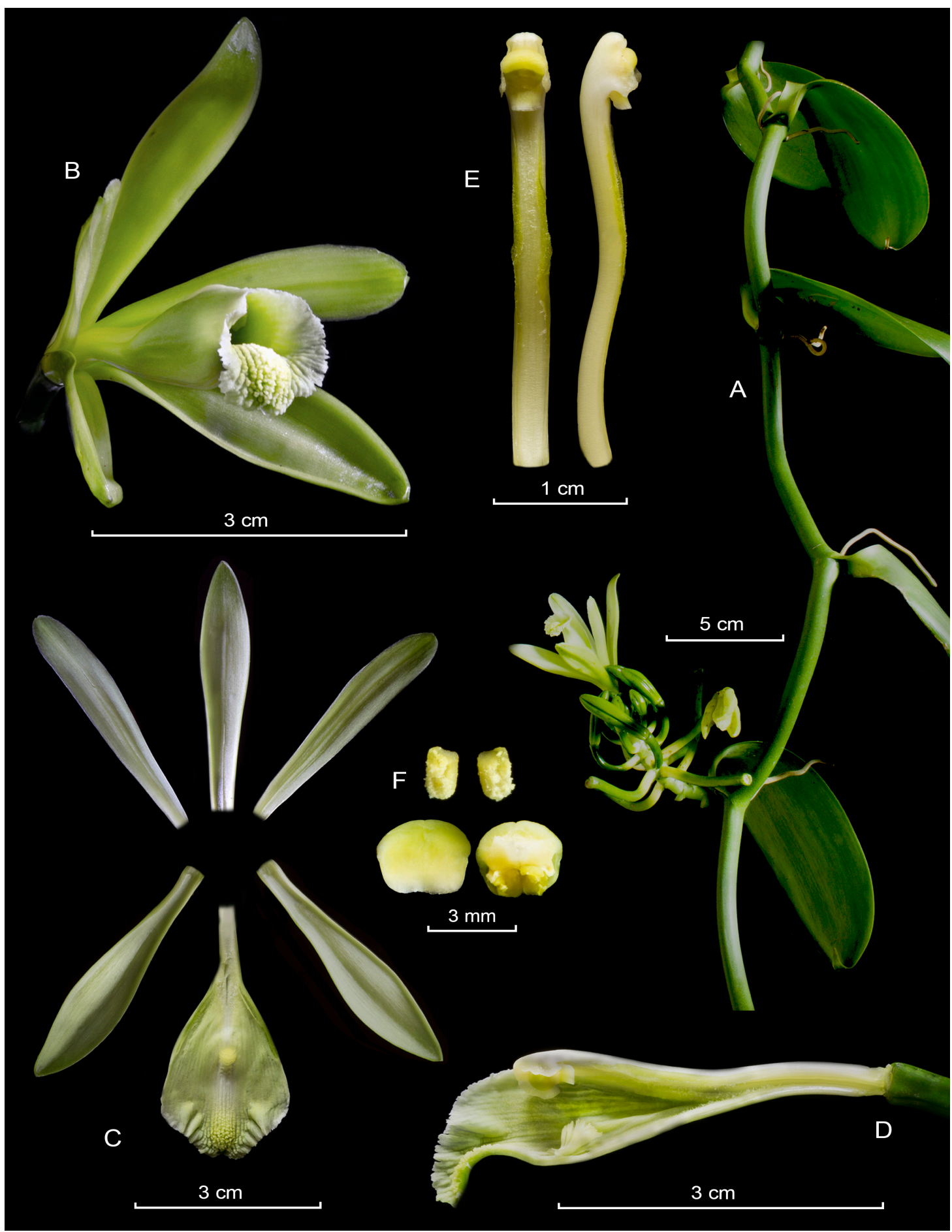

Figure 50. LCDP of Vanilla planifoila. A. Habit. B. Flower. C. Dissected perianth, flattened. D. Lip and column lateral view. E. Column, ventral and lateral view. F Anther cap and pollinia. By Y. Alomía \& J.T. Otero based on Otero 1486 (VALLE) from Colombia. 
Mpio. Valle Nacional. Vainillal particular de Nemesio Miguel Martínez. Plantación a 200 m, 17 Mar. 1997, M. Soto 8117 \& A. Cibrián (AMO). La Cueva, cerca de Cerro Verde, $\mathrm{km}$ 25.3 del camino Jalapa de Díaz-Usila, Oaxaca. Plantación de vainilla de José Roldán, 780 m, ca. $18^{\circ} 57^{\prime} \mathrm{N}, 94^{\circ} 44^{\prime} \mathrm{W}$, 21 Abr. 1997, M. Soto 8483 \& M. Hernández (AMO). 3 km al W de La Esperanza, Mpio. Ixtlán de Juárez, Sierra Norte, R. López G. 2 (AMO-16698). Cultivada en los vainillales de Santiago Tlatepuzco, Mpio. Usila, ca. $500 \mathrm{~m}$, R. Medinilla s.n. (AMO-spirit). Between Los Llanos de Ozumazin and Río Chiquito, District of Choapam. Lat. 17³5', Long. 9555', 700 ft. [213 m], 1 May 1939, R.E. Schultes 727 \& B.P. Reko (AMES-9034). Mun. Santa María Jacatepec, predio El Aguila, al O de San Agustín, entrando por la Reforma, $28 \mathrm{~km}$ SO de Tuxtepec, carr. a Matías Romero. $17^{\circ} 50^{\prime}$ N, 9606' W. 550 m, 19 Ene. 1988, R. Torres 11027 \& E. Martínez (AMO, MEXU). Puebla: Yancuictlalpan, Cuetzalan, F. Basurto 263 \& R. Patrón (MEXU). Quintana Roo: Isle of Cozumel, Cenote Cedral, $20^{\circ} 21^{\prime} \mathrm{N}, 86^{\circ} 59^{\prime} \mathrm{W}$, 5-10 m, 2 Sep. 1935, O. Nagel 5001 \& E. Oestlund (AMES51852). Ejido Hermenegildo Galeana, predios de Artemio y Constantino López Pascual, 18¹0'33.2" N, 89¹5'08.4" W, 10 May 2008. M. Soto 11370, L. Ibarra \& C. López (AMO). San Luis Potosí: Tanjasnec, Mpio. San Antonio, planted, 4 May 1979, J.B. Alcorn 3006 (LL, MEXU). Tabasco: Teapa, $0.34 \mathrm{~km}$ al E de la Universidad Agraria de Chapingo, 17³1'31" N, 9255'33" W, 28 Ene. 2002, J. Calónico 21157 et al. (MEXU). Poblado de Nacajuca, 20 m, 3 Oct. 1978, R. Ortega 858, W. Márquez \& B. Guerrero (XAL). Veracruz: [Cultivated] Predio Escolín, $12 \mathrm{~km}$ al NE de Papantla, 370 m, 22 Jun. 1987, A. García 3226 (MEXU). [Cultivated] Papantla de Olarte, $20^{\circ} 27^{\prime}$ N, 97¹9' W, F. Rosas C.I.P. 709 (XAL). Estación de Biología Tropical de Los Tuxtlas, ca. 200 m, G.A. Salazar 2247 (AMO-drawing, AMO-exsiccata, AMO-spirit). Volcano San Martín, 5 May 1936, 18³5' N, 95¹1' W, 600 m, J. González 5790 \& E. Oestlund 5790 (AMES-51851). San Andrés Tuxtla, El Vigía, al E de Cerro Blanco, 28 May 1967, M. Peña 108 (AMES-11744). Vainillal del Sr. Rafael Cardeña, Díaz Mirón y Río Nautla, Papantla, 180 m, 31 Mar. 1995. M. Soto 7648 (AMO). Mpio. Atoyac, a un lado de la vía del tren, cerca del puente, 2 May 1995, ca. 400 m, $M$. Soto 7745 (AMO). [Cultivated] Papantla, 17 Feb. 1985, P. Reyes s.n., N. Carcamo \& N. Garcilazo (XAL). Rancho El Coscolín, El Escolín, Cerro Grande, Mpio. Papantla de Olarte, plantación de vainilla, $350 \mathrm{~m}, 20^{\circ} 29^{\prime} \mathrm{N}, 9^{\circ} 33^{\prime} \mathrm{W}, 25 \mathrm{Abr}$. 1989, R. Castillo M. 210 \& H. Cálix de Dios (AMO, MEXU678228). Rancho El Coscolín, El Escolín, Cerro Grande, Mpio. Papantla de Olarte, 20²9' N, 97³3' W, 350 m., 25 Abr. 1989, R. Castillo M 211 \& H. Cálix de Dios (AMO, MEXU-678227). A $800 \mathrm{~m}$ al norte de la casa de Genaro, ejido Vista Hermosa, Mpio. Tezonapa, $18^{\circ} 40^{\prime} \mathrm{N}, 96^{\circ} 40^{\prime}$ W, 500 m, 4 Ago. 1986, R. Robles G. 977 (XAL). Yucatan. Cenote de Mayana, Yucatán, 1866, A. Schott 215 (F-276993).
[Unknown locality] 4 Jun. 1899, G.F. Gaumer s.n. \& Sons. (F). In virgin xerophytic forest, forests of Xbac, Apr. 1916, G.F. Gaumer \& Sons 23352 (AMES-71360, AMES-71369, F-446854, MO-948146, NY). Virgin forest near Chemax, on tree trunks, $20^{\circ} 39^{\prime} \mathrm{N}, 87^{\circ} 56^{\prime} \mathrm{W}, 30 \mathrm{~m}$, 29 Sep. 1935 , O. Nagel $5050 \&$ E. Oestlund (AMES-51846). BELIZE: Toledo. In cohune ridge, Bolo Camp, uper reach of Golden Stream, 12 Apr. 1944, P.H. Gentle 4521 (LL). In cohune ridge, near Jacinto Hills, 30 Dec. 1944, P.H. Gentle 5106 (LL). Feeders Road, 14 Miles, San Antonio-Punta Gorda Road, 20 Apr. 1949, P.H. Gentle 6721 (F-1599303, LL, NY). On hill slope beyond San Antonio, 30 Jan. 1952, P.H. Gentle 7557 (MEXU511464, LL). GUATEMALA: Alta Verapaz. Vicinity of Finca Yalpemech, near Alta Verapaz-Petén boundary line, 100-120 m, 24 Mar. 1942, J.A. Steyermark 45286 (AMES-62981, F-1195546). Baja Verapaz: Am Rio Polochic über Tucurú, 900 m, 30. Apr. 1882. F.C. Lehmann 1436 (G). Izabal: Vicinity of Puerto Barrios, at sea level, 2-6 Jun. 1922, P.C. Standley 25064 (AMES-22674). HONDURAS: Atlantida. Lancetilla Valley, near Tela, altitude 20 to $600 \mathrm{~m}, 6$ Dec. 1927-20 Mar. 1928, P.C. Standley 55583 (AMES-36947, F-581081). Comayagua: [Unknown locality] 1300 m, 31 Mar. 1963, A. Molina 11777A (F-1620024). Morazan: [Cultivated] campus of EAP El Zamorano, 800 m, 28 Mar. 1990, A. Molina 34346 (MO-4248893). EL SALVADOR: Finca Las Canoas, 700 m, 11 Apr. 1969, H.C. Clason 268 \& F. Hamer MO-3092269); same locality, near Ahuachapan, 9 Apr. 1978, H.C. Clason 776 \& F. Hamer (SEL-049262). PANAMÁ: Province of Colón: Between France Field, Canal Zone, and Catival, 9 Jan. 1924, P.C. Standley 30160 (US-1225400). Barro Colorado Island in Gatún Lake, $120 \mathrm{~m}$ or less, 18-24 Nov. 1925, P.C. Standley 40897 (US-1251676). Barro Colorado Island, Lutz Trail 300, 10 Jul. 1970, T.B. Croat 11177 (SCZ-2261). NIUE: Skypes 150572 (CHR); Yuncker 9856 (CHR) (Cribb \& Whistler 2011).

Distribution: Native to Mexico, Guatemala, Belize, Honduras, El Salvador, Nicaragua, Costa Rica and Panama, perhaps naturalized in Colombia, Peru, Brazil, and the Lesser Antilles (Fig. 55A). Widely cultivated around the tropical areas of the world, including Florida and Hawaii (U.S.A.), French Polynesia, Cook Islands, Samoa, Niue, Tonga, Fiji (Oceania), Papua New Guinea, Indonesia and India (Asia), Democratic Republic of the Congo (Africa), among others.

EXTENT OF OCCURRENCE: $18,465,274.534 \mathrm{~km}^{2}$.

The name Myrobroma fragrans Salisb. (1807) is traditionally cited as a synonym of $V$. planifolia (Rolfe 1896, Garay \& Sweet 1974, Garay 1978, Soto Arenas \& Cribb 2010, Soto Arenas \& Dressler 2010). This is because the illustration accompanying the description 


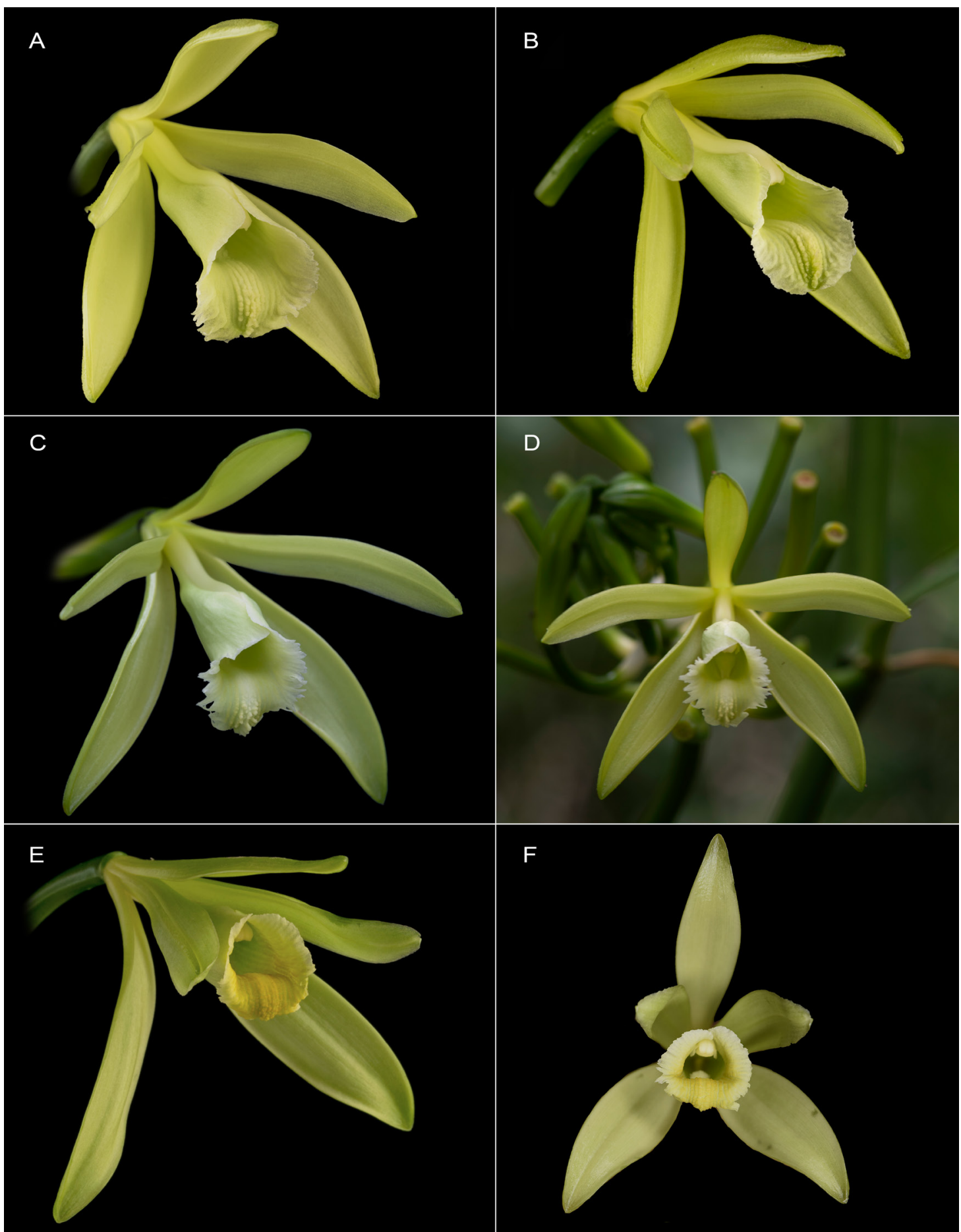

FIgure 51. Vanilla planifolia different flowering specimens showing common morphological variations. A. Costa Rica, Cahuita National Park, Pupulin 8276. B-D. Costa Rica, Cahuita National Park, Pupulin 8274. E. Costa Rica, cultivated at La Tirimbina, Karremans 7042. F. Peru, cultivated in Lima, A. Damián s.n. Photographs by APK (A, B, E), AD (F) and F. Pupulin (C, D). 
of M. fragrans (Fig. 52) not only is the same species as V. planifolia but is in fact based on the same specimen flowered in the collection of Charles Greville (Fig. 43). However, M. fragrans is a superfluous, and therefore illegitimate, name because it cites Epidendrum rubrum Lam. as a synonym and definitively includes the type. The name Vanilla fragrans (Salisb.) Ames was proposed as a new combination for Myrobroma fragrans. As the latter is illegitimate, Vanilla fragrans Ames must be regarded as a nomen novum rather than a new combination. However, it definitively includes the types of both Epidendrum rubrum and Vanilla planifolia, and is therefore also in itself illegitimate.

The type of E. rubrum is Plumier's unpublished illustration MSS. 3. t. 100 which bears the name "Vanilla flore albo, fructu breviore coralino". After inspection of the original text and illustration kept at the MNHN in Paris we definitively exclude Epidendrum rubrum, and its nomenclatural synonyms Myrobroma fragrans and Vanilla fragrans, from the synonymy of Vanilla planifolia. The material illustrated and described by Plumier has thick stems with small, narrow leaves, a violet, undulate lip and a short red fruit. It corresponds better to the Antillean Vanilla claviculata Sw. as inferred by Ackerman (2014), or Vanilla poitaei Rchb.f. as Garay \& Sweet (1974) suspected. Preliminarily we agree with the latter; if confirmed the name Vanilla rubra (Lam.) Urban would have priority over V. poitaei and should be reinstated.

When proposing his Vanilla viridiflora, Blume provided only a short description and no illustration. However, he made it clear that his Javan specimen came from a cultivated plant of American origin. The origin of this material was traced by Prof. Charles Morren as being the same as that cultivated by Greville (Rolfe 1896), and which served as type of $V$. planifolia. The name was not treated under V. planifolia by Soto Arenas \& Dressler (2010), but was included as a synonym in Soto Arenas \& Cribb (2010). The taxon is here lectotypified with a specimen that was located at $\mathrm{L}$, and which indeed corresponds well with $V$. planifolia.

Even though mostly associated with Vanilla planifolia, the identity of $V$. sativa and $V$. sylvestris, published by Schiede in 1829, remained obscure given they were mainly known on the basis of their original descriptions (Rolfe 1895). Soto Arenas \& Dressler
(2010) indicate that a single leaf representing $V$. sativa was located at $\mathrm{BM}$, while type material of $V$. sylvestris was not located. Indeed a specimen consisting of a single leaf was located at BM, but we were also able to find material of both these cryptic taxa at HAL. Even though the material is still relatively poor, these taxa can now be reassessed on the basis of these specimens. Based on the shape of the leaf and the original descriptions it seems quite plausible that these taxa indeed represent variations of Vanilla planifolia.

Vanilla schwackeana is another obscure name in the genus. Virtually unused, it was proposed by Hoehne (1944) on the basis of a specimen composed of a sterile plant bearing five leaves and two loose flowers, of which the author himself suspected could be a mixture of unrelated elements. Soto Arenas \& Cribb (2010) recognized the species but agreed it could represent a mixture of parts of different species. We find that the dissected flower is congruent with Vanilla planifolia, sharing the distinctive trilobate, denticulate lip with an apical verrucose callus. The thin acuminate leaves are unusual for the species and may indeed belong to a different species. The dissected flower is therefore selected as lectotype here to clarify the identity of this taxon.

Vanilla sotoarenasii was recently proposed as a new species despite evidence provided in the publication that it is genetically indistinguishable from Vanilla planifolia accessions (Azofeifa-Bolaños et al. 2017). The taxon, based on material from the Caribbean coast of Costa Rica, was said to differ from $V$. planifolia morphologically and chemically. However, despite the availability of large populations at the type locality of this taxon, the authors measured morphological and chemical only in handful of clones "cultivated in controlled conditions in BRC Vatel in La Réunion". This poses a significant methodological bias as it definitively excludes the possibility of assessing the natural variation of these traits within a population, not to mention the whole distribution of the taxon. An assessment of the population at the type locality of $V$. sotoarenasii proves that morphological features used to distinguish this taxon, such as leaf and fruit color, shape and size, are extremely variable even within a single plant (Fig. 47, 48, 51, 53, 54); and impossible to separate consistently from the variation observed in $V$. planifolia. Furthermore, specimens from the type 


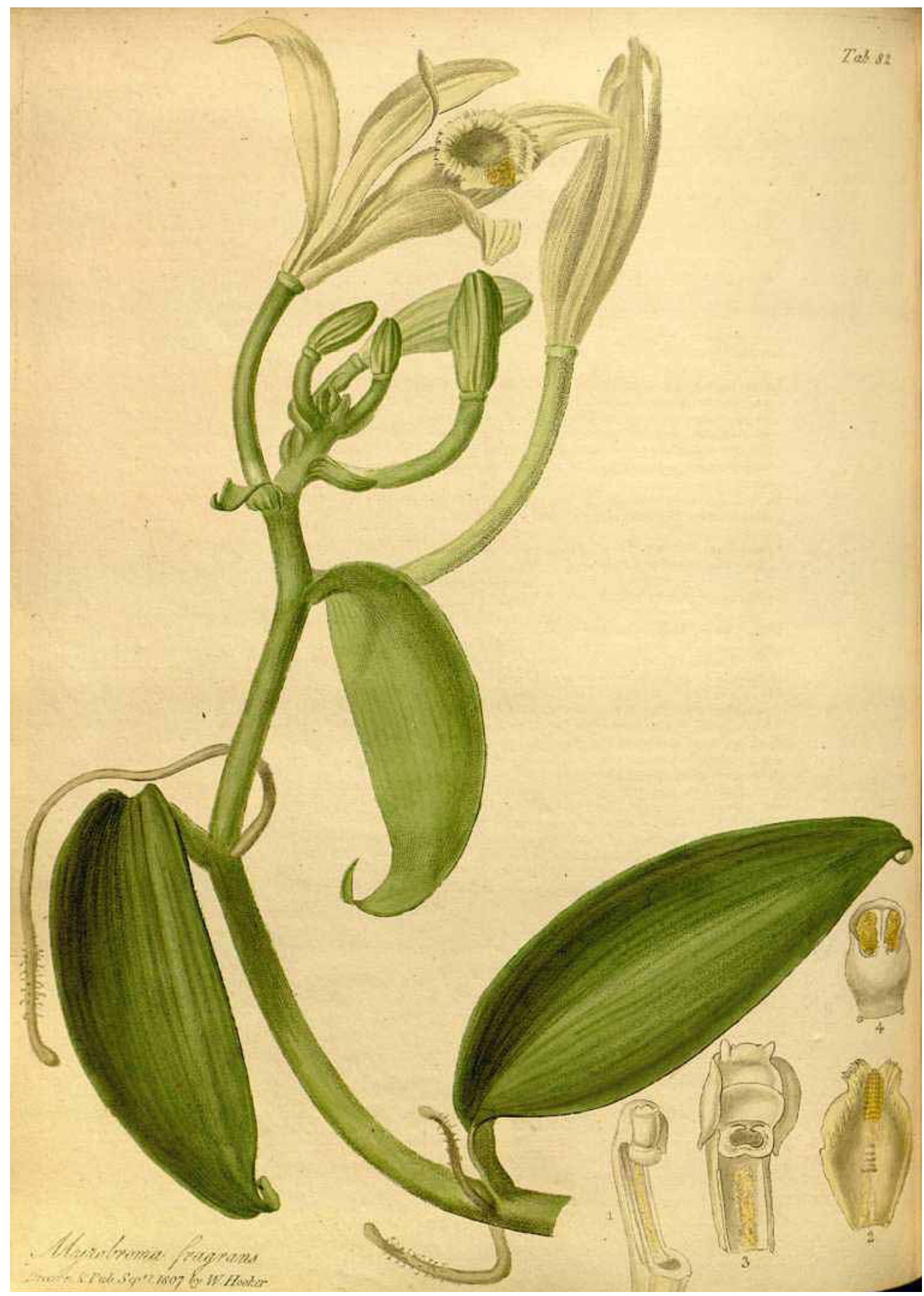

FIGURE 52. Vanilla planifolia, illustration based on a specimen from Charles Greville that accompanies the original description of Myrobroma fragrans. 

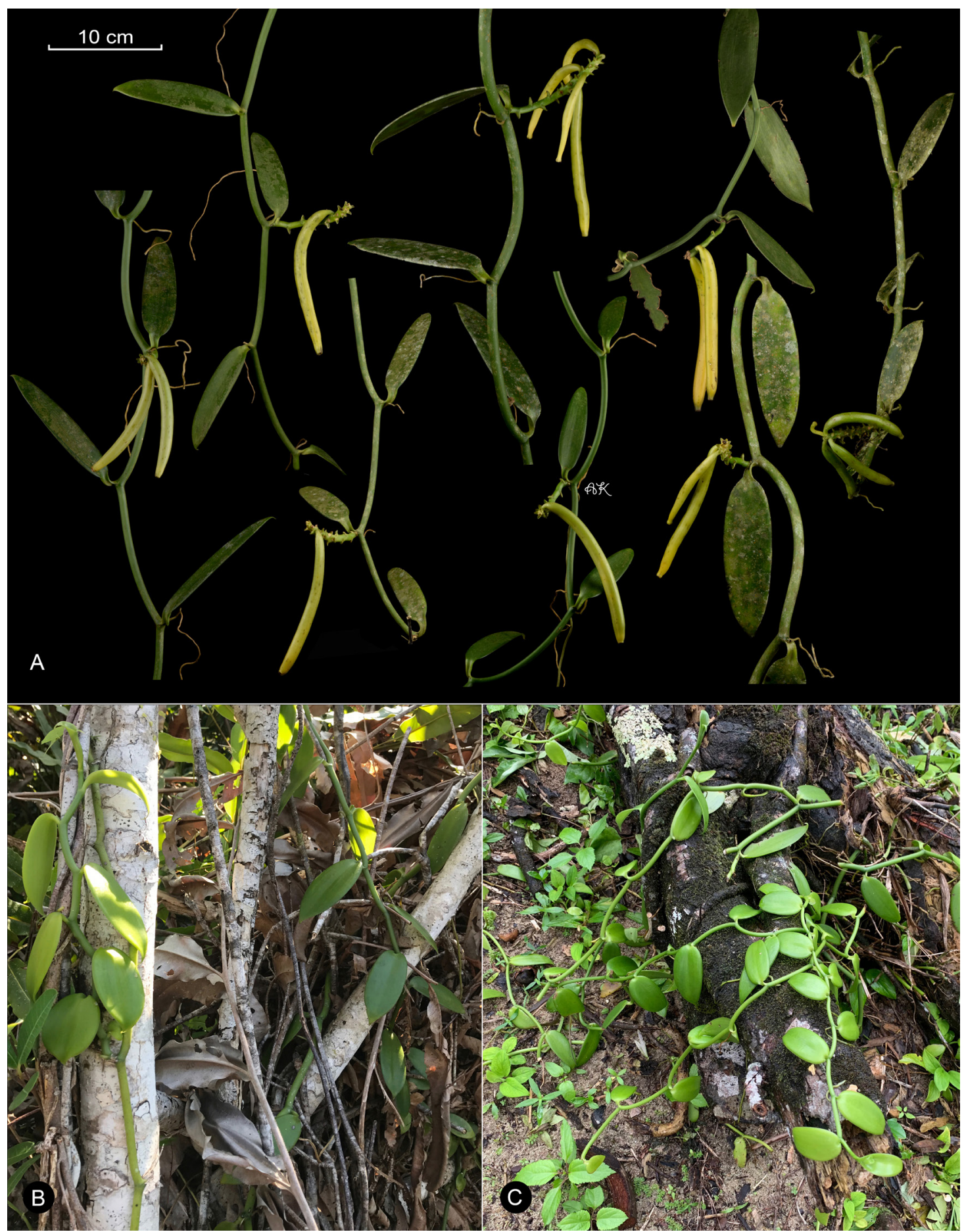

FIgURE 53. Vanilla planifolia wild plants. A. Stem, leaf and fruit disposition and morphological variation within and between individuals of a single population in Cahuita, Costa Rica. B. Plants at Cahuita National Park growing closer to the beach, in exposed areas, are more compact. C. An individual growing on the sand a few steps from the ocean, Bocas del Toro, Panama. Photographs by APK 


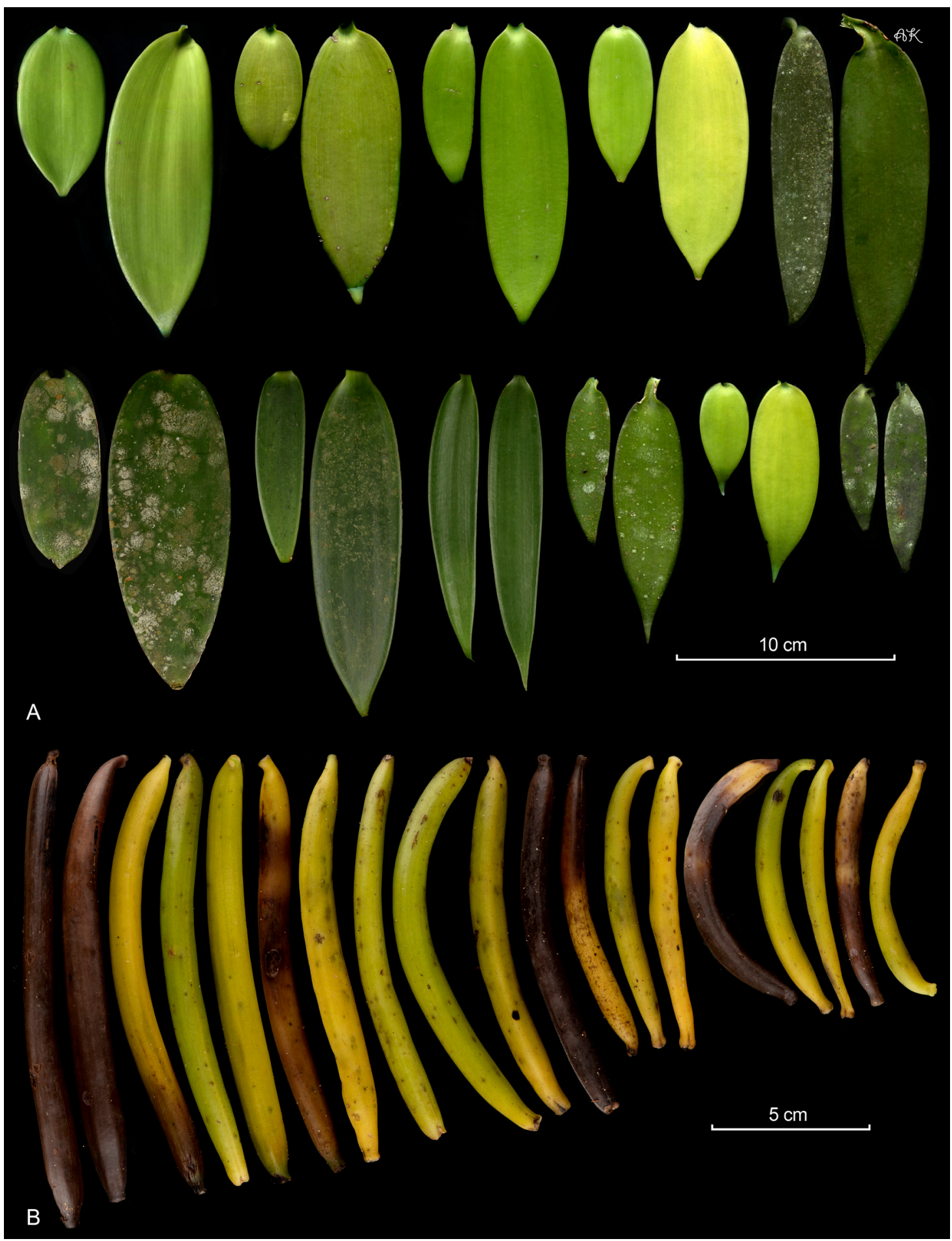

FIGURE 54. Variation within a single population of Vanilla planifolia at Cahuita National Park in Costa Rica. A. Diverse leaf pairs taken from single stems showing the within and among individuals' variation in color, shape and size. B. Fruits showing different levels of maturity, color, length, thickness and shape. Photographs by APK. 


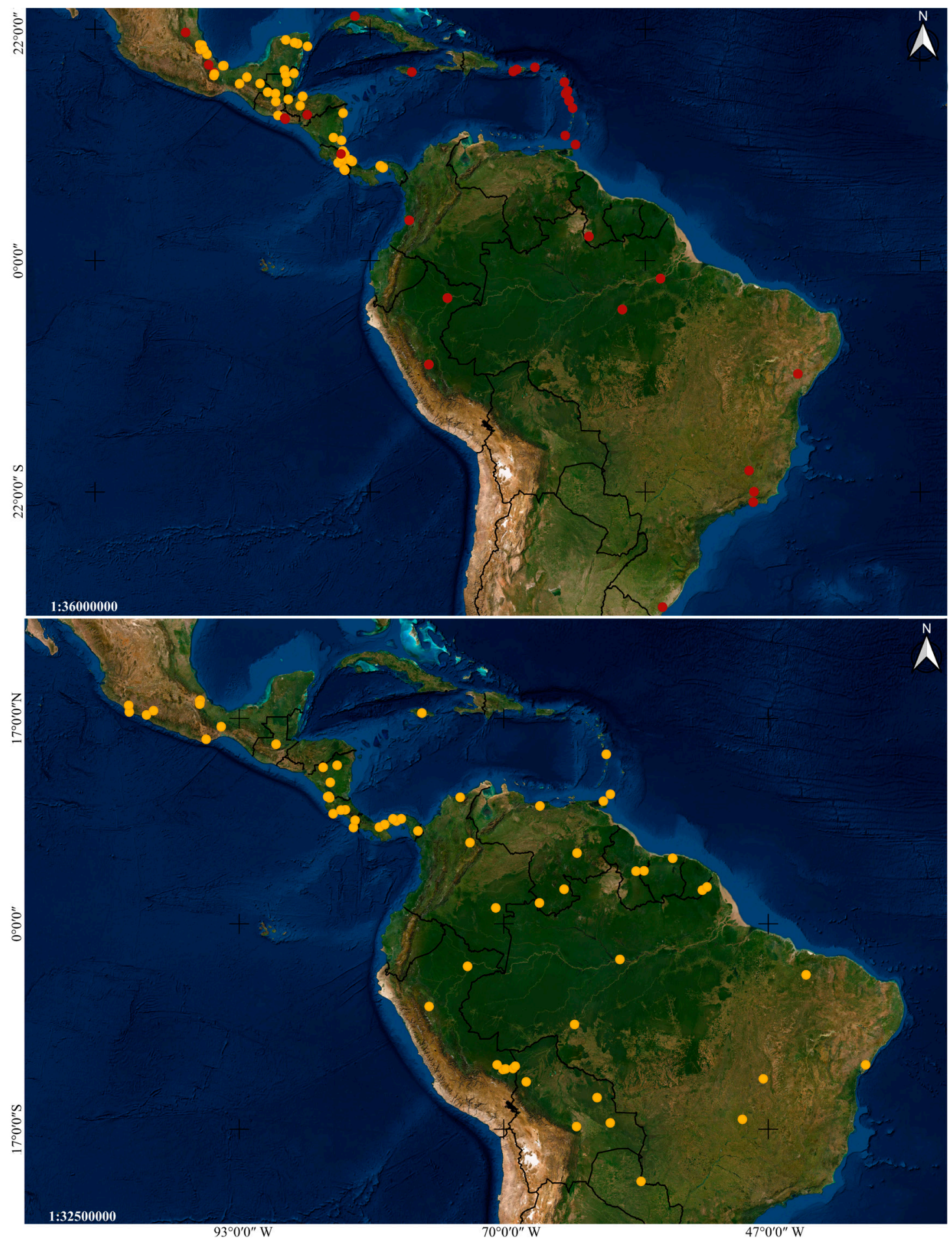

FIgURE 55. Distribution maps of Vanilla species based on studied specimens. A. Vanilla planfiolia Andrews. B. Vanilla pompona Schiede. Images by IC. 
locality of $V$. sotoarenasii are much more similar to the illustrations based on the material that served as type of $V$. planifolia (Fig. 43, 52), then most cultivated cultivars (Fig. 49).

It remains to be proven if these Vanilla populations were introduced to the areas were they are found today. A specimen of this species collected in 1945 in Portete, near Puerto Limón and kept at CR may give some historical context of their cultivation on the Costa Rican Caribbean. The handwritten label on the herbarium specimen (Quirós \& Sáenz 4254) reads: "cocimiento de sus hojas para curar la diabetes" (cooked leaves used to cure diabetes). This suggests these plants have been present in the Caribbean coast of Costa Rica for at least seventy-five years, and that they were being used and cultivated by locals. The first people to settle Cahuita did so in 1828. It is known that they cultivated yams, cassava, cocoa and coconut, and sailed between Limon, Cahuita and the Bocas del Toro area southward in Panama, as well as northwards to the coast of Nicaragua (Weitzner \& Fonseca Borrás 2001). The Parque Nacional Cahuita was created in 1978, and the presence of coconut, cocoa trees and oil palms within its regenerated forest are proof of its agricultural past (Weitzner \& Fonseca Borrás 2001). It is unclear if these Vanilla plants are associated solely with human settlement, but it is clear that they are found in the same area were the afro-Caribbean communities of Nicaragua, Costa Rica and Panama live and have long interacted. In Bocas del Toro, the local afro-descendant population uses vanilla to spice up one of their more traditional dishes, the oatmeal porridge (APK pers. obs. 2019).

The unusual morphological plasticity found in the population at the type locality of $V$. sotoarenasii, especially of the leaf color, size and shape and of the lip ornation may be indicative of a certain degree of hybridization, perhaps backcrosses between $V$. planifolia and $V$. odorata or $V$. $\times$ tahitensis. Although the $V$. planifolia genes are clearly dominant in the population, as is reflected by the phylogenetic studies (Azofeifa-Bolaños et al. 2017; Chambers et al. in prep.), odd morphological features occasionally express, including very narrow leaves, fimbriae on the lip and indehiscent fruits; all features found in $V$. $\times$ tahitensis. Further population studies are certainly needed to fully understand this taxon.

The names Vanilla tiarei Costantin \& Bois, nom. nud., and Vanilla hirsuta M.A.Clem. \& D.LJones are excluded from the synonymy of $V$. planifolia and placed under the cultivated hybrid Vanilla $\times$ tahitensis J.W.Moore. The name Vanilla duckei Huber has been placed under $V$. planifolia, but we agree with Koch et al. (2013) that they are not conspecific.

10. Vanilla pompona Schiede, Linnaea 4: 573. 1829. Fig. 55B, 56-63.

TYPE: [MEXICO]. "Baynilla pompona HispanoMexicanorum. Hab. Papantlae et Colipae." Schiede s.n. (lectotype designated here: W-ESP70151!, Fig. 56; isolectotypes: HAL-111283! Fig. 57A, HAL-111284!, Fig. 57B, HAL-111285!, Fig. 57C, BM-000062775!, LE-00006464!).

Syn.: Vanilla grandiflora Lindl., Gen. Sp. Orchid. Pl. 435. 1840.

Vanilla pompona subsp. grandiflora (Lindl.) Soto Arenas, Lankesteriana 9: 340. 2010.

TYPE: FRENCH GUAYANA. Martin s.n. (holotype: K-L!, Fig. 58).

Syn.: Vanilla hamata Klotzsch, Bot. Zeitung (Berlin) 4: 563. 1846, syn. nov.

TYPE: PERU. Ruiz (holotype, B, destroyed). Neotype (designated here): PERU. Ruiz (F-18349!, holotype photo, Fig. 59A; isoneotype, AMES38629 !, copy of the holotype photo, Fig. 59B).

Epitype (designated here): PERU. Chicoplaya, Flora Peruviana et Chilensis, illustration by J.G. Rivera N. 341 [reproduced as figure 52C in Pupulin (2012); Fig. 60A].

Syn.: Vanilla lutescens Moq. ex Dupuis, Rev. Hort. (Paris), sér. 4, 5: 121. 1856.

TYPE: [VENEZUELA]. Communiquée par $\mathrm{M}$. Coudert, horitculteur distingué de Bordeaux. Elle est originaire du Guayra (La Guaira, Venezuela). [holotype, not found; lectotype designated here: illustration of type reproduced by Dupuis (1856) in Revue Horticole (Paris), Fig. 61A].

Syn.: Vanilla reichenbachii Endrés, nom. nud. in sched., syn. nov.

RIGHT, Figure 56. Vanilla pompona Schiede, lectotype based on Schiede s.n. from Mexico (W-ESP70151). Photographed by APK. 


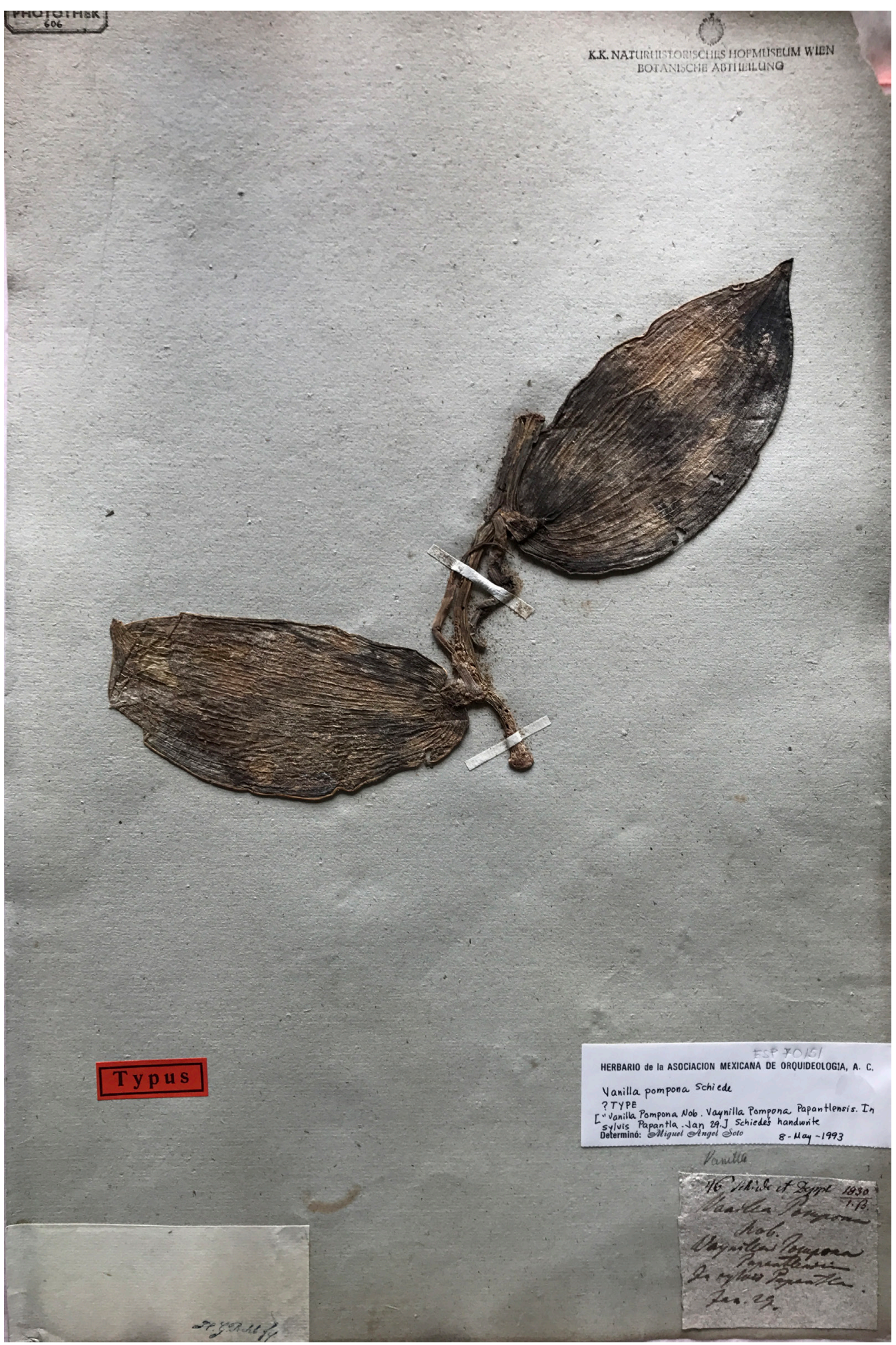




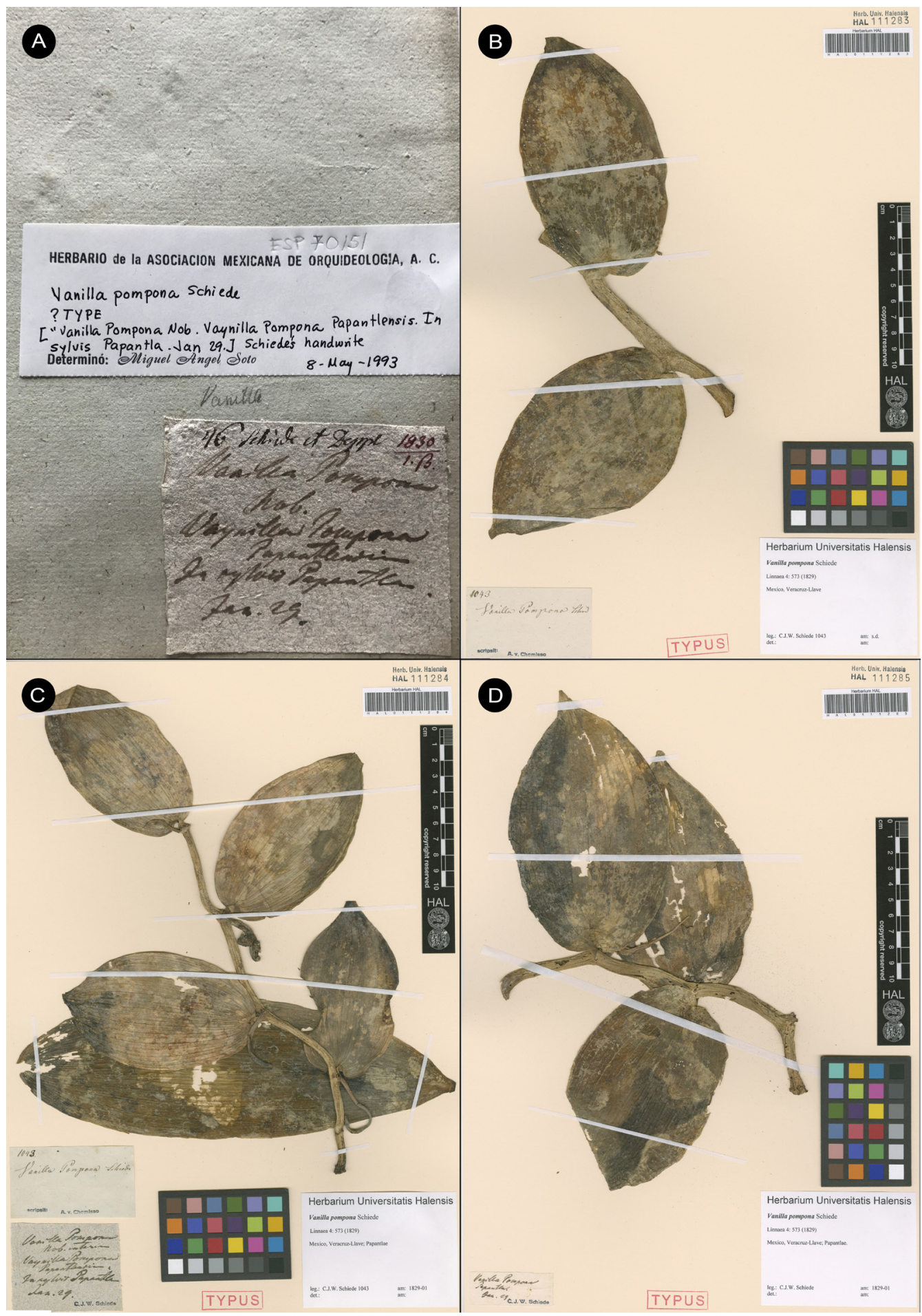

Figure 57. Vanilla pompona Schiede. A. Detail of the lectotype (W-ESP70151), showing the handwritten label by Schiede. B. Isolectotype (HAL-111283). C. Isolectotype (HAL-111284). D. Isolectotype (HAL-111285). B-D @ copyright of the Martin-Luther-Universität, Halle. 


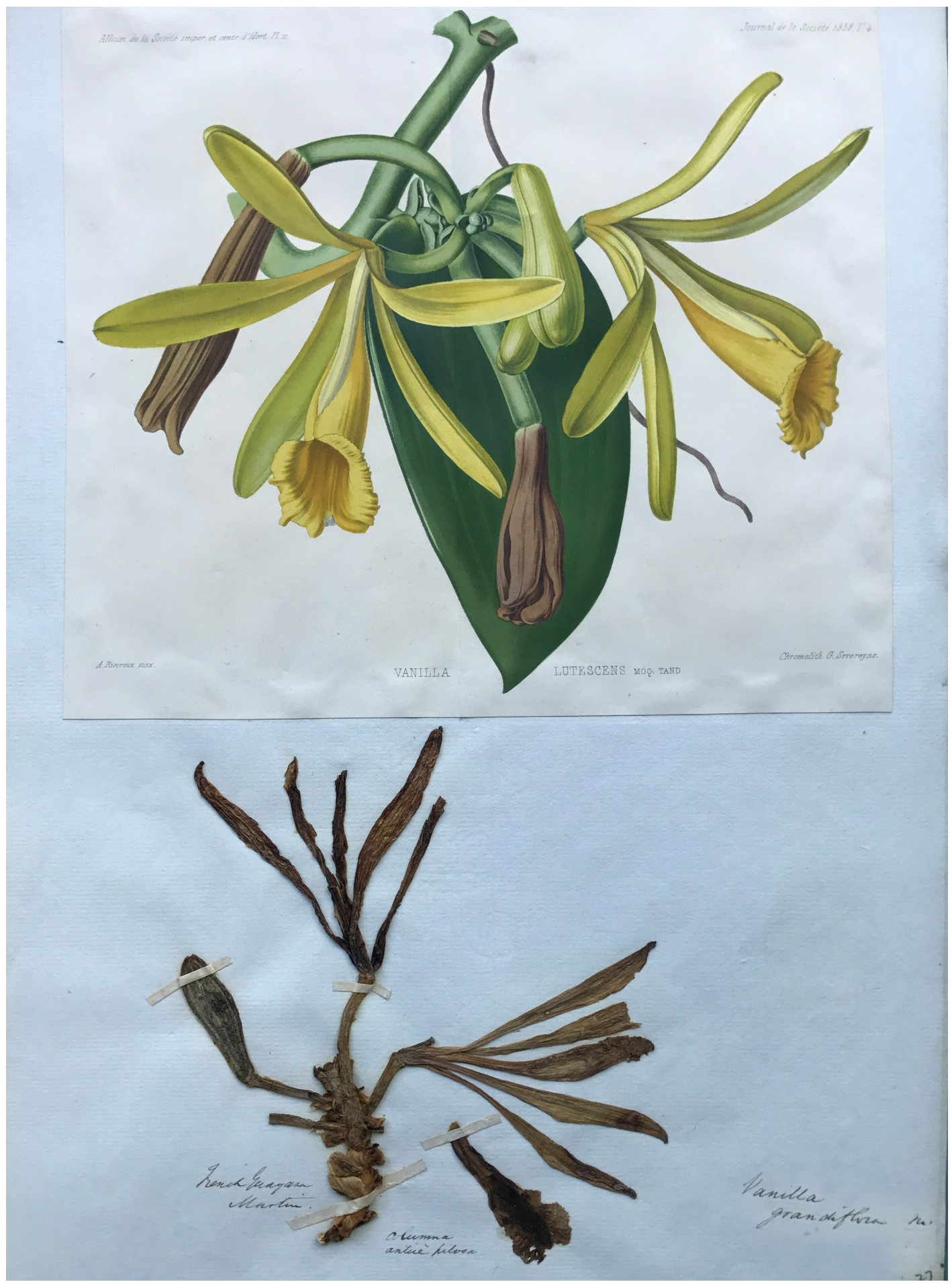

FIGURE 58. Vanilla pompona holotype of $V$. grandiflora, based on Martin s.n. from the French Guiana (K). The illustration by Riocreux from the type specimen of $V$. lutescens exposed at l'Exposition Universelle de Paris has been added above the specimen. Photographs by APK. 


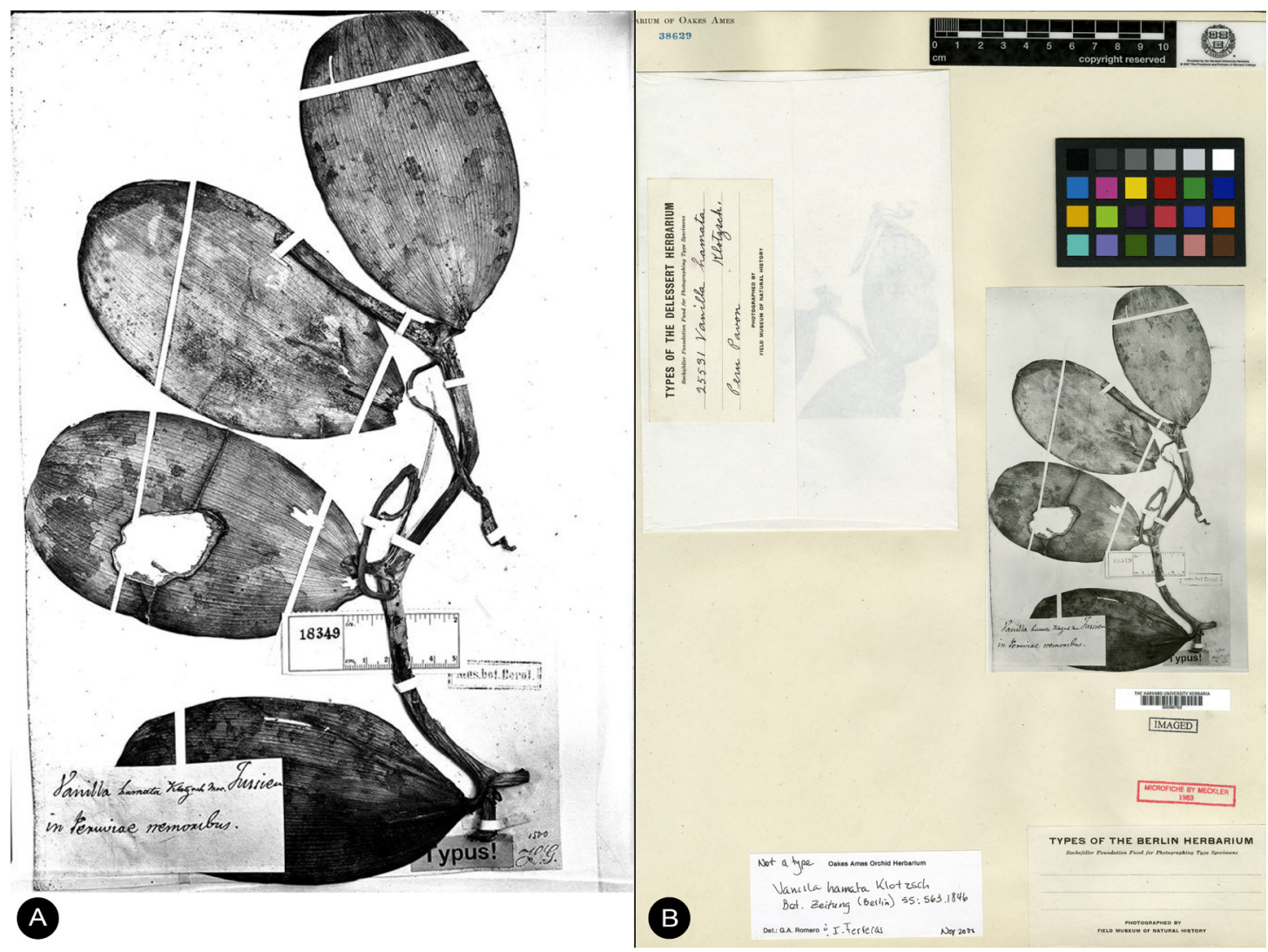

FIgURE 59. Vanilla pompona photographs of the holotype of $V$. hamata Klotzsch lost in Berlin. A. Neotype, photo kept at F-18349; (C) copyright of the Field Museum of Natural History, Chicago. B. Isoneotype, photo kept at AMES-38629; (C) copyright of Harvard University, Cambridge.

Syn.: Vanilla pittieri Schltr., Fedde Rep. 3: 106. 1906. Vanilla pompona subsp. pittieri (Schltr.) Dressler, Lankesteriana 9: 341. 2010.

TYPE: COSTA RICA. In der Wäldern an Ufern des Río Ceibo bei Buenos Aires, c. 200 m., blühend im Januar 1890, H. Pittier 6600 (holotype: B, destroyed; drawing of type, AMES!; lectotype designated here: BR-642325!, Fig. 61B; isolectotype, US!).

Syn.: Vanilla planifolia var. gigantea Hoehne, Relat. Commss. Linhas Telegr. Estratég. Matto Grosso Amazonas Annexo 5, Bot. pt. 1: 27-28, t. 5. 1910, syn. nov.

TYPE: [BRAZIL-PARAGUAY border]. Habitat ad silvis humidis secus flum. Jaurú et Paraguay, floret Setembri-Octobri, Pl. n. ${ }^{\circ} 972$ [lectotype designated here: Tabula No. 5 in Hoehne (1910)]

Syn.: Vanilla pleei Portères, Bull. Soc. Bot. France, 98: 94-95. 1951, syn. nov.
TYPE: MARTINIQUE, A. Plée 621 (syntypes: P-00612113!, P-00612114!; lectotype designated here by G. Leotard \& A.P. Karremans: P-00612114, Fig. 61C).

Syn.: Vanilla pseudopompona Soto Arenas, nom. nud. in sched., syn. nov.

Syn.: Vanilla cochlearilabia Archila, Chiron \& Menchaca, Richardiana, n.s. 3: 105-107. 2019, syn. nov.

TYPE: GUATEMALA. Alta Verapaz: margen sur del río Polochic, como planta trepadora. A 60 m.s.n.m. semidomesticada, Febrero 2001. FA-sn (BIGU; illustration!).

Hemiepiphytic, massive vine, little branched, leafy, up to $35 \mathrm{~m}$ high. Stems terete, smooth, pale green dotted with whitish, 10-28 mm thick; internodes 3.5$15 \mathrm{~cm}$ long. Aerial roots thick, $6 \mathrm{~cm}$ long, attaching roots conspicuously flattened on the lower surface, 

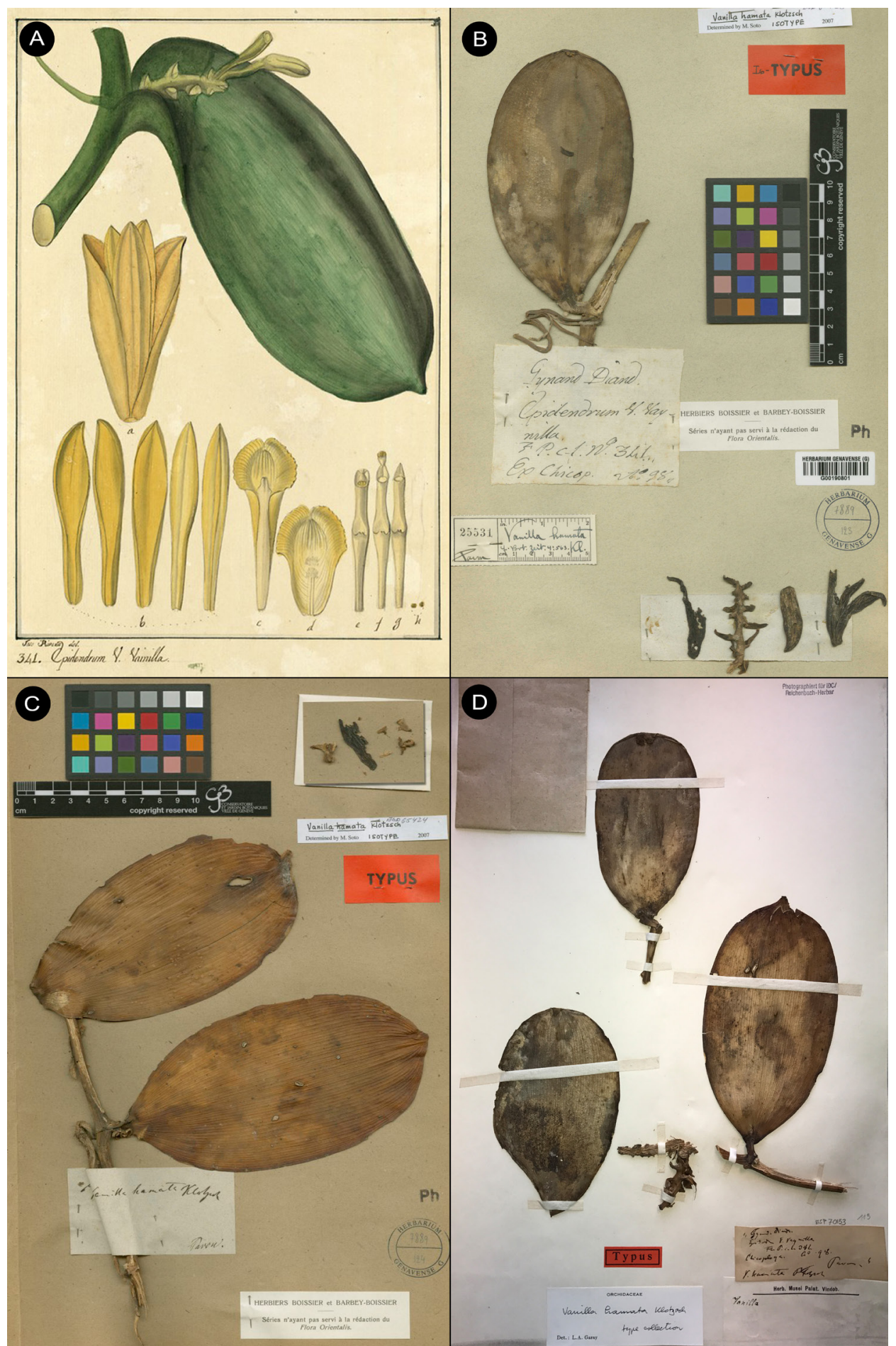

FigURE 60. Vanilla pompona material most likely the same collection as the type of $V$. hamata but not cited by the author. A. Illustration by J.G. Rivera N. 341 selected as epitype. B. G-7889/123. C. G-7889/124. D. W-19341. B-C C copyright of the Conservatoire et Jardin botaniques de la Ville de Genève. D photograph by APK. 


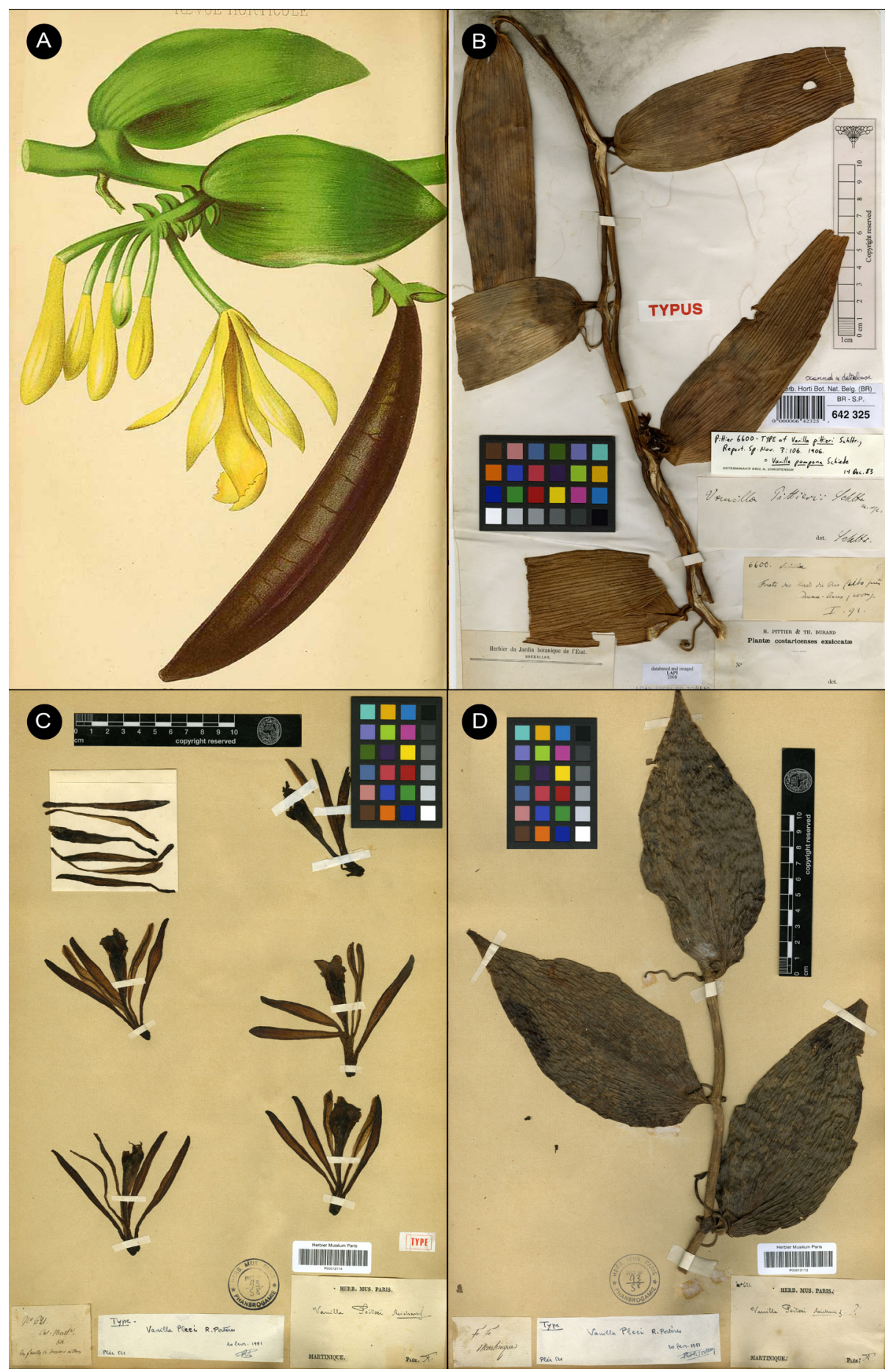

Figure 61. Vanilla pompona. A. Lectotype of $V$. lutescens Moq. ex Dupuis. B. Lectotype of $V$. pittieri Schltr. From Costa Rica (BR-642325). C. Lectotype of $V$. pleei Portères (P-00612114), based on Plée 621 a mixed collection from Martinique. D. Syntype of $V$. pleei which is here regarded as a different species (P-00612113). B C copyright of Meise Botanic Garden, Belgium. C-D (C) copyright of the Muséum national d'histoire naturelle, Paris. 
whitish-greenish; terrestrial roots pilose, $4 \mathrm{~mm}$ thick Leaves subsessile; blade variously shaped, ovate, widely elliptic, oblong falcate, base widely rounded to subcordate, 6-33 × $3.0-13.7 \mathrm{~cm}, 3 \mathrm{~mm}$ thick, coriaceous, very fleshy, brittle, pale green; apex acute to subapiculate. Inflorescence a raceme, producing 6-20 flowers, successive, 1 open at once, ephemeral; peduncle fleshy, subterete, $1 \mathrm{~cm}$ long; rachis up to 4.5 $\mathrm{cm}$ long. Floral bracts sessile, widely ovate, acute, concave, up to $5 \mathrm{~mm}$ long. Flowers tubular or with spreading segments, tepals pale yellow; lip orange yellow, very showy, column white in the base, light yellow to the apex; fragrance very strong, spicy, mintlike. Ovary arcuate, oval-subtrigonous in cross section, dorsiventrally flattened, arcuate, somewhat twisted, very slightly grooved on one face, smooth, green, 29-45 × 3-5 mm. Dorsal sepal long oblanceolate, apex obtuse to rounded, subcalyptrate, smooth and minutely warty abaxially to the apex, fleshy, ca. 2-4-veined; 52-105 × 7-16 mm, base long attenuate. Lateral sepals long oblanceolate, oblique, apex obtuse to rounded, subcalyptrate, smooth and minutely warty abaxially to the apex, fleshy, ca. 13-veined; 73-94 $\times$ 4-20 mm, base long attenuate, canaliculated. Petals oblanceolate-oblong, arcuate, slightly sigmoid and oblique, the upper margin more straight, apex truncate to rounded, ca. 12-veined, $59-80 \times 8-16 \mathrm{~mm}$. Lip attached to the column along the margins of the basal half for ca. $30-40 \mathrm{~mm}$, tubular, trumped-shaped, cymbiform, deepest near the middle, axially grooved; when spread out $60-80 \times 29-41 \mathrm{~mm}$; unguiculate, the claw canaliculate, with rows of trichomes; the blade flabellate to obscurely trilobed, margin undulate, ca. 40-veined, apex deeply emarginate-bilobed; lateral lobes long triangular-ovate, oblique, rounded, 30-40 $\times 10-25 \mathrm{~mm}$, erect surrounding the column, generally no overlapping; midlobe inconspicuous, the margins fairly reflexed, revolute, deeply bilobed; penicillate callus at 35-40 mm from the lip base, made up by ca. 10-14 congested, retrorse, approximately trapezoidal, laciniate scales, the scales regularly united each to other along the lateral margins, continuous with 3-6 thick and slightly warty veins forming a cushion like, claviform, rounded, rugose callus ending at the very apex. Column elongate, conspicuously sigmoid, 43-73 $\times 3-5 \mathrm{~mm}$, ventral surface lanuginose on the apical half, below the stigma; apex dilated, vertical wings triangular-flabellate, the lower margin acute, uncinate. Stigma trilobed, the lobes emergent, with a convex rostelum; lateral lobes divergent each to other, $2 \times 2$ $\mathrm{mm}$. Anther cap basally hinged to the column, versatile, sub-cuadrate, 4-8×6-7 mm wide. Pollen not forming a clear pollinarium but a sticky, soft, subtriangular granular mass. Fruit variable, usually arcuate, trigonous, thick, green, blackish when ripen and strongly aromatic, $7.3-21.5 \mathrm{~cm}$ long, ca. $14 \mathrm{~mm}$ thick

Specimens Studied: MEXICO: Guerrero. Sierra Madre, Guerrero- Michoacán, 400-1000 m, Mar. 1900, E. Langlassé 941 (AMES!). Vallecitos, Montes de Oca, 13 Sep. 1937, G.B. Hinton 11387 et al. (K!). Michoacan. Aquila, Tizupan, Coalcomán, 8 Apr. 1941, G.B. Hinton 15910 (AMES!). Sierra Madre, Guerrero-Michoacán, 400-1000 m, Mar. 1899, E. Langlassé 941 (AMES!, K!). Mpio. Aquila, San Pedro, Coalcomán, 550 m, 19 Jun. 1939, G.B. Hinton 13815 (AMES!). Oxaca. Near Mogoñé. Isthmus of Tehuantepec, $17^{\circ} 0^{\prime} \mathrm{N}, 95^{\circ} 01^{\prime} \mathrm{W}, 100 \mathrm{~m}, 18$ Feb. 1935, O. Nagel 4574 (AMES!). Specimens from the Gulf slope. Consoquilla, /42, Liebmann 288 (W-11761!). Pacific slopes of Sierra Madre, near Copalita and below Pluma Hidalgo, 26 Jul. 1936, 500$1000 \mathrm{~m}$, O. Nagel \& J. González 6102 (AMES!). Isthmus of Tehuantepec. Near Mogoñé, $17^{\circ} 0^{\prime} \mathrm{N}, 95^{\circ} 01^{\prime}$ W, 100 m, 20 Apr. 1935, H. Knape 4781 (AMES!, SEL!). Veracruz. Near Zacuapan. 12 Feb. $1932,19^{\circ} 12^{\prime} \mathrm{N}, 96^{\circ} 52^{\prime} \mathrm{W}$, ca. $900 \mathrm{~m}, O$. Nagel 2684 (AMES!). Municipio de Huatusco. Paraje El Angostillo, bajando a la barranca desde la Congregración El Pochote (34 km de Huatusco, $14 \mathrm{~km}$ de Manuel Gonzales), 500 m, 9 Abr. 2020, G.A Salazar, M.A Soto, M. Ingrouille \& P. Schluter 6162 (K!). Region of Zacuapan, ca. 800 m, Jun. 1935, C.A. Purpus 4852 (AMES!). Valle de Córdoba, 20 Apr. 1865-6, Bourgeau 2332 (K!). From Mexico. Secured by Prof. P.H. Rolfs, in charge of the Subtropical Laboratory, Miami, Fla., while traveling in Mexico as agricultural explorer of the Office of S \& PI in Apr., May, and Jun., 1905, David Fairchild 14440 (SEL!). Loc. H. de Higuera, 510 m, 8 Sep. 1966, M. Sousa 2721 (MO!). NICARAGUA: Cerro Livico, $7 \mathrm{~km}$ northeast of Siuna, forest slope; $500 \mathrm{~m}, 28 \mathrm{Apr}$. 1978, D. Neill 3670 (SEL!). Nueva Segovia. Quilalí, ca. $13^{\circ} 34^{\prime} \mathrm{N}, 86^{\circ} 01^{\prime} \mathrm{W}, 430 \mathrm{~m}, 16 \mathrm{Mar}$. 1980, W.D. Stevens and B.A. Krukoff 16829 (SEL!). Segovia. A.H. Heller s.n. (SEL!). Chontales. ca. $2.8 \mathrm{~km}$ above ( $\mathrm{N}$ of) Cuapa; ca. $12^{\circ} 17^{\prime} \mathrm{N}$, $85^{\circ} 23^{\prime} \mathrm{W}, 400-500 \mathrm{~m}$, B.A Stevens and Krukoff 3690 (SEL!). COSTA RICA: 2 Mar. 1931, C.H Lankester 1314 (AMES!). Alajuela. 4 Jun. 1963, A. Viquez s.n (USJ!). Guanacaste. Parque Nacional Guanacaste, Estación Maritza, sendero a la cima del Volcán Orosí, 1057.6’ N, 85²9.6' W, 600 m, 2 Jul. 1989, INBio 132 (CR!, SEL!). A 5 millas al sur de La Cruz, Liberia. 550 m, Ene. 1943, A.M Jiménez 27654 (CR!). A 5 millas al sur de La Cruz, Liberia. 200 m, 11 Feb. 1963, A.M 
Jiménez M. 313 (CR!). Puntarenas. Golfito, Jiménez, camino a Agua Buena, antes de la Estación Biológica Piro. Parcela Número 16, bosque muy húmedo, 8²3’34.61" N 83॰19'19.57' W, 98 m, 27 Oct. 2014, A.P. Karremans 6438, J. Geml, M. Lopez, J. Murillo, L. Parra, C. Rojo \& M. Vázquez (JBL-spirit!, Fig. 61, 62A). Cantón de Buenos Aires. Along the Río Ceibo, Ujarrás. $9^{\circ} 14^{\prime} 00^{\prime \prime} \mathrm{N}, 83^{\circ} 18^{\prime} 00^{\prime} \mathrm{W}, 500$ m, 9 Mar. 1993, M.H. Grayum 10237 (CR!). Golfito, Puerto Jiménez, Área de Conservación Oso. Poblado Piro. Finca Osa Verde, $8^{\circ} 24^{\prime} 00^{\prime \prime} \mathrm{N}, 83^{\circ} 20^{\prime} 40^{\prime \prime} \mathrm{W}, 50 \mathrm{~m}, 19$ Feb. 2016, D. Rodríguez s.n (USJ!). Buenos Aires, cuenca Térraba-Sierpe. Union del Río General con Río Coto Brus. Entre Guadalupe

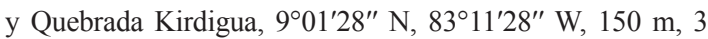
Mar. 2000, B. Hammel 22080, R. Aguilar \& E. Alfaro (USJ!). San José. Montes de Oca. Campus de la Universidad de Costa Rica. Jardín Botánico José María Orozco, 1160 m, 23 Abr. 1999, C.O Morales 1354 (USJ!). San José. Pie del Turrubares, 150 m, 6 Mar. 1926, A. Alfaro 269 (AMES!, MO!). Turrucares, Nov. 1978, J. Hale s.n (USJ!). Without locality data, Endres 270 (W-16188!, W-16230!, W-16231!, W-16175!, W-16176!). PANAMA: Along R. Tecumen, north of Chepo road, up to $30 \mathrm{~m}, 10 \mathrm{Mar}$. 1935, A.A. Hunter \& P.H. Allen 852 (MO!, AMES!). Near Canal Zone, C.V. Piper s.n. (AMES!). Canal Zone, Vicinity Cerro Viejo, 13 Oct. 1965, K.E. Blum 1235 (MO!). Canal Zone, along road to radar station on semaphore Hill, $1 \mathrm{~km} \mathrm{~N}$ of Summit Garden, 20 0ct. 1973, 100-150, M. Nee 7488 (MO!). Smithsonian Tropical Research Institute in Balboa, 18 Mar. 1979, J.D. Ackerman 1354 (SEL!). Vicinity Santa Fe, Río Santa María, 26 Mar. 1947, 305 m, P.H. Allen 4428 (MO!). Moist woods, large herbaceous vine, Río Paraíso, above East Paraíso, January 7 , 1924, P.C. Standley 29919 (AMES!). Canal Zone, Summit Garden, 8 m, 19 May 1970, T. Croat 10282 (MO!). Azuero Peninsula, along trail between Jobero and Headwaters of río Pedregal, 300-700 m, 28 Apr. 1976, T. Croat 34472 (MO!). Along trail between Jobero and Headwaters of Río Pedregal, 500-780 m, 29 Apr. 1976, T. Croat 34539 (MO!). Barro Colorado Island, shores of Gatum Lake, South of Lab., 28. Aug.1929, W.N. Bangham 458 (AMES!). JAMAICA: Caterfor Garden, 1892, $7206 x$ (K!). 4 Dec. 1891, W. Fawcett s.n. (K!). VENEZUELA: Río Negro, Amazonas, selvas pluviales en los alrededores de San Carlos de Río Negro, $1^{\circ} 50^{\prime} \mathrm{S}, 66^{\circ} 55^{\prime} \mathrm{W}$, B. Stergios s.n. \& C. Aymard (MO!). Alto Orinoco. El Motin, 13 Sept. 1951, L. Croizat 610 (F1821821!). Trinidad and Tobago: ca. 5 mi. Arima-Blanch. Rd., 16 May 1984, J.S. Kenny 29085 (U!). Hts. of Aripe, 09 May 1985, J.S. Kenny 29489 (U!). Tobago, Menna, 17 Jul. 1913, W. E. Broadway 4565 (GH-00600238!). FRENCH GUIANA: Basin of Rupununi River, 15 Sep. 1937, A.C. Smith 2474 (P!). Face Nort Est, Haut de Cricue Armontabo Ouest bas Oyapock, Cremers 776 (P!). Roche Touatou, Bassin de l'Oyapock, 52³2' S, 257' W, 160 m, G. Cremers 13931 \& Granville (P!). Saut Pierkourou sur le Tampok, 30
Oct. 1981, Moretti 1274 (P!). COLOMBIA: Plants of Santa Marta, 1898, H. Smith 1901 (AMES!). Plants of Santa Marta, 1898-1901, H. Smith 2369 (GH-02158563!). Plants of Santa Marta, 1898-1901, H. Smith 2371 (F-139112!). Dept. Vaupés, Cerro de Ypobodá, savannah, among scrub, at the headwater of Río Kuduyarí, ca. 600 ft., 15 Aug. 1960, L.A Garay 118 (AMES!). Las palmitas, Ocaña, Wallis s.n. (W-21448!). Santander, Piedecuesta, 1100 m, 1 Jun. 2007, J.F. Caroprese 006 (COL-000257421!; COL-000257420!). Santander, Girón, ca. 1000 m, 20 Ene. 2007, J.F. Caroprese 007 (COL000430711 !, stem with large leaves, the second stem with small leaves is $V$. phaeantha). Vaupés, Río Kuduyarí, Yapobodá, sandstone savannah near headwaters, 18 Nov. 1952, R.E. Schultes \& I. Cabrera 18490 (AMES!). Vaupés Río Vaupés, Mitú and vicinity. at base of Cerro Mitú, 27 Sep. 1966, R. E. Schultes, R. F. Raffauf \& D. Soejarto 24204 (AMES-02158577!). Pereira, S. Vieira-Uribe s.n. (JBLphoto!, Fig. 63Cc). SURINAME: Paramaribo, Wullschlaegell s.n. (W-35435!). GUYANA: Conrentyne River, British Guiana, G.S. Jenman s.n. (P-00612148!). PERU: [Huanuco, Prov. Huamalies, Dtto. Monzon] Chicoplaya, Flora Peruviana et Chilensis N. 341 (G-7889/123!, G-7889/124!, MA810866!, MA-810867!, W-19341!). Loreto: Prov. Maynas, Dtto. Belén, Caserío San Antonio, Rio Itaya, 145 m, Sep. 1929, L. Williams 3399 (F!); Prov. Maynas, vicinity of Quistococha, 73 20' W, 3 45' S, 150 m, 21 Feb. 1979, A. Gentry, J. Aronson, R. Vasquez 24829 (USM!). Madre de Dios: Prov. Manu, Puerto Maldonado, los amigos biológica station, madre de dios river, $7 \mathrm{~km}$ upriver from mouth of rio los amigos, trocha aguajal, -12.57 -70.1, 270 m, 5 Mar. 2003, M. Chocce 296 (USM!); Madre de Dios river, 7 km upriver from mouth of rio los amigos. M. flexuosa, aguaje palm swamp, aguajal to the northwest of the los amigos biological station, -12.57 -70.1 270 m, 19 Aug. 2002, J. Janovec \& A. Maceda 2671 (USM!, BRIT!, Fig. 63D); Prov. Tambopata, Puerto Maldonado, Aguajal Huitoto, albergue maquisapa,12.62, -69.94, 230 m, 18 Oct. 2004, M. Chocce, F. Cornejo, J. Janovec, A. Maceda, M. Tobler \& U. Falla 599, 660 (USM!); Prov. Manu, Boca Colorado, Aguajal Colorado, -12.47 -70.51, 270 m, 27 Oct. 2004, M. Chocce, F. Cornejo, J. Janovec, A. Maceda, M. Tobler \& U. Falla 684 (USM!); Prov. Tambopata, Puerto Maldonado, Aguajal Tormenta, -12.4308 -69.008, 190 m, 20 Aug. 2015, J. Wells, M. Escalante 1306[flor], 1307, 1310-1321 (MOL!); Prov. Tambopata, Puerto Maldonado, Aguajal Complex La Cachuela, -12.5316-69.1885, 186 m, 8 Aug. 2015, J. Wells \& M. Huinga 1278-1285 (MOL!); Prov. Manu, Dtto. Huaypetue, Zona Amortiguamiento Reserva Comunal Amarakaeri, Sector Setapo, 2013, 320 m, A. Damián s.n. (HUPCH!); Prov. Tambopata, Puerto Maldonado, cart. Nueva alianza, aguajal tormenta, -12.4317 -69.0553, 190 m, 20 Aug. 2015, J. Wells, M. Huinga 1324 (MOL!). San Martin: Zepelacio, near Moyobamba, june 1934, 110 m, G. Klug 3685 (F-752921!); 
Prov. Rioja, Dtto. Posic, Palestina, Yuracyacu, Tambo, 18M 0240151; 9345988 - 850 m, J. Edquen 140 (URP!); Rioja, Dtto. Naranjos, al costado de la carretera, cultivada por INIBICO, M. Leon s.n. (USM!). BOLIVIA: San Cruz, 3 km $\mathrm{N}$ of Buena Vista, road to Laguna Madrejon, $17^{\circ} 25^{\prime} \mathrm{S}, 63^{\circ} 40^{\prime}$ W, 315 m, 19 May 1991, A. Gentry 740901 (MO!). Guarayos. Reserva de vida silvestre ríos Blanco y Negro. Río San Martín (Concesión Oquiriquia). Campamento de la monita, 18 km al SW del Río San Martín. 1503'20.6" S, 6156'23" W. elev. ca. 250 m, 7 Sept. 1993, I. G. Vargas, N. Tagua \& J. Aguirre 2756 (F-2295770!). Amazon Basin, pampa near Oxiamas, 700-800 ft., 20 Dec. 1921, O.E. White 2336 (AMES!). Amazon Basin, near mouth of Río San José, 900$1000 \mathrm{ft} ., 14$ Oct. 1921, O.E. White 898 (AMES!). BRAZIL: Mato Grosso. Grounds of brick factory. $5 \mathrm{~km}$. south of Chavantina, margin of creek, Serra do Roncador, 26 Sept. 1964, G.T. Prance 59138 (US-00319619!; NY-00910931; UB-0019164!). Pará, Vigia, 26 Sept. 1964, E. Oliveira 3155 (IAN-116115!). Rondonia, Porto Velho, 19 Oct. 2015, M. Fragomeni Simon 2617 (CEN-00095226!). Maranhão: Caxias, Área de Proteção Ambiental Municipal do Inhamum (APA Inhamum), M.S. de Oliveira et al. s.n. [photographs in Ferreira et al. (2017)!]. Amazonas Rio Branco, Apr. 1913, J.G. Kuhlmann 415 (AMES!; RB-00260191!). Goiás, Cavalcante. Chapada dos Veadeiros, ca. $8 \mathrm{~km}$ south of Cavalcante, 10 Mar. 1969, H.S. Irwin et al. 24207 (NY00910928!). Manaus, Amazonas, Estrada do Aleixo, Secretaria de Produção, 4 Oct. 1978, P.I.S. Braga 3595 (INPA!). Manaus, Amazonas, Km 9 da BR-17. T. firme, argiloso. Habitat, capoeira aberta, 22 Jul. 1955, J.C. de Almeida 1470 (INPA!). Bahía, Entre Ríos, Algodão, $12^{\circ} 10^{\prime} 0^{\prime \prime}$ S, 3758'0" W, 100 m, 2009, A.V. Popovkin 9/16 (HUEFS!). Pernambuco, E.M. Pessoa s.n. (JBL-photo!, Fig. 63B).

Distribution: A very broadly distributed species in the Neotropics, found in Mexico, Guatemala, Nicaragua, Costa Rica, Panama, Jamaica, Puerto Rico, Guadeloupe, Dominica, Martinique, Trinidad \& Tobago, Colombia, Venezuela, French Guiana, Suriname, Guyana, Ecuador, Peru, Bolivia, Brazil and Paraguay (Fig. 55B).

\section{EXTENT OF OCCURRENCE: $15,763,473.161 \mathrm{~km}^{2}$.}

This robust and widely distributed taxon has been described several times through the years, at least four times in the 18th century, twice in the 19th century, and once more very recently. The first name applicable to this species is Vanilla pompona, a name proposed by Schiede in 1827 based on Mexican material. All of Schiede's original material of this species is sterile, but the thick stem and broad, coriaceous leaves, as also mentioned in the description "maxima, foliis oblingis, succulentis, subinde latissimis, et basi subcordatis", are unmistakable. The exact opposite happened with the second name that applies to this taxon. In 1840, Lindley proposed Vanilla grandiflora on the basis of a specimen from French Guiana composed only of a cluster of large yellow flowers on a short inflorescence. The vegetative features were unknown to the author and were not mentioned, but a very detailed illustration of the flowers are congruent with our concept of $V$. pompona.

A few years later, Klotzsch proposed Vanilla hamata from Peru, also based on a sterile specimen. The author described the leaves as obovate, broad, shortly petiolate and with a small hook at the apex. Soto Arenas \& Cribb (2010) suggested it was related to $V$. pompona, but the leaf shape prevented them from concluding the taxa were conspecific. This taxon remained obscure because of the relatively odd leaves and unavailability of floral material (Rolfe 1896); and of course the loss of the physical type at the Berlin herbarium (photos of the holotype are kept at F and AMES; Fig. 59). Specimens from the same expedition and with an extremely similar vegetative morphology have been identified as isotypes at G, MA and W (G-7889/123!, G-7889/124!, MA810866!, MA-810867!, W-19341!; Fig. 60). Strictly speaking, none of those specimens are isotypes as there is no proof that Klotzsch ever saw or used any of them. Quite contrarily, the specimens at $\mathrm{G}$ and $\mathrm{W}$ have flowers and the annotation "Chicoplaya, Flora Peruviana et Chilensis, N. 341", neither mentioned by Klotzsch. Even though it is very likely these are all materials belonging to the original collection, it is impossible to associate them without a doubt to $V$. hamata. For this reason we select the original photo of the holotype as a neotype, and select the illustration by J.G. Rivera (N. 341) as epitype (reproduced in Pupulin 2012). Even though the leaves of the type of $V$. hamata have an odd shape for this species, the illustration shows the typical thick stem, broad leaves, short inflorescence, and yellow flowers of $V$. pompona. We do not discard the possibility of a mixed collection. One of us (AD) has confirmed the presence of $V$. pompona in the area were the type of $V$. hamata is believed to have been collected.

Not long after, this species was again described under the name Vanilla lutescens Moq. ex Dupuis, based on a specimen from Guayra (La Guaira, Venezuela, not Paraguay as stated). A very good 
illustration and description is provided for this taxon, again showing a thick stem, broad leaves, a short inflorescence, and large yellow flowers. None of these four taxa were compared to each other when proposed; perhaps on account of the partial materials and the distant geographical locations from which they were described (Mexico, Venezuela, French Guiana, Peru). Rolfe (1896) had already suggested $V$. pompona, $V$. grandiflora and $V$. lutescens were conspecific more than a century ago; $V$. hamata can be added now that the original drawing has surfaced.

The species was described once again as Vanilla pittieri Schltr. in 1906 based on a specimen collected in Río Ceibo, close to Buenos Aires, Costa Rica. The author compared the taxon to $V$. pompona suggesting a few differences. However, at the type locality we have observed specimens that are indistinguishable from $V$. pompona; a specimen collected in the same area, and morphologically similar to the type material, is illustrated here (Fig. 62). Vanilla planifolia var. gigantea Hoehne proposed in 1910 was believed to be a large variety of $V$. planifolia by the original author, and placed under $V$. hostmannii Rolfe by Soto Arenas \& Cribb (2010). But the large leaves, thick stem, short inflorescence bearing relatively small yellow flowers are referable to $V$. pompona instead. Another name placed here under the synonymy of Vanilla pompona is V. pleei Portères, described in 1951 based on material from Martinique. Soto Arenas \& Cribb (2010) were unable to access original material of this taxon, but Garay \& Sweet (1974) suspected it was based on a mixed collection, composed of leaves of $V$. mexicana and flowers of $V$. pompona. We agree with the later, Plée 621 is a mixed collection composed of two sheets, one includes leaves of what appears to be $V$. mexicana, or a related species, and a second with flowers of $V$. pompona. Both the protologue and the illustration of the type published by Portères (1954) are a mixture of both species. We here select the sheet with flowers as lectotype because they can be identified more accurately than the sterile leaves, and therefore the name $V$. pleei is included under the synonymy of $V$. pompona.

Soto Arenas believed $V$. pompona to be a species complex, with the isolated populations in Mexico, southern Central America, and north-west south America, possibly representing separate species. His
DNA-based studies did not support this hypothesis, and the three populations were treated as subspecies in Soto Arenas \& Dressler (2010). However, we can't find any consistent morphological differences between plants from those geographical areas, and as our knowledge on Vanilla grows the gaps between the populations disappear. Specimens of $V$. pompona have now been reported from Guatemala, described under the name V. cochlearilabia, closing the gap between populations in Mexico and southern Central America. While in South America, specimens from Bolivia, Colombia, Ecuador, Peru, type of $V$. hamata and Venezuela, type of $V$. lutescens, confirm that the species is not restricted to the north west, and in fact grades into the southern Central American populations. Even though some specimens indeed show the larger, narrower flowers, with spreading segments, these features are variable even within a single population and the time of day. Subgeneric distinction is not supported either. The type illustration of $V$. lutescens (Fig. 58, above) and type specimen of $V$. pompona subsp. grandiflora (Fig. 58, below) are indistinguishable from the specimens found in southern Costa Rica described as $V$. pompona subsp. pittieri (Fig. 62, 63A), and even if the larger flowered $V$. pompona individuals should be recognized as a distinct taxon in the future, none of these names would apply to it. It is noteworthy that Vanilla pompona has been shown to be pollinated exclusively by male Eulaema cingulata in both Costa Rica and Peru (Watteyn, Scaccabarozzi, et al. in prep.).

Endrés used the name "Vanilla reichenbachii Endrés" on specimens of Vanilla pompona from Costa Rica. Like many other names intended by the author, it was never formally published. Soto Arenas used the name "Vanilla pseudopompona Soto Arenas" on a specimen from Panama that he later determined as $V$. pompona subsp. pittieri. A few authors have cited this name as an accepted species of Vanilla, but it was never formally published and its use should be avoided.

Vanilla pompona is characterized by having a robust stem, up to $3 \mathrm{~cm}$ in diameter, the leaves are succulent, ovate, elliptic to oblong, with a rounded to subcordate base. The inflorescence is short, bearing yellow flowers. The lip is large and trumpet shaped, obscurely trilobed, with undulate margins and elevated rows of papillae from the penicillate callus to the apex. 


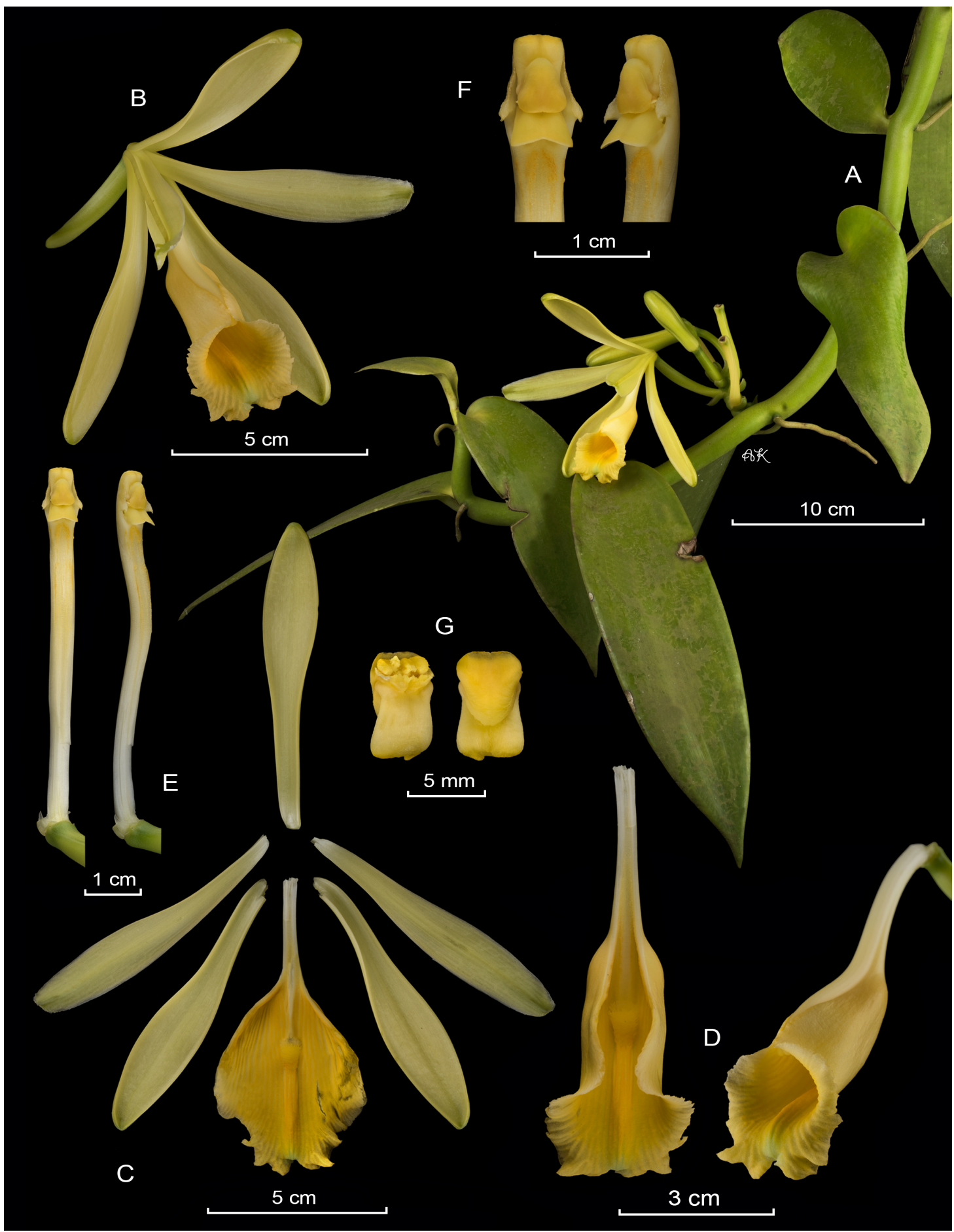

Figure 62. LCDP of Vanilla pompona. A. Habit. B. Flower. C. Dissected perianth, flattened. D. Lip and column lateral view. E. Lip in natural position, column removed. F. Column, ventral and lateral view. G. Column apex showing the anther cap and rostellar flap. H. Anther cap and pollinia. By IC \& APK based on Karremans 6438 (JBL-spirit). 


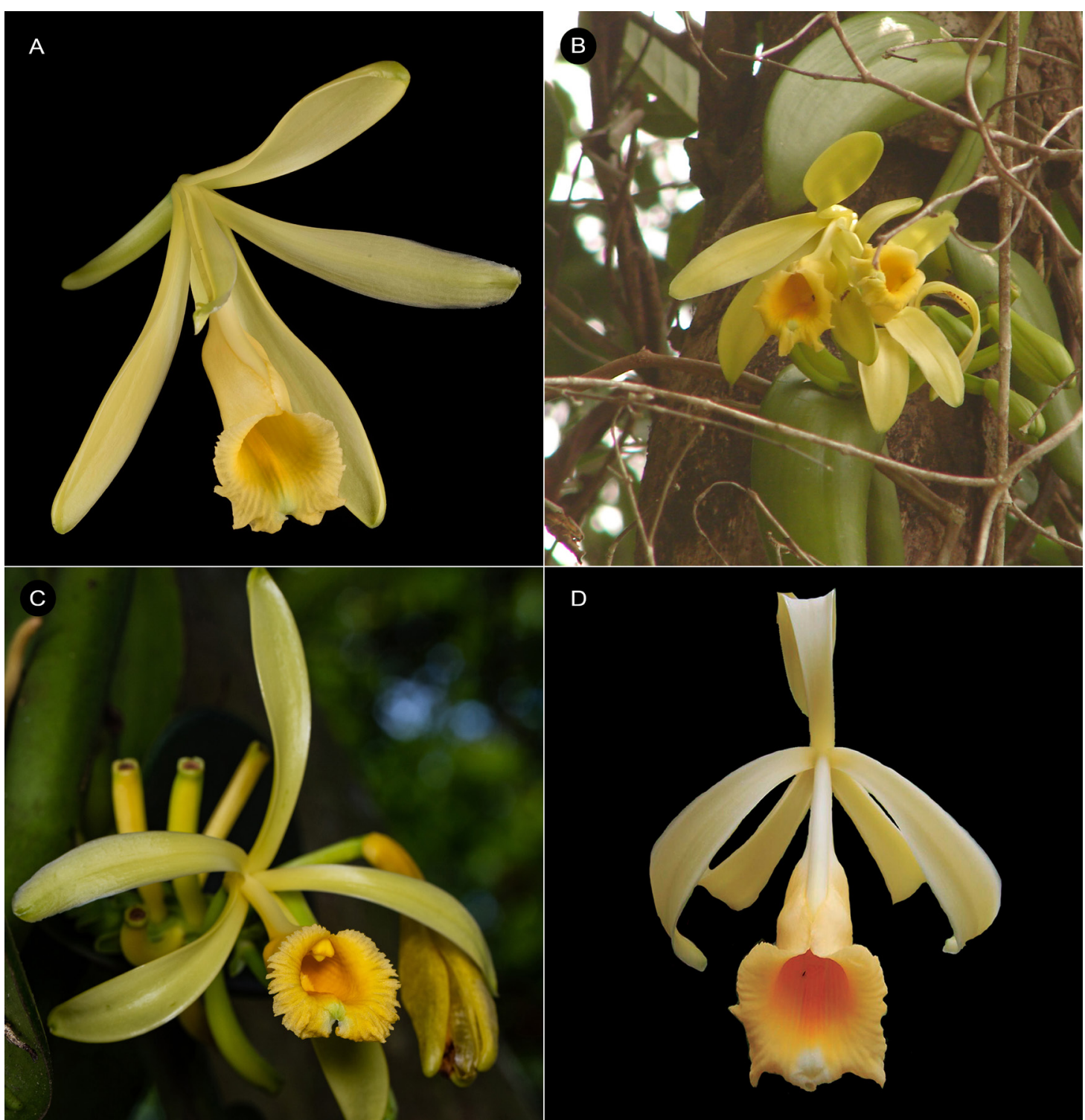

FIgURE 63. Vanilla pompona different flowering specimens showing variations across its geographical range. B. Costa Rica, Osa, Karremans 6438. B. Brazil, Pernambuco, E.M. Pessoa s.n. C. Colombia, Pereira, S. Vieira-Uribe s.n. D. Peru, Madre de Dios, J. Janovec \& A. Maceda 2671. All photographs by the collectors kept at JBL.

Conclusions. Since the meticulous revisions published by Soto Arenas \& Dressler (2010) and Soto Arenas \& Cribb (2010), 20 species of Vanilla have described from the Neotropics. In this study we found that half of them were conspecific with previously, sometimes poorly, known and widespread species. At this time 62 Vanilla species, can be attributed to the Neotropics, with 18 membranaceous species belonging to Vanilla subgen. Vanilla, six Antillean endemic species that belong to Vanilla sect. Tethya Soto Arenas \& P.J. Cribb, and 38 species, which have fragrant fruits and belong to Vanilla sect. Xanata. A current state of Vanilla taxonomy in the region summarizing these and previous findings is provided (Table 1).

Our study is not exhaustive of all Neotropical Vanilla. A lack of living material to illustrate some of the taxa appropriately, as well as a scarcity and state of the herbarium material, prevents us from 
TABLE 1. List of accepted Neotropical Vanilla species*.

Species

Publication

Vanilla subgen. Vanilla (Membranaceous Vanilla)

\begin{tabular}{l|l}
\hline Vanilla acuta Rolfe & J. Linn. Soc., Bot. 32: 453. 1896. \\
\hline Vanilla angustipetala Schltr. & Anexos Mem. Inst. Butantan Secç. Bot. 1(4): 19.1922. \\
\hline Vanilla arcuata Pansarin \& M.R.Miranda & Phytotaxa 267: 80. 2016. \\
\hline Vanilla armoriquensis Damián \& Mitidieri & Phytotaxa 451(2): 158-159. 2020. \\
\hline Vanilla bertoniensis Bertoni & Anales Ci. Parag. 8: 10. 1910. \\
\hline Vanilla bradei Schltr. ex Mansf. & Repert. Spec. Nov. Regni Veg. 24: 243. 1928. \\
\hline Vanilla costaricensis Soto Arenas & Lankesteriana 9: 297. 2010. \\
\hline Vanilla dietschiana Edwall & Revista Centro Sci. Campinas 2: 192. 1903. \\
\hline Vanilla edwallii Hoehne & Arq. Bot. Estado São Paulo n.s. f.m. 1: 61. 1941. \\
\hline Vanilla guianensis Splitg. & Ann. Sci. Nat. Bot. sér. 2 15: 279. 1841. \\
\hline Vanilla inodora Schiede & Linnaea 4: 574. 1829. \\
\hline Vanilla methonica Rchb.f. \& Warsz. & Bonplandia (Hannover) 2: 97.1854. \\
\hline Vanilla mexicana Mill. & Gard. Dict. ed. 8: n. ${ }^{\circ}$ 1. 1768. \\
\hline Vanilla organensis Rolfe & J. Linn. Soc. Bot. 32: 452. 1896. \\
\hline Vanilla oroana Dodson & Orquideologia 22: 210. 2003. \\
\hline Vanilla parvifolia Barb.Rodr. & Gen. Spec. Orchid. 2: 271. 1882. \\
\hline Vanilla sarapiquensis Soto Arenas & Lankesteriana 9: 342. 2010. \\
\hline Vanilla verrucosa Hauman & Anales Mus. Nac. Hist. Nat. Buenos Aires 29: 365. 1917. \\
\hline
\end{tabular}

Vanilla sect. Tethya

Vanilla bakeri Schltr.

Vanilla barbellata Rchb.f.

Vanilla claviculata Sw.

Vanilla dilloniana Correll

Vanilla marmoreisensis Soto Calvo, Esperon \& Sauleda

Vanilla poitaei Rchb.f.
Repert. Spec. Nov. Regni Veg. 8: 561. 1910.

Flora 48: 274. 1865.

Nova Acta Regiae Soc. Sci. Upsal. 6: 66. 1799.

Amer. Orchid Soc. Bull. 15: 331. 1946.

New World Orchid. Nomencl. Notes 56: 2-7. 2019.

Linnaea 41: 66. 1876.

Vanilla sect. Xanata (Fragrant Vanilla)

\begin{tabular}{l|l}
\hline Vanilla appendiculata Rolfe & Bull. Misc. Inform. Kew 1895: 178. 1895. \\
\hline Vanilla bicolor Lindl. & Edwards's Bot. Reg. 24(Misc.): 37. 1838. \\
\hline Vanilla capixaba Fraga \& D.R.Couto & Phytotaxa 296(1): 64. 2017. \\
\hline Vanilla carinata Rolfe & J. Linn. Soc., Bot. 32: 468. 1896. \\
\hline Vanilla chamissonis Klotzsch & Bot. Zeitung (Berlin) 4: 564. 1846. \\
\hline Vanilla cobanensis Archila & Revista Guatemalensis 2(3): 47. 1999[2012]. \\
\hline Vanilla columbiana Rolfe & J. Linn. Soc. Bot. 32: 468. 1896. \\
\hline Vanilla corinnae Sambin \& Chiron & Richardiana n.s. 1: 26. 2017. \\
\hline Vanilla cribbiana Soto Arenas & Lankesteriana 9: 300. 2010. \\
\hline Vanilla dressleri Soto Arenas & Lankesteriana 9: 303. 2010. \\
\hline Vanilla duckei Huber & Bol. Mus. Goeldi Hist. Nat. Ethnogr. 5: 327. 1909. \\
\hline Vanilla dubia Hoehne & Arq. Bot. Estado São Paulo n.s. f.m. 1: 126. 1944.
\end{tabular}

(continues)

${ }^{*}$ The taxonomy follows Soto Arenas \& Cribb (2010) and Soto Arenas \& Dressler (2010), with a few modifications proposed by Ackerman (2014), the inclusion of recent novelties, and the changes proposed herein. However, it must be stressed that several taxa herein are still being revised in detail and it is already apparent that additional reductions will be proposed in the future. 
TABLE 1. (continues).

\begin{tabular}{|c|c|}
\hline Species & Publication \\
\hline Vanilla dungsii Pabst & Bradea 2: 49. 1975. \\
\hline Vanilla espondae Soto Arenas & Lankesteriana 9: 281. 2010. \\
\hline Vanilla fimbriata Rolfe & Bull. Misc. Inform. Kew, 1899: 133. 1899. \\
\hline Vanilla hartii Rolfe & Bull. Misc. Inform. Kew 1899: 133. 1899. \\
\hline Vanilla helleri A.D.Hawkes & Phytologia 14: 19. 1966. \\
\hline Vanilla hostmannii Rolfe & J. Linn. Soc. Bot. 32: 462. 1896. \\
\hline Vanilla inornata Sambin \& Chiron & Richardiana 15: 308. 2015. \\
\hline Vanilla insignis Ames & Bot. Mus. Leafl. 2: 101. 1934. \\
\hline Vanilla javieri Bar.-Colm. & Phytotaxa 375: 263. 2018. \\
\hline Vanilla karen-christianae Karremans \& P.Lehm. & Orchids (West Palm Beach) 87: 305. 2018. \\
\hline $\begin{array}{l}\text { Vanilla labellopapillata A.K.Koch, Fraga J.U.Santos } \\
\text { \& llk.-Borg. }\end{array}$ & Syst. Bot. 38: 975. 2013 [2014]. \\
\hline Vanilla marowynensis Pulle & Enum. Vasc. Pl. Surinam: 118. 1906. \\
\hline Vanilla odorata C.Presl & Reliq. Haenk. 1: 101. 1826. \\
\hline Vanilla palmarum (Salzm. ex Lindl.) Lindl. & Gen. Sp. Orchid. PI.: 436. 1840. \\
\hline Vanilla paulista Fraga \& Pansarin & Phytotaxa 296: 66. 2017. \\
\hline Vanilla penicillata Garay \& Dunst. & Venez. Orchids III. 3: 324. 1965. \\
\hline Vanilla phaeantha Rchb.f. & Flora 48: 274.1865. \\
\hline Vanilla planifolia Andrews & Bot. Repos. 8: t. 538. 1808. \\
\hline Vanilla pompona Schiede & Linnaea 4: 573. 1829. \\
\hline Vanilla ribeiroi Hoehne & $\begin{array}{l}\text { Relat. Commiss. Linhas Telegr. Estratég. Matto Grosso } \\
\text { Amazonas 1: 28. } 1910 .\end{array}$ \\
\hline $\begin{array}{l}\text { Vanilla rivasii Molineros, R.T.González, Flanagan } \\
\text { \& J.T.Otero }\end{array}$ & Lankesteriana 13: 354. 2014. \\
\hline Vanilla ruiziana Klotzsch & Bot. Zeitung (Berlin) 4: 563. 1846. \\
\hline Vanilla sprucei Rolfe & J. Linn. Soc. Bot. 32: 461.1896. \\
\hline Vanilla trigonocarpa Hoehne & Arq. Bot. Estado São Paulo n.s. f.m. 1: 126. 1944. \\
\hline Vanilla vellozoi Rolfe & J. Linn. Soc. Bot. 32: 467. 1896. \\
\hline Vanilla weberbaueriana Kraenzl. & Bot. Jahrb. Syst. 37: 395. 1906. \\
\hline Vanilla $\times$ tahitensis J.W.Moore & Bull. Bernice P. Bishop Mus. 102: 25. 1933. \\
\hline
\end{tabular}

extending this study to other species at this time However, it is a pressing necessity. About a dozen or so names from the $19^{\text {th }}$ and early $20^{\text {th }}$ centuries apply to taxa that remain cryptic. Once understood, they are likely to have priority over more recently recognized Vanilla species. For example Vanilla cobanensis Archila [2012] is certainly a synonym of $V$. cribbiana Soto Arenas [2010], the obscure V. sprucei Rolfe [1896] is perhaps an earlier name for $V$. trigonocarpa Hoehne [1944], while Vanilla columbiana Rolfe [1896], Vanilla carinata Rolfe [1896] and V. vellozii Rolfe [1896] are all closely related to $V$. chamissonis Klotzsch [1846], V. marmoreisensis Soto Calvo et al. [2019] is quite similar to $V$. barbellata Rchb.f. [1865],
V. verrucosa Hauman [1917] may be the first name for $V$. angustipetala Schltr. [1922], V. paulista Fraga \& Pansarin [2017] is very close to $V$. dubia Hoehne [1944], V. capixaba Fraga \& D.R.Couto [2017] is probably closely related to V. ribeiroi Hoehne [1910], V. labellopapillata Koch et al. [2014] shows some resemblance to $V$. fimbriata [1899] and V. insignis Ames [1934], and V. javieri Bar.-Colm. [2018] is reminiscent of $V$. purusara Hoehne [1944]. There are surely several distinct species among these taxa, but it is also certain that a few will turn out to be further synonyms after thorough inspection, and it is highly desirable that these taxa are well understood before proposing further novelties. 
Sangster (2009) argues that the growth in species numbers results from progress in taxonomy and benefits other disciplines. We agree with the author that our knowledge on poorly known groups may increase in this way, but it is only a progress in taxonomy when studies are carried out rigorously and previously proposed taxa are clarified and well delimited. An ill-defined and poorly illustrated novelty that is not placed in any ecological and systematic framework is a problem rather than a taxonomical advancement. Even though undescribed species may indeed be discovered in the future, we believe that, contrary to other highly diverse Neotropical orchid genera, the number of names in Vanilla today is likely to exceed the number of actual species. Dealing with these names may seem merely a taxonomic endeavor of little consequence, nevertheless significant taxonomic inflation may result in an overestimation in speciation rates, the underestimation of ecological preferences and distribution ranges, false interpretations of endemisms and hotspots, skewed origin and diversification patterns, mistaken conservation priorities, and increased interest of collectors, among other issues previously mentioned (Isaac et al. 2004, Zachos et al. 2013, Garnett \& Christidis 2017). We agree with Geiger (2020) and Geiger et al. (2020) that taxonomical "cleanups" may have profound implications for our understanding of diverse groups within the Orchidaceae.

Furthermore the extremely broad distributions of Vanilla species, both geographically and ecologically, is an unusual phenomenon in the Orchidaceae that warrants further study. We do not (re)assess the conservation status of these Vanilla species here, but offer useful information to do so in the future. The Extent of Occurrence (EOO), which is estimated by drawing a polygon over the data points at the edge of the distribution, is a very rough initial assessment of the extent of a species' occurrence. It should not be taken as an estimate of the species' habitat as it does not exclude unsuitable habitats. However, it does say something about how broad the distribution of Vanilla species can be, and is indicative of a very effective dispersal mechanism coupled with a high plasticity in their ecological preferences. Three species, $V$. mexicana, $V$. phaeantha and $V$. pompona have an estimated EOO of above 14 and 15 million square kilometers which must be among the broadest distributions known in Orchidaceae. They are also among the most commonly found species in that broad distribution, with hundreds of vouchers available. They are followed by $V$. hartii and $V$. odorata, the first with an EOO just above four million square kilometers, and the latter close to 10 million $\mathrm{km}^{2}$. Both have relatively small plants, and do not become as massive as the previous. It is unclear if the are indeed less common and have a narrower distribution, or have simply been overlooked by collectors. Vanilla karen-christianae and V. marowynensis are unusual in comparison to the other species discussed here. Both have a relatively broad distribution with an EOO of little more than four million $\mathrm{km}^{2}$, but seem to be quite rare in that large extension. The two species with the smallest areas are $V$. columbiana and $V$. inodora, both below a million $\mathrm{km}^{2}$. Even though this still means they are found in several countries across their range, and may not necessarily be rare, the question remains as to why their distribution is more restricted. Some Vanilla species are rare and have restricted distributions within a country, warranting local conservation efforts. Such is the case of $V$. mexicana in Florida. Inferring the natural distribution of Vanilla planifolia has been challenging due to its widespread cultivation, it is found in the wild in Central America, but some collections from South American appear to have been made in the wild. We are unable at this time to be sure and have indicated that uncertainty with yellow (wild) and red (cultivated or uncertain) points in the map.

Further studies incorporating distribution and frequency data, as well as ecological requirements, will be needed to assess the conservation priorities among these Vanilla species. The Global Biodiversity Information Facility (GBIF) is one of the most important sources of raw data for accessing species occurrence records which are used to assess distributions in studies that go from inferring the impact of climate change and spread of invasive species, to determining priorities for conservation, food security and human health. The database relies on the correct determination of the specimen vouchers from which it feeds. Despite their best curation efforts specimens are not always correctly identified and most users will not or cannot double check them. Luckily digital vouchers are available in the GBIF gallery for some of the specimens in the database. A careful inspection of 
the vouchers for the ten species discussed in this paper reveals that all of them include incorrectly determined specimens, even when disregarding synonymies. In the case of $V$. hartii, $V$. odorata, $V$. phaeantha and $V$. pompona, the false positives represent up to $15 \%$ of the digitally available vouchers for those species. But in the case of $V$. inodora and $V$. mexicana incorrectly determined vouchers represent about $50 \%$ of all those available. What could be consequences for those studies on non-taxonomical if these misidentifications were generalized?

The adequate determination of taxa used in nontaxonomic biological studies is fundamental. Correctly determined taxa set a strong foundation in order to reach the research objectives and are essential for drawing robust conclusions. Hu et al. (2019) used genomics-based tools to characterize and identify genetic diversity in Vanilla. Among some of their key results is the relative low genetic variation found in Vanilla planifolia, the evidence of multiple hybrid accessions and the presence of misclassified accessions amongst those sampled. However, to identify the Vanilla accessions the authors used a "consensus" strategy, assigning names based on which one is more recurrent amongst its closest genetic relatives. Such indirect determinations of taxa may pose a serious methodological concern and can weaken conclusions based on them. Bouétard et al. (2010) dealt with the difficulty of identifying Vanilla accessions somewhat differently. In their study about half of the accessions were left as undetermined which unfortunately limits what can be inferred from them. Incorrectly determined or undetermined taxa may be highly detrimental to such studies, both by introducing errors in the conclusions that are drawn, as in masking others that are therefore not reached.

In their genetic studies of Vanilla planifolia and its relatives in the Yucatan Peninsula, VillanuevaViramontes et al. (2017) included accessions of an undetermined taxon that appeared to be isolated from all others. The authors presented photographs of the five taxa included in the study, and thanks to that it is possible not only to understand what the author's concept of each taxon is, but also to identify their undetermined taxon as Vanilla phaeantha, a species that is also found in Mexico. Montes de Oca-Vásquez et al. (2020) studied the effects of microhabitats on the soil and litter microbial communities associated with wild relatives of the Vanilla crop in the tropical rainforest in Costa Rica. The authors determined Vanilla plants using both "morphological traits and DNA barcoding", and indeed such a study cannot be effectively carried out without consistent determination of the taxa in the field. Photographs communicated to us by the authors confirm that Vanilla sp. 3 in their study is in fact $V$. hartii, a species that is relatively common in the study area. The use of a photograph mistakenly labeled V. planifolia in Gallage \& Møller (2018) indicates that also in agriculture and biotechnology there is confusion as to the correct identity of Vanilla cultivars, the consequences of which are not trivial.

This handful of examples prove the importance of both the availability of vouchers and the need of experts to determine them, even for non-taxonomical studies. We agree with Pupulin (2016) that alpha-taxonomy is fundamental to all of biology, and that the fundamental questions from disciplines such as speciation, diversification processes, ecosystem development, and conservation priorities depend on correct species boundaries and diversity estimates. In 2005, Robert Dressler stated "current attitudes favor molecular systematics... against old-fashioned taxonomy", pointing out that "most molecular work would be quite meaningless without "old-fashioned" identification and documentation of the samples analyzed" (Dressler 2005). Today, his cautionary statements are more true than ever. Molecular studies are a tool. A powerful source of information. Evidence to help support or disprove a hypothesis. They cannot, on their own, formulate the hypothesis. They are not a substitute for the socalled "old-fashioned" characterization and naming of species. Alpha-taxonomy will always be needed in biological studies that rely on the correct application of species' boundaries and species' names. The correct interpretation of boundaries and the application of names necessarily derives from the study of original texts, illustrations, and type specimens, as well as the biogeography and morphological variation found in extant populations. The misleading notion that DNAbased studies are somehow superior to and eliminate the necessity for alpha-taxonomy has become quite generalized among certain botanical institutions. To the point that alpha-taxonomical experts, and their work, is frequently looked down upon by their molecular- 
systematics counterparts. We would rather argue that the knowledge of these experts is invaluable and quite essential to set the bases for any serious biological study.

ACKNOWLEDGMENTS. We thank Rudolf Jenny for providing historic literature and illustrations. We are especially thankful to Ernst Vitek (W) and Bruno Wallnöfer (W), Phil Cribb (K) and André Schuiteman (K), Germán Carnevali (CICY) and Silvia Hernandez (CICY), Bruce Holst (SEL) and Shawn McCourt (SEL), Julio Betancur (COL) and Henry Agudelo Zamora (COL), and Eric Hágsater (AMO), Elizabeth Santiago Ayala (AMO) and Rolando Jimenez (AMO), all of who kindly provided access to and images of specimens kept in their collections. Rafaela Campostrini Forzza and Paula Leitman of the Projecto Reflora kindly provided several type images of Brazilian taxa. Sebastião Neto (HB) kindly provided photos of the type of $V$. denticulata. Franco Pupulin (JBL) aided in the analysis of the original materials of $V$. hamata and $V$. phaeantha. Mike Grayum (MO) is thanked for his considerations on E. rubrum and M. fragrans. Patrik Mráz (PRC) and Otakar Šída (PR) are thanked for their information on Haenke's collection. Antonio Toscano de Brito, Eric de Camargo Smidt, Edlley Pessoa are thanked for their help in retrieving relevant literature and specimens from Brazilian. Laure Pfeffer $(\mathrm{P})$ is thanked for her help in accessing Plumier's materials. Kanchi Gandhi kindly provided feedback on nomenclature. Alan Chambers is thanked for his feedback on phylogenetics. Diego Bogarín,
Yasmin Alomía, Sebastián Vieira-Uribe, Sebastián Moreno, Cassio van den Berg, Mathias Engels, Hermes Vega, Robert Tulio González, Edgar Alfredo Mo, Daniel Mauricio Díaz Rueda, José R. Ferrer-Paris, Keith Bradley, Giff Laube, Pierre Silland, Sébastien Sant, Claudine and Pierre Guezennec, Ken Cameron, Manfred Speckmaier, Bernal Azofeifa, and Eric Brylle and Marshall Nathanson of the Annona Breeding Project, are thanked for kindly sharing photographs used for this study. Maria Candida Mamede at Herbário do Instituto de Botânica (SP) and Ida Haerida and Suhendra Suwira at the Bogor Herbarium (BO) are also thanked. Dr. Mohanan K.V. Department of Botany, University of Calicut also provided literature. We also thank Erik Smets and Roxali Bijmoer at Naturalis and the staff of CR, USJ, JBL and MO. Nico Davin, Charlotte Watteyn, Frederike Stock, Ruth Pillco Huarcaya, Andy Whitworth, Marvin López, Ernesto Carman are thanked for their assistance in the field in Costa Rica. Osa Conservation is thanked for their continuous support. Two anonymous reviewers are thanked for their constructive comments on the manuscript. The Costa Rican Ministry of Environment and Energy (MINAE) and its National System of Conservation Areas (SINAC) provided the scientific permits for materials collected in Costa Rica. The Vicepresidency of Research of the University of Costa Rica supported the first author financially in visits to the K, L, SEL and W herbaria, and through research project 814-C0-049 "Diversidad genética y estructura clonal de las poblaciones silvestres de Vanilla en Costa Rica". AD expresses his gratitude to FONDECYT and UCSUR for funding the project "Genetic and morphological characterization of species of Vanilla (Orchidaceae) in Peru".

\section{LITERATURE CITED}

Ackerman, J.(2014).Orchid Flora of the Greater Antilles. NewYork: The New York Botanical Garden Press. 625pp.

Ames, O. (1934). An addition to the genus Vanilla. Botanical Museum Leaflets, Harvard University, 2(8), 101-103.

Anjos, A. M., Barbarena, F. F. V. A. \& Pigozzo, C. M. (2016) Biología reproductiva de Vanilla bahiana Hoehne (Orchidaceae). Orquidario, 30, 67-79.

Archila Morales, F. (2012). Hallazgos importantes en Vanilla/Orchidaceae de Jussieu, para Guatemala. Revista Guatemalensis, 2(3), 44-51.

Archila Morales, F. \& Chiron, G. R. (2012). Addition à la flore du Guatemala: Vanilla esquipulensis (Orchidaceae), espèce des forêts xérophytes. Richardiana, 13, 3-12.

Archila Morales, F., Menchaca, R. \& Chiron, G. R. (2019a). Notes on Mesoamerican orchids. I: Vanilla, with a new species. Richardiana, 3, 71-79.

Archila Morales, F., Menchaca, R. \& Chiron G. R. (2019b). Notes on Mesoamerican orchids. II: millenary use in the Q'eqchi communities of the lowlands, with a new Vanilla species. Richardiana, 3, 100-108.

Averyanov, L. V. (2011). The orchids of Vietnam illustrated survey. Part 3: Subfamily Epidendroideae (primitive tribes Neottieae, Vanilleae, Gastrodieae, Nervilieae). Turczaninowia, 14(2), 15-100.

Averyanov, L.V. \& Vuong, T.B. (2015). Review of the genus Miguelia (Orchidaceae) with a new species, M. cruenta, from southern Vietnam. Taiwania, 60(1), 33-38. doi: 10.6165/tai.2015.60.1.33

Azofeifa-Bolaños, J. B., Gigant, L. R., Nicolás-García, M., Pignal, M., Tavares-González, F. B., Hágsater, E., SalazarChávez, G. A., Reyes-López, D., Archila-Morales, F. L., García-García, J. A., daSilva, D., Allibert, A., Solano-Campos, F., Rodríguez-Jimenes, G. C. Paniagua-Vásquez, A., Besse, P., PérezSilva, A. \& Grisoni, M. (2017). A new Vanilla species from Costa Rica closely related to V. planifolia (Orchidaceae). European Journal of Taxonomy, 284, 1-26. doi:http://dx.doi.org/10.5852/ejt.2017.284 
Biodiversity Heritage Library. (2020) A consortium of natural history and botanical libraries. Retrieved from http://www. biodiversitylibrary.org/ [accessed on 17 Oct. 2020].

Bouétard, A., Lefuvre, P., Gigant, R., Bory, S., Pignal, M., Besse, P. \& Grisoni, M. (2010). Evidence of transoceanic dispersion of the genus Vanilla based on plastid DNA phylogenetic analysis. Molecular Phylogenetics and Evolution, $55,621-630$.

Cafferty, S. \& Jarvis, C. E. (1999). Typification of Linnaean specific and varietal names in the Orchidaceae. Taxon, 48, $45-50$.

Cameron, K. M. (2003). Vanilloideae. In: A. P. Pridgeon, P. J. Cribb, M. W. Chase and F. N. Rasmussen (Eds.), Genera Orchidacearum, Volume 3. Orchidoideae (Part two) Vanilloideae (pp. 281-334). Oxford: Oxford University Press.

Cameron, K. M. (2009). On the value of nuclear and mitochondrial gene sequences for reconstructing the phylogeny of vanilloid orchids (Vanilloideae, Orchidaceae). Annals of Botany, 104, 377-385. doi:https://doi.org/10.1093/aob/ mcp024

Cameron, K. M. (2011) Vanilla Orchids, Natural History and Cultivation. London: Timber Press. 212 pp.

Catesby, M. (1729-1747). The natural history of Carolina, Florida, and the Bahama Islands: Containing the figures of birds, beasts, fishes, serpents, insects, and plants: Particularly, the forest-trees, shrubs, and other plants, not hitherto described, or very incorrectly figured by the authors. Together with their descriptions in English and French. To which, are added observations on the air, soil, and waters: With remarks upon agriculture, grain, pulse, roots, \& c. To the whole is prefixed a new and correct map of the countries treated. 2 volumes. London: Published by the author.

Clements, M. A. \& Jones, D. L. (1996). Vanilla hirsuta (Orchidaceae), a new species from Papua New Guinea. Lasianthera, $1(1), 46-49$.

Costantin, J. N. \& Bois, D. G. J. M. (1915). Botanique.-Sur troit types de Vanilles commerciales de Tahiti. Comptes Rendus Hebdomadaires des Séances de l'Académie des Sciences, 161, 196-202.

Cribb, P. J. \& Ormerod, P. (1999). Notes on Orchidaceae from the Pacific islands. Kew Bulletin, 55, 231-236.

Cribb, P.J. \& Whistler, W.A. (2011). The Orchids of Tonga, Niue, and the Cook Islands. Lankesteriana, 11(2), 99-177.

Damián, A. (2019). Vanilla yanesha (Orchidaceae), a new species of the membranaceous-leaved group from the central rainforest of Peru. Willdenowia, 49(1), 5-9.

Damián, A. \& Janovec, J. P. (2018). El género Vanilla en el Perú. Lima: Universidad Científica del Sur.

Dressler, R. L. (2005). How many orchid species? Selbyana, 26(1-2),155-158.

Dunsterville, G. C.K. \& Garay, L.A. (1959). Venezuelan Orchids Illustrated, volume 1. London: Andre Deutsch. 448 pp.

Engels, M. E., Rocha, L. C. F. \& Koch, A. K. (2020). Novidades em Vanilla Mill. (Orchidaceae) para a borda sul-amazônica, Estado de Mato Grosso, Brasil. Hoehnea, 47: e032020. http://dx.doi.org/10.1590/2236-8906-03/2020.

Felipe, F. F \& Pigozzo, C. M. (2017). Biologia reprodutiva de Vanilla bahiana Hoehne (Orchidaceae). Orquidário, 30, 3-4. Ferreira, A. W. C., de Oliveira, M. S., Silva, E. O., Campos, D. S., Pansarin, E. R. \& Guarçoni, E. A. E. (2017). Vanilla bahiana Hoehne and Vanilla pompona Schiede (Orchidaceae, Vanilloideae): two new records from Maranhão state, Brazil. Check List, 13 (6), 1131-1137. https://doi.org/10.15560/13.6.1131

Flanagan, N., Ospina-Calderón, N. H., García, L. T., Mendoza, M. \& Mateus, H. A. (2018). A new species of Vanilla (Orchidaceae) from the North West Amazon in Colombia. Phytotaxa, 364(3),250-258.

Fraga, C. N., Rodrigues Couto, D. \& Pansarin, E. R. (2017). Two new species of Vanilla (Orchidaceae) in the Brazilian Atlantic Forest. Phytotaxa, 296(1), 63-72.

Gallage, N. J. \& Møller, B. L. (2018). Vanilla: The most popular flavour. In: W. Schwab, B. M. Lange, \& M. Wüst (eds), Biotechnology of Natural Products (pp. 3-24). Switzerland: Springer.

Garay, L. A. (1978). Orchidaceae (Cypripedioideae, Orchidoideae, Neottioideae). In: G. W. Harling \& B. B. Sparre (Eds.), Flora of Ecuador, volume 9, part 225 (pp. 1-305). Göteborg \& Stockholm: University of Göteborg \& Swedish Museum of Natural History.

Garay, L. A. \& Sweet, H. R. (1974). Orchidaceae. In: Howard, R. A. (Ed.), Flora of the Lesser Antilles. Massachussets.

Garnett, S. T. \& Christidis, L. (2017). Taxonomy anarchy hampers conservation. Nature, 546, 25-27.

Geiger, D. L. (2020). Studies in Oberonia 8 (Orchidaceae: Malaxideae). Additional 24 new synonyms, a corrected spelling, and other nomenclatural matters. Blumea, 65, 188-203.

Geiger, D. L., Crain, B. J., McCormick, M. K. \& Whigham, D. F. (2020). Ten new synonyms of Oberonia equitans (G. Forst.) Mutel indicated by morphology and molecular phylogeny. Lindleyana in Orchids, 89(8), 656-667.

Givnish, T. J., Spalink, D., Ames, M., Lyon, S. P., Hunter, S. J., Zuluaga, A., Iles, W. J. D., Clements, M. A., Arroyo, M. T. K., Leebens-Mack, J., Endara, L., Kriebel, R., Neubig, K. M., Whitten, W. M., Williams, N. H. \& Cameron, K. M. (2015). Orchid phylogenomics and multiple drivers of their extraordinary diversification. Proceedings of the Royal 
Society B: Biological Sciences,282, 20151553. doi:http://dx.doi.org/10.1098/rspb.2015.1553

Global Biodiversity Information Facility. (2020). GBIF Home Page. https://www.gbif.org/

Hamer, F. (1984). Orchids of Nicaragua part 4. Icones Plantarum Tropicarum Fasc. 11. Florida: Marie Selby Botanical Garden.

Harvard University Herbaria. (2020). Retrieved from: https://huh.harvard.edu/[accessed on 17 Oct. 2020].

Hoehne, F.C. (1944). Orchidaceas novas para a flora do Brasil, dos herbários do Inst. de Botânica, Jardím Botânico, Rio de Janeiro, e comissão de lingas letegráficas, estratégicas de Mato-Grosso ao Amazonas. Arquivos de Botânica do Estado de São Paulo, 1, 125-134.

Hoehne, F. C. (1945). Orchidaceae. In: F. C. Hoehne (Ed.), Flora Brasilica, volume 12, part 2(pp. 1-389). Sao Paulo: Secretaria da Agricultura, Indústria e Comércio de Sao Paulo.

Hoehne, F. C. (1950). Algumas novidades da Flora do Brasil Austro Oriental de entre Orchidaceas e Convolvulaceas. Arquivos de Botânica do Estado de São Paulo, 2(5),105-110.

Householder, E., Janovec, J., Balarezo, A., Maceda, H., Wells, J. \& Valega, R. (2010). Diversity, natural history, and conservation of Vanilla (Orchidaceae) in amazonian wetlands of Madre de Dios, Peru. Journal of the Botanical Research Institute of Texas, 4, 227-243.

Hu, Y., Resende, M. F. R., Bombarely, A., Brym, M., Bassil, E. \& Chambers, A. H. (2019). Genomics-based diversity analysis of Vanilla species using a Vanilla planifolia draft genome and Genotyping-By-Sequencing. Scientific Reports, 9, 3416. https://doi.org/10.1038/s41598-019-40144-1

INCT - Herbário Virtual da Flora e dos Fungos. (2020). Retrieved from: http://inct.splink.org.br/ (accessed 23 Oct. 2020)

Isaac, N. J. B., Mallet, J. \& Mace, G. M. (2004). Taxonomic inflation: its influence on macroecology and conservation. Trends in Ecology \& Evolution, 19, 464-469.

Karremans, A. P. \& Davin, N. (2017) Genera Pleurothallidinarum: the era of Carl Luer. Lankesteriana, 17, I-VIII. https:// doi.org/10.15517/lank.v17i2.30273

Karremans, A. P. \& Lehmann, C. (2018). A highly threatened new species of Vanilla from CostaRica. Lindleyana, 87(45), 304-307.

Koch, A. K., Fraga, C. N., Santos, J. U. M., Ilkiu-Borges, A. L. (2013). Taxonomic notes on Vanilla (Orchidaceae) in the Brazilian Amazon, and the Description of a New Species. Systematic Botany, 38, 975-981.

Lubinsky, P., Cameron, K. M., Molina, M. C., Wong, M., Lepers-Andrzejewski, S., Gómez-Pompa, A. \& Kim, S. C. (2008). Neotropical roots of a Polynesian spice: the hybrid origin of Tahitian vanilla, Vanilla $\times$ tahitensis (Orchidaceae). American Journal of Botany, 95(8), 1040-1047.

Miller, P. (1768). The Gardeners Dictionary, 8th ed.: Vanilla no. 19. London: Printed by the author, without pagination.

Montes de Oca-Vásquez, G., Solano-Campos, F., Azofeifa-Bolaños, B., Paniagua-Vásquez, A., Vega-Baudrit, J., RuizNavarro, A., López-Mondéjar, R. \& Bastida, F. (2020). Microhabitat heterogeneity associated with Vanilla spp. and its influences on the microbial community of leaf litter and soil. Soil Ecology Letters, 2, 195-208. https://doi.org/10.1007/ s42832-020-0041-7

Moore, J. W. (1933). New and critical plants from Raiatea. Bulletin of the Bernice P. Bishop Museum, 102, 1-53.

Muséum national d'histoire naturelle: Vascular plants $(\mathrm{P})$. Retrieved from https://science.mnhn.fr/institution/mnhn/ collection/p/item/search/form [accessed on 17 Oct. 2020]

Pansarin, E. R., Aguiar, J. M. R. B. V. \& Ferreira, A. W. C. (2012). A new species of Vanilla (Orchidaceae: Vanilloideae) from Sao Paulo, Brazil. Brittonia, 64, 157-161. https://doi.org/10.1007/s12228-011-9215-z

Pansarin, E. R. \& Miranda, M. R. (2016). A new species of Vanilla (Orchidaceae: Vanilloideae) from Brazil. Phytotaxa, 267, 84-88. https://doi.org/10.11646/phytotaxa.267.1.9

Portères, R. (1951a). Nouvelles espèces de Vanilliers. Bulletin de la Société Botanique de France, 98, 92-95.

Portères, R. (1951b). Nouvelles espèces de Vanilliers (suite) Observations sur Je Vanillier de Tahiti. Bulletin de la Société Botanique de France, 98,126-127.

Portères, R. (1954). Le genre Vanilla et ses espèces. In: G. Bouriquet (Ed.), Le vanillier et la vanille dans le monde (pp. 94-290). Paris: Editions Paul Lechevailer.

Presl, C. (1830). Reliquiae Haenkeanae: seu descriptiones et icones plantarum, quas in America meridionali et boreali, in insulis Philippinis et Marianis collegit Thaddaeus Haenke. Prague: J.G. Calve. doi:https://doi.org/10.5962/bhl.title.515

Pulle, A. A. (1906). Enumeration of the vascular plants known from Surinam. Leiden: E.J. Brill.

Pupulin, F. (2012). The Orchidaceae of Ruiz \& Pavon's "Flora Peruviana et Chilensis." A taxonomic study II. Anales del Jardin Botánico de Madrid, 69(2), 143-186.

Pupulin, F. (2016). Why we have no serious alternatives but cooperative taxonomy. Lankesteriana, 16(2), 279-291. 
Pupulin, F. \& Bogarín, D. (2012). Lepanthes novae Tapantienses. Orchid Digest, 76(1), 20-29.

Pupulin, F. \& Karremans, A. P. (2017). Horichia dressleri. A new genus recorded for Costa Rica and a truly rare orchid? Lindleyana in Orchids, 86(8), 610-617.

Reflora - Herbário Virtual. (2020). Retrieved from: http://reflora.jbrj.gov.br/reflora/herbarioVirtual/ [accessed on 17 Oct. 2020]

Reichenbach, H. G. (1883). Vanilla pfaviana, n. sp. The Gardeners' Chronicle, new series, 20(504), 230.

Reveal, J. L. (2013). Identification of the plants and animals illustrated by Mark Catesby for his Natural History of Carolina,

Florida, and the Bahama Islands. Phytoneuron, 2013(6), 1-55.

Rolfe, R. A. (1895). Vanillas of commerce. Bulletin of Miscellaneous Information Kew, 104, 169-178.

Rolfe, R. A. (1896). A revision of the genus Vanilla. Journal of the Linnean Society, 32, 439-478.

Sambin, A. \& Chiron, G. (2015). Deux nouvelles espèces de Vanilla (Orchidaceae) de Guyane française. Richardiana, 15, 306-316.

Sangster, G. (2009). Increasing numbers of bird species result from taxonomic progress, not taxonomic inflation. Proceedings of the Royal Society B: Biological Sciences, 276, 3185-3191.

Schiede, C. J. W. (1829). Botanische Berichte aus Mexico, mitgetheilt vom Dr. Schiede. Linnaea, 4, 554-583.

Schlechter, R. (1920). Die Orchideen floren der südamerikanischen Kordillerenstaaten II. Colombia. Repertorium Specierum Novarum Regni Vegetabilis, Beihefte, 7, 1-301.

Sessé, M. \& Mociño, J. M. (1894). Flora Mexicana, ed.2. México D F: Oficina tipográfica de la Secretaría de fomento.

Skočdopolová, B. (1995). Historie herbářů Tadeáše Haenkeho a jejich zpracování v Preslově díle Reliquiae Haenkeanae

[History of the herbarium collections of T. Haenke, and their evaluation in Presl, Reliquiae Haenkeanae]. Zprávy Československé Botanické Společnosti, 30, 161-166.

Soto Arenas, M. A. \& Cribb, P. (2010). A new infrageneric classification and synopsis of the genus Vanilla Plum. ex Mill. (Orchidaceae: Vanillinae). Lankesteriana, 9, 355-398.

Soto Arenas, M. A. \& Dressler, R. L. (2003). Vanilla. In: B. E. Hammel, M. H. Grayum, C. Herrera \& N. Zamora (Eds.), Manual de plantas de Costa Rica. Volumen III. Monocotiledóneas (Orchidaceae-Zingiberaceae) (pp.583-587). Monographs in Systematic Botany from the Missouri Botanical Garden, 93.

Soto Arenas, M. A. \& Dressler, R. L. (2010). A revision of the Mexican and Central American species of Vanilla Plumier ex Miller with a characterization of their ITS region of the nuclear ribosomal DNA. Lankesteriana, 9, 285-354.

Silva, M. F. F. da \& Silva, J. B. F. da. (2010). Orquideas nativas da Amazonia Brasileira II. 2.ed. Rev. Belém: Museu Paraense Emilio Goeldi.

Szlachetko, D. L., Veyret, Y., Mytnik-Ejsmont, J., Sawicka, M., Rutkowski, P. \& Baranow, P. (2012). Orchids of French Guiana. Germany: A. R. G. Gantner Verlag Kornmanditgesellschaft, Ruggell.

Szlachetko, D. L., Nowak, S., Baranow, P. \& Kolanowska, M. (2016). Orchids of the Guianas (Guyana, Suriname, French Guiana) 1. Schmitten-Oberreifenberg: Koeltz Botanical Books.

The Herbarium Catalogue. (2020). Royal Botanic Gardens, Kew. Retrieved from http://www.kew.org/herbcat [accessed on 17Oct.2020].

Tropicos. (2020). Missouri Botanical Garden, Missouri, USA. Retrieved from http://www.tropicos.org/[accessed on 17 Oct. 2020].

Turland, N. J., Wiersema, J. H., Barrie, F. R., Greuter, W., Hawksworth, D. L., Herendeen, P. S., Knapp, S., Kusber., W.-H., Li, D.-Z., Marhold, K., May, T. W., McNeill, J., Monro, A. M., Prado, J., Price, M. J. \& Smith, G. F. (2018): International Code of Nomenclature for algae, fungi, and plants (Shenzhen Code) adopted by the Nineteenth International Botanical Congress Shenzhen, China, July 2017. Regnum Vegetabile, 159.

Umamaheswari, R. \& Mohanan, K. V. (2011). A study of vegetative and floral morphology of Vanilla planifolia and Vanilla $\times$ tahitensis. Journal of Non-Timber Forest Products, 18(2),95-100.

van den Berghe, E. P. \& de van den Berghe, I. G. (2008). Las orquídeas de Nicaragua, una guía de campo. REtrieved from http://www.caftadr-environment.org/spanish/outreach/publications/37_cafta_Orquideas_final.pdf. [accessed 17 July 2019].

Villanueva-Viramontes, S., Hernández-Apolinar, M., Carnevali Fernández-Concha, G., Dorantes-Euán, A., Dzib, G. R. \& Martínez-Castillo, J. (2017). Wild Vanilla planifolia and its relatives in the Mexican Yucatan Peninsula: Systematic analyses with ISSR and ITS. Botanical Sciences, 95, 169-187.

Watteyn, C., Fremout, T., Karremans, A. P., Huarcaya, R. P., Azofeifa, J. B., Reubens, B. \& Muys, B. (2020). Vanilla distribution modeling for conservation and sustainable cultivation in a joint land sparing/ sharing concept. Ecosphere, $11, \mathrm{e} 03056$. 
Weitzner,V. \& Fonseca Borrás, M. (2001). Capítulo 6. Cahuita, Limón, Costa Rica: Del conflicto a la colaboración. In: D. Buckles (Ed.), Cultivar la paz: conflicto y colaboración en el manejo de los recursos naturales (pp.137-160). Ottawa: Centro Internacional de Investigaciones para el Desarrollo.

Zachos, F. E., Apollonio, M., Bärmann, E. V., Festa-Bianchet, M., Göhlich, U., Habel, J. C., Haring, E., Kruckenhauser, L., Lovari, S., McDevitt, A. D., Pertoldi, C. (2013). Species inflation and taxonomic artefacts- A critical comment on recent trends in mammalian classification. Mammalian Biology, 78, 1-6. 
